\title{
LATE QUATERNARY LANDSCAPE DYNAMICS IN THE PODOCARPUS NATIONAL PARK REGION IN THE SOUTHEASTERN ANDES OF ECUADOR
}

\author{
Dissertation \\ zur Erlangung des mathematisch-naturwissenschaftlichen Doktorgrades \\ "Doctor rerum naturalium" \\ der Georg-August-Universität Göttingen
}

vorgelegt von

Dipl. Umweltbiologin (FH)

Corinna Brunschön

aus Hannover

Göttingen 2010 
Referent: Prof. Dr. Hermann Behling Koreferent: Prof. Dr. Michael Kessler

Tag der mündlichen Prüfung: 09.08.2010 
Für meine Eltern 


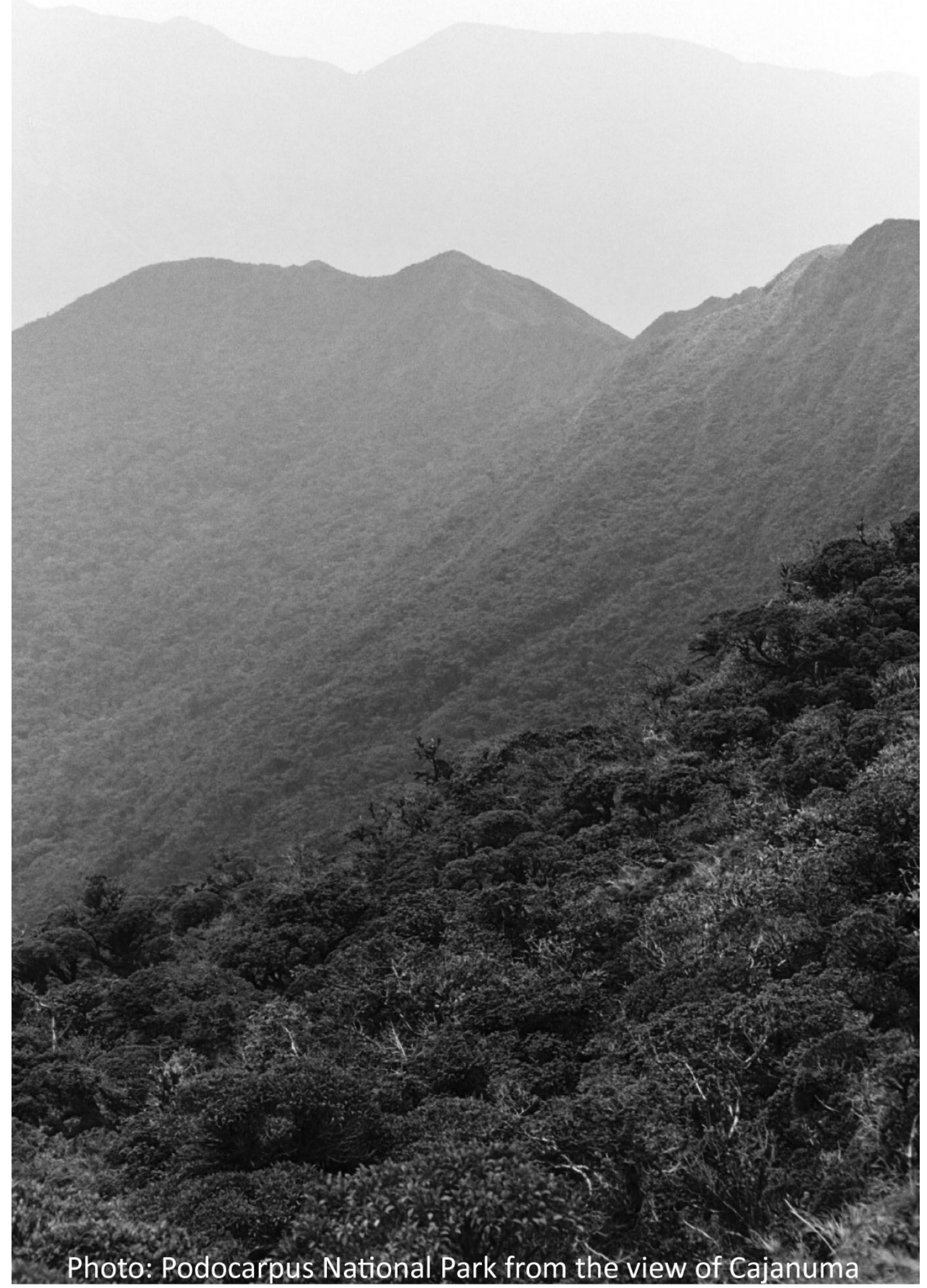




\section{Contents}

\begin{tabular}{ll}
\hline Acknowledgements & 1
\end{tabular}

\begin{tabular}{ll}
\hline Summary & 3
\end{tabular}

\begin{tabular}{ll}
\hline Resumen & 4
\end{tabular}

\begin{tabular}{ll}
\hline Zusammenfassung & 5
\end{tabular}

1. General Introduction $\quad 7$

$\begin{array}{lll}\text { 1.1. Background - Research on a tropical mountain ecosystem of Ecuador } & 7\end{array}$

1.2. Palynological and Palaeoecological research in the northern tropical Andes - state of knowledge . . . . . . . . . . . . . . 8

1.3. General objectives and outline of chapters . . . . . . . . . . . . . . . 14

1.4. Study region and pollen record sites - an overview . . . . . . . . . . . 16

1.5. Palynology - some general aspects of methods and applications . . . . 21

1.6. References . . . . . . . . . . . . . . . . 24

2. Late Quaternary environmental history of Cerro Toledo 31

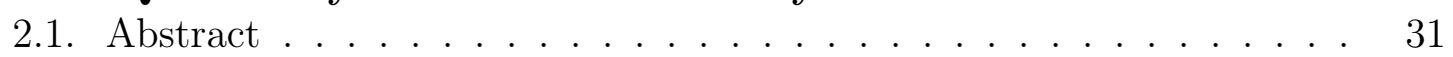

2.2. Introduction . . . . . . . . . . . . . . . . . . . . . 32

2.3. Study site . . . . . . . . . . . . . . . . . . . . . . 32

2.4. Methods . . . . . . . . . . . . . . . . . . . . . . . . . . . . . . . . 35

2.5. Results . . . . . . . . . . . . . . . . . . . . . . . 35

2.6. Interpretation and discussion . . . . . . . . . . . . . . . . . . . . . . . . . . . . . . 55

2.7. Conclusions . . . . . . . . . . . . . . . . . 51

2.8. Acknowledgements . . . . . . . . . . . . . . . 51

2.9. References . . . . . . . . . . . . . . . . . . . . . . . . . 51

\begin{tabular}{ll}
\hline 3. Subrecent environmental history of Laguna Campana & 57
\end{tabular}

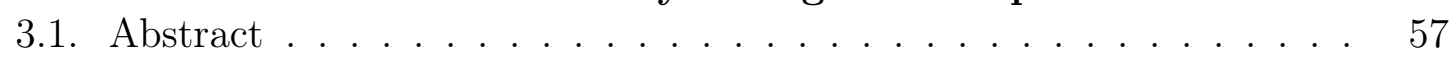

3.2. Introduction . . . . . . . . . . . . . . . . . . 58

3.3. Study site . . . . . . . . . . . . . . . . . . . . . . . . . . . 58

3.4. Materials and methods . . . . . . . . . . . . . . . . . . . 61

3.5. Results . . . . . . . . . . . . . . . . . . . 63

3.6. Interpretation and discussion . . . . . . . . . . . . . . . . 71

3.7. Conclusions . . . . . . . . . . . . . . . . . . . 77

3.8. Acknowledgements . . . . . . . . . . . . . . . . . . . . . 78

3.9. References . . . . . . . . . . . . . . . . . . . . . . . . . . 78 
4. Late Quaternary upper forest line and vegetation changes in the $\begin{array}{lr}\text { PNP region } & \mathbf{8 5}\end{array}$

4.1. Abstract . . . . . . . . . . . . . . . . . . . . . . 85

4.2. Introduction . . . . . . . . . . . . . . . . . . . . 86

4.3. Environmental settings of the study area . . . . . . . . . . . . . . 87

4.4. Material and Methods . . . . . . . . . . . . . . . . . . . 91

4.5. Description of fossil pollen records . . . . . . . . . . . . . . . . 95

4.6. Environmental reconstruction and visualization . . . . . . . . . . . 97

4.7. Discussion . . . . . . . . . . . . . . . . . . . . . . . . . . . . 104

4.8. Conclusions . . . . . . . . . . . . . . . . . . . . . . . . . . . . . . . . 109

4.9. Acknowledgements . . . . . . . . . . . . . . . . . . . . 110

4.10. References . . . . . . . . . . . . . . . . . . . . . . . 111

\begin{tabular}{ll}
\hline . Vegetation/modern pollen rain relationship & 119
\end{tabular}

5.1. Abstract . . . . . . . . . . . . . . . . . . . . 119

5.2. Introduction . . . . . . . . . . . . . . . . . . . 120

5.3. Site description . . . . . . . . . . . . . . . . . . . . 121

5.4. Materials and methods . . . . . . . . . . . . . . . . . . . 124

5.5. Results . . . . . . . . . . . . . . . . . . . . . . . . 129

5.6. Interpretation and discussion . . . . . . . . . . . . . . . . 131

5.7. Summary and conclusions . . . . . . . . . . . . . . . . . . 138

5.8. Acknowledgements . . . . . . . . . . . . . . . . . . . . . . . . . 138

5.9. References . . . . . . . . . . . . . . . . . . . . . . . . . . . . . 139

6. Supplementary study on palynological richness vs. plant diversity 143

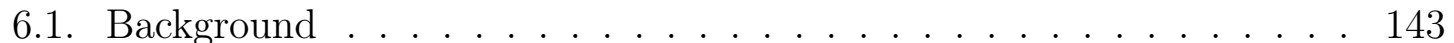

6.2. Data basis for diversity measures . . . . . . . . . . . . . . . . . . . 145

6.3. Results . . . . . . . . . . . . . . . . . . . . 146

6.4. Discussion . . . . . . . . . . . . . . . . . . . . . 147

6.5. Consequences for future research . . . . . . . . . . . . 150

6.6. Closing remarks . . . . . . . . . . . . . . . . . . . . . . . 152

6.7. References . . . . . . . . . . . . . . . . . . . . . . . . 154

\begin{tabular}{ll}
\hline 7. Synthesis & 157
\end{tabular}

\begin{tabular}{ll}
\hline Appendices & 162
\end{tabular}

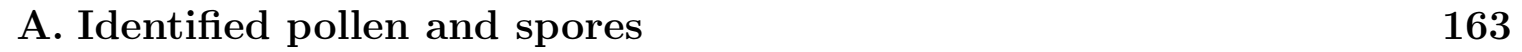

\begin{tabular}{ll}
\hline B. Complete pollen records & 187
\end{tabular} 


\section{ACKNOWLEDGEMENTS}

The last three years spent working on my $\mathrm{PhD}$ thesis has been an intensive time and filled with new experiences, learning and growing while facing new challenges. It would never have been possible for me to successfully persevere without the many following people I want to thank at this point.

First of all, my thanks go to Hermann Behling not only for his kind offer for me to work on this thesis but also for his support during three years of research at the Department of Palynology and Climate Dynamics. Many thanks also to Michael Kessler for co-advising and to Torsten Haberzettl, Antoine Cleef, Thomas Giesecke, Anne Brigitte Nielsen and Gerald Islebe for the scientific discussions and their help with statistics or interpretations. I also wish to thank Jürgen Homeier and KarlHeinz Diertl for making their vegetation data available to me. I kindly thank Susana León-Yánez for providing access to the QCA herbarium and for her support during the student course at the PUCE. Thanks to Patricio Crespo for his guidance during a field survey. Thank you to all the staff members of the ECSF, especially Jörg Zeilinger and the drivers Abrahan and Tati, for the comfortable accommodation, logistic support and practical help during our field work. Thank you to the entire staff of the Department of Palynology and Climate Dynamics for their collegiality. Special thanks go to my fine colleagues and friends Fernando Rodríguez, Vivian JeskePieruschka, Barbara Hermanowski, Lisa Schüler, Nele Jantz, Isabelle Matthias and Andrea Villota for their company, high-load carrying capacity, active help and good moods they shared with me during the past few years. I additionally wish to thank my Ecuadorian sister Carolina as well as Fernando and EcoCiencia for providing me a place to live and work whenever I am in Quito. I am very thankful to Dietmar Zacharias for making personal contact with Hermann Behling and in particular to my family and friends supporting and encouraging me at all times: Brunhilde, Horst (in loving memory), Florian, Thanin, Kirsten, Christian, Anna, Isabell, Sandra, Claudia, Katja, Simone, Melanie and David. Finally, I want to express my gratitude to the "Deutsche Forschungsgemeinschaft" (DFG) for the financial support. 



\section{Summary}

The southeastern Ecuadorian Andes belong to the tropical eastern Andes and represent one of the global centers of vascular plant diversity. They are one of the most biodiverse regions on earth. Despite the immense value and importance of the ecosystems existing here, we must confront the endangerment of these largely unexplored habitats. Additionally, palaeoenvironmental studies are rarely implemented, even though past processes play a major role in the development of ecosystems and biodiversity. In the present study, we carry out an investigation of late Quaternary vegetation, climate and fire dynamics in order to gain a deeper understanding of past environmental changes in the Podocarpus National Park (PNP) region in the southeastern Andes of Ecuador. The results contribute essential background information for conservation strategies in the PNP area and provide a further step towards a better assessment of the ecosystem's responses to future global change.

Palynological and multi-proxy analyses of three sediment records are used to reconstruct past vegetation dynamics and to reveal the influencing factors. The combination of several available pollen records and the establishment of a rule of thumb for vertical shifts of the upper forest line (UFL) facilitated the first regional environmental reconstruction and visualization for an area of the PNP since the last glacial maximum (LGM). The implementation of multivariate data analysis of modern pollen data further extends our knowledge of the representation of vegetation patterns in pollen data. Additionally, comparisons between plant diversity and palynological richness (pollen and spore diversity) provide initial insights into how pollen diversity data reflects vegetation diversity in a highly diverse area.

The analysis of the record from Laguna Campana, located west of the PNP, yields a detailed environmental reconstruction for the study site over the past ca. 500 years and reveals continuous anthropogenic impact, which affected local vegetation development and biodiversity. Two pollen records from the Cerro Toledo area in the southern PNP reach back ca. 20,000 years ago and the analysis of these pollen records indicates changes in vegetation distribution and composition primarily due to past climate dynamics. The regional environmental reconstruction shows that during the LGM the UFL was located several hundred meters lower than its current level and that páramo vegetation widely dominated the landscape of the study region due to cold and wet climatic conditions. Rising temperatures since late glacial times led to a gradual shift of forest upslope. The results of this study clearly show that overall similarities between sites contrast with local differences in late Quaternary environmental history in the northern Andes and even within the study region. The high variety is caused by the complex and heterogeneous Andean habitats as well as by site-specific relevance and interactions of natural and anthropogenic factors determining vegetation patterns and developments. Modern pollen data analysis shows that vegetation patterns are generally well reflected by pollen deposition data, which contributes to the interpretative basis of the fossil pollen records. Finally, this study suggests that palynological richness as a measure for vegetation diversity in the research area is complex, and future investigations on this topic are necessary to elaborate on the preliminary results obtained so far. 


\section{Resumen}

El sureste de los Andes Ecuatorianos pertenece a los Andes tropicales orientales, que representa uno de los centros de diversidad de plantas vasculares y de mayor biodiversidad sobre la tierra. A pesar del gran valor e importancia de estos ecosistemas, se debe hacer frente a hábitats inexplotados y amenazados. Estudios paleoambientales son muy escasos, a pesar de que los procesos en el pasado juegan un papel importante en el desarrollo de los ecosistemas y de la diversidad. En el presente estudio se presentan investigaciones sobre la dinámica de la vegetación, el clima y el fuego en el Cuaternario tardío para obtener una mejor comprensión de los cambios ambientales en el pasado en la región del Parque Nacional Podocarpus (PNP) al sureste de los Andes del Ecuador. Esta información contribuye a desarrollar estrategias de conservación y aporta a un mejor entendimiento de la respuesta futura de los ecosistemas al cambio global.

Estudios palinológicos y multi-proxy de tres sedimentos fueron usados para reconstruir la dinámica de la vegetación en el pasado y los factores de influencia. La combinación de registros de polen disponibles y el establecimiento de una regla general sobre el cambio altitudinal de la línea del bosque, facilita una primera reconstrucción y visualización regional del medio ambiente de una zona del PNP desde el último período glacial máximo (LGM). Análisis multivariado de datos de polen actual es implementado para ampliar nuestro conocimiento de la representación de los patrones de la vegetación con base en datos de polen. Comparaciones entre la diversidad de plantas y la riqueza palinológica, dan las primeras ideas sobre como datos de polen reflejan la diversidad de la vegetación en un área altamente diversa.

El análisis de sedimentos de Laguna Campana al occidente del PNP, facilita la reconstrucción del medio ambiente de este sitio para los últimos 500 años y revela el impacto antropogénico permanente que afectó el desarrollo de la vegetación y de la biodiversidad. En dos registros de polen del área de Cerro Toledo al sur del PNP, que alcanzan los últimos 20,000 años, los resultados indican cambios en la distribución y composición de la vegetación principalmente debido a cambios climáticos. La reconstrucción regional muestra que durante el LGM el límite del bosque estuvo ubicado varios cientos de metros más bajo de lo que es actualmente y la vegetación de páramo dominaba el área del PNP, influenciado por condiciones climáticas frías y húmedas. Con el incremento de la temperatura a partir del último período glacial el bosque cambio gradualmente hacia arriba. Los resultados de este estudio muestran que similaridades en general contrastan con diferencias a nivel local en la historia del medio ambiente en el Cuaternario Tardío en el norte de los Andes, inclusive dentro del área de estudio. La alta variedad es causada por el complejo y heterogéneo hábitat Andino así como también por la relevancia e interacción a nivel del sitio de factores naturales y antropogénicos que determinan los patrones de la vegetación y su desarrollo. Análisis de polen actual muestra que los patrones de la vegetación son bien reflejados por datos de la deposición del polen, que contribuye a la base de la interpretación del registro de polen fósil. Se sugiere que la riqueza de polen como medida de la diversidad de la vegetación en el área de estudio es compleja y que futuras investigaciones sobre este tema son necesarias mejorar los resultados preliminares obtenidos hasta ahora. 


\section{Zusammenfassung}

Die Ostkordillere der südecuadorianischen Anden gehört zu den tropischen OstAnden, die weltweit zu den Gebieten mit höchster Biodiversität und größtem Artenreichtum an Gefäßpflanzen zählen. Ungeachtet des besonderen Werts und der Bedeutung hier vorkommender Ökosysteme, sind diese Lebensräume gefährdet und bislang unzureichend erforscht. Auch paläoökologische Studien sind hier selten, obwohl vergangene Prozesse die Entwicklung heutiger Ökosysteme und Diversität grundlegend bestimmt haben. Im Rahmen dieser Arbeit wurden die zeitliche Dynamik von Vegetation, Klima und Feuer im Spätquartär erforscht, um ein besseres Verständnis vergangener Umweltveränderungen im Gebiet des Podocarpus Nationalparks (PNP) in den südöstlichen Anden Ecuadors zu erlangen. Die Ergebnisse liefern wichtige Informationen für naturschutzfachliche Maßnahmen im PNP und ermöglichen bessere Einschätzungen, wie Ökosysteme zukünftig auf den globalen Klimawandel reagieren werden.

Palynologische und Multiproxy Analysen dreier Sedimentkerne wurden durchgeführt, um vergangene Vegetationsveränderungen zu rekonstruieren und die darauf einflussnehmenden Faktoren zu identifizieren. Verschiedene palynologische Studien und die Abschätzung von Höhenverschiebungen der Waldgrenze ermöglichen eine erste regionale Umweltrekonstruktion und Visualisierung in einem Bereich des PNP seit dem letzten glazialen Maximum (LGM). Für eine nähere Betrachtung des Verhältnisses rezenter Pollendaten zu Vegetationsstrukturen innerhalb des diversen Untersuchungsgebiets, wurde Multivariate Datenanalyse angewendet. Zusätzlich wurde die Diversität verglichen, die mittels Pollenfallen und Vegetationsaufnahmen erfasst wurde.

Die Analyse des Seesediments der Laguna Campana, westlich des PNP, ermöglicht eine detaillierte Rekonstruktion der letzten 500 Jahre und zeigt stetigen anthropogenen Einfluss und dessen Auswirkungen auf lokale Vegetationsentwicklung und Diversität. Zwei Untersuchungen bei Cerro Toledo im südlichen PNP zeigen Veränderungen in Verbreitung und Zusammensetzung der Vegetation unter variierenden klimatischen Gegebenheiten über die letzten ca. 20,000 Jahre. Die regionale Rekonstruktion verdeutlicht, dass die Waldgrenze im LGM mehrere hundert Meter tiefer lag als heute, und dass Páramo das Landschaftsbild des PNP weitreichend bestimmte während kaltes und feuchtes Klima vorherrschte. Mit ansteigenden Temperaturen seit dem Spätglazial hat sich die Waldgrenze sukzessiv in höhere Lagen verschoben. Die Ergebnisse dieser Arbeit zeigen deutlich, dass übergeordnete Ähnlichkeiten in der spätquartären Umweltgeschichte vielen lokalen Unterschieden innerhalb der nördlichen Anden und sogar im Gebiet des PNP gegenüberstehen. Die Differenziertheit wird mit der extremen Vielfalt und Heterogenität andiner Lebensräume, sowie den standortspezifischen natürlichen und anthropogenen Faktoren und deren Interaktion begründet, die Vegetationsstrukturen und deren Entwicklung bestimmen. Die Analyse rezenter Pollendaten zeigt generell eine gute Repräsentanz der Vegetationsstrukturen innerhalb dieser Daten, was für die Interpretation fossiler Pol-

lendiagramme wichtig ist. Für die Erfassung der Vegetationsdiversität anhand von Pollendaten ist eine hohe Komplexität angedeutet, was nähere Studien hierzu für weiterführende Forschungsansätze unumgänglich macht. 



\section{Chapter 1.}

\section{General Introduction}

\subsection{Background - Research on a tropical mountain ecosystem of Ecuador}

The Ecuadorian Andes are among the most diverse regions on earth. Situated in the tropical eastern Andes biodiversity hotspot, they represent one of the five global centers of vascular plant diversity with $>5,000$ species per $10,000 \mathrm{~km}^{2}$ (Barthlott et al., 2007). In particular, evergreen and semi-deciduous tropical mountain forests (synonymous terms: montane (rain) forests), contribute to this extraordinarily high level of biodiversity (Richter, 2008). Despite the significance of these mountain ecosystems in terms of biodiversity, they generally receive less scientific attention than tropical forests of the lowlands (Beck et al., 2008a). Moreover, Ecuador suffers the highest annual deforestation rate among South American countries (ca. 198,000 ha year ${ }^{-1}$ between 1990 and 2005, FAO 2005), with mountain forests particularly undergoing serious degradation (Bendix and Beck, 2009). Because of the endangered and relatively unexplored status of these valuable ecosystems, Ecuadorian and German research groups are carrying out comprehensive investigations of tropical mountain forest located in the eastern range of the Ecuadorian Andes. Investigations began in the late 1990s, and the DFG (Deutsche Forschungsgemeinschaft) research unit 402 ("Functionality in a Tropical Mountain Rainforest: Diversity, Dynamic Processes and Utilization Potentials under Ecosystem Perspectives") brought together and coordinated various working groups since 2000. In 2007, the new DFG research unit 816 ("Biodiversity and Sustainable Management of a Megadiverse Mountain Ecosystem in South Ecuador") was launched to continue investigations in the same area focusing on ecosystem functioning and sustainable land use management strategies in a biodiversity hotspot of the south Ecuadorian Andes. Studies are still ongoing within this research unit and will proceed at least until 2013.

Within the research unit's wider study region of the southeastern Ecuadorian Andes, investigations focus lies primarily on a core area of about $11.2 \mathrm{~km}^{2}$ known as the Reserva Biológica San Francisco (RBSF). This area is located in the Podocarpus National Park (PNP), which is the southernmost protected area in Ecuador (Fig. 1.1 and 1.2). Investigations have shown that even this small area of the RBSF is representative of the global tropical eastern Andes hotspot of plant diversity (Beck and Richter, 2008). Several different factors are responsible for triggering this area's outstanding biodiversity. Besides several meso- and microscale factors (e.g. climatic, geologic, orographic and edaphic conditions as well as natural and anthropogenic disturbance regimes), the environmental history plays an important role in the devel- 
opment of the current plant diversity pattern (Broecker, 1997; Churchill et al., 1995; Richter et al., 2009).

While present ecosystems are the result of past processes, few palynological investigations have been carried out in the biodiversity hotspot of the Ecuadorian Andes. This was one of the motives for investigating late Quaternary landscape dynamics in the wider area of the PNP region, such as changes in vegetation, biodiversity, climate, fire and land use. The reconstruction and understanding of past vegetation and climate changes as well as of human impact enhance our knowledge of how past processes have influenced ecosystem dynamics and the development of the outstanding diversity in the study region. This is also important within the context of future global change and the for management and conservation strategies. The scientific community, and particularly the entire DFG research unit, will be interested in the results of this study in order to better understand the functions of the investigated tropical mountain ecosystems and their reaction to environmental changes on the local and regional scales.

Comprehensive palynological studies began in 2005 (Niemann, 2008) as part of the former DFG research unit FOR 402. These investigations continued during the first phase (2007-2010) of the new research unit FOR 816 under the subproject "Reconstruction and modelling of late Quaternary and modern landscape dynamics (vegetation, biodiversity, climate, fire, land use) in the PNP and neighbouring regions in Ecuador" and provided the framework for the present dissertation. Ongoing and future palynological studies (2010-2013) will enlarge these investigations.

\subsection{Palynological and Palaeoecological research in the northern tropical Andes - state of knowledge}

\section{Investigation efforts}

Palaeoecological studies in Andean mountain forests are generally thinly scattered because of steep slopes and scarcity of natural archives in this region (Bush et al., 2007). In the northern tropical Andes region, several investigated areas in Colombia (e.g. Berrio et al., 2002; Hooghiemstra and van der Hammen, 1993; van der Hammen and Hooghiemstra, 2003; Vélez et al., 2006; Wille et al., 2001) and Peru (e.g. Chepstow-Lusty, 2003; Bush et al., 2005; Hansen and Rodbell, 1995; Hansen et al., 1995; Paduano et al., 2003) contrast with very few palynological records in the Ecuadorian Andes (Colinvaux et al., 1997; Hansen et al., 2003; Fig. 1.1). Some more recent studies on upper forest line (UFL) changes in northern Ecuador contributed to the Holocene environmental history of the northern Ecuadorian Andes (Bakker et al., 2008; Di Pasquale et al., 2008; Wille et al., 2002; Fig. 1.1). However, palaeoecological research in Ecuador concentrated mainly on the Amazon basin (e.g. Bush and Colinvaux, 1988; Bush et al., 1990; Colinvaux et al., 1988a; Liu and Colinvaux, 1985; Weng et al., 2002; Fig. 1.1), and only one study is available from the inter-Andean Plateau (Colinvaux et al., 1988b; Fig. 1.1).

Investigations in the southeastern Ecuadorian Andes did not include palynological 


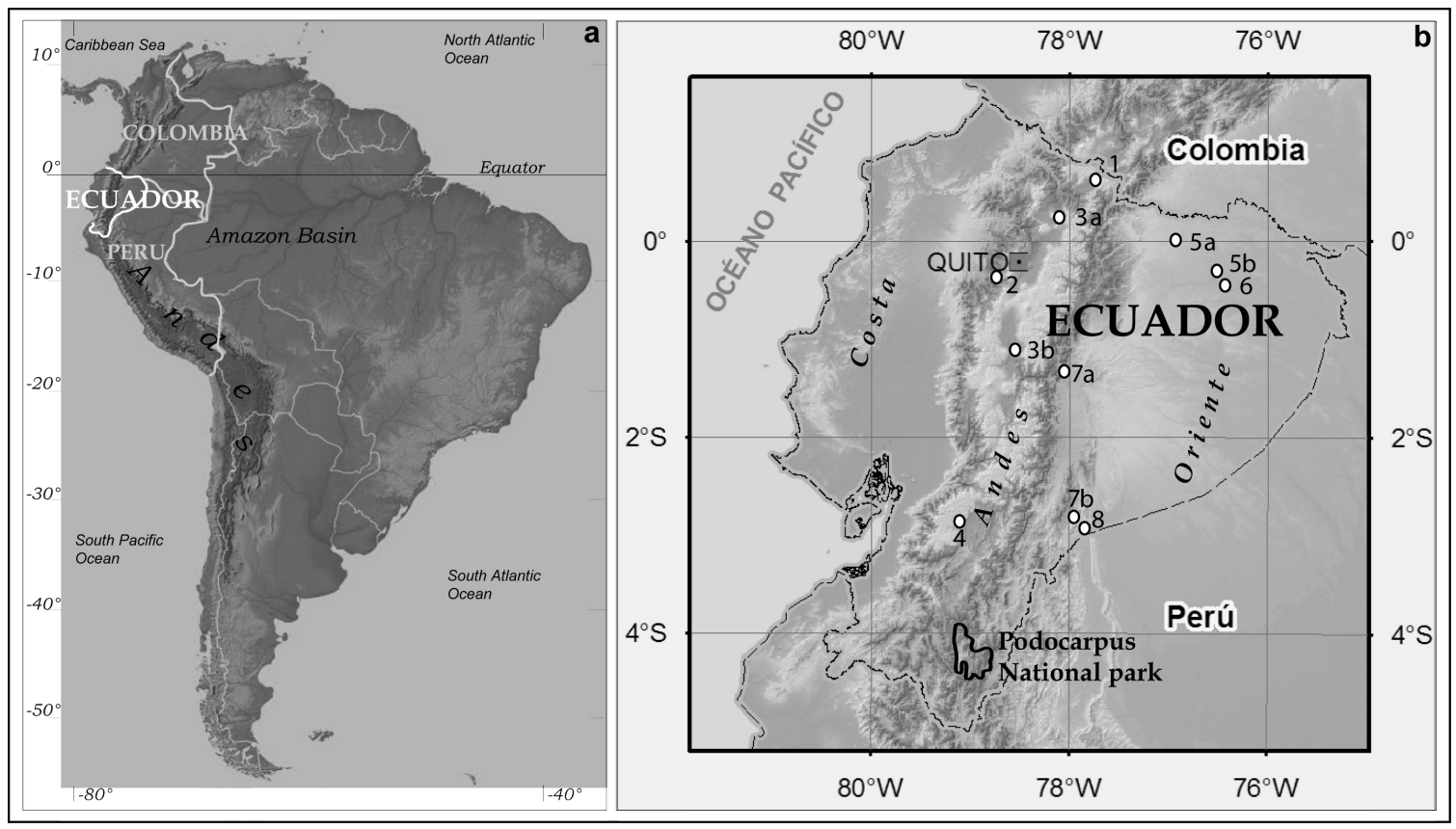

Figure 1.1. Maps showing (a) the location of Ecuador, Colombia and Peru within the region of the tropical Andes in South America ${ }^{1}$ and (b) the Podocarpus National Park (PNP) in the southeastern Ecuadorian Andes, which is the area under investigation in this study. Other palynological study sites in the Andes and Amazon basin of Ecuador are shown by white circles: (1) Bakker et al., 2008/Di Pasquale et al., 2008; (2) Wille et al., 2002; (3 a/b) Colinvaux et al., 1988b; (4) Colinvaux et al., 1997/Hansen et al., 2003; (5 a/b) Colinvaux et al., 1988a; (6) Weng et al., 2002; (7 a) Bush et al., 1990/Liu and Colinvaux, 1985; (7 b) Bush et al., 1990; (8) Bush and Colinvaux, 1988.

research until 2005, when the above mentioned subproject of the DFG research unit began to focus on palaeoenvironmental research in the wider region of the PNP (Fig. 1.1). To date, altogether eleven bog and lake cores as well as soil monoliths from the northern and central PNP area (Fig. 1.2, Table 1.1, site: 3, 4 a/b, 5 a-c, 6 a-c, $7,8)$ were analyzed and have been used to reconstruct late Quaternary vegetation, fire and climate dynamics (Niemann and Behling, 2007, 2009, 2010; Niemann et al., 2009; Rodríguez and Behling, 2010). Additional studies of a lake core in Loja (Matthias, 2008; Fig. 1.2, Table 1.1, site: 9) and some soil samples (Niemann, 2008) focused on the settlement history and past human impact in the study area. These studies are now amplified by analyses of three more pollen records conducted within the present study (Fig. 1.2, Table 1.1, site: $1 \mathrm{a} / \mathrm{b}, 2$ ). Additionally, new studies on the relationship of modern pollen rain and vegetation undertaken in this thesis enhance the interpretative basis for the fossil pollen records (Niemann et al., 2010; Fig. 1.2, Table 1.1, site: ECSF/RBSF). Studies of pollen records from sites further south near the Peruvian border and northwards near the city Cuenca are currently underway (not listed). These will permit a more extensive regional integration of the palaeoenvironmental history of PNP area.

\footnotetext{
1 map source: http://geology.com/press-release/age-of-the-andes-mountains/andes-mountains-map.jpg [15.03.2010]
} 


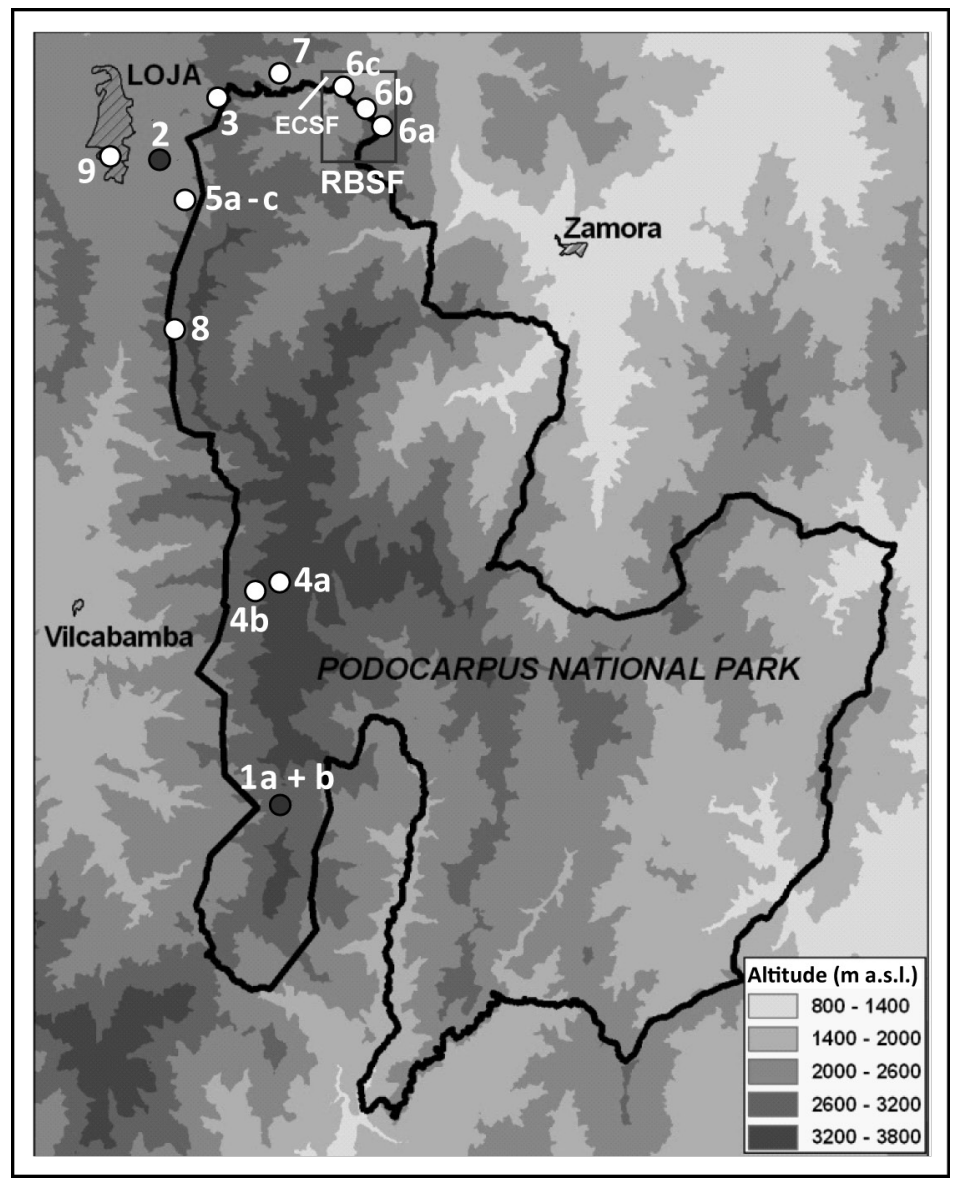

Figure 1.2. Topographic map of the Podocarpus National Park with locations of the Reserva Biológica San Francisco (RBSF), the Estacion Científica San Francisco (ECSF) and the fossil pollen record sites within the region: $(1 \mathrm{a} / \mathrm{b})$ Cerro Toledo $(\mathrm{CT} / \mathrm{CTB}),(2)$ Laguna Campana, (3) El Tiro, (4 a) Laguna Rabadilla de Vaca, (4 b) Rabadilla de Vaca mire, (5 a/b/c) Cocha Caranga, (6 a) ECSF-Cerro del Consuelo, (6 b) ECSF-Refugio, (6 c) ECSF-T2/250, (7) Laguna Zurita, (8) Valle Pequeño (Cajanuma), (9) Laguna Daniel Alvarez. Pollen records sites displayed by gray points were analyzed in this study; white points indicate pollen record sites of previous studies. Detailed information on the pollen record locations is listed in Table 1.1 
Table 1.1. Pollen record sites within the Podocarpus National Park region analyzed in this study (site: $1 \mathrm{a} / \mathrm{b}, 2)$ and previous investigations.

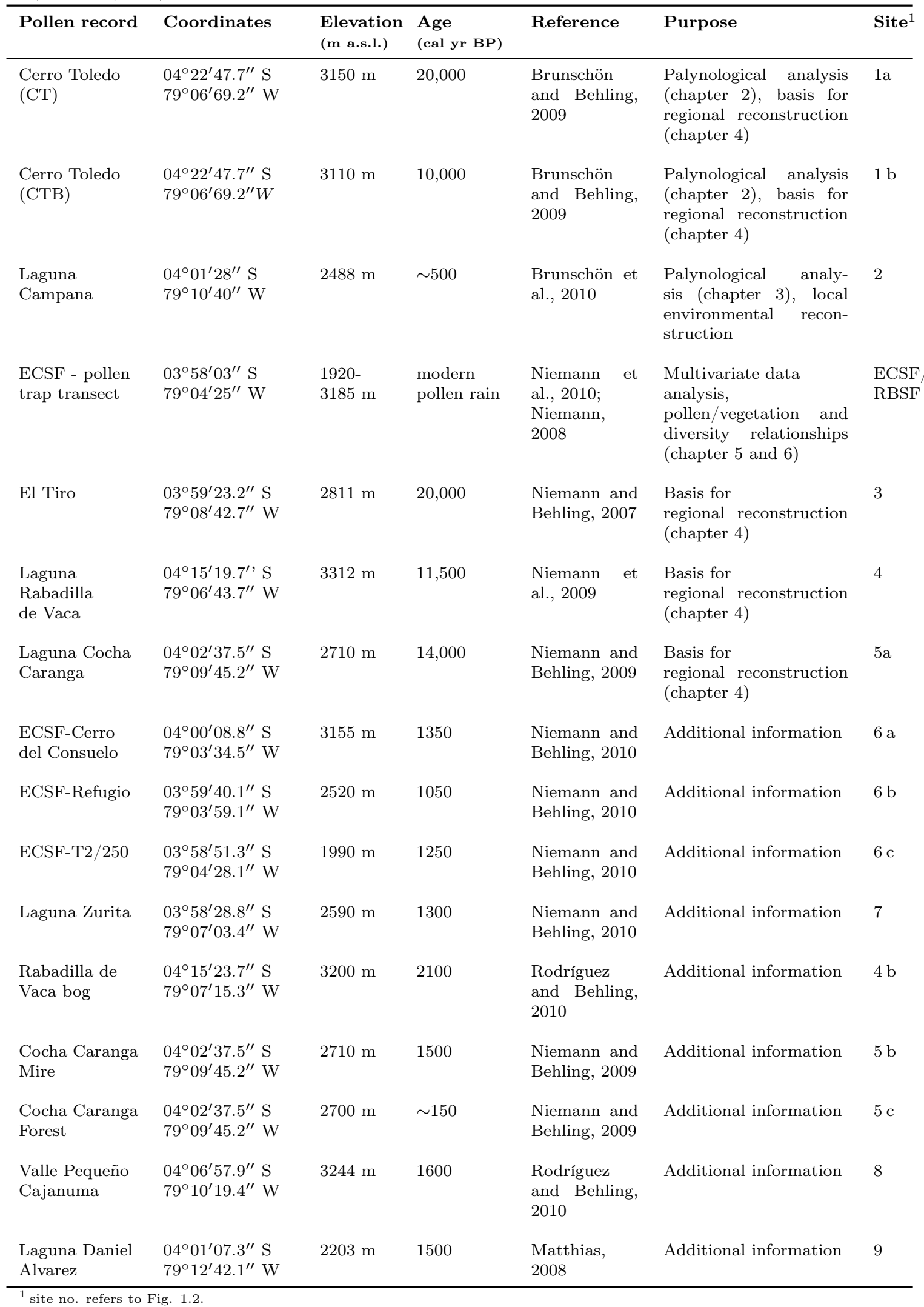




\section{Synthesis of late Quaternary vegetation, climate and fire history}

Several records in the Colombian and Peruvian Andes indicate the presence of cooler or colder climates and drier conditions during the late Pleistocene (ca. 20,00010,000 yr BP) than later (Bush et al., 2005; Hansen and Rodbell, 1995; Hansen et al., 1994; Vélez et al., 2006). For the last glacial maximum (LGM), temperatures for the Colombian Andes were estimated to be ca. $6-8{ }^{\circ} \mathrm{C}$ lower than today. Accordingly, the distribution limits of mountain forests at this time were estimated to be situated at approximate 800-1400 m lower elevations than at present (Wille et al., 2001; Hooghiemstra and van der Hammen, 1993; van der Hammen and Hooghiemstra, 2003). Comparable results were seen in studies of the Ecuadorian Amazon region (Bush et al., 1990; Liu and Colinvaux, 1985). Here, a temperature depression of $7.5^{\circ} \mathrm{C}$ was estimated for the last glacial period between ca. 33,000-30,000 yr BP. Hansen et al. (2003) showed that a cooler but moister climate than today existed at the end of last glacial times (ca. 17,000-11,000 cal yr BP) in the páramo of the southwestern Ecuadoran Andes. Similarly, cooler climates than at present are indicated by the occurrence of treeless vegetation during glacial times at a site in the southern Ecuadorian Andes, which today is dominated by Andean forest (Colinvaux et al., 1997). Climate conditions in the inter-Andean Plateau of northern Ecuador were probably drier during the late glacial period than during Holocene times, a result of influences from the Eastern Pacific (Colinvaux et al., 1988b). However, other sites of the tropical Andes also show connectivity with climate patterns of the Amazon basin (e.g. Baker et al., 2001; Heine, 2000). Assumptions of drier conditions during the LGM in the tropical Andes and lowlands (Heine, 2000) contrast with indications of wetter conditions in the Altiplano of Peru and Bolivia and much of the Amazon basin (Baker et al., 2001). With the onset of the Holocene (ca. 11,500 cal yr BP), most investigations in Peru (Bush et al., 2005; Hansen and Rodbell, 1995; Hansen et al., 1994) indicate an increase in temperature and precipitation, which caused an expansion of mountain forest into higher elevations and a partial replacement of treeless páramo or puna vegetation. This was also the case for the Cajas National Park in the southwestern Ecuadorian Andes (Hansen et al., 2003). An earlier forest advancement, that took place in the late glacial period, was indicated for a site in south Ecuador (Colinvaux et al., 1988b) and in the eastern Cordillera of Colombia (Hoogiemstra and van der Hammen, 1993). Early Holocene (ca. 10,000-6000 yr BP) conditions in Peru were consistently recorded as the thermal optimum warm event, which facilitated forest expansion. During this time, alternating wetter and drier phases occurred (Bush et al., 2005; Hansen and Rodbell, 1995; Hansen et al., 1994). Likewise, reconstructions for the early Holocene showed warmer climates in the southwestern Ecuadorian Andes than at present (Hansen et al., 2003), and studies in the eastern Andes of Colombia showed very humid conditions (Vélez et al., 2006). During the mid-Holocene (ca. 6000-4000 yr BP), drier conditions and forest declines were recorded in the Peruvian Andes (Hansen and Rodbell, 1995; Hansen et al., 1994) and in the eastern Andes of Colombia (Vélez et al., 2006). The late Holocene (after ca. 4000 yr BP) saw generally moister climatic conditions than before in southwestern Ecuador (Hansen et al., 2003). More detailed studies in the central Peruvian 
highlands showed declining temperatures between 3000 and $1000 \mathrm{yr} \mathrm{BP}$, these were followed by warmer and moister conditions that extended until today (Hansen et al., 1994).

Low fire frequency during late glacial times and increasing fire occurrence during the Holocene were recorded in southwestern Ecuador (Hansen et al., 2003). Fires have occurred at a site in northern Ecuador at least since the Pleistocene-Holocene transition (ca. 13,000 cal yr BP). Rather than causing large-scale destruction of Andean forest, these fires merely prevented forest expansion into the páramo (Di Pasquale et al., 2008). From Pleistocene until mid-Holocene times, fires can often be explained as a result of drier climate. Fires are not generally attributed to be a feature of human influence on the landscape until direct evidence of anthropogenic impact is found in pollen records (Wille et al., 2002; Hansen et al., 2003; Bush et al., 2005). One study in the eastern Peruvian Andes suggested that human activities rather than climate are responsible for controlling vegetation development after $4000 \mathrm{yr}$ BP (Hansen and Rodbell, 1995). However, humans first began to appear in South America during the late Pleistocene period ca. 13,000-11,000 yr BP (Silverman and Isbell, 2008). Nevertheless, it is often difficult to make a distinction between natural and anthropogenic fires (see Di Pasquale et al., 2008).

Studies in the transition zone between páramo and mountain forest provide detailed insights into UFL changes during the Holocene in northern Ecuador. Reconstructions suggested oscillations of several hundred meters, but during the last ca. 6000 years the UFL apparently was never or only slightly higher than at present (Bakker et al., 2008; Di Pasquale et al., 2008; Wille et al., 2002).

So far, investigations in the northern and central PNP area in southeastern Ecuador indicate that the late Pleistocene (ca. 21,000-11,500 cal yr BP) here was a cold but moist period with a wide distribution of páramo vegetation (Niemann, 2008; Niemann and Behling, 2007). During this time, distribution limits of mountain forest were markedly lower than at present (Niemann and Behling, 2007), but altitudinal ranges remain uncertain. At the study site of Laguna Cocha Caranga (Fig. 1.2. Table 1.1, site: 5 a), located on the drier western slopes, an expansion of mountain forest was recorded to already take place during the transition to the Holocene since ca. 14,500 cal yr BP, thus suggesting rising temperature and precipitation at that time (Niemann and Behling, 2009). The trend of warming climatic conditions was also recorded since the beginning of the Holocene (ca. 11,500 cal yr BP) at El Tiro site (Niemann and Behling, 2007), which is located on the wetter eastern slopes (Fig. 1.2, Table 1.1, site: 3). The central and highest part of the PNP at Laguna Rabadilla de Vaca (Fig. 1.2, Table 1.1, site: 4 a) was covered with herb páramo during the beginning of the Holocene, thus indicating relatively cold and wet conditions (Niemann et al., 2009). A shift of mountain forest into higher elevations during early to mid-Holocene times (ca. 9000-3500 cal yr BP) suggested here warmer climatic conditions than at present. This may be related to the Holocene thermal optimum (Niemann et al., 2009). During early to mid-Holocene times, drier (90006400/9700-6900 cal yr BP) and wetter periods (6400-3700/6900-4200 cal yr BP) were reconstructed by considering lake-level fluctuations at the sites of Laguna Cocha Caranga and Rabadilla de Vaca (Niemann and Behling, 2009; Niemann et al., 2009). 
Additionally, drier conditions were recorded at the Cocha Caranga site during late Holocene times (4200-1300 cal yr BP). In the central PNP part, cooler and possibly drier climatic conditions than during the mid-Holocene were indicated for the late Holocene period form ca. 3500 cal yr BP until present, when herb páramo persisted at this high-altitude site (Niemann et al., 2009). Comparably, from ca. 3300 cal yr BP, modern subpáramo vegetation developed at the northern El Tiro site (Niemann and Behling, 2007), while at the site of Cocha Caranga the modern open grassy vegetation with forest patches began to occur around 1300 cal yr BP (Niemann and Behling, 2009). Strong fire intensity, most likely of anthropogenic origin, at this location between ca. 9700-1300 cal yr BP seriously affected the vegetation development (Niemann and Behling, 2009). A high impact of fires on the stability and the vegetation composition of mountain forest ecosystems was also detected in the upper Rio San Francisco valley in the ECSF area (Niemann and Behling, 2010; Fig. 1.2, Table 1.1). Fires in the study area were rare in the late glacial period, but became frequent during Holocene times (Niemann, 2007). After the earliest increase in frequency of fires between ca. 9700 and 7500 cal yr BP (Niemann and Behling, 2007, 2009), a markedly stronger increase in fires was observed at ca. $3500 \mathrm{cal}$ yr BP at El Tiro site (Niemann and Behling, 2007), which coincides with estimations of the first human settlements in the Loja region at ca. 4000 cal yr BP (Guffroy, 2004). Decreased fires during more recent times since ca. 600 cal yr BP at El Tiro, and somewhat earlier (since 1300 or 970 cal yr BP) at other sites, may be a result of reduced human activities during civil conflicts in pre-Inca times (Matthias, 2008; Niemann and Behling, $2009,2010)$. Human impact in the study region was also observed by the presence of Zea mays pollen, resulting from early cultivations (Matthias, 2008; Niemann and Behling, 2010). During the last ca. 50 years, a decrease in arboreal pollen in records of the ECSF area (Fig. 1.2, Table 1.1) reflects forest destruction and nearby human settlements (Niemann and Behling, 2010).

The late glacial and Holocene palaeoecological conditions and changes pertaining to the northern tropical Andes region (Colombia, Ecuador, Peru) and the PNP area, which were briefly summarized above, are discussed in detail and compared to new findings in the chapters $2-4$ of this dissertation.

\subsection{General objectives and outline of chapters}

The main objective of the present study is to increase our knowledge of late Quaternary palaeoenvironmental conditions in the southeastern Ecuadorian Andes with a special focus on the PNP region in the Andean depression region (Fig. 1.1 and 1.2). In this context, this study pursues the following three main research topics:

1. Investigation of past vegetation, climate and fire dynamics at key sites in the PNP area.

This task aims at complementing previous investigations in the study region at locations which have not yet been adequately investigated. New data will contribute to establishing a basis for more in depth comparisons between study sites. Reconstruction of past vegetation changes and identification of environmental conditions, e.g. 
climate changes and human impact regimes, and their influence on local and regional ecosystem dynamics are of primary interest here.

2. Reconstruction and visualization of vegetation dynamics in the PNP area since the late Pleistocene on a regional scale.

To improve our understanding of local and regional environmental changes through time and space, the study's results are integrated into a regional vegetation reconstruction for the PNP area. This approach intends to reveal possible regional analogies and local differences of palaeoecological changes in the PNP area, the Andean depression region and the northern tropical Andes. Visualization of the regional reconstruction contributes to a more comprehensive interpretation of fossil pollen data.

3. Investigation of the relationship between modern pollen rain data and present vegetation/plant diversity patterns.

For appropriate interpretations of fossil pollen records, it is necessary to understand the relationship between present vegetation and modern pollen data. Different statistical analyses are applied in this study to investigate how present vegetation structures and diversity patterns are represented in modern pollen data in the investigated area. The results provide important background information for the investigation of past vegetation changes in the study region based on palynological data.

Chapters are predominantly prepared and arranged as manuscripts for submission to peer-reviewed journals, three of which have already been published. Although this document aimed for a standard and stylistic adaption, editing (e.g. references) may vary between chapters as to comply with the rules of the respective journals. Specific objectives of the chapters are as follows:

Chapter 2 - Pollen analysis of the records CT and CTB from the Cerro Toledo site (Fig. 1.2, Table 1.1, site: $1 \mathrm{a} / \mathrm{b}$ ) provide the first palynological data for the southern PNP area. The reconstruction of the environmental history of this site is the only study in aside from one previous investigation in the northern PNP area reaching back to the late Pleistocene. This analysis facilitates a comparison of southern and northern palaeoenvironments of the PNP over the last 20,000 years and regionally embeds the results.

Chapter 3 - The pollen record of Laguna Campana, situated on the drier western slope at the PNP's outer limits (Fig. 1.2, Table 1.1, site: 2), describes the last ca. 500 years of local vegetation and climate changes in high-resolution. This chapter also includes detailed insights into human impact and interference on the vegetation near the study site, which thus enhances our understanding of past disturbance regimes.

Chapter 4 - This chapter provides a summary of the extensive information on late Quaternary vegetation history in the study area. For the first time, an environmental reconstruction and visualization is done for a part of the wider PNP area on a regional scale, with focus on UFL and vegetation changes for certain time steps over the past ca. 20,000 years. Previously uncertain extents of vertical UFL shifts in the study region are estimated. 
Chapter 5 - Previous investigations by Niemann (2008) on the relationship between modern pollen rain and vegetation in the ECSF area (Fig. 1.2, Table 1.1, site: $\mathrm{ECSF} / \mathrm{RBSF}$ ) in the northern PNP area are revised in order to enhance vegetation reconstructions based on fossil pollen data interpretation. Own research, to include a new multivariate data analysis, updated pollen and vegetation data and interpretations, contributed to this study. The focus lies here on the detection of pollen key taxa, which are specific for one of the present vegetation types, and on the distribution pattern of modern pollen data to compare these with the current distribution of vegetation types and the UFL position.

Chapter 6 - An initial study provides first insight into how present vegetation diversity is reflected in modern pollen data by palynological richness (pollen and spore diversity) along an altitude and diversity gradient within the study area. Results interpreted from data available at this point and described in chapter 5, are presented and connect to future research approaches aiming at the reconstruction of past biodiversity changes.

\subsection{Study region and pollen record sites - an overview}

This section provides a brief, introductory overview of the study region and pollen record sites with a summary of general features and complementary maps. Detailed information on the local conditions of study sites and the wider study region, to include location, vegetation, land use, climate, geomorphology and geology, are presented in the corresponding chapters.

\section{Location}

This study focuses on the investigation of an eastern range of the southern Ecuadorian Andes, the so-called Cordillera Real, which is situated within the biodiversity hotspot of the tropical Andes, northwestern South America (Fig. 1.1, map a). Here, multidisciplinary projects of the current DFG research unit FOR 816 concentrate on mountain ranges extending from ca. 1800 to $3160 \mathrm{~m}$ a.s.l. in the area of the RBSF $\left(3^{\circ} 58^{\prime} 30^{\prime \prime} \mathrm{S}\right.$ and $\left.79^{\circ} 04^{\prime} 25^{\prime \prime} \mathrm{W}\right)$. The RBSF is part of the northern PNP and includes the scientific research station ECSF (Fig. 1.1, map b, Fig. 1.2), situated close to the road between the cities Loja and Zamora at $1850 \mathrm{~m}$ a.s.l. (Fig. 1.2). Due to difficult access to the terrain and the paucity of suitable pollen record sites (e.g. relative small lakes or bogs), palynological studies are spread out in the PNP and nearby surroundings. Various pollen records were obtained during annual field work, and analyses of 15 of these records (Fig. 1.2, Table 1.1) have been completed thus far, with three records palynologically analyzed in this dissertation (chapter 2 and 3; Table 1.1, site: $1 \mathrm{a} / \mathrm{b}, 2$ ). Fossil pollen records are distributed over the western and eastern slopes of the Cordillera Real at the higher altitudes between 1990 and $3312 \mathrm{~m}$ a.s.l., and a modern pollen rain study was carried out in the ECSF/RBSF area (Fig. 1.2, Table 1.1).

The three pollen records analyzed in this study are located at two different sites. 
First, the Cerro Toledo site $\left(04^{\circ} 22^{\prime} 47.7^{\prime \prime} \mathrm{S}, 79^{\circ} 06^{\prime} 69.2^{\prime \prime} \mathrm{W}\right)$ is the southernmost studied location in the PNP area. Two pollen records (CT and CTB) were taken at this site near the crest regions at ca. 3150 and $3110 \mathrm{~m}$ a.s.l., respectively. The second site of Laguna Campana $\left(04^{\circ} 01^{\prime} 28^{\prime \prime} \mathrm{S}, 79^{\circ} 10^{\prime} 40^{\prime \prime} \mathrm{W}\right)$ is located near the northwestern limit of the PNP on the western slope of the Cordillera Real at ca. $2488 \mathrm{~m}$ a.s.l. (Fig. 1.2 . Table 1.1, site: $1 \mathrm{a} / \mathrm{b}, 2)$.

Other available studies on fossil pollen records and on data of a modern pollen rain transect in the study region were used for further analyses and research questions addressed in chapter 4-6 (Table 1.1). These previous investigations are of major interest for this study, and thus their locations are described as follows (Fig. 1.2, Table 1.1. site: 3, 4 a, 5 a). As mentioned above, the modern pollen rain study concentrated on an altitudinal range in the ECSF area $\left(03^{\circ} 58^{\prime} 03^{\prime \prime} \mathrm{S}, 79^{\circ} 04^{\prime} 25^{\prime \prime} \mathrm{W}\right)$ between 1800 and $3185 \mathrm{~m}$ a.s.l., while data of one transect between 1920 and $3185 \mathrm{~m}$ a.s.l. were used in this work. Locations of three other fossil pollen records, which were used as basis for the regional environmental reconstruction, are located in the northern and central PNP. Northernmost of these is the El Tiro site $\left(03^{\circ} 59^{\prime} 23.2^{\prime \prime} \mathrm{S}\right.$, $\left.79^{\circ} 08^{\prime} 42.7^{\prime \prime} \mathrm{W}\right)$ at ca. $2811 \mathrm{~m}$ a.s.l. near the crest region of the Cordillera Real. Laguna Cocha Caranga $\left(04^{\circ} 02^{\prime} 37.5^{\prime \prime} \mathrm{S}, 79^{\circ} 09^{\prime} 45.2^{\prime \prime} \mathrm{W}\right)$ is found little further south at ca. $2710 \mathrm{~m}$ a.s.l. on the western flank of the Cordillera Real and close to Laguna Campana. The Laguna Rabadilla de Vaca $\left(04^{\circ} 15^{\prime} 19.7^{\prime \prime} \mathrm{S}, 79^{\circ} 06^{\prime} 43.7^{\prime \prime} \mathrm{W}\right)$ record site in the central PNP part is located at ca. $3312 \mathrm{~m}$ a.s.l. on the western slopes.

\section{Geomorphological structure}

Compared to the high altitudes of the northern and central Ecuadorian Andes, which reach elevations up to $>6000 \mathrm{~m}$ a.s.l., crests of the southeastern Andes do not exceed $4000 \mathrm{~m}$ a.s.l., and thus are relatively low. These mountains form part of the so-called Girón-Cuenca and Huancabamba Andean depression region (Richter and MoreiraMuñoz, 2005) in the eastern Andean range of southern Ecuador and northern Peru between ca. $3^{\circ}-6^{\circ} \mathrm{S}$ (Fig. 1.3). Volcanoes and glaciers are absent here (Schubert and Clapperton, 1990), but indications of Pleistocene glaciations are found. Heine (2000) estimated lower moraine limits in the eastern Ecuadorian Andes during the LGM at 3750-3500 $\mathrm{m}$ a.s.l., and cirque lakes between 2900 and $3400 \mathrm{~m}$ a.s.l. in the central PNP are remnants of the latest glaciations (Emck, 2007). Studies in the eastern Cordillera near Loja suggested even lowest limits of terminal moraines at 2750-2800 m a.s.l. within the Andean depression region (Rozsypal, 2000). The geomorphologic structure of the study area itself is complex, with mostly steep slopes facing all directions dissected by valleys and basins (Beck et al., 2008b).

\section{Climate}

The climate of Ecuador, including the study area, is dominated by the tropical trade wind regime characterized by strong easterlies throughout the year. The eastern Andean range acts as climatic divide separating the very humid conditions of the Amazon-exposed eastern side of the Cordillera Real from the (semi-) arid climates 


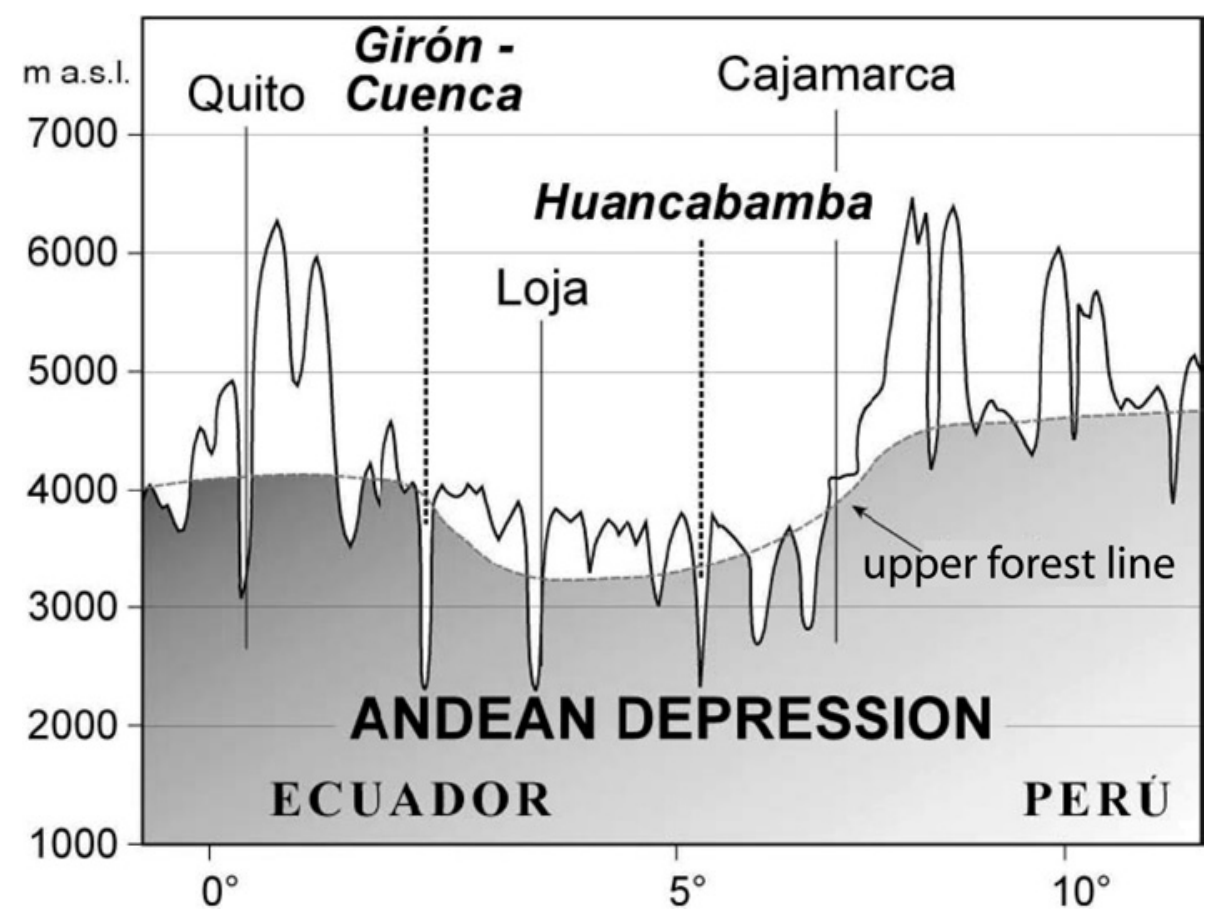

Figure 1.3. Position of the Girón-Cuenca and Huancabamba Andean depression region and the upper forest line depression in this low section of the Andes; source: Richter et al., 2009 (modified).

on the western slopes. Precipitation and humidity continuously rise on the eastern side to the crest regions, where rainfall can reach up to $8000 \mathrm{~mm} \mathrm{a}^{-1}$ (Bendix et al., 2008; Emck, 2007). In the western Inter-Andean basin, a distance of less than $30 \mathrm{~km}$ away, rainfall drops to a minimum of $300 \mathrm{~mm} \mathrm{a}^{-1}$ (Bendix et al., 2008; Emck, 2007). An average of 11-12 humid months is recorded for the eastern escarpment, while the western slopes down to Loja experience only 9-10 humid months (Richter, 2003; Fig. 1.4). Air temperature, which is governed by topography, altitude and ocean temperatures, varies according to the time of day and season (Bendix et al., 2008). Mean annual air temperatures along the altitudinal gradient range from $19-25{ }^{\circ} \mathrm{C}$ (hot land) below $1100 \mathrm{~m}$ a.s.l., and decrease to ca $6{ }^{\circ} \mathrm{C}$ (cold land) at elevations of up to $3800 \mathrm{~m}$ a.s.l., but the thermal regime shows an asymmetric distribution east and west of the Cordillera (Richter, 2003; Beck et al., 2008b; Fig. 1.4). Temperatures below $0{ }^{\circ} \mathrm{C}$ are rare and only occur under anomalous weather conditions at elevations higher than $2800 \mathrm{~m}$ a.s.l. (Emck, 2007).

\section{Vegetation and land use pattern}

The three major landscapes of Ecuador - the drier coastal region, the Amazon rain forest known as "Oriente", and the Andes or "Sierra" - contain a high variety of different vegetation structures (Beck et al., 2008b). Due to the altitudinal gradient and complex climatic conditions, a large number of various vegetation types is already comprised by the Andes alone. Among other descriptions, cited within the following chapters, Homeier et al. (2008) conducted the most appropriate classification of 


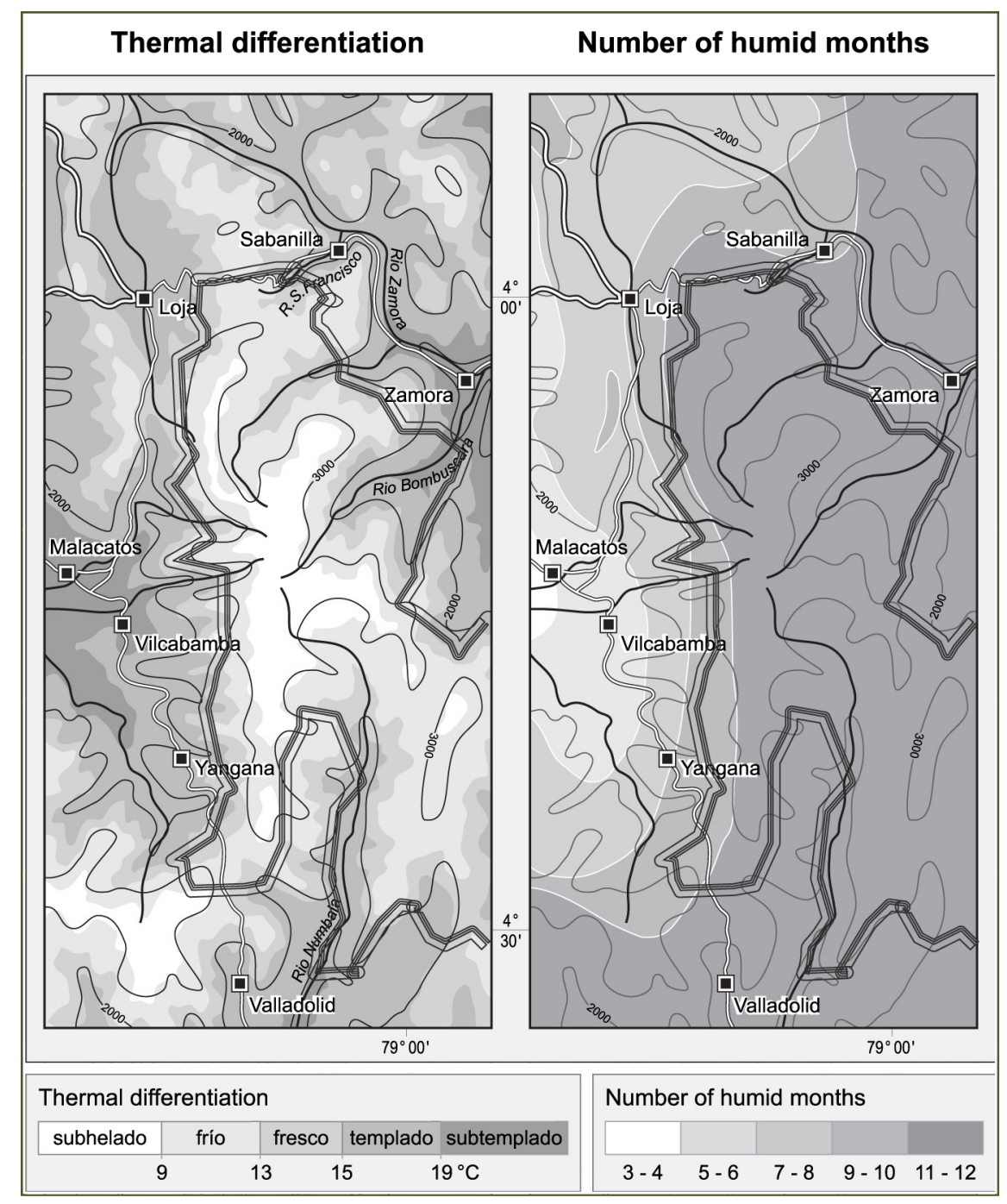

Figure 1.4. Mean annual temperature and number of humid months for the wider Podocarpus National Park area after data of Richter (2003), approximate limits of the PNP were added to the map as gray double line; source: Beck et al., 2008b. 


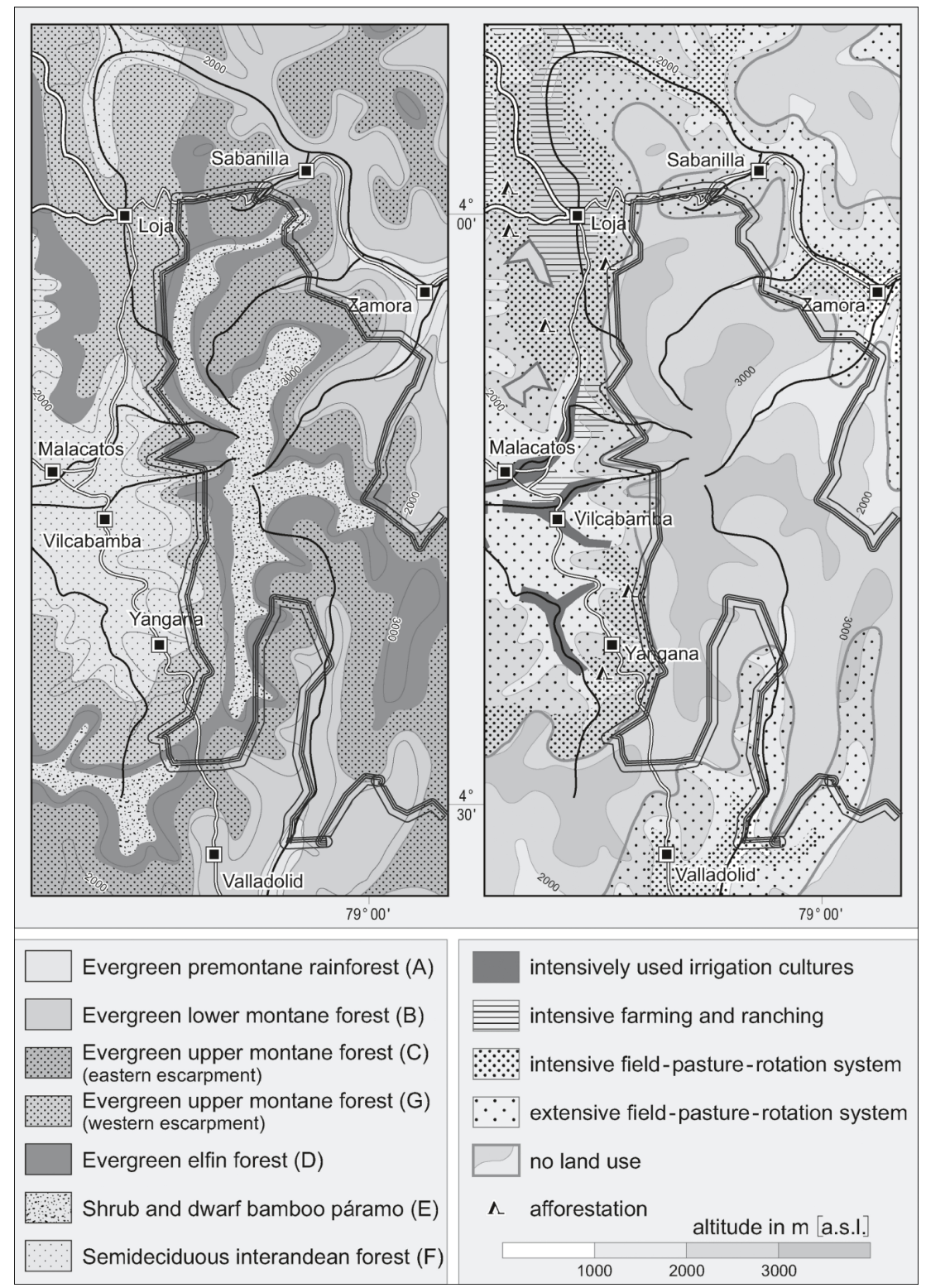

Figure 1.5. Potential natural vegetation and land uses of the Cordillera Real within the wider Podocarpus National Park (PNP) area after Homeier et al. (2008), approximate limits of the PNP were added to the map as gray double line; source: Beck et al., 2008b. 
natural vegetation types within the study region. As shown in Fig. 1.5, they identified seven major vegetation types. According to estimated altitudinal ranges, pre-montane rainforest can be found on the lowest eastern slopes. Lower and upper montane forest exists on increasing terrain heights of the eastern and western escarpments. Maximum tree height of about $40 \mathrm{~m}$ in pre-montane forest gradually decreases with altitude, reaching no more than $6-8 \mathrm{~m}$ in the elfin forest, which forms the UFL above the upper mountain forest. A shrub-dominated subtype of elfin forest is recognized as subpáramo directly above the UFL. Treeless shrub, grass and/or herb dominated páramo covers the crest regions at highest elevations (Homeier et al., 2008).

The UFL, the maximum position where closed forest occurs, is highly variable in the Andean depression and has been less studied than other neotropical forest lines (Richter et al., 2008). In contrast to locations far north and south of the depression region, where the UFL reaches $4000 \mathrm{~m}$ a.s.l. or more, very low UFL positions between ca. $2800 \mathrm{~m}$ and $3200 \mathrm{~m}$ a.s.l. are observed within the PNP area (Richter and MoreiraMuñoz, 2005; Richter et al., 2008; Peters, 2009; Fig. 1.3p. The UFL is formed by a polytypic and species-rich forest, which lacks the otherwise pervasive UFL genus Polylepis and have very complex distribution patterns and structures (Peters, 2009).

Most of the pollen records are taken in the páramo and subpáramo zone or the UFL ecotone, with relatively few records having been obtained in mountain forest so far (Table 1.1, site: $6 \mathrm{~b} / \mathrm{c}$ ). Pollen record sites on the western slopes (Table 1.1. site: 2, 5 a-c, 9) are located in areas influenced by extensive human land use that has caused large-scale forest destruction. Constructions, timber extraction, fires and land conversions have heavily affected the ecosystems of the Cordillera Real and the wider study region (Homeier et al., 2008; Beck et al., 2008b). Disturbances in the PNP area itself are primarily restricted to border zones, a reason why the National Park still widely possesses well-protected natural vegetation (Fig. 1.5).

\subsection{Palynology - some general aspects of methods and applications}

\section{Field work}

Several sediment cores were taken in the study area for palynological analyses during annual field excursions lasting 1-2 weeks. Selected coring sites of relatively small lakes or bogs required different methods and devices. A Livingstone piston corer was used to drill lake sediments, e.g. of Laguna Campana (chapter 3). This corer has aluminum tubes to extract ca. $1 \mathrm{~m}$ long core-sections from carefully measured depths of relative soft sediment. It is generally utilized from a rubber dinghy, which forms a stable platform, to get sediments of the center or deepest part of the lake. If the sediment consistency was very soft, the UWITEC Corer with a special core catcher and a construction that can be adapted for different sediment types was used. These two corers obtained continuous and relatively undisturbed sections of the sediment. To drill out bog sediments, various chamber corers can be used. In this study (chapter 2) the Russian Corer was applied, which extracts sediment samples 
using a $50 \mathrm{~cm}$ half-filled chamber with a $5 \mathrm{~cm}$ diameter. Cores taken in the field are stored under dark and cool $\left(4{ }^{\circ} \mathrm{C}\right)$ conditions, either within the same aluminum or PVC tube (piston/UWITEC corer), or in split PVC tubes (chamber corer) wrapped with plastic film that minimizes drying, oxidation and the influence of light.

\section{Laboratory}

Subsamples of drilled sediments are taken for palynological analysis. Since the sample volume is of major importance for calculations of pollen and spore concentrations and accumulation rates, volumes (generally of 0.25 or $0.5 \mathrm{~cm}^{3}$ ) are sampled by the use of measuring cylinders or other devices. The sample interval depends on the core length and resolution request. The interval chosen for the three cores analyzed in this study were 1, 2, 4 or $8 \mathrm{~cm}$. Samples were filtered using a microstrainer of $150 \mu \mathrm{m}$ (mesh size depending on pollen and spore sizes) and dehydrated with Acetic Acid. The chemical treatment was carried out uniformly for all subsamples, following standard pollen analytical methods after Fægri and Iversen (1989). These included hydrogen chloride (removal of carbonates), hydrofluoric acid (removal of silicate minerals) and acetolyse (removal of cellulose, clearing of exine) treatment. The addition of exotic Lycopodium clavatum spores (one tablet containing $18538 \pm 762$ ) is necessary for calculating concentrations and accumulation rates. To conduct pollen analysis by light microscopy, fixed preparations for each subsample were produced using glycerol gelatin.

\section{Radiocarbon dating}

To compare and correlate stratigraphic records chronologically, it is necessary to date carbonaceous sediments samples. Absolute chronologies (maximum 50,00060,000 years) are often derived from radiocarbon dating, which uses the unstable carbon isotope $14\left({ }^{14} \mathrm{C}\right)$ and its known half-life. Radiocarbon dates with specified error ranges are calibrated to construct age-depth models. However, the construction of an age-depth relationship from these dates is a non-trivial task (Telford et al., 2004), since the many different procedures can give different answers. Some commonly used models include linear interpolation, splines and linear regression models (Bennett, 1994). The variety in calibration methods and age-depth modeling approaches causes the difficulty in obtaining reliable chronologies. The number of dates needed to construct an age-depth model depends e.g. on the required precision and variability of sedimentation rates (Telford et al., 2004). Age-depth models for the three records analyzed in this study were constructed using linear interpolation (chapter 2) and a second order polynomial function (chapter 3). These two methods were considered to be the most appropriate for the present studies.

\section{Pollen and spore identification}

The high plant diversity in tropical regions makes pollen identification a challenging and time consuming task. Therefore, a total pollen count of at minimum 300 pollen 
grains, as common for tropical regions, was carried out in this study (see also chapter 6). Pollen morphological investigations in Colombia by Hooghiemstra (1984) and a reference collection kept at the University of Göttingen containing Neotropical and Ecuadorian pollen and spore types (Behling, 1993) were used as basis for pollen identification. This study helped to amplify the reference collection for Ecuadorian pollen and spores, which now contains about 390 reference plates. Additionally, approximately 200 new preparations are in process and will soon be added to the collection. Following the model of the Neotropical database of the Florida Institute of Technology (Bush and Weng, 2007), a FileMaker database titled "Ecuadorian pollen key" was created and now contains about 410 records of pollen and spores of the study region (fossil and recent material). This database is kept at the University of Göttingen.

Between the three records (Cerro Toledo - CT/CTB, Laguna Campana - LC) and 142 subsamples analyzed (Table 1.2), a total of 237 pollen types were distinguished (see Appendix A), of which 71 types reach family level, 106 genus level and 16 species level. The other pollen types are either unknown types or of higher taxonomic level (e.g. monocots). A total of 78 types of pteridophyta spores were identified (see Appendix A), of which 7 reach family level, 21 genus level and 13 species level. 36 spore types remained unknown. Additionally, algae and few spores of mosses, quilworts and hornworts were identified. The number of pollen and spores recorded for each core vary between 131-155 and 41-49, respectively (Table 1.2).

Table 1.2. Identified palynomorphs (pollen and spores) and other microfossils of three pollen records (chapter 2 and 3 ).

\begin{tabular}{llllll}
\hline Pollen record & Pollen types & $\begin{array}{l}\text { Spore types } \\
\text { (pteridophyta) }\end{array}$ & $\begin{array}{l}\text { Other } \\
\text { microfossils }{ }^{1}\end{array}$ & $\begin{array}{l}\text { No. of } \\
\text { subsamples }\end{array}$ & $\begin{array}{l}\text { Record } \\
\text { age (yr BP) }\end{array}$ \\
\hline Cerro Toledo - CT & 131 & 49 & 2 & 52 & ca. 20,000 \\
Cerro Toledo - CTB & 132 & 41 & 3 & 38 & ca. 10,000 \\
Laguna Campana - LC & 155 & 45 & 5 & 52 & ca. 500 \\
\hline
\end{tabular}

${ }^{1}$ refers to algae as well as spores of mosses and quil-/hornworts

\section{Data presentation}

Palynological results are commonly presented in diagrams, in which sample depths and ages are displayed on the vertical axis, while percentages or other indication of pollen and spore amounts (count data, concentrations, accumulation rates) are shown on the horizontal axis. The calculation of percentages is generally based on the pollen sum (minimum 300 grains) of all pollen originating from terrestrial plants. However, depending on the pollen composition of a record and any possible overrepresentation, the inclusion or exclusion of certain pollen types may vary.

In this study percentage diagrams are displayed, including some with curves of concentrations and accumulation rates. The most significant and important taxa found in the raw data (see Appendix B, here displayed as percentages) were selected for presentation and palaeoecological interpretation in the following chapters. The study attempted to classify as many pollen types as possible into vegetation types as ecological groups (see Appendix A), following the above mentioned vegetation description of Homeier et al. (2008). Though grouping is often difficult, it is worthwhile 
effort because it allows for more meaningful interpretations of summarized pollen assemblages.

\section{Interpretation - explanatory power and limits}

Besides the great insight into past environments provided by palynological and palaeoecological analyses, some methodic limitations should be addressed here as well. Using light microscopy for pollen analysis often causes relatively low taxonomic level of pollen and spores during the identification process. Morphological descriptions are usually limited to the family and genus level and rarely reach species level (see above). Different species or genera of a family can suggest different ecologies or can represent different vegetation types, an important consideration when interpreting palynological data. This makes ecological grouping of pollen types sometimes difficult and causes certain limitations. In regions with high plant diversity, where e.g our study area falls, this may be even more relevant. Varying pollen production, distribution and preservation between plant taxa can cause both overrepresentation and underrepresentation of pollen types in a record, which influences final results if expressed as percentage data. Regarding chronological correlations, various agedepth model approaches and different time resolutions may cause uncertainties when comparing several records (see also chapter 4). This all must be taken into account when interpreting palynological data.

\subsection{References}

Baker, P.A., Seltzer, G.O., Fritz, S.C., Dunbar, R.B., Grove, M.J., Tapia, P. M., Cross, S. L., Rowe, H.D., Broda, J.P., 2001. The History of South American Tropical Precipitation for the Past 25,000 Years. Science 291, 640-643.

Bakker, J., Moscol Olivera, M., Hooghiemstra, H., 2008. Holocene environmental change at the upper forest line in northern Ecuador. The Holocene 18, 1-17.

Barthlott, W., Hostert, A., Kier, G., Küper, W., Kreft, H., Mutke, J., Rafiqpoor, M. D., Sommer, J.H., 2007. Geographic patterns of vascular plant diversity at continental to global scales. Erdkunde 61, 305-315.

Beck, E., Richter, M., 2008. Ecological aspects of a biodiversity hotspot in the Andes of southern Ecuador. Biodiversity and Ecology Series 2, 195-217.

Beck, E., Bendix, J., Kottke, I., Makeschin, F., Mosandl, R. (Eds.), 2008a. Gradients in a tropical mountain ecosystem of Ecuador. Ecological Studies 198, Springer, Berlin, Heidelberg, 525 pp.

Beck, E., Makeschin, F., Haubrich, F., Richter, M., Bendix, J., Valerezo, C., 2008b. The Ecosystem (Reserva Biológica San Francisco). In: Beck, E., Bendix, J., Kottke, I., Makeschin, F., Mosandl, R. (Eds.), Gradients in a tropical mountain ecosystem of Ecuador. Ecological Studies 198. Springer, Berlin, Heidelberg, pp. $1-13$. 
Behling, H., 1993. Untersuchungen zur spätpleistozänen und holozänen Vegetationsund Klimageschichte der tropischen Küstenwälder und der Araukarienwälder in Santa Catarina (Südbrasilien). Dissertationes Botanicae 206, Cramer, Berlin, Stuttgart, $149 \mathrm{pp}$.

Bendix, J., Beck, E., 2009. Spatial aspects of ecosystem research in a biodiversity hot spot of southern Ecuador - an introduction. Erdkunde 63, 305-308.

Bendix, J., Rollenbeck, R., Richter, M., Fabian, P., Emck, P., 2008. Climate. In: Beck, E., Bendix, J., Kottke, I., Makeschin, F., Mosandl, R. (Eds.), Gradients in a Tropical Mountain Ecosystem of Ecuador. Ecological Studies vol. 198, Springer, Berlin, Heidelberg, pp. 63-73.

Bennett, K.D., 1994. Confidence intervals for age estimates and deposition times in late Quaternary sediment sequences. The Holocene 4, 337-348.

Berrio, J.C., Hooghiemstra, H., Marchant, R., Rangel, O., 2002. Late-glacial and Holocene history of the dry forest area in the south Colombian Cauca Valley. Journal of Quaternary Science 17, 667-682.

Broecker, W., 1997. Future directions of paleoecological research. Quaternary Science Review 16, 821-825.

Brunschön, C., Behling, H., 2009. Late Quaternary vegetation, fire and climate history reconstructed from two cores at Cerro Toledo, Podocarpus National Park, southeastern Ecuadorian Andes. Quaternary Research 72, 388-399.

Brunschön, C., Haberzettl, T., Behling, H., 2010. High-resolution studies on vegetation succession, hydrological variations, anthropogenic impact and genesis of a subrecent lake in southern Ecuador. Vegetation History and Archaeobotany 19, 191-206.

Bush, M.B., Colinvaux, P.A., 1988. A 7000-year pollen record from the Amazon lowlands, Ecuador. Vegetatio 76, 141-154.

Bush, M.B., Weng, C., 2007. Introducing a new (freeware) tool for palynology. Journal of Biogeography 34, 377-380.

Bush, M.B., Colinvaux, P.A., Wiemann, M.C., Piperno, D.R., Liu, K.-B., 1990. Late Pleistocene Temperature Depression and Vegetation Change in Ecuadorian Amazonia. Quaternary Research 34, 330-345.

Bush, M.B., Hansen, B.C.S., Rodbell, D.T., Seltzer, G.O., Young, K.R., León, B., Abbott, M.B., Silman, M.R., Gosling, W.D., 2005. A 17000-year history of Andean climate and vegetation change from Laguna de Chochos, Peru. Journal of Quaternary Science 20, 703-714. 
Bush, M.B., Hanselman, J.A., Hooghiemstra, H., 2007. Andean montane forests and climate change. In: Bush, M.B., Flenley, J.R. (Eds.), Tropical rainforest responses to climatic change. Springer, Praxis, pp. 33-54.

Chepstow-Lusty, A., Frogley M.R., Bauer, B.S., Bush, M.B., 2003. A late Holocene record of arid events from the Cuzco region, Peru. Journal of Quaternary Science 18, 491-502.

Churchill, S.P., Balslev, H., Forero, E., Luteyn, J.L. (Eds.), 1995. Biodiversity and conservation of neotropical montane forests. The New York Botanical Garden, Bronx, New York.

Colinvaux, P.A., Frost, M., Frost, I., Liu, K.-B., Steinitz-Kannan, M., 1988a. Three pollen diagrams of forest disturbance in the western Amazon basin. Review of Palaeobotany and Palynology 55, 73-81.

Colinvaux, P.A., Olson, K., Liu, K.-B., 1988b. Late-Glacial and Holocene pollen diagrams from two endorheic lakes of the inter-Andean Plateau of Ecuador. Review of Palaeobotany and Palynology 55, 83-99.

Colinvaux, P.A., Bush, M.B., Steinitz-Kannan, M., Miller, M.C., 1997. Glacial and postglacial pollen records from the Ecuadorian Andes and Amazon. Quaternary Research 48, 69-78.

Di Pasquale, G., Marziano, M., Impagliazzo, S., Lubritto, C., De Natale, A., Bader, M.Y., 2008. The Holocene treeline in the northern Andes (Ecuador): First evidence from soil charcoal. Palaeogeography, Palaeoclimatology, Palaeoecology $259,17-34$.

Emck, P., 2007. A Climatology of South Ecuador - With Special Focus on the Major Andean Ridge as Atlantic-Pacific climate Divide. Dissertation, Universität Erlangen-Nürnberg, Germany, 275 pp.

Fægri, K., Iversen, J., 1989. Textbook of pollen analysis, 4th edn. Wiley, Chichester.

FAO, 2005. Imperiled riches - Threatened rainforests; percent tropical forest loss, 1990-2005. http://rainforests.mongabay.com/deforestation_percent_change.html [16.03.2010]

Guffroy, J., 2004. Catamayo precolombino. Investigaciones arqueológicas en la provincia de Loja (Ecuador). IRD editions, Paris.

Hansen, B.C.S., Rodbell, D.T., 1995. A late-glacial/Holocene pollen record from the eastern Andes of Northern Peru. Quaternary Research 44, 216-227.

Hansen, B.C.S., Seltzer, G.O., Wright, H.E., 1994. Late Quaternary vegetation change in the central Peruvian Andes. Palaeogeography, Palaeoclimatology, Palaeoecology 109, 263-285. 
Hansen, B.C.S., Rodbell, D.T., Seltzer, G.O., León, B., Young, K.R., Abbott, M., 2003. Late-glacial and Holocene vegetation history from two sides in the western Cordillera of southwestern Ecuador. Palaeogeography, Palaeoclimatology, Palaeoecology 194, 79-108.

Heine, K., 2000. Tropical South America during the Last Glacial Maximum: evidence from glacial, periglacial and fluvial records. Quaternary International 72, 7-21.

Homeier, J., Werner, F.A., Gradstein, S.R., Breckle, S.-W., Richter, M., 2008. Potential vegetation and floristic composition of Andean forests in South Ecuador, with a focus on the RBSF. In: Beck, E., Bendix, J., Kottke, I., Makeschin, F., Mosandl, R. (Eds.), Gradients in a Tropical Mountain Ecosystem of Ecuador. Ecological Studies vol. 198, Springer, Berlin, Heidelberg, pp. 87-100.

Hooghiemstra H., 1984. Vegetation and climatic history of the High Plain of Bogota, Colombia: a continuous record of the last 3,5 million years. Dissertationes Botanicae 79, Cramer, Vaduz, 368 pp.

Hooghiemstra, H., van der Hammen, T., 1993. Late Quaternary vegetation history and Laguna Pedro Palo (subandean forest belt, Colombia). Review of Palaeobotany and Palynology 17, 235-262.

Liu, K.-B., Colinvaux, P.A., 1985. Forest changes in the Amazon Basin during the last glacial maximum. Nature 318, 556-557.

Matthias, I., 2008. Rekonstruktion der Umwelt- und Siedlungsgeschichte von Loja durch Multiproxy-Analysen an limnischen Sedimenten der Laguna Daniel Alvarez in Südecuador. Diplomarbeit, Universität Göttingen, Germany (unpublished).

Niemann, H., 2008. Late Quaternary vegetation, climate and fire dynamics in the Podocarpus National Park region, southeastern Ecuadorian Andes. Dissertation, University of Göttingen, Germany, 178 pp.

Niemann H., Behling H., 2007. Late Quaternary vegetation, climate and fire dynamics inferred from the El Tiro record in the southeastern Ecuadorian Andes. Journal of Quaternary Science 23, 203-212.

Niemann H., Behling, H., 2009. Late Pleistocene and Holocene environmental change inferred from the Cocha Caranga sediment and soil records in the southeastern Ecuadorian Andes. Palaeogeography, Palaeoclimatology, Palaeoecology 276, $1-14$.

Niemann, H., Behling, H., 2010. Late Holocene environmental change and human impact inferred from three soil monoliths and the Laguna Zurita multi-proxi record in the southeastern Ecuadorian Andes. Vegetation History and Archaeobotany $19,1-15$. 
Niemann, H., Haberzettl, T., Behling, H., 2009. Holocene climate variability and vegetation dynamics inferred from the (11700 cal. yr BP) Laguna Rabadilla de Vaca sediment record, southeastern Ecuadorian Andes. The Holocene 19, 307-316.

Niemann, H., Brunschön, C., Behling, H., 2010. Vegetation/modern pollen rain relationship along an altitudinal transect between 1920 and $3185 \mathrm{~m}$ a.s.l. in the Podocarpus National Park region, southeastern Ecuadorian Andes. Review of Palaeobotany and Palynology 159, 69-80.

Paduano, G.M., Bush, M.B., Baker, P.A., Fritz, S.C., Seltzer, G.O., 2003. A vegetation and fire history of Lake Titicaca since the Last Glacial Maximum. Palaeogeography, Palaeoclimatology, Palaeoecology 194, 259-279.

Peters, T., 2009. Struktur und ökologische Merkmale der oberen Waldgrenze in der Andinen Depression. Dissertation, Universität Erlangen-Nürnberg, Germany, $257 \mathrm{pp}$.

Richter, M., 2003. Using epiphytes and soil temperature for eco-climatic interpretations in south Ecuador. Erdkunde 57, 161-181.

Richter, M., 2008. Tropical mountain forests - distribution and general features. Biodiversity and Ecology Series 2, 7-24.

Richter, M., Moreira-Muñoz, A., 2005. Climatic heterogeneity and plant diversity in southern Ecuador experienced by phytoindication. Review of Peruvian Biology $12,217-238$.

Richter, M., Diertl, K.-H., Peters, T., Bussmann, R.W., 2008. Vegetation Structures and Ecological Features of the Upper Timberline Ecotone. In: Beck, E., Bendix, J., Kottke, I., Makeschin, F., Mosandl, R. (Eds.), Gradients in a tropical mountain ecosystem of Ecuador. Ecological Studies vol. 198, Springer, Berlin, Heidelberg, pp. 275-280.

Richter, M., Diertl. K.-H., Emck, P., Peters, T., Beck, E., 2009. Reasons for an outstanding plant diversity in the Tropical Andes of Southern Ecuador. Landscape Online 12, 1-35.

Rodríguez, F., Behling, H., 2010. Late Holocene vegetation, fire, climate and upper forest line dynamics in the Podocarpus National Park, south-eastern Ecuador. Vegetation History and Archaeobotany.

Rozsypal, A.A., 2000. Die pleistozäne Glazialmorphologie in Ecuador und Nordperu unter besonderer Betrachtung der Cordillera Oriental bei Loja. Diplomarbeit, Institut für Geographie, Universität Erlangen-Nürnberg (unpublished).

Schubert, C., Clapperton, C.M., 1990. Quaternary glaciations in the Northern Andes (Venezuela, Colombia and Ecuador). Quaternary Science Reviews 9, 123-135. 
Silverman, H., Isbell, W.H. (Eds.), 2008. Handbook of South American Archaeology. Springer, New York, 1199 pp.

Telford, R.J., Heegaard, E., Birks, H.J.B., 2004. All age-depth models are wrong: but how badly? Quaternary Science Reviews 23, 1-5.

van der Hammen, T., Hooghiemstra, H., 2003. Interglacial-glacial Fuquene-3 pollen record from Colombia: an Eemian to Holocene climate record. Global and Planetary Change 36, 181-199.

Vélez M.I., Hooghiemstra, H., Metcalfe, S., Wille, M., Berrío, J.C., 2006. Late Glacial and Holocene environmental and climatic changes from a limnological transect through Colombia, northern South America. Palaeogeography, Palaeoclimatology, Palaeoecology 234, 81-96.

Weng, C., Bush, M.B., Athens, J.S., 2002. Holocene climate change and hydrarch succession in lowland Amazonian Ecuador. Review of Palaeobotany and Palynology 120, 73-90.

Wille, M., Hooghiemstra, H., Behling, H., van der Borg, K., Negret, A.J., 2001. Environmental change in the Colombian subandean forest belt from 8 pollen records: the last 50 kyr. Vegetation History and Archaebotany 10, 61-77.

Wille, M., Hooghiemstra, H., Hofstede, R., Fehse, J., Sevink, J., 2002. Upper forest line reconstruction in a deforested area in northern Ecuador based on pollen and vegetation analysis. Journal of Tropical Ecology 18, 409-440. 



\section{Chapter 2 .}

\section{Late Quaternary vegetation, fire and climate history reconstructed from two cores at Cerro Toledo, Podocarpus National Park, southeastern Ecuadorian Andes}

Brunschön, C. and Behling, H.

Quaternary Research 72 (2009) 388-399

\subsection{Abstract}

The last ca. 20,000 yr of palaeoenvironmental conditions in Podocarpus National Park in the southeastern Ecuadorian Andes have been reconstructed from two pollen records from Cerro Toledo $\left(04^{\circ} 22^{\prime} 28.6^{\prime \prime} \mathrm{S}, 79^{\circ} 06^{\prime} 41.5^{\prime \prime} \mathrm{W}\right)$ at $3150 \mathrm{~m}$ and $3110 \mathrm{~m}$ elevation. Páramo vegetation with high proportions of Plantago rigida characterised the last glacial maximum (LGM), reflecting cold and wet conditions. The upper forest line was at markedly lower elevations than present. After ca. 16,200 cal yr BP, páramo vegetation decreased slightly while mountain rainforest developed, suggesting rising temperatures. The trend of increasing temperatures and mountain rainforest expansion continued until ca. $8500 \mathrm{cal}$ yr BP, while highest temperatures probably occurred from 9300 to 8500 cal yr BP. From ca. 8500 cal yr BP, páramo vegetation re-expanded with dominance of Poaceae, suggesting a change to cooler conditions. During the late Holocene after ca. 1800 cal yr BP, a decrease in páramo indicates a change to warmer conditions. Anthropogenic impact near the study site is indicated for times after 2300 cal yr BP. The regional environmental history indicates that through time the eastern Andean Cordillera in South Ecuador was influenced by eastern Amazonian climates rather than western Pacific climates.

Keywords: Palynology, Vegetation and fire history, Climate dynamics, Late Pleistocene, Holocene, Ecuador, Andes 


\subsection{Introduction}

The tropical eastern Andes and the northern parts of western Amazonia are among the hot spots of global vascular plant diversity due to their high structural and geological diversity (Mutke and Barthlott, 2005). Although the Ecuadorian Andes harbour ecosystems with one of the highest levels of biodiversity on Earth, the country also suffers the highest annual deforestation rates (0.5-2.4\%) of South America, which is causing serious biodiversity loss (Josse, 2001). Especially for the hot spots of species richness, however, the historical environmental development is not well-known. Such knowledge is needed as background information to conserve and manage the ecosystems and their biodiversity.

Only a few palaeoecological studies are available from Ecuadorian Amazonia (Liu and Colinvaux, 1985; Colinvaux, 1987; Bush and Colinvaux, 1988; Liu and Colinvaux, 1988; Colinvaux et al., 1988a; Bush et al., 1990; Weng et al., 2002). Prior investigations from the Andes of Ecuador are restricted to northern locations on the InterAndean Plateau (Colinvaux et al., 1988b) and to southern locations in the western Cordillera (Colinvaux et al., 1997; Hansen et al., 2003). The only available pollen records for the southeastern Andes were provided by recent studies within a large research unit focusing on the Podocarpus National Park (PNP) and its megadiverse mountain ecosystems (Beck et al., 2008a). Several investigations from sites between 2000 and $3300 \mathrm{~m}$ a.s.l. provide reconstructions of the environmental history, mostly of the northern PNP (Niemann and Behling, 2008b; Niemann and Behling, 2009; Niemann et al., 2009).

Here we present the investigation results of two cores from the Cerro Toledo site in the southern part of the PNP area $\left(4^{\circ} \mathrm{S}, 79^{\circ} \mathrm{W}\right)$. Our main objective is the reconstruction of the local environmental history including vegetation, fire and climate dynamics in an attempt to identify mechanisms of past ecosystem change and human impact. Together with previous studies in the northern part of the PNP, an extended environmental history for the PNP area will be reconstructed. A comparison with investigations from nearby sites in the Amazon and western Andes of Ecuador facilitates a regional interpretation of the environmental changes at the southeastern Andes.

\subsection{Study site}

\section{Location}

The study site Cerro Toledo is located in the southern part of the eastern Ecuadorian Andes, the so-called Cordillera Real (Fig. 2.1). It is situated in the Girón-Cuenca and Huancabamba Andean depression between southern Ecuador and northern Peru (lat. $3-7^{\circ} \mathrm{S}$ ), where the highest peaks reach no more than $4000 \mathrm{~m}$ and active volcanoes are absent. Cerro Toledo is situated inside the PNP, some $45 \mathrm{~km}$ southeast of the town of Loja. The two analysed cores Cerro Toledo (CT) and Cerro Toledo B (CTB) are situated close to the exposed crest near the Cerro Toledo pass, which is today a paved road. The core $\mathrm{CT}\left(04^{\circ} 22^{\prime} 28.6^{\prime \prime} \mathrm{S}, 79^{\circ} 06^{\prime} 41.5^{\prime \prime} \mathrm{W}\right)$ was taken at $3150 \mathrm{~m}$ elevation and 


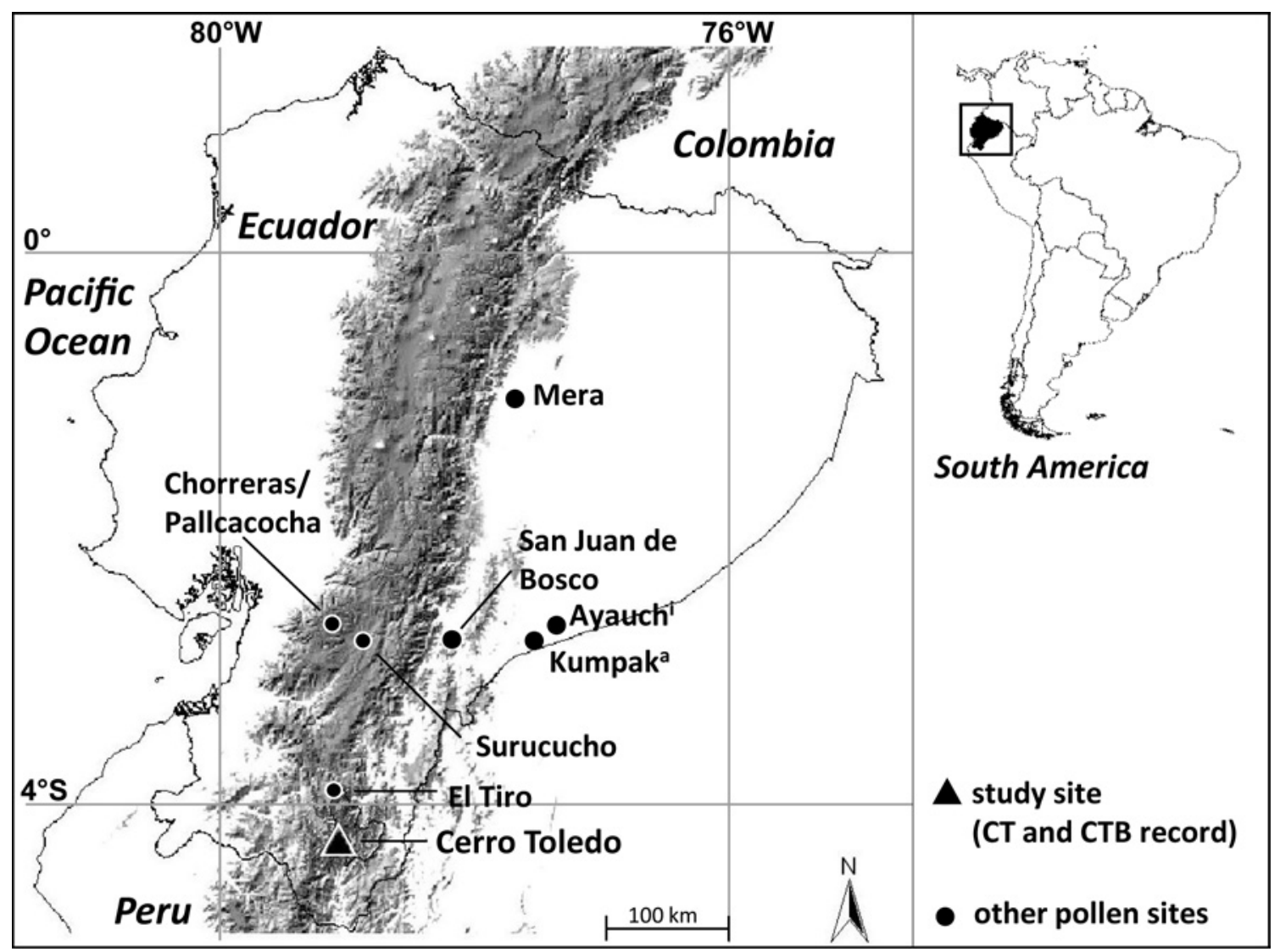

Figure 2.1. Map showing the location of Ecuador, the Andean mountain range as shaded area and study site Cerro Toledo located in the Podocarpus National Park (PNP). In addition relevant pollen record sites in the PNP area (El Tiro) and farther north in the Andes and Amazon basin of Ecuador are displayed.

the core CTB at a distance of ca. $200 \mathrm{~m}$ and ca. $40 \mathrm{~m}$ lower. Both core sites are characterised by small depressions occupied by peat bogs.

\section{Climate}

The climate of Ecuador is dominated by the tropical trade wind regime with strong year-round easterlies (Beck et al., 2008b). Main weather types of the southern Cordillera Real are easterly conditions carrying moist air masses from the Amazon basin (Emck, 2007). Prevailing pressure systems in this region are the subtropical highs over the Atlantic Ocean and southeastern Pacific. The Cordillera Real acts as a climatic divide in Ecuador, separating humid climate on the Amazon-exposed eastern side from arid and semi-arid climate on the west (Emck, 2007). Thus, the study area is located between the humid Amazon basin and the dry Inter-Andean valley (Fig. 2.1). East of the Cordillera, precipitation and humidity rise continuously to the crests accompanied by increasing wind speed. Inside the PNP at $3100 \mathrm{~m}$ a.s.l., rainfall up to $6000 \mathrm{~mm} \mathrm{a}^{-1}$ was measured. In contrast, the Inter-Andean basin receives generally less than $1000 \mathrm{~mm} \mathrm{a}^{-1}$ (Emck, 2007; Bendix et al., 2008a). The main rainy season lasts from April to August but rainfall is high throughout the year. 
Major factors governing air temperature are topography and altitude (Beck et al., 2008b). Temperature varies according to the time of day and season (Bendix et al., 2008a). The coldest period of the year is generally the main rainy season. Mean annual temperature for the páramo is ca. $6.5^{\circ} \mathrm{C}$. Temperatures below $0{ }^{\circ} \mathrm{C}$ are rare and only occur under anomalous weather conditions (Emck, 2007).

The research area is situated in the region where ENSO events cause strong weather anomalies. The coastal plains of southern Ecuador are severely affected by either floods (El Niño) or droughts (La Niña). The effects on the Andean highland are less clear. On the eastern escarpment there is a slight tendency toward reduced rainfall and enhanced temperatures during El Niño. However, ENSO seems not to cause extraordinary weather anomalies due to the fact that the Andes shelter the eastern slopes from Pacific air masses (Bendix et al., 2008b).

\section{Vegetation}

The most appropriate vegetation description by Homeier et al. (2008) classifies 4 different eastern escarpment vegetation types in the PNP, which are relevant for our investigation area: páramo, subpáramo, lower and upper mountain rainforest.

The coring sites are situated in the páramo (including shrub and herb páramo) between ca. $3100-3600 \mathrm{~m}$ a.s.l. above the forest line. Páramo vegetation is characterised by plants with a maximum height of $2 \mathrm{~m}$. Some key species are Puya eryngioides, Chusquea neurophylla, Monnina arbuscula and Valeriana microphylla. A detailed description of the herb páramo in the Cerro Toledo area (Lozano et al., 2003) lists Neurolepis nana, Niphogeton dissecta, Calamgrostis macrophylla, Halenia weddelliana, Valeriana convallarioides and Huperzia kuesteri.

Subpáramo vegetation, a subtype of elfin forest forming the forest line, occurs between ca. 2700-3100 m a.s.l. covering most of the Cerro Toledo region. Canopy heights are 6-8 m or somewhat lower. Characteristic species are Clethra ovalifolia, Gaultheria reticulata, Gaiadendron punctatum and Hesperomeles ferruginea.

Upper mountain rainforest (UMF) is located between ca. 2100-2700 m a.s.l. and the canopy attains heights up to $25 \mathrm{~m}$. Some of the main key species are Hedyosmum sp., Clethra revoluta, Weinmannia sp., Myrsine coriacea and Podocarpus oleifolius.

The lowest vegetation type is the lower mountain rainforest (LMF) between ca. 1300$2100 \mathrm{~m}$ a.s.l. with canopy heights of $30 \mathrm{~m}$. Characteristic species are Cedrela montana, Morus insignis, Piper sp. and Heliocarpus americanus.

\section{Upper forest line}

The upper forest line (UFL) is defined as the maximum elevation where continuous forest occurs (see also Bakker et al., 2008). In the Andean depression the UFL is highly variable and not as well understood as other neotropical forest lines (Richter et al., 2008). North and south of the depression, the UFL is located at $4000 \mathrm{~m}$ a.s.l. or even higher, while the South Ecuadorian UFL is comparatively low between 2800$3300 \mathrm{~m}$ a.s.l. (Richter and Moreira-Muñoz, 2005; Beck et al., 2008b). The low position of the UFL in South Ecuador is characterised by the absence of Polylepis. 
Frequent strong winds and the extremely high precipitation are considered to be the main factors for the absence of Polylepis, because the genus tends to avoid regions of perhumid conditions (Kessler, 1995; Richter and Moreira-Muñoz, 2005). The higher located UFL is mainly formed by a Polylepis belt sometimes joined by Gynoxis trees, while the lower one represents an ecotone consisting of about 20 tree species (Beck et al., 2008c).

\subsection{Methods}

The cores were taken with a Russian Corer and stored under dark and cold $\left(4{ }^{\circ} \mathrm{C}\right)$ conditions. For AMS radiocarbon dating, 7 subsamples were submitted to the University of Erlangen-Nürnberg and Poznan Radiocarbon Laboratory. The ${ }^{14} \mathrm{C}$ dates were calibrated using CalPal Online and the CalPal 2007 HULU curve (Weninger et al., 2004). For palynological analysis the CT core was sampled at 2-cm intervals, the CTB core at 4-cm intervals and from $160 \mathrm{~cm}$ to the base every $8 \mathrm{~cm}$. All samples were processed using standard pollen analytical methods (Fægri and Iversen, 1989). For calculations of concentration and influx Lycopodium spores were added as marker. A minimum of 300 pollen grains were counted for each sample. The pollen sum includes pollen of trees, shrubs and herbs. Pteridophyta, Isoëtes and moss spores were counted and quantified as percentages relative to the pollen sum. Carbonised particles $(5-150 \mu \mathrm{m})$ were counted on pollen slides and presented as charcoal concentration and influx. Identification of pollen and spores was based on a published pollen reference from Colombia (Hooghiemstra, 1984) and the reference collections (Behling, 1993) kept at the Department of Palynology and Climate Dynamics, University of Gottingen, containing approximately 3000 Neotropical and 300 Ecuadorian pollen and spore types. Identified pollen and spores were classified in ecological groups regarding the vegetation types of Homeier et al. (2008). TILIA, TILIAGRAPH and CONISS (Grimm, 1987) were used for data calculation, illustration and cluster analysis. In addition, non-destructive magnetic susceptibility $(\kappa)$ was measured for the $\mathrm{CT}$ core with a Bartington MS2F point sensor in 1-cm intervals.

\subsection{Results}

\section{Stratigraphy}

Detailed sediment descriptions of both cores are presented in Table 2.1 and 2.2. The CT core consists of a ca. 50-cm-thick silty clayey base followed by a gradual transition (134-107 cm) to highly decomposed peaty material. From 107 to $31.5 \mathrm{~cm}$, the sediment consists of black or brown decomposed peaty material. A thick sand layer between 31.5 and $6 \mathrm{~cm}$ disrupts the core, while the top $6 \mathrm{~cm}$ are characterised by organic material with a high proportion of Sphagnum. The base of the CTB core is formed by moist and decomposed material $(235-100 \mathrm{~cm})$. Upwards the core the sediment gets less decomposed and compact. The top $27 \mathrm{~cm}$ consist of brown and moist peat. 
Table 2.1. Stratigraphic description of the Cerro Toledo CT core.

\begin{tabular}{ll}
\hline Depth $\mathbf{( c m )}$ & Description \\
\hline $0-6$ & Dark-brown/green plant remains with high proportion of Sphagnum \\
$6-14$ & Yellow, clayey mixed erosion material \\
$14-31.5$ & Yellow greyish coarse-grained sand erosion material \\
$31.5-45$ & Dark-brown, highly decomposed peaty material, with plant remains and rootlets \\
$45-82$ & Black-brown, highly decomposed peaty material, with plant remains and rootlets \\
$82-96$ & Dark-brown highly decomposed peaty material, with plant remains and rootlets \\
$96-107$ & Black-brown, highly decomposed peaty material, with plant remains and rootlets \\
$107-134$ & Brown, highly decomposed peaty material, no plant remains, gradually transition zone \\
& from brown to light brown coloured material (conspicuous transition beginning at $125 \mathrm{~cm})$ \\
$134-182$ & Light brown/grey and very compact silty clay \\
\hline
\end{tabular}

Table 2.2. Stratigraphic description of the Cerro Toledo CTB core.

\begin{tabular}{ll}
\hline Depth $\mathbf{( c m )}$ & Description \\
\hline $0-27$ & Brown peaty material with less-decomposed plant remains (rootlets) \\
$27-75$ & Dark-brown/black decomposed peat with plant remains, more compact \\
$75-100$ & Brown compact peat with many plant remains \\
$100-142$ & Dark-brown/black decomposed peat with plant remains, more compact \\
$142-235$ & Black-brown, highly decomposed and compact peat \\
\hline
\end{tabular}

\section{Chronology}

The chronologies of the two cores are based on 7 radiocarbon dates, 5 for the $\mathrm{CT}$ core and 2 for the CTB core (Table 2.3). The ages for the CT core are consistent (Fig. 2.2) and the basal age of $16,778 \pm 137{ }^{14} \mathrm{C}$ yr BP indicates that the core extends back to the last glacial maximum (LGM). The sand layer in this core was probably deposited when the road along the Cerro Toledo pass was constructed 15-20 yr ago (Richter, M., personal communication, 2007). Deposition most likely occurred almost instantaneously. Accordingly, top and bottom of the sand layer were defined with the age of -37 cal yr BP, excluding the layer from the age scale. The age-depth model reveals a sedimentation rate of $0.04-0.25 \mathrm{~mm} \mathrm{yr}^{-1}$ up to the sand layer. The top of the core shows comparatively high accumulation rates of $3.33 \mathrm{~mm} \mathrm{yr}^{-1}$ (Fig. 2.3). The CTB core covers the Holocene, as extrapolated from the lower age at $122 \mathrm{~cm}$ of $4435 \pm 35{ }^{14} \mathrm{C}$ yr BP. Extrapolation of ages to the core base were considered feasible because of analogy with the CT core and uniform stratigraphy suggesting continuous sediment accumulation.

Table 2.3. List of radiocarbon dates of samples from the Cerro Toledo cores CT and CTB.

\begin{tabular}{|c|c|c|c|c|c|c|}
\hline Core & Lab. - no. & Depth (cm) & $\begin{array}{l}{ }^{14} \mathrm{C} \text { age } \\
(\mathrm{yr} \mathrm{BP})\end{array}$ & $\begin{array}{l}\text { Calibrated } \\
\text { age }^{1}\end{array}$ & $\begin{array}{l}\text { 1- } \sigma \text { range } \\
(\text { cal yr } \mathbf{B P})\end{array}$ & $\begin{array}{l}\text { Dated } \\
\text { material }\end{array}$ \\
\hline \multirow[t]{4}{*}{$\mathrm{CT}$} & Poz-24271 & $65-65.5$ & $4280 \pm 35$ & $4854 \pm 13$ & $4841-4867$ & organic material \\
\hline & Erl-11397 & $83-84$ & $8101 \pm 52$ & $9056 \pm 56$ & $9000-9112$ & organic material \\
\hline & Erl-11030 & 108-109 & $12627 \pm 100$ & $14984 \pm 324$ & 14659-15308 & organic material \\
\hline & Erl-8373 & $179.5-180.5$ & $16778 \pm 137$ & $19999 \pm 311$ & $19687-20310$ & organic material \\
\hline \multirow[t]{2}{*}{ CTB } & Poz-24270 & $58-58.5$ & $2245 \pm 30$ & $2257 \pm 64$ & $2192-2321$ & organic material \\
\hline & Poz-24272 & 122 & $4435 \pm 35$ & $5094 \pm 122$ & $4972-5216$ & piece of wood \\
\hline
\end{tabular}




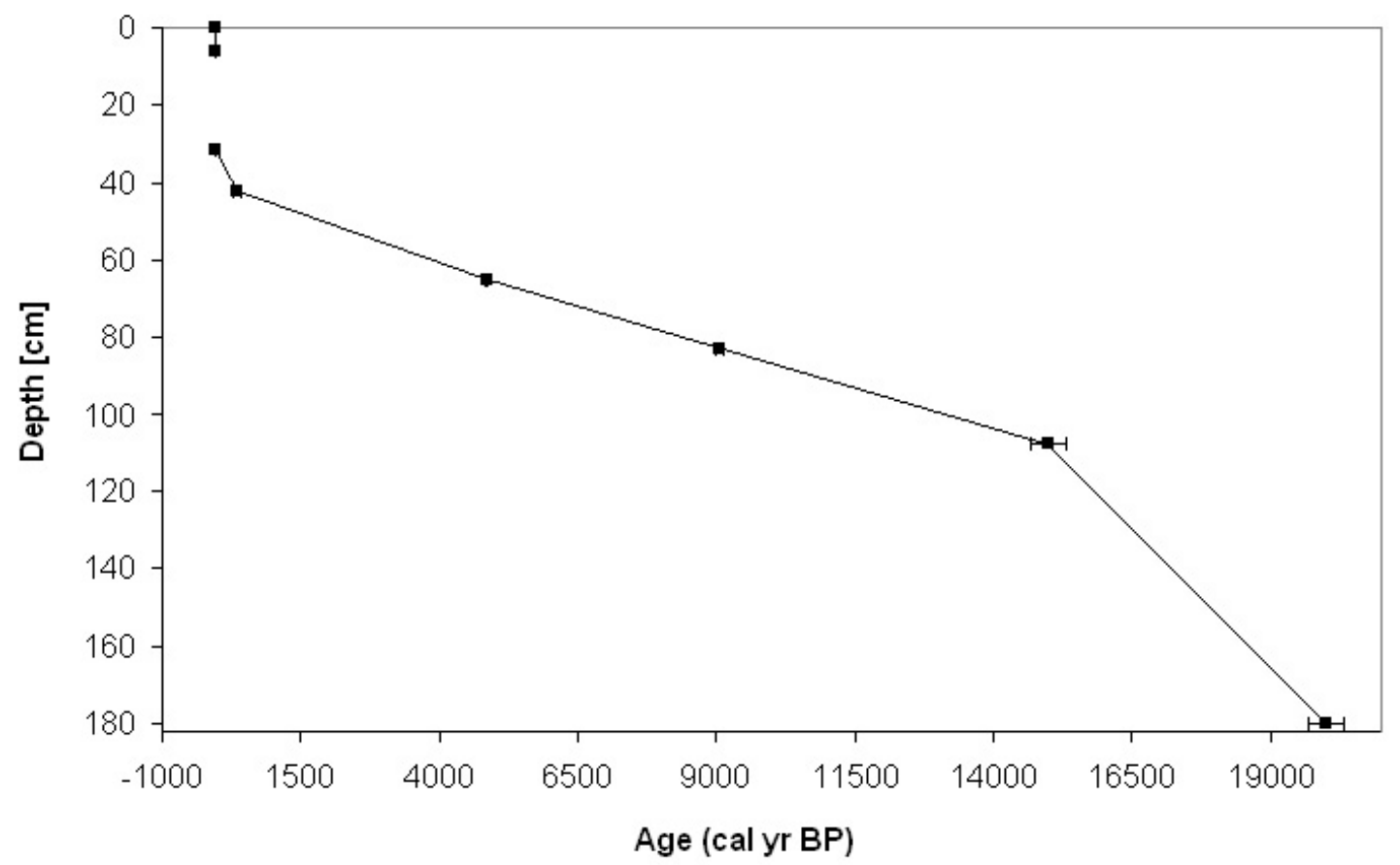

Figure 2.2. Age-depth model for the $\mathrm{CT}$ core based on 5 radiocarbon dates illustrating core ages (x-axis) compared to core depth (y-axis).

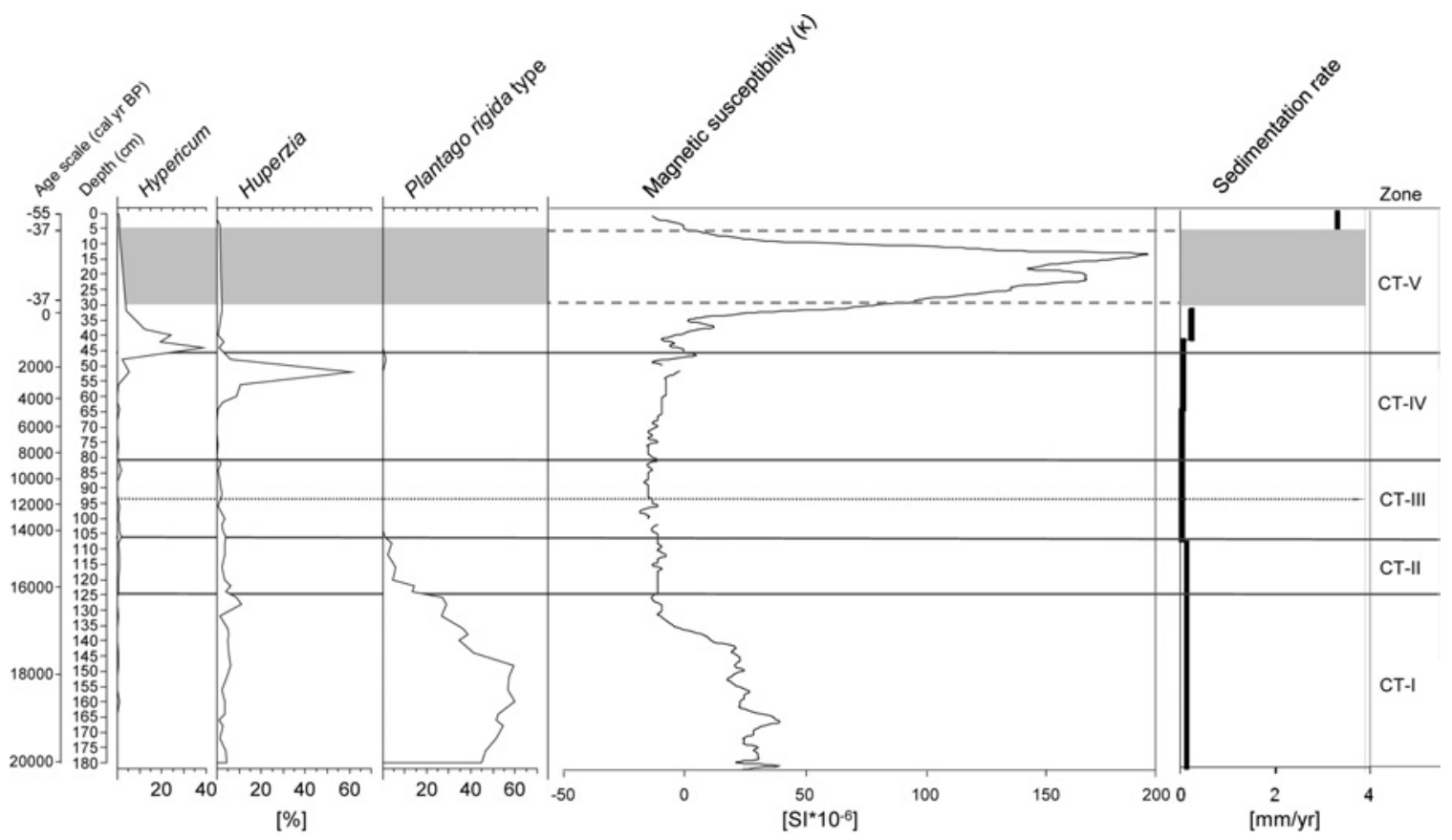

Figure 2.3. Magnetic susceptibility $(\kappa)$ and sedimentation rate of the $\mathrm{CT}$ core compared to abundances of selected pollen types: Hypericum, Huperzia, Plantago rigida type. 


\section{Description of pollen diagrams of the CT core}

A detailed percentage diagram (Fig. 2.4) displays 32 of the most frequent and important taxa out of 131 pollen and 52 spore types encountered. The summary percentage diagram (Fig. 2.5) shows the pollen and spores grouped into the different vegetation types. The dendrogram indicates 5 different zones (CT-I to V, Fig. 2.4).

Pollen concentrations $\left(14,600-1,326,000\right.$ grains $\left.\mathrm{cm}^{-3}\right)$ as well as pollen influx (40019,000 grains $\mathrm{cm}^{-2} \mathrm{yr}^{-1}$ ) do not vary markedly throughout the core. Exceptions are high pollen concentration and influx just above the sand layer at $6 \mathrm{~cm}$ of 42,000 grains $\mathrm{cm}^{-2} \mathrm{yr}^{-1}$. Charcoal concentrations (5000-1,338,000 particles $\mathrm{cm}^{-3}$ ) and charcoal influx (200-25,000 particles $\mathrm{cm}^{-2} \mathrm{yr}^{-1}$ ) are relatively low throughout the lower part of the core. Significantly higher values up to 239,000 particles $\mathrm{cm}^{-2} \mathrm{yr}^{-1}$ are found in the uppermost part close to the sand layer at 32 and $6 \mathrm{~cm}$ (Fig. 2.5).

Zone CT-I (182-125 cm, ca. 20,000-16,200 cal yr BP, 17 samples) is characterised by a high proportion (65-85\%) of páramo taxa, primarily Plantago rigida (30-60\%) and P. australis (1-6\%), Apiaceae (8-20\%), Poaceae (7-15\%), Cyperaceae (2-9\%) and Valeriana (1-3\%). Much less frequent (1-11\%) are taxa of the subpáramo vegetation, mainly represented by pollen of Melastomataceae and Asteraceae (0-2\%). A slight increase in subpáramo taxa to the top of this zone is due to the increase in Melastomataceae pollen to $9 \%$. The group of UMF with values between $5 \%$ and $15 \%$ is mainly represented by Alnus (2-7\%), Hedyosmum (0-4\%), Weinmannia (0-3\%), Myrsine (0-2\%) and Podocarpaceae pollen (1-2\%). The Podocarpaceae group consists most probably of Podocarpus, but Prumnopitys pollen not distinguished so far has to be considered as well. LMF taxa are poorly represented (0-4\%), as percentages of Moraceae/Urticaceae (0-2\%), Acalypha (0-2\%) and Alchornea pollen (0-1\%) are low. Pteridophyta, mostly spores of Huperzia, vary between $7 \%$ and $14 \%$.

Zone CT-II (125-107 cm, ca. 16,200-14,700 cal yr BP, 6 samples) is marked by a strong decrease in páramo taxa at the top of this zone from $65 \%$ to $44 \%$, reflected by decreasing pollen types of Plantago rigida, P. australis, Apiaceae and Cyperaceae to levels of $2 \%$ or even lower. However, Poaceae pollen increases as an important páramo taxa from $11 \%$ to $45 \%$. The subpáramo group reaches high values between $14 \%$ and $16 \%$ mainly due to Melastomataceae pollen (8-13\%). UMF taxa increase within this zone to $24 \%$ mostly due to higher percentages of Hedyosmum (1-5\%), Weinmannia (1-6\%) and Podocarpaceae pollen (1-4\%). LMF taxa increase from $6 \%$ to $12 \%$ with higher proportions of Moraceae/Urticaceae (1-6\%) and Celtis pollen (0-3\%). Isoëtes spores appear with a strong increase to $433 \%$ (relative to the pollen sum) at $108 \mathrm{~cm}$ core depth.

Zone CT-III (107-81 cm, ca. 14,700-8600 cal yr BP, 9 samples) shows a decrease to $39 \%$ in páramo taxa, due to a decrease in Poaceae pollen from $43 \%$ to $23 \%$. Pollen types of Plantago rigida, P. australis and Apiaceae disappears, while Cyperaceae pollen increases to $13 \%$ in the lower part of the zone. The highest value (14\%) of Valeriana pollen is reported at the top of this zone. Subpáramo taxa remain stable between $8 \%$ and $14 \%$ with only one peak of $24 \%$ at $92 \mathrm{~cm}$ depth, mainly represented by maxima of Melastomataceae (12\%) and Asteraceae pollen (10\%). Compared to the previous zone, UMF taxa decrease from $24 \%$ to $10 \%$. This is mainly due to decreas- 
ing values of Alnus, Hedyosmum and Weinmannia pollen to $2 \%$ or $1 \%$. LMF taxa increase markedly and reach the maximum proportion of $32 \%$ most notably by the strong increase of Moraceae/Urticaceae pollen from $4 \%$ to $24 \%$. Pteridophyta spores fluctuate like previously but show generally higher values. Spores of Cyatheaceae (1-5\%) are more frequent, whereas Huperzia spores become less important (1-4\%) in this zone. Spores of Isoëtes first decrease and subsequently disappear.

Zone CT-IV (81-46 cm, ca. 8600-1100 cal yr BP, 10 samples) shows an increase in páramo taxa, primarily represented by high occurrence up to $65 \%$ of Poaceae pollen. Compared to former zones a constant lower frequency of subpáramo taxa (ca. 10\%) is mainly represented by pollen of Melastomataceae and Asteraceae. At the top of this zone, Hypericum pollen appears with 5\%. Compared to decreasing values of the previous zone, the UMF group shows slightly higher and stable proportions between $13 \%$ and $19 \%$, mainly due to higher values up to $11 \%$ of Podocarpaceae pollen. Lower frequencies between $3 \%$ and $12 \%$ of LMF taxa are mainly due to the decrease of Moraceae/Urticaceae pollen to a low value of $1 \%$ at the top of this zone. Sphagnum spores first appear in this zone and increase to values of $18 \%$. Pteridophyta, primarily Huperzia spores, increase up to the highest value of $69 \%$ and decrease subsequently to $18 \%$.

Zone CT-V (46-0 cm, ca. 1100 cal yr BP to recent times, 10 samples) shows first lower values $(25 \%)$ of páramo taxa than in the previous zone, but towards and above the sand layer proportions increase up to 70\%. Páramo composition changes within this zone as Poaceae pollen decreases to $2 \%$ and Cyperaceae pollen increases from $1 \%$ to $18 \%$. Pollen of Moritzia appears for the first time and reaches high proportions between $10 \%$ and $50 \%$ in the upper $4 \mathrm{~cm}$. Concurrently Valeriana pollen re-occurs and reaches high values of $13 \%$. Subpáramo taxa increase at the beginning of this zone, primarily because of the high value (39\%) of Hypericum pollen, and subsequently decrease from 53\% to $9 \%$. UMF and LMF taxa do not exceed $20 \%$ or $14 \%$, respectively. Sphagnum spores decrease compared to the previous zone and fluctuate between $0 \%$ and $17 \%$, with one exception of the highest peak $(87 \%)$ before the sand layer. Pteridophyta spores vary from $3 \%$ to $18 \%$. 


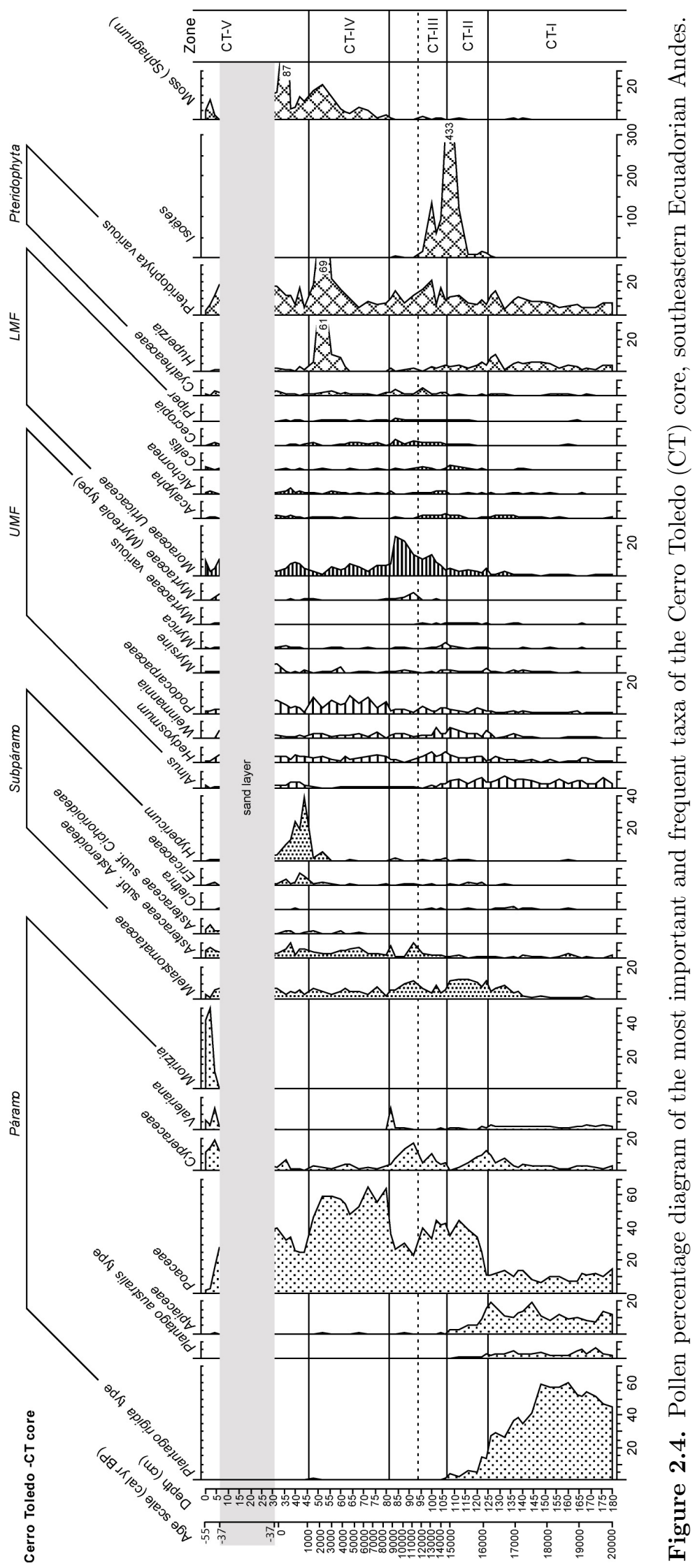




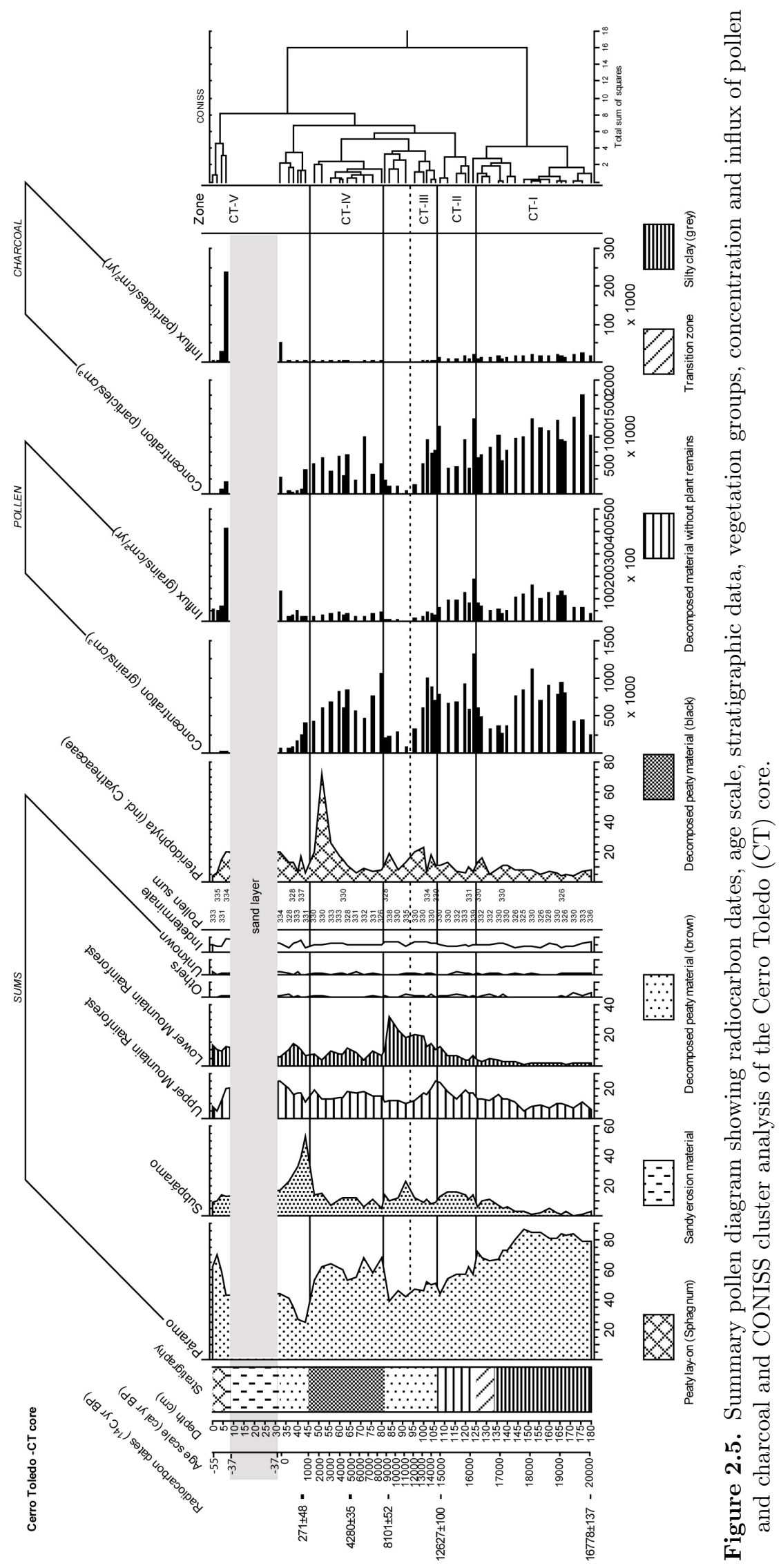




\section{Description of pollen diagrams of the CTB core}

The most abundant 28 taxa from a total of 133 pollen and 42 spore types are shown in a detailed percentage diagram (Fig. 2.6). Identified pollen and spores grouped into different vegetation types are illustrated by a summary percentage diagram (Fig. 2.7). Five zones are distinguished by cluster analysis (CTB-I to V, Fig. 2.6). Pollen concentration (56,000-760,000 grains $\mathrm{cm}^{-3}$ ) and pollen influx (1400-19,000 grains $\mathrm{cm}^{-2} \mathrm{yr}^{-1}$ ) remain relatively stable but increase in the upper part of the core (zone CTB-V). The relatively low values of charcoal concentration $\left(31,000-800,000\right.$ particles $\left.\mathrm{cm}^{-3}\right)$ and charcoal influx (700-20,000 particles $\mathrm{cm}^{-2} \mathrm{yr}^{-1}$ ) increase in zone CTB-V (Fig. 2.7).

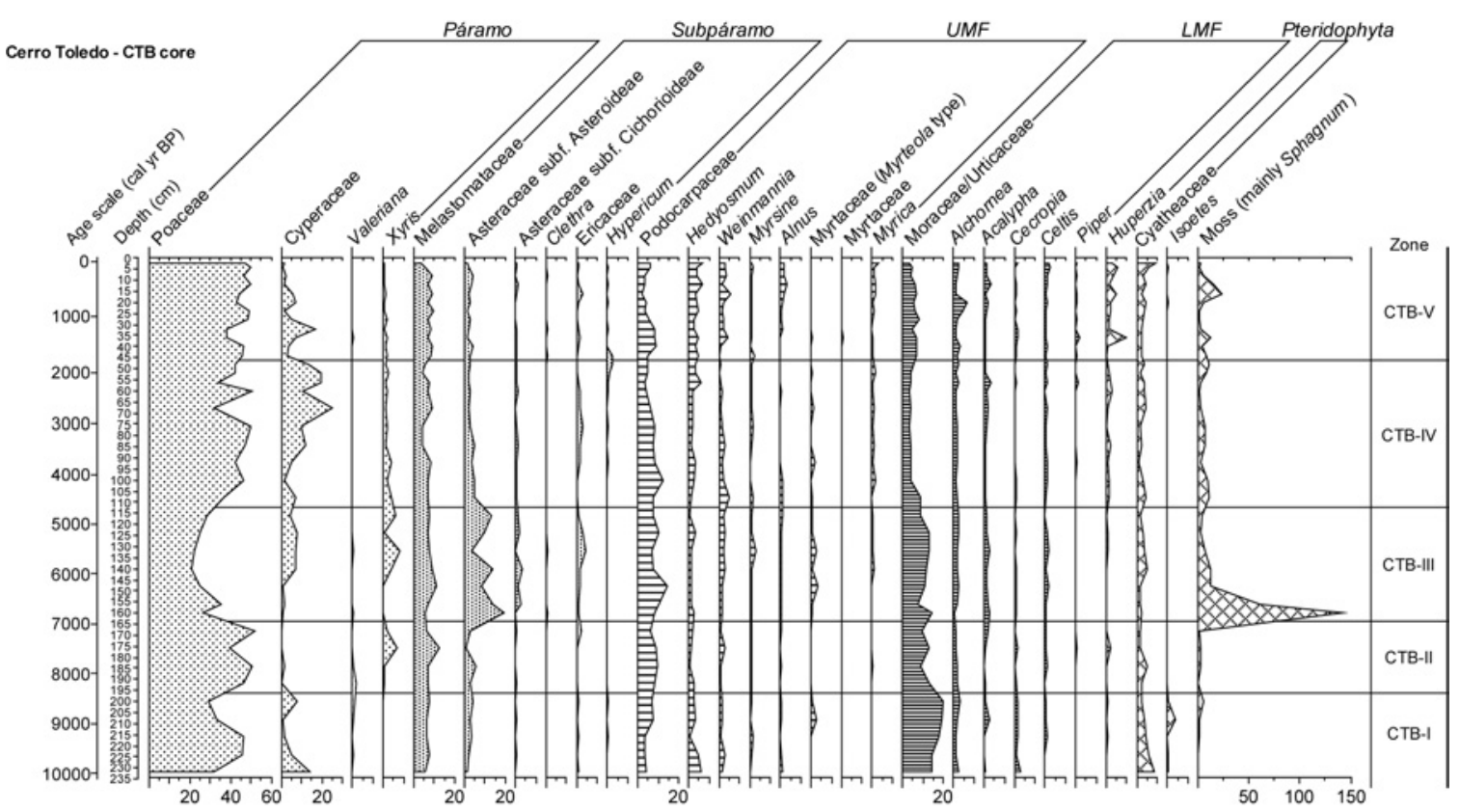

Figure 2.6. Pollen percentage diagram of the most important and frequent taxa of the Cerro Toledo (CTB) core, southeastern Ecuadorian Andes.

Zone CTB-I (235-196 cm, ca. 10,000-8400 cal yr BP, 5 samples) is characterised by high proportions (35-51\%) of páramo taxa consisting mainly of Poaceae pollen between $29 \%$ and $47 \%$ and Cyperaceae pollen up to $14 \%$. Subpáramo taxa are relatively stable with $9 \%$ to $14 \%$, represented by pollen of Melastomataceae (6-8\%) and Asteraceae (1-4\%). UMF taxa vary between $8 \%$ and $17 \%$, primarily due to Podocarpaceae (3-7\%), Hedyosmum (1-6\%) and Weinmannia (1-3\%) pollen. LMF taxa increase slightly to the top of this zone and reach proportions up to $27 \%$ mostly consisting of Moraceae/Urticaceae pollen (14-20\%). Spores of pteridophyta are represented by slightly increasing values from $7 \%$ to $10 \%$, while Cyatheaceae spores show a decreasing trend from 3\% to 9\%. Moss spores, mainly Sphagnum, increase up to $6 \%$ toward the top of the zone. Isoëtes spores are rare with a maximum of $4 \%$.

Zone CTB-II (196-164 cm, ca. 8400-6900 cal yr BP, 4 samples) shows a further increase in páramo up to $55 \%$, dominated by pollen of Poaceae (40-52\%). Cyperaceae pollen decreases markedly compared to the previous zone to values between $0 \%$ and 


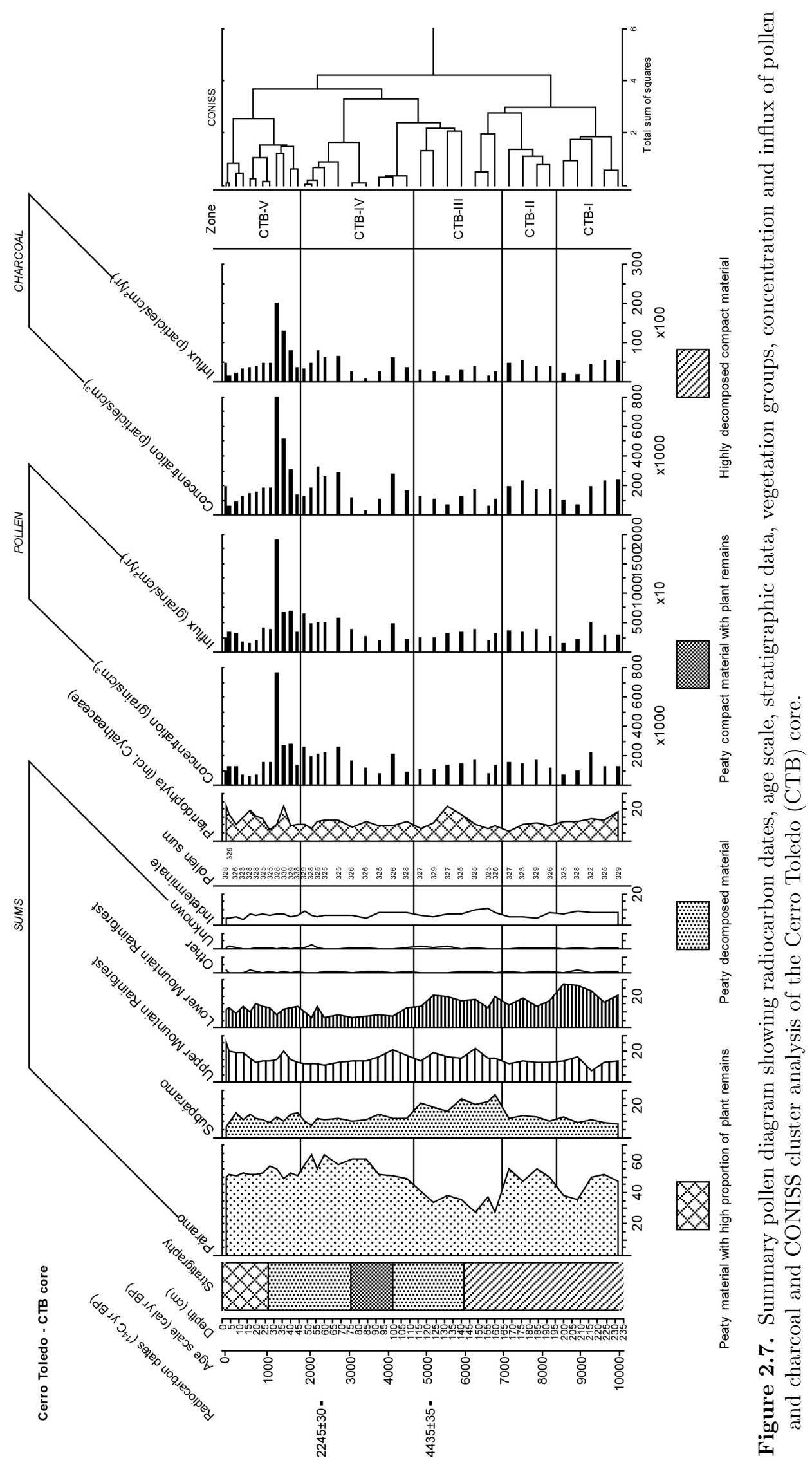


2\%. Xyris pollen (1-7\%) appears mostly in the second part of this zone. Subpáramo taxa show no marked changes. The same is true for UMF taxa, except for Podocarpaceae pollen that reaches higher percentages between $6 \%$ and $10 \%$ in this zone. A decrease in LMF taxa from $27 \%$ to $14 \%$ is indicated by the decrease of Moraceae/Urticaceae pollen from $20 \%$ to $9 \%$. The decreasing trend of pteridophyta spores continues and Cyatheaceae spores (2-5\%) are less important. Moss spores (1-3\%) stay at low percentages and spores of Isoëtes are absent.

Zone CTB-III (164-112 cm, ca. 6900-4700 cal yr BP, 7 samples) shows lower proportions of minimum $28 \%$ of páramo taxa in the first part of the zone, but they recover in the top of the zone reaching values of $41 \%$. This is mainly due to Poaceae pollen varying between $21 \%$ and $36 \%$. Pollen of Cyperaceae and Xyris increases upwards from $140 \mathrm{~cm}$ core depth and reaches 8\%. Subpáramo taxa are represented in this zone by higher percentages between $17 \%$ and $28 \%$, mainly because of higher values of Asteraceae (4-19\%) and Ericaceae (1-4\%) pollen. Also, UMF taxa reach higher frequencies between $14 \%$ and $22 \%$, in particular shown by pollen of Podocarpaceae (7$15 \%$ ) and Myrtaceae (1-3\%). Spores of pteridophyta increase first to $18 \%$ at $132 \mathrm{~cm}$ core depth and decrease afterwards to 7\%. Mosses, namely Sphagnum spores, first increase markedly to the highest value of $142 \%$ and subsequently decrease to low percentages comparable to the previous zones.

Zone CTB-IV (112-46 cm, ca. 4700-1800 cal yr BP, 10 samples) is marked by an increase in páramo taxa to their highest value of $64 \%$, attributed primarily to high proportions of Poaceae pollen (34-50\%) and increasing percentages of Cyperaceae pollen to highest values of $25 \%$. Subpáramo taxa decrease again from $15 \%$ to $8 \%$ but pollen of Melastomataceae remains at same levels. UMF taxa show a slight decrease to $11 \%$ in this zone, primarily due to the decrease of Podocarpaceae pollen to $4 \%$. A more significant decrease occurs for LMF taxa from $13 \%$ to $6 \%$, mainly due to the low values $(3 \%)$ of Moraceae/Urticaceae pollen. Pteridophyta spores vary between $6 \%$ and $10 \%$ and spores of mosses remain at low frequencies $(1-11 \%)$.

Zone CTB-V (46-0 cm, ca. $1800 \mathrm{cal}$ yr BP to recent times, 12 samples) shows a stable proportion of páramo taxa $(48-57 \%)$ at slightly lower levels than in the prior zone. Poaceae pollen (38-50\%) remains stable, while Cyperaceae pollen decreases significantly to $1 \%$. Subpáramo taxa increase slightly and vary from $7 \%$ to $17 \%$, mainly by pollen of Melastomataceae (4-10\%) and Asteraceae (1-4\%). UMF taxa increase markedly to the highest value of $25 \%$ at the top of the core, primarily due to higher pollen frequencies of Hedyosmum (3-7\%) and Weinmannia (1-6\%). LMF taxa show slightly higher proportions between $9 \%$ and $15 \%$, represented mainly by Moraceae/Urticaceae (3-8\%) and Alchornea (1-6\%) pollen. The highest proportions of pteridophyta spores up to $20 \%$ are reached in this zone due to higher values up to $6 \%$ of Huperzia spores and increasing Cyatheaceae spores from $2 \%$ to $9 \%$. Moss spores vary between $2 \%$ and $24 \%$. Isoëtes spores are sparsely present $(<1 \%)$.

\section{Magnetic susceptibility of the CT core}

Magnetic susceptibility $(\kappa)$ analysis of core CT reveals proportions of minerogenic input and can be related to the vegetation development. Although the data have low 
values not exceeding $200 \times 10^{6}$ (Fig. 2.3), there is a good correlation between changes in magnetic susceptibility and the trends in the abundance of several pollen types. Relatively high values (on average $26 \mathrm{SI} \times 10^{6}$ ) in the lower part of the core, reflecting high minerogenic input, coincide with high proportions of the Plantago rigida pollen type. After ca. 17,000 cal yr BP, decreasing $\kappa$-values are related to a decrease in minerogenic input at the time when Plantago rigida disappeared. Synchronous with the first peaks of Huperzia spores and Hypericum pollen after 2300 or 750 cal yr BP, respectively, the $\kappa$-values are higher and reach a maximum of almost $200 \mathrm{SI} \times 10^{6}$ in the upper part of the core reflecting the sand layer. The values markedly decrease above the sand layer to negative values.

\subsection{Interpretation and discussion}

\section{Environmental conditions of the LGM}

Pollen assemblages from the period between ca. 20,000-16,200 cal yr BP (zone CT-I) indicate páramo vegetation dominated by Plantago, mainly $P$. rigida, together with Apiaceae and Poaceae. The azonal páramo species $P$. rigida most likely formed cushion mires in depressions. P. rigida, along with P. australis and Huperzia, reflect locally cold and humid conditions that likely prevailed during the LGM (Cleef, 1978; Bosman et al., 1994). The low temperatures were probably responsible for the low abundance of forest taxa, suggesting that mountain rainforests were restricted to lower elevations. The UFL must have been markedly lower compared to the present. The only Andean Alder species is considered to be A. acuminata (Furlow, 1979). High pollen abundances of $A$. acuminata recorded for the LGM at Cerro Toledo are interpreted to reflect high abundances of A. acuminata trees. The same was found in records from the eastern Bolivian Andes, where it marked cold and dry conditions (Mourguiart and Ledru, 2003). At Cerro Toledo A. acuminata declined during lateglacial times, when submersed growing Isoëtes indicates a change to wetter conditions than previously. But this does not indicate explicit dry conditions for times with higher A. acuminata abundance at our study site. Since A. acuminata is also favoured by disturbances resulting in open areas like landslides (Weng et al., 2004), erosion may have facilitated the growth of $A$. acuminata. The high minerogenic content of the clayey sediment during this period suggests that the vegetation cover was not complete, resulting in unstable soils and erosion.

Glaciation apparently did not affect our study site at $3150 \mathrm{~m}$ elevation since ca. 20,000 cal yr BP, even if sufficient humidity could have facilitated glacier formation. Evidence for glacier extents during Marine Isotope Stage 2 in northern parts of Ecuador (Schubert and Clapperton, 1990; Clapperton and Seltzer, 2001; Mark et al., 2004) give only limited support for LGM glaciations in South Ecuador. Lower glacier margins at $2750 \mathrm{~m}$ a.s.l. in the Andean depression region (lat. 3-6 ${ }^{\circ} \mathrm{S}$ ) were reconstructed by geomorphologic analyses in the central area of the PNP (Rozsypal, 2000). Here cirque lakes are found at $3200 \mathrm{~m}$ elevation. Consequently, glaciers may have existed in the Cerro Toledo area until 20,000 cal yr BP.

From the beginning of the following period (16,200-14,700 cal yr BP, zone CT-II) 
páramo vegetation began to decrease while subpáramo and mountain rainforest increased. This represents an upslope shift of mountain rainforest and UFL in the study area indicating increasing temperatures. The persistent occurrence of pteridophyta and high values of Isoëtes suggest a change to wetter conditions than previously. Isoëtes, a (semi-) aquatic genus mostly occurring submerged in páramo lakes (Cleef, 1978; Bosman et al., 1994), indicates that there must have been shallow water bodies in the small basin of the study site. This is also suggested by below zero $\kappa$-values (Fig. 2.3) and higher Cyperaceae occurrence at this time, which reflect wet conditions or riverine vegetation. Likewise the wet assemblage of shrubby subpáramo vegetation composed of Melastomataceae, Asteraceae and Ericaceae suggests high moisture levels (Cleef, A., personal communication, 2008). The marked decrease of Plantago and increase of Poaceae might indicate that grass páramo surrounded the small basin.

\section{Environmental conditions of the late-glacial period}

The decrease of páramo continued from ca. 14,700-11,500 cal yr BP (zone CT-III). Plantago and Apiaceae disappeared recording a changeover to a grass páramo with alternating Poaceae and Cyperaceae. Pollen of LMF taxa (e.g., Moraceae/Urticaceae, Alchornea and Acalypha) tends to be over-represented due to wind transport to higher elevations (Bosman et al., 1994; Bush and Rivera, 2001). In our study only Moraceae/Urticaceae showed high presence, suggesting that a masking in the pollen record could be the case. Nevertheless, the conspicuous increase in LMF probably reflects slowly and continuously increasing temperatures. Persistent humid conditions suggested by high occurrences of Cyperacae and Isoëtes may be responsible for only minor upslope shift of rain forests.

\section{Environmental conditions of the Holocene}

The beginning of the Holocene (ca. 11,500 cal yr BP) is represented by a gradual change indicated by disappearance of Isoëtes, lower presence of páramo vegetation and a high proportion of subpáramo. The shallow water pond was replaced by a peat bog. During the early Holocene (ca. 11,500-8400 cal yr BP, including zone CT-III and CTB-I), relatively low proportion of páramo and highest expansion of LMF were reached between ca. 9300 and 8500 cal yr BP. Thus the highest temperatures during the last 20,000 yr were probably reached during this interval. This interpretation is supported by highly decomposed peat of the CTB core.

From ca. 8500 to 6900 cal yr BP (zone CT-IV and CTB-II), grass páramo vegetation expanded substantially while LMF decreased, suggesting a change to cooler conditions. Even though UMF presence remained relatively stable during this period, a particularly high abundance of Podocarpaceae probably reflects an upslope shift of UFL. Humid conditions persisted at the study site as pteridophyta continued to show high abundances and Sphagnum appeared for the first time.

During the mid-Holocene between ca. 6900 and 4700 cal yr BP (zone CTB-III), the abundance of subpáramo was notably higher while páramo were represented by a lower occurrence than earlier. This is interpreted to indicate a change to higher 
temperatures. However, temperatures did probably not exceed those of the warmest period between ca. 9300-8500 cal yr BP because UMF continued to persist at same abundances and Moraceae/Urticaceae occurrence was even lower as in the previous period. Persistent humid conditions are indicated by relatively high occurrence of pteridophyta and the presence of Sphagnum probably forming bogs with Xyris and grasses. After ca. 4700 cal yr BP (zone CTB-IV) the trend of páramo expansion continued under cooler conditions. The grass páramo composition was dominated by Poaceae with increasing proportions of Cyperaceae. Decreasing occurrences of subpáramo, UMF and particularly LMF suggest that the cooling continued until ca. 1800 cal yr BP.

During the late Holocene after ca. 1800 cal yr BP (zone CTB-V), a slight decrease in páramo and increase in subpáramo, UMF, and LMF suggest a change to warmer temperatures opposed to the previous interval of cooling. The very high occurrence of Moritzia (probably $M$. lindenii) dominated the páramo assemblage in the uppermost part of the CT core. Therefore, the notable páramo increase in recent times likely reflects an overrepresentation of Moritzia at the core site rather than vegetation changes (Cleef, A., personal communication, 2008). Alnus is conventionally thought to have increased simultaneous with the Holocene warming (Weng et al., 2004). In this record, however, no increase of $A$. acuminata was found with the onset of the Holocene. Because A. acuminata presence also can be a result of anthropogenic disturbances (Weng et al., 2004), we suggest rather an increase of A. acuminata caused by human impacts in the area than by climatic changes. Human disturbances are supported by higher charcoal influx in the most recent pollen zones of both cores. The fact that charcoal influx increased twice as much than pollen influx in the CT core indicates heightened fire frequency. The undisturbed sediment of CTB core shows high charcoal influx and concentration between 1550 and 1220 cal yr BP (zone CTB-V), supporting human activities in the permanent humid area. Increased fires were probably due to human fire use in slash and burn farming or hunting activities (Niemann and Behling, 2008a). However, compared to charcoal influx values of nearby study sites, for example El Tiro (Niemann and Behling, 2008b), fire activity was comparably low at Cerro Toledo. This is supported by the heightened presence of Weinmannia despite higher fire frequencies, as this genus is highly sensitive to fire (Niemann and Behling, 2009).

Another indication of human disturbance are very high occurrences of Huperzia and Hypericum at ca. $2300 \mathrm{cal}$ yr BP and ca. 750 cal yr BP (Fig. 2.3). Huperzia is a pioneer common on landslides and along road cuts on open sandy soils. Hypericum can replace degraded páramo vegetation (Cleef, A., personal communication, 2008). The synchronously increased minerogenic input may reflect erosion because of sparse vegetation favouring Huperzia and Hypericum.

\section{Vegetation history of the Podocarpus National Park area}

Environmental reconstruction for the PNP area is based on the comparison of the records presented here from the southern region at Cerro Toledo with the northernmost record from El Tiro site (Niemann and Behling, 2008b), ca. $43 \mathrm{~km}$ distant. For 
the LGM (ca. 21,000-15,800 cal yr BP) the record of El Tiro at $2800 \mathrm{~m}$ a.s.l. indicated grass páramo vegetation, mainly composed of Poaceae and Plantago reflecting cold and moist conditions. The UFL was at markedly lower elevations compared to present day. This agrees with Cerro Toledo results even though the páramo composition dominated by Plantago suggests more humidity at Cerro Toledo. Concerning the stronger signal of downslope eastern LMF at the higher elevation Cerro Toledo site, we assume that the southern part was more influenced by eastern Amazonia climates than the northern part of the PNP. Perhaps forest taxa from lower elevations had less effective (topographic) barriers allowing them to reach Cerro Toledo. Indications for slowly warming conditions were found at El Tiro from ca. 11,200 cal yr BP onwards. This is later than at the Cerro Toledo site, where first evidence of slightly rising temperatures occurred at 16,200 cal yr BP.

Páramo vegetation decreased continuously and almost disappeared during thewarming interval at El Tiro, while UMF vegetation expanded from ca. 89003300 cal yr BP. After 3300 cal yr BP, modern subpáramo vegetation became established. Hence, the period from 8900-3300 cal yr BP was warmer and drier than the present at El Tiro. At Cerro Toledo, highest temperatures probably occurred between 9300 and $8500 \mathrm{cal} \mathrm{yr} \mathrm{BP.} \mathrm{Thus,} \mathrm{both} \mathrm{lines} \mathrm{of} \mathrm{evidence} \mathrm{suggest} \mathrm{that} \mathrm{the} \mathrm{highest}$ temperatures in the region were reached in the early Holocene.

For both sites, rare fires were recorded during the LGM and higher fire frequencies during the Holocene. At El Tiro fires began to increase already since 8000 cal yr BP and highest frequencies occurred since 3300 cal yr BP. Increased fire frequency at Cerro Toledo was indicated since $1550 \mathrm{cal}$ yr BP. Fires during the late Holocene at both sites are suggested to be mostly of anthropogenic origin. However, El Tiro was probably more disturbed than the Cerro Toledo region as fires increased earlier and stronger.

\section{Regional integration of the environmental history at Cerro Toledo}

Cerro Toledo, located in the eastern Andes between the Amazonian basin and the western Andes, could experience both Pacific-type climates (from the west) and Amazonian-type climates (from the east). The present-day climate at the study site, with strong easterlies and particularly high precipitation, indicates a greater influence of Amazonian climates than Pacific. The eastern slopes thus appear sheltered from Pacific climates by the Andes. For the reconstruction of past conditions, however, further comparisons have to be made and vegetation changes of different sites have to be considered (Table 2.4). At first, two records at the western Cordillera allow a regional comparison. Lake Surucucho, ca. $150 \mathrm{~km}$ north from Cerro Toledo lies almost at the same altitude (3180 $\mathrm{m}$ a.s.l.). The record shows treeless vegetation during glacial times, an upslope advance of UFL in the late-glacial period, and the development of Andean forest during the Holocene (Colinvaux et al., 1997). Obviously forest could establish at a greater altitude than in the PNP area, and the UFL was located at higher elevations already during the early Holocene.

Furthermore, the signal of UFL shift is less evident in the PNP area than at other sites where the typical proxy Polylepis dominates the UFL. Studies from the 
southwestern Ecuadorian Cordillera at Laguna Chorreras (ca. $3700 \mathrm{~m}$ a.s.l.) indicate that Polylepis replaced other taxa during the Holocene and reached its maximum during the mid- Holocene period, reflecting a strong signal for UFL shift (Hansen et al., 2003).

A shift of UFL to higher elevations during the mid-Holocene at the Cerro Toledo is indicated by notably high presence of Podocarpaceae, even though other taxa (e.g., Weinmannia or Hedyosmum) constituting the UFL ecotone did not increase. This suggestion is supported by results of the El Tiro site inside the PNP, where the UFL shifted upslope after 8900 cal yr BP (Niemann and Behling, 2008b). The weaker signal of UFL shift in the PNP area can originate from the absence of Polylepis, due to high precipitation and strong winds, or reflect minor fluctuations of past UFL shifts. Hence, variant forest development and UFL positions reveal major differences between the western and eastern Cordillera, which is mainly due to different climatic conditions.

Records from the Ecuadorian Amazon basin are few and far between (Table 2.4). During the late Pleistocene (ca. 30,000-26,000 yr BP) at San Juan de Bosco (Bush et al., 1990) and the Mera site (Liu and Colinvaux, 1985), mixed lowland and mountain forest communities were present at ca. $1000 \mathrm{~m}$ elevation. During the late Holocene, flooding of the western Amazonia (ca. 1300-800 cal yr BP) was interpreted as a consequence of increased precipitation in the northeastern Andes. Accordingly, there is a certain connectivity of the eastern Andes and the Amazon basin. At Cerro Toledo no concurrent events were identified to the dry periods observed in western Amazonia during the mid- and late Holocene at Lake Ayauch ${ }^{i}$ and Kumpak ${ }^{a}$ (Bush and Colinvaux, 1988; Liu and Colinvaux, 1988). However, the drier climates only affected some lowland taxa and did not implicate a major forest change. Therefore it is likely that the dry periods of the Amazonian basin may not have affected the upper slopes and highland taxa of the eastern Andes. Despite the poor information available from the Amazon basin, a linkage between the eastern Cordillera and the Amazonia is much more appropriate even in the past than between the eastern and western Andes. 


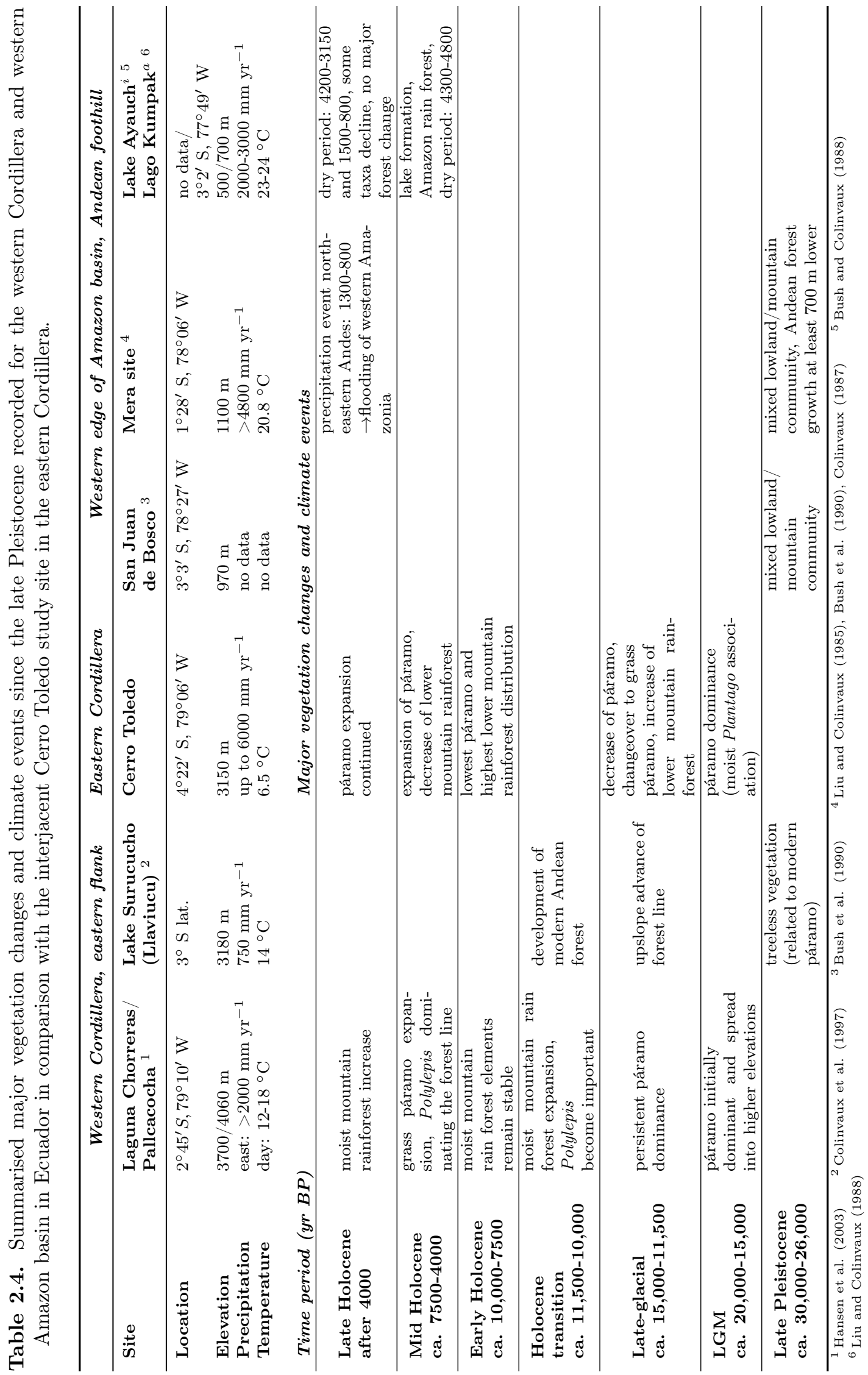




\subsection{Conclusions}

The two records at Cerro Toledo provide a detailed vegetation reconstruction including fire and climate history during the last 20,000 cal yr BP. The study site was not covered by glaciers at $3150 \mathrm{~m}$ elevation during the recorded period, even though it was persistently humid. However, páramo vegetation dominated by Plantago at the beginning of the record could have developed in moist and cold places following glacial retreat, which means glaciers could have existed before the recorded time. The transition to the Holocene was a gradual change with slow warming. Highest temperatures were probably reached in the early Holocene between 9300 and 8500 cal yr BP. Increasing temperatures and the expansion of mountain rainforest during the Holocene caused an upslope UFL shift, but not consequent shifts of all vegetation types within the broad vegetation belts. The present peat bog with high proportions of Sphagnum began to develop during the mid-Holocene. Indications of human disturbances are found since ca. 2300 cal yr BP, but the study site was comparatively little affected by anthropogenic impact during the past. It can be concluded that regional climate dynamics influenced the vegetation development over time in the PNP area. Continuous, very humid conditions of the study area indicate that the regionwas mostly influenced by eastern Amazonian-type climates. However, local site characteristics like slope and aspect can explain differences in microclimates between the sites that gave rise to differences in the local vegetation development through time. Furthermore, the Andean barriers for climatic conditions and upslope-moving taxa from the Amazon basin seem to be less effective in the southern part of the PNP area than in the northern part. Hence, the cordilleras presented not absolute but nonetheless considerable barriers for plant dispersal.

\subsection{Acknowledgements}

The authors thank the Deutsche Forschungsgemeinschaft (DFG) for financial support (BE 2116/8-1). The research unit FOR 816 is thanked for the logistic support. We acknowledge the scientific discussions with Torsten Haberzettl, Antoine Cleef and Michael Richter. Vera Markgraf and Thomas Gieseke are kindly thanked for their critical review and improvement of the manuscript. Thanks go to the University of Bremen (Geosciences) for measuring the magnetic susceptibility. For supporting the field work Achim Bräuning and Holger Niemann are thanked.

\subsection{References}

Bakker, J., Moscol Olivera, M., Hooghiemstra, H., 2008. Holocene environmental change at the upper forest line in northern Ecuador. The Holocene 18, 1-17.

Beck, E., Bendix, J., Kottke, I., Makeschin, F., Mosandl, R. (Eds.), 2008a. Gradients in a Tropical Mountain Ecosystem of Ecuador. Ecological Studies 198. Springer, Berlin, Heidelberg. 525 pp. 
Beck, E., Makeschin, F., Haubrich, F., Richter, M., Bendix, J., Valerezo, C., 2008b. The Ecosystem (Reserva Biológica San Francisco). In: Beck, E., Bendix, J., Kottke, I., Makeschin, F., Mosandl, R. (Eds.), 2008a. Gradients in a Tropical Mountain Ecosystem of Ecuador. Ecological Studies 198. Springer, Berlin, Heidelberg, pp. 1-13.

Beck, E., Kottke, I., Bendix, J., Makeschin, F., Mosandl, R., 2008c. Gradients in a tropical mountain ecosystem - a synthesis. In: Beck, E., Bendix, J., Kottke, I., Makeschin, F., Mosandl, R. (Eds.), 2008a. Gradients in a Tropical Mountain Ecosystem of Ecuador. Ecological Studies 198. Springer, Berlin, Heidelberg, pp. 451-463.

Behling, H., 1993. Untersuchungen zur spätpleistozänen und holozänen Vegetations und Klimageschichte der tropischen Küstenwälder und der Araukarienwälder in Santa Catarina (Südbrasilien). Dissertationes Botanicae 206, Cramer, Berlin, Stuttgart, 149 pp.

Bendix, J., Rollenbeck, R., Richter, M., Fabian, P., Emck, P., 2008a. Climate. In: Beck, E., Bendix, J., Kottke, I., Makeschin, F., Mosandl, R. (Eds.), 2008a: Gradients in a Tropical Mountain Ecosystem of Ecuador. Ecological Studies 198. Springer, Berlin, Heidelberg, pp. 63-73.

Bendix, J., Rollenbeck, R., Fabian, P., Emck, P., Richter, M., Beck, E., 2008b. Climate variability. In: Beck, E., Bendix, J., Kottke, I., Makeschin, F., Mosandl, R. (Eds.), 2008a: Gradients in a Tropical Mountain Ecosystem of Ecuador. Ecological Studies 198. Springer, Berlin, Heidelberg, pp. 281-290.

Bosman, A.F., Hooghiemstra, H., Cleef, A.M., 1994. Holocene mire development and climatic change from high Andean Plantago rigida cushion mire. The Holocene 3, 233-243.

Bush, M.B., Colinvaux, P.A., 1988. A 7000-year pollen record from the Amazon lowlands, Ecuador. Vegetatio 76, 141-154.

Bush, M.B., Rivera, R., 2001. Reproductive ecology and pollen representation among neotropical trees. Global Ecology and Biogeography 10, 359-367.

Bush, M.B., Colinvaux, P.A., Wiemann, M.C., Piperno, D.R., Liu, K.B., 1990. Late Pleistocene temperature depression and vegetation change in Ecuadorian Amazonia. Quaternary Research 34, 330-345.

Clapperton, C.M., Seltzer, G.O., 2001. Glaciation during marine isotope stage 2 in the American Cordillera. In: Markgraf, V. (Ed.), 2001. Interhemispheric Climate Linkages. Academic Press, pp. 173-181.

Cleef, A.M., 1978. Characteristics of neotropical paramo vegetation and its subantarctic relations. In: Troll, C., Lauer, W. (Eds.), 1978. Geoecological Relations between the Southern Temperate Zone and the Tropical Mountains. Erdwissenschaftliche Forschung XI. Franz Steiner, Wiesbaden, pp. 365-390. 
Colinvaux, P.A., 1987. Amazon diversity in light of the paleoecological record. Quaternary Science Reviews 6, 93-114.

Colinvaux, P.A., Frost, M., Frost, I., Liu, K.-B., Steinitz-Kannan, M., 1988a. Three pollen diagrams of forest disturbance in the western Amazon basin. Review of Palaeobotany and Palynology 55, 73-81.

Colinvaux, P.A., Olson, K., Liu, K.-B., 1988b. Late-Glacial and Holocene pollen diagrams from two endorheic lakes of the inter-Andean Plateau of Ecuador. Review of Palaeobotany and Palynology 55, 83-99.

Colinvaux, P.A., Bush, M.B., Steinitz-Kannan, M., Miller, M.C., 1997. Glacial and postglacial pollen records from the Ecuadorian Andes and Amazon. Quaternary Research 48, 69-78.

Emck, P., 2007. A Climatology of South Ecuador - With Special Focus on the Major Andean Ridge as Atlantic-Pacific climate Divide. Dissertation, Universität Erlangen- Nürnberg.

Fægri, K., Iversen, J., 1989. Textbook of Pollen Analysis, 4th ed. Wiley, Chichester. 328 pp.

Furlow, J.J., 1979. The systematics of the American species of Alnus (Betulaceae). Rhodora 81, 1-121.

Grimm, E.C., 1987. CONISS: a Fortran 77 program for stratigraphically constrained cluster analysis by the method of the incremental sum of squares. Computer and Geosciences 13, 13-35.

Hansen, B.C., Rodbell, D.T., Seltzer, G.O., León, B., Young, K.R., Abbott, M., 2003. Lateglacial and Holocene vegetation history from two sites in the western Cordillera of southwestern Ecuador. Palaeogeography, Palaeoclimatology, Palaeoecology 194, 79-108.

Homeier, J., Werner, F.A., Gradstein, S.R., Breckle, S.-W., Richter, M., 2008. Potential vegetation and floristic composition of Andean forests in South Ecuador, with a focus on the RBSF. In: Beck, E., Bendix, J., Kottke, I., Makeschin, F., Mosandl, R. (Eds.), 2008a: Gradients in a Tropical Mountain Ecosystem of Ecuador. Ecological Studies 198. Springer, Berlin, Heidelberg, pp. 87-100.

Hooghiemstra H., 1984. Vegetation and climatic history of the High Plain of Bogota, Colombia: a continuous record of the last 3,5 million years. Dissertationes Botanicae 79, Cramer, Vaduz, 368 pp.

Josse, C. (Ed.), 2001. La biodiversidad de Ecuador. Informe 2000. Ministerio de Ambiente, EcoCiencia y UICN, Quito, 368 pp.

Kessler, M., 1995. Polylepis-Wälder Boliviens: Taxa, Ökologie, Verbreitung und Geschichte. Dissertationes Botanicae 246, Berlin, Stuttgart. 
Liu, K.-B., Colinvaux, P.A., 1985. Forest changes in the Amazon Basin during the last glacial maximum. Nature 318, 556-557.

Liu, K.-B., Colinvaux, P.A., 1988. A 5200-year history of Amazon rain forest. Journal of Biogeography 15, 231-248.

Lozano, P., Delgado, T., Aguirre, Z., 2003. Estado actual de la flora endemica exclusive y su distribucion en el Occidente del Parque Nacional Podocarpus. Funbotanica y Herbario y Jardin Botanico. Loja, Ecuador.

Mark, B.G., Seltzer, G.O., Rodbell, D.T., 2004. Late Quaternary glaciations of Ecuador, Peru and Bolivia. In: Ehlers, J., Gibbard, P.L. (Eds.), 2004. Quaternary Glaciations - Extent and Chronology, Part III: South America, Asia, Africa, Australasia, Antarctica: Developments in Quaternary Science, 2, pp. 151-163.

Mourguiart, P., Ledru, M.-P., 2003. Last Glacial Maximum in an Andean cloud forest environment (Eastern Cordillera, Bolivia). Geology 31, 195-198.

Mutke, J., Barthlott,W., 2005. Patterns of vascular plant diversity at continental to global scales. Biologiske Skrifter 55, 521-531.

Niemann, H., Behling, H., 2008a. Past vegetation and fire dynamics. In: Beck, E., Bendix, J., Kottke, I., Makeschin, F., Mosandl, R. (Eds.), 2008a: Gradients in a Tropical Mountain Ecosystem of Ecuador. Ecological Studies 198. Springer, Berlin, Heidelberg, pp. 101-111.

Niemann, H., Behling, H., 2008b. Late Quaternary vegetation, climate and fire dynamics inferred from the El Tiro record in the southeastern Ecuadorian Andes. Journal of Quaternary Science 23, 203-212.

Niemann, H., Behling, H., 2009. Late Pleistocene and Holocene vegetation development, climate variability and human impact inferred from Cocha Caranga multi-proxy records in the southeastern Ecuadorian Andes. Palaeogeography, Palaeoclimatology, Palaeoecology 276, 1-14.

Niemann, H., Haberzettl, T., Behling, H., 2009. Holocene climate variability and vegetation dynamics inferred from the (11,700 cal yr BP) Laguna Rabadilla de Vaca sediment record in the southeastern Ecuadorian Andes. The Holocene 19, 307-316.

Richter, M., Moreira-Muñoz, A., 2005. Climatic heterogeneity and plant diversity in southern Ecuador experienced by phytoindication. Review of Peruvian Biology $12,217-238$.

Richter, M., Diertl, K.-H., Peters, T., Bussmann, R.W., 2008. Vegetation structures and ecological features of the upper timberline ecotone. In: Beck, E., Bendix, J., Kottke, I., Makeschin, F., Mosandl, R. (Eds.), 2008a. Gradients in a Tropical 
Mountain Ecosystem of Ecuador. Ecological Studies 198. Springer, Berlin, Heidelberg, pp. 123-135.

Rozsypal, A.A., 2000. Die pleistozäne Glazialmorphologie in Ecuador und Nordperu unter besonderer Betrachtung der Cordillera Oriental bei Loja. Diplomarbeit, Institut für Geographie, Universität Erlangen-Nürnberg (unpublished).

Schubert, C., Clapperton, C.M., 1990. Quaternary Glaciations in the Northern Andes (Venezuela, Colombia and Ecuador). Quaternary Science Reviews 9, 123-135.

Weng, C., Bush, M.B., Athens, J.S., 2002. Holocene climate change and hydrarch succession in lowland Amazonian Ecuador. Review of Palaeobotany and Palynology 120, 73-90.

Weng, C., Bush, M.A., Chepstow-Lusty, A.J., 2004. Holocene changes of Andean alder (Alnus acuminata) in highland Ecuador and Peru. Journal of Quaternary Science 19, 685-691.

Weninger, B., Jöris, O., Danzeglocke,U., 2004. Calpal: The Cologne radiocarbon CALibration and PALaeoclimate research package. URL :http://www.calpal.de [10 April 2008]. 



\title{
Chapter 3.
}

\section{High-resolution studies on vegetation succession, hydrological variations, anthropogenic impact and genesis of a subrecent lake in southern Ecuador}

\author{
Brunschön, C., Haberzettl, T. and Behling, H. \\ Vegetation History and Archaeobotany 19 (2010) 191-206
}

\subsection{Abstract}

A lake sediment record from Laguna Campana at 2,488 $\mathrm{m}$ a.s.l. in the eastern Ecuadorian Andes allows the reconstruction of local environmental conditions over the past $\sim 500$ years. A high-resolution multi-proxy approach using pollen, spore, charcoal and $\mathrm{XRF}$ analyses provides information about lake genesis, hydrological variations and the development of the surrounding vegetation. Results suggest that Laguna Campana originated from a landslide, which are naturally common and anthropogenically promoted in the study area. Human activities, e.g. deforestation or slash and burn cultivation, impacted the local vegetation development and biodiversity during the recorded period. After a first dense layer of pioneer grasses developed on open soil around the small lake, successional stages of secondary upper mountain rainforest forest mainly composed of Alnus and Weinmannia were observed. The record shows no signs of dense forest regeneration but rather open vegetation with trees and a grassy understory. Especially since ca. A.D. 1980, the proportion of forest in the area was reduced, most probably by fire use for pastures, cultivation and wood extraction. Hydrological variability was derived from differences in minerogenic input and variations in Botryococcus braunii and Sphagnum occurrence. After wettest conditions at the study site, probably triggering the landslide, humid conditions persisted until a time of drier conditions between A.D. 1900 and 1960. A subsequent return to wetter conditions was observed over the last decades. XRF analyses suggest an increase in deposition of atmospherically derived lead since the formation of the lake.

Keywords: Multi-proxy, Pollen, Vegetation history, Anthropogenic impact, Lead, Hydrological variability, Ecuadorian Andes 


\subsection{Introduction}

Tropical mountain regions, as occur in the eastern Andes of Ecuador, are emphasized as holding the world's most significant biodiversity hotspots (Barthlott et al. 2005). Different environmental conditions are responsible for this phenomenon. Among the triggers of biodiversity, for example the complex topography and highly varied climatic conditions can be specified for the Andean region. Additionally, the uplift of mountain chains causing an extensive evolutionary radiation should be considered in terms of species richness and biodiversity levels (Richter 2008). Hence, tropical mountain ecosystems and their origin play an important role in biodiversity research. However, palaeoecological records in mountain forests of the Andean region are thinly scattered not least because of the steep slopes and scarcity of natural archives (Bush et al. 2007). The first palynological studies in the eastern Ecuadorian Andes focusing on the Podocarpus National Park (PNP) and its megadiverse mountain ecosystems have been carried out recently (Beck et al. 2008a). Several palaeoecological analyses of sediment cores at high elevations up to 3,300 $\mathrm{m}$ a.s.l. were used to begin a comprehensive reconstruction of late Quaternary vegetation of the PNP (Brunschön and Behling 2009; Niemann and Behling 2008a, b; Niemann and Behling 2009, 2010; Niemann et al. 2009).

Within the South American countries Ecuador currently suffers from the highest deforestation rate of 198,000 ha year $^{-1}$ (FAO 2006). Already during pre-Columbian times a long-lasting deforestation in the mountain regions had contributed to the reduction of forest areas (Wunder 2000). Early human settlements were accompanied by land use for cultivation and pastures, converting natural landscapes into man-made environments on a large scale. During the most recent times agricultural colonization due to increasing population is further amplified by infrastructure improvements (Pohle 2008). Extensive road construction and other anthropogenic factors additionally promote wide-spread landslides in the Ecuadorian Andes, which are also naturally triggered, for example by unstable slopes and perhumid environmental conditions (Lozano et al. 2005). The landslides are assumed to play an important role in maintaining species diversity in tropical mountain forests (Guariguata 1990; Kessler 1999).

This study focuses on environmental and vegetation dynamics of mountain ecosystems in the area of the Podocarpus National Park. High-resolution multi-proxy palaeoecological analyses of the Laguna Campana sediment record (Fig. 3.1) are used to provide detailed insights into palaeoenvironmental variations. This will allow the identification of possible past human influences and their potential impacts on local vegetation and biodiversity.

\subsection{Study site}

\section{Location}

Laguna Campana $\left(04^{\circ} 01^{\prime} 28^{\prime \prime} \mathrm{S}, 79^{\circ} 10^{\prime} 40^{\prime \prime} \mathrm{W}\right)$ is located on the western slope of the Cordillera Real, an eastern Andean range of Southern Ecuador at an elevation of 


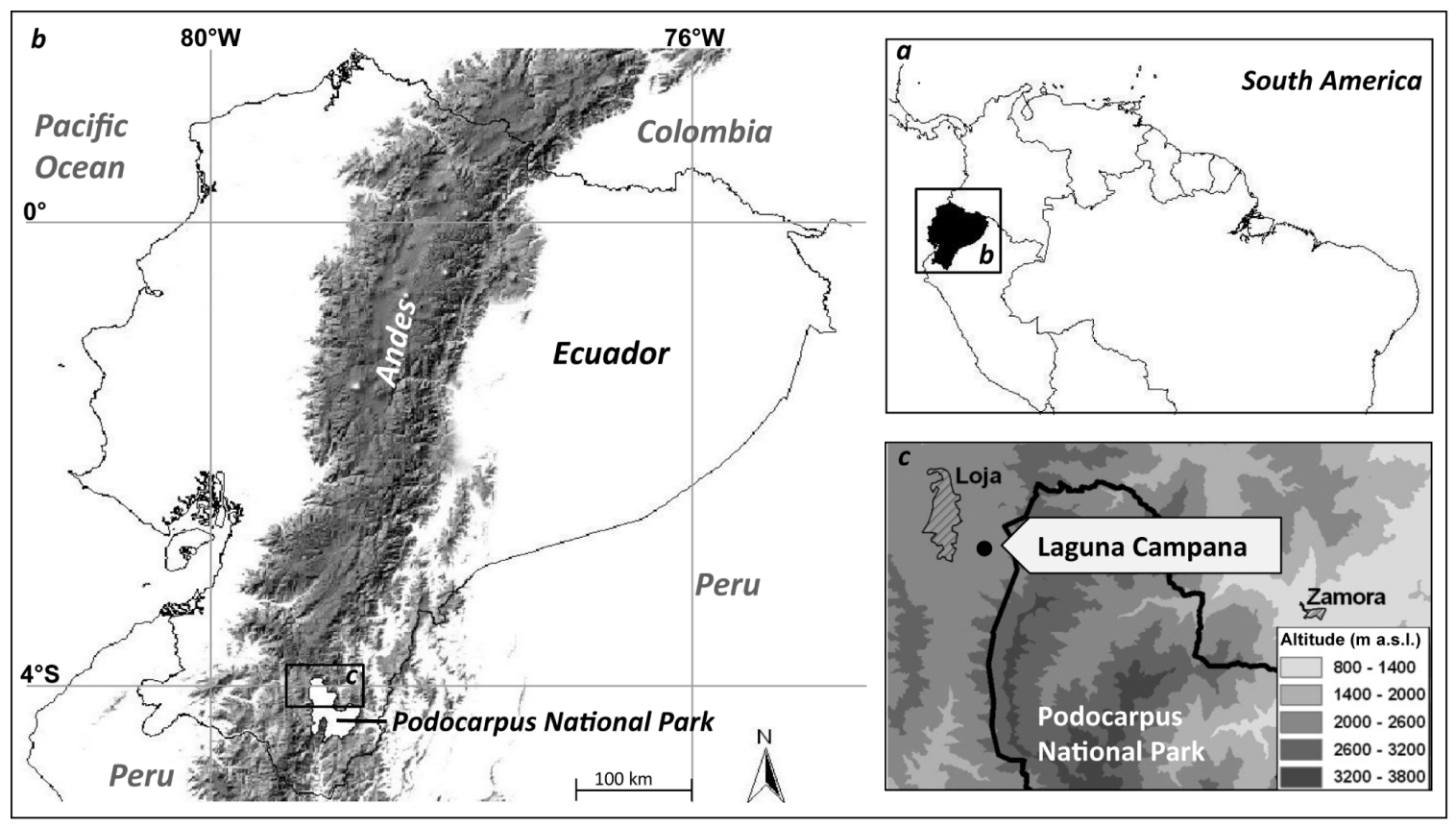

Figure 3.1. Map showing (a) the location of Ecuador in South America, (b) the Andes (shaded area) and the limits of the Podocarpus National Park and (c) a detailed sketch of the research area between the cities of Loja and Zamora. The study site Laguna Campana is located at $2488 \mathrm{~m}$ a.s.l. west of the northern Podocarpus National Park area.

2,488 m a.s.l. (Fig. 3.1). Nearby crests reach elevations of up to $\sim 3,100 \mathrm{~m}$. The study area is about $5 \mathrm{~km}$ southeast of the city of Loja (2,100 $\mathrm{m}$ a.s.l., Fig. 3.1) and $2 \mathrm{~km}$ west of the Podocarpus National Park (PNP), which is located between the provinces of Loja and Zamora-Chinchipe. The small village of Zamora Huayco Alto is situated west of Laguna Campana about $300 \mathrm{~m}$ downhill. Observations of surrounding geomorphologic structures suggest that Laguna Campana was probably formed by a landslide the age of which is, hitherto, unknown. Nowadays, the small lake neither has an inflow nor an outflow. It has a maximum water depth of $1.5 \mathrm{~m}$ and covers an area of about $1,500 \mathrm{~m}^{2}$.

\section{Geomorphology and geology}

The so called Girón-Cuenca and Huancabamba Andean depression region in the eastern Andean range of southern Ecuador and northern Peru $\left(2-6^{\circ} \mathrm{S}\right)$ is characterised by low elevations not exceeding 4,000 m a.s.l. (Richter and Moreira-Muñoz 2005). Volcanoes as well as glaciers are absent (Schubert and Clapperton 1990). Hence, volcanic contributions to the sediments of Laguna Campana are negligible. The area of the Andean depression, where the study site is located, consists of a complicated topography as a junction of mountain ranges culminates in the so called "Nudo de Loja", from which Inter-Andean Sierras stretch in different directions dissected by valleys and basins (Beck et al. 2008b). The eastern Andean Cordillera is mainly made up of Paleozoic metamorphic rocks (Baldock 1982). Rocks around Loja consist of mica schists, gneisses and granites. The basin margins contain conglomerates of 
metamorphic debris and argillaceous sandstone in the Miocene layers, which promote landslides of water saturated soils (Sauer 1971). Landslides in the tropical mountain forests of Ecuador are mostly shallow soil removals. Often only O-horizons and upper parts of the A-horizons are displaced further downslope (Bussmann et al. 2008). Geomorphologic evidence for landslides can be observed all around the study site including Laguna Campana.

\section{Climate}

The climate of Ecuador including the study area is dominated by the tropical trade wind regime characterised by strong easterlies bringing moist air masses from the Amazon basin (Beck et al. 2008b). The Cordillera Real acts as a climatic divide separating moist conditions on the Amazon exposed eastern side from the (semi-) arid climate on the west (Emck 2007). East of the Cordillera, precipitation and humidity rise continuously to the crest regions. The western escarpment and the Inter-Andean zone belong to the greater lee of the Cordillera Real, where arid conditions start immediately behind the climate divide. Rainfall of $6,000 \mathrm{~mm} \mathrm{a}^{-1}$ at 3,100 $\mathrm{m}$ a.s.l. contrasts with the Inter-Andean basin, which receives generally less than 1,000 mm a ${ }^{-1}$ (Emck 2007; Bendix et al. 2008a). As Laguna Campana is located on the western slopes of Cordillera Real it faces the dry Inter-Andean basin (Fig. 3.1). Rainfall variability reveals a diurnal and seasonal pattern in the study area. Variations caused by ENSO (El Niño-Southern Oscillation) do not have an influence as the region is sheltered from Pacific air masses by the mountain ranges (Bendix et al. 2008b).

Temperature varies according to the time of day and season. The austral winter is the wettest and coldest period of the year (Bendix et al. 2008a). Laguna Campana is situated between the so called "tierras templadas and frescas" (temperate and cool land), where soil temperature of ca. $15{ }^{\circ} \mathrm{C}$ and 9-12 humid months are observed. Measurements at Loja (2,160 m a.s.l., $2.5 \mathrm{~km}$ from Laguna Campana) indicate a mean annual precipitation of $922-947 \mathrm{~mm}$ and a mean annual temperature of $15.5^{\circ} \mathrm{C}$ (Richter and Moreira-Muñoz 2005; Günter et al. 2008).

\section{Modern vegetation}

The potential vegetation in the PNP area was described by Homeier et al. (2008) and citations therein (e.g. Lozano 2002; Aguirre et al. 2003; Richter 2003). Accordingly, five of the potential natural vegetation types describe the area surrounding Laguna Campana best: lower and upper mountain rainforest, interandean semideciduous forest, subpáramo and páramo. The study site and large areas in the provinces of Loja and Zamora-Chinchipe surrounding the PNP are degraded. The natural vegetation has been modified by anthropogenic activities such as road construction, deforestation, fire use and pastures.

Lower mountain rainforest (LMF) with a canopy height of $30 \mathrm{~m}$ is found at ca. 1,3002,100 m a.s.l. on the eastern escarpment of the Cordillera Real. Characteristic species are among others Cyathea caracasana, Morus insignis, Piper sp., Mikania sp. and 
Heliocarpus americanus.

Laguna Campana is located in the potential vegetation type of upper mountain rainforest (UMF) between ca. 2,400-2,700 $\mathrm{m}$ a.s.l. on the western escarpment above Loja. The canopy attains heights of up to $20 \mathrm{~m}$. Some of the main key species are Hedyosmum racemosum, Weinmannia sp., Myrica pubescens, Myrsine andina, Prumnopitys montana, Clusia sp. and Cedrela montana. It was observed in the field that the vegetation in the area frequently burned, promoting sparse shrubland dominated by burnt Puya plants on open soils. Pinus is found in the surroundings. The UMF on the eastern escarpment (ca. 2,100-2,700 $\mathrm{m}$ a.s.l.) varies in species composition and reaches a canopy height of up to $25 \mathrm{~m}$. Some key species which differ from those of the western slope are, e.g. Ilex rimbachii, Purdiaea nutans, Macrocarpaea revoluta, Podocarpus oleifolius and Dioicodendron dioicum.

At ca. 2,700-3,100 m a.s.l. on the eastern and western escarpment subpáramo vegetation is present, including a subtype of elfin forest forming the upper forest line ecotone. Canopy heights are 6-8 m and for the subpáramo a little less. Characteristic species are, e.g. Clethra ovalifolia, Gaultheria reticulata, Gaiadendron punctatum, Graffenrieda harlingii and Hesperomeles ferruginea.

Páramo (including shrub and herb páramo) is found above the upper forest line at ca. 3,100-3,600 m elevation. Páramo vegetation is characterised by a maximum height of $2 \mathrm{~m}$. Some key species are Puya eryngioides, Rhynchospora vulcani, Chusquea neurophylla, Monnina arbuscula and Valeriana microphylla.

South-west of the study site in the basin at ca. 1,400-2,400 $\mathrm{m}$ a.s.l. interandean semideciduous forest (SDF) is found. The canopy height reaches $15 \mathrm{~m}$, occasionally about $20 \mathrm{~m}$. Some indicator species are Ceiba insignis, Croton wagneri, Acacia macracantha, Anadenanthera colubrine and Dodonaea viscosa.

\subsection{Materials and methods}

For sediment sampling in the centre of Laguna Campana two different corers were used from a fixed rubber dinghy. The upper $20 \mathrm{~cm}$ of unconsolidated, water saturated sediment were recovered using an UWITEC Corer (http://www.uwitec.at/). Every $2 \mathrm{~cm}$ subsamples of sediment were taken in the field. Subsequently, a core of $82 \mathrm{~cm}$ was taken with a Livingstone piston corer from 15 to $97 \mathrm{~cm}$ depth of sediment. This sediment section was recovered in an aluminum tube and stored under dark and cold $\left(4{ }^{\circ} \mathrm{C}\right)$ conditions until processing.

Subsamples for pollen analysis were taken at $2 \mathrm{~cm}$ intervals except for a $1 \mathrm{~cm}$ sampling interval in the transition zone between the two different core sections (14$19 \mathrm{~cm}$ ). In total 52 subsamples were processed applying standard pollen analytical methods (Fægri and Iversen 1989). Exotic Lycopodium spores were added as a marker to each subsample for calculation of concentrations. The pollen sum of a minimum of 300 pollen grains includes pollen of trees, shrubs and herbs as well as unknown and indeterminate pollen types. Based on this sum percentage data of each pollen type were calculated. Spores and algae (e.g. Botryococcus braunii) were also counted and quantified as percentages of the pollen sum. Charcoal particles $(5-150 \mu \mathrm{m})$ were 
counted on each pollen slide and presented as percentage data relative to the pollen sum. Additional concentration data were calculated for Botryococcus braunii, the pollen sum and charcoal particles.

Pollen and spore identification was mainly based on the reference collection kept at the University of Göttingen, which contains 3,000 Neotropical (Behling 1993) and approximately 300 Ecuadorian pollen and spore types, and a published pollen reference from Colombia (Hooghiemstra 1984). Identified pollen types were classified in ecological groups referring to described potential natural vegetation types of the area by Homeier et al. (2008) and available data on plant ecology and distribution (Bussmann 2001; Lozano 2002; Marchant et al. 2002; Richter and Moreira-Muñoz 2005; Homeier and Werner 2008). Indicators of cultivation and plantation as well as unknown pollen types were grouped separately.

For pollen data calculation and illustration the software TILIA and TILIAGRAPH (Grimm 1991, 2004) was used. Classification of zones was based on a constrained clusters analysis of all pollen taxa performed by CONISS (Grimm 1987) and on changing abundances of the most important pollen taxa. A further subdivision of one zone was supported by significant variations in XRF data.

Non-destructive XRF-scanning was done using an ITRAX core scanner (Croudace et al. 2005; St-Onge et al. 2007) with a $1 \mathrm{~mm}$ step size. Element count rates are given in element peak areas (pa, element integral). The X-ray radiography was obtained with the same device. Subsequently, a principle component analysis (PCA) was done using log transformed values of all elements showing a mean of more than 100 pa (Fig. 3.2). Values of PC1 were multiplied by -1 in order to facilitate the comparison with the curves contributing to this PC.

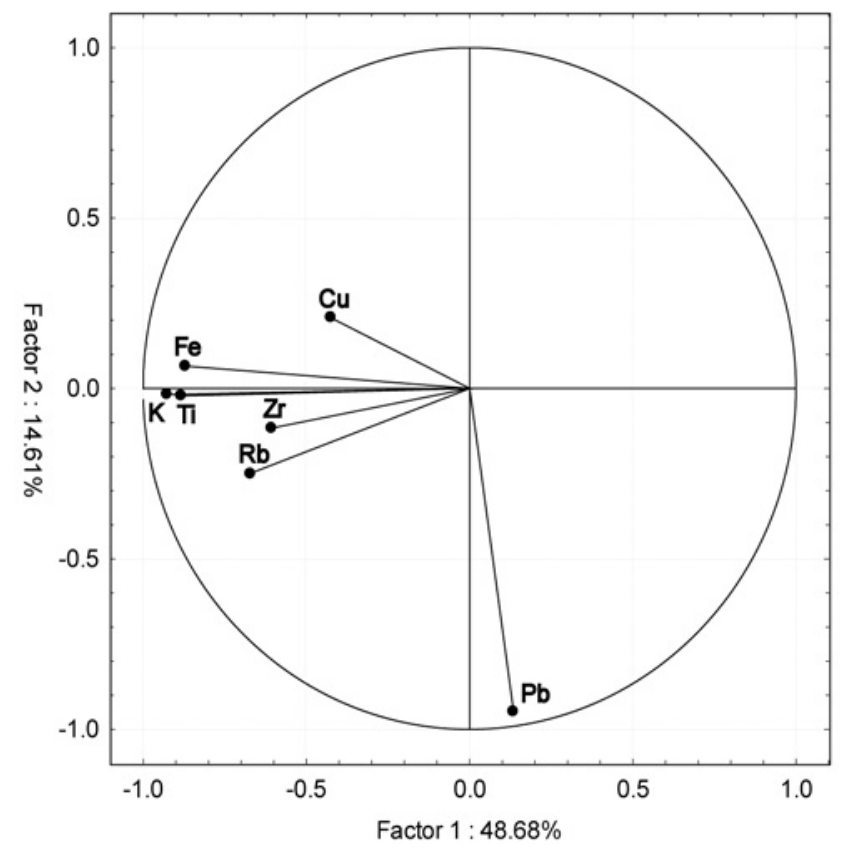

Figure 3.2. Principle Component Analysis (PCA) of all elements showing an average above 100 pa (peak area). 
PC1 reduces all the allochthonous minerogenic input parameters hitherto frequently used in other studies, such as the conservative lithogenic metal Ti (Shotyk et al. 2001; Haberzettl et al. 2005, 2006, 2007, 2008; Niemann et al. 2009) or Rb (Guyard et al. 2007), to one proxy. Hence, increases in that proxy represent an increase in runoff or eolian supply. Alternatively, PC1 mirrors the plant coverage in the catchment area. Low coverage especially immediately after a landslide would result in intensified erosion and therefore increased minerogenic input to the lake.

The incoherent/coherent (inc/coh) ratio may be used as an estimate of sediment organic content (Guyard et al. 2007; Rolland et al. 2008). This explains the opposite pattern of this ratio to $\mathrm{PC} 1$. If the minerogenic content decreases the relative proportion of organic material rises and vice versa.

Due to its stability and high resistance to chemical weathering, Ti is widely used in geochemical studies as a conservative metal, against which relative enrichments and depletions of more mobile major and trace elements like $\mathrm{Fe}, \mathrm{Pb}$ or $\mathrm{Cu}$ may be compared (Shotyk et al. 2001). The Fe/Ti ratio is a measure of redox processes. If the ratio is constant the Fe content resembles the minerogenic input and an influence of redox processes on this element is rather unlikely. For iron the critical Eh for reduction of $\mathrm{Fe}^{3+}$ compounds to more soluble $\mathrm{Fe}^{2+}$ compounds is $100 \mathrm{mV}$ (Sigg and Stumm 1996). Therefore, if the redox potential drops to values below $100 \mathrm{mV}, \mathrm{Fe} / \mathrm{Ti}$ ratios will decrease. If the migrating Fe ions oxidize again they will stop migrating and increase the $\mathrm{Fe} / \mathrm{Ti}$ ratio.

$\mathrm{Pb}$ is a measure of the lead content of the sediment relative to sediments deposited above or below. In contrast, the $\mathrm{Pb} / \mathrm{Ti}$ and $\mathrm{Cu} / \mathrm{Ti}$ ratio reflect the $\mathrm{Pb}$ and $\mathrm{Cu}$ input relative to the minerogenic input. This means that if the ratios are not constant the changes are either caused by variations in atmospheric deposition independent of eolian and fluvial input, or by displacement of ions within the profile.

For AMS radiocarbon dating three subsamples, one bulk sample from the bottom of the record and two small leaves further up in the core, were submitted to the University of Erlangen-Nürnberg, Germany and to the Poznan Radiocarbon Laboratory, Poland (Table 3.1). For calibration of the ${ }^{14} \mathrm{C}$ dates the online program CALIB 5.0.2 (Stuiver and Reimer 1993) with the Southern Hemisphere calibration set shcal04 (McCormac et al. 2004) was used. The calibrated dates given reflect the median ages of the 2- $\sigma$ distribution, as a single robust estimate, such as the weighted average or median, should be used (Telford et al. 2004).

\subsection{Results}

\section{Lithology}

Macroscopic inspections revealed that the sediment mainly consists of homogenous black organic rich material. The lower part between 97 and $80 \mathrm{~cm}$ showed the highest sediment density. The water content increases gradually to the top of the core and the upper $15 \mathrm{~cm}$ of the sediment are explicitly unconsolidated and water saturated. This trend is confirmed by the X-ray image (Fig. 3.3). At the bottom of the record the X-ray image reveals two zones (around 95 and $83 \mathrm{~cm}$ depth) of disturbed sediment 
separated by the most dense part of the record $(93-87 \mathrm{~cm}$ depth). In the middle part of the core material of low density is found (Fig. 3.3). Unfortunately, no X-ray information is available from the upper $15 \mathrm{~cm}$ as they had already been subsampled in the field.

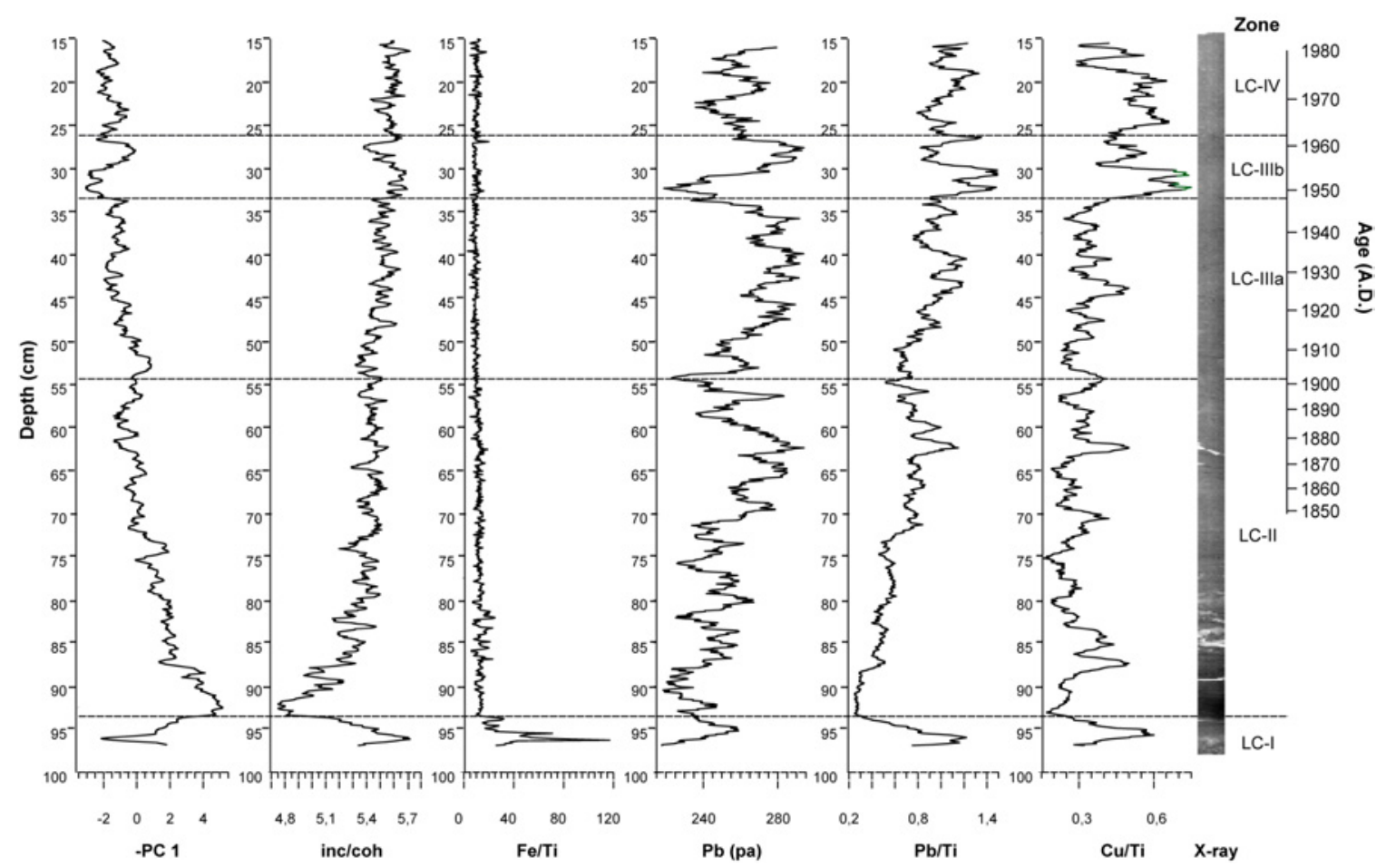

Figure 3.3. Profiles of Principle Component 1 (PC1), XRF-scanning elemental analyses and radiograph of the sediment record from Laguna Campana. Values of PC1 were multiplied by -1 in order to facilitate the comparison with the curves contributing to this PC. XRF-data are plotted as ratios and $\mathrm{Pb}$ as element peak area (pa). Data for PC1 are smoothed with a 3-point moving average, for $\mathrm{Pb}$ with a 21-point moving average and for $\mathrm{Pb} / \mathrm{Ti}$ as well as $\mathrm{Cu} / \mathrm{Ti}$ with an 11-point moving average.

\section{Chronology and age-depth modelling}

Radiocarbon dates show an age of A.D. $1880^{+75} /-180$ at $62 \mathrm{~cm}$ depth of sediment and a basal age of the sediment core at $97 \mathrm{~cm}$ of A.D. $1470^{+150 /-45}$ (Table 3.1). A further radiocarbon date at $73 \mathrm{~cm}$ depth of sediment indicates an age of A.D. $1450^{+165} /{ }_{-45}$, which is in the same range as the basal date. Both ages, at 73 and $97 \mathrm{~cm}$, show a distinct offset to the upper age in the record.

Table 3.1. List of radiocarbon dates and calibrated ages from Laguna Campana.

\begin{tabular}{llllll}
\hline Lab. - no. & $\begin{array}{l}\text { Depth } \\
(\mathrm{cm})\end{array}$ & $\begin{array}{l}\text { Sample } \\
\text { description }\end{array}$ & $\begin{array}{l}14 \mathrm{C} \text { Age } \\
\text { (B.P.) }\end{array}$ & $\begin{array}{l}\text { Median } \\
\text { cal age (A.D.) }\end{array}$ & $\begin{array}{l}2-\sigma \text { range } \\
\text { of cal age (A.D.) }\end{array}$ \\
\hline Poz-24273 & 62 & leaf & $101 \pm 27$ & 1880 & $1700-1955$ \\
Erl-13235 & 73 & leaf & $490 \pm 43$ & 1450 & $1405-1615$ \\
Erl-11389 & 97 & bulk & $456 \pm 36$ & 1470 & $1425-1620$ \\
\hline
\end{tabular}


As the formation of the lake is supposed to be associated with a landslide, which probably caused bare surfaces in the catchment area to be prone to erosion, an increased sedimentation rate as well as intense reworking seems to be plausible after soil movement. This might also have led to the inclusion of reworked organic compounds in the dating for the lowermost ages. The potential reworking is supported by PC1, which after a pronounced decrease from the bottom of the record up to $75 \mathrm{~cm}$ shows a final small increase from 75 to $72 \mathrm{~cm}$. As PC1 represents allochthonous minerogenic input it is also possible that allochthonous organic components might have been transported to the lake. Hence, these two dates yield only a terminus post quem of $\sim$ A.D. 1470 for the base of the record and were excluded from the age-depth model (Fig. 3.4.

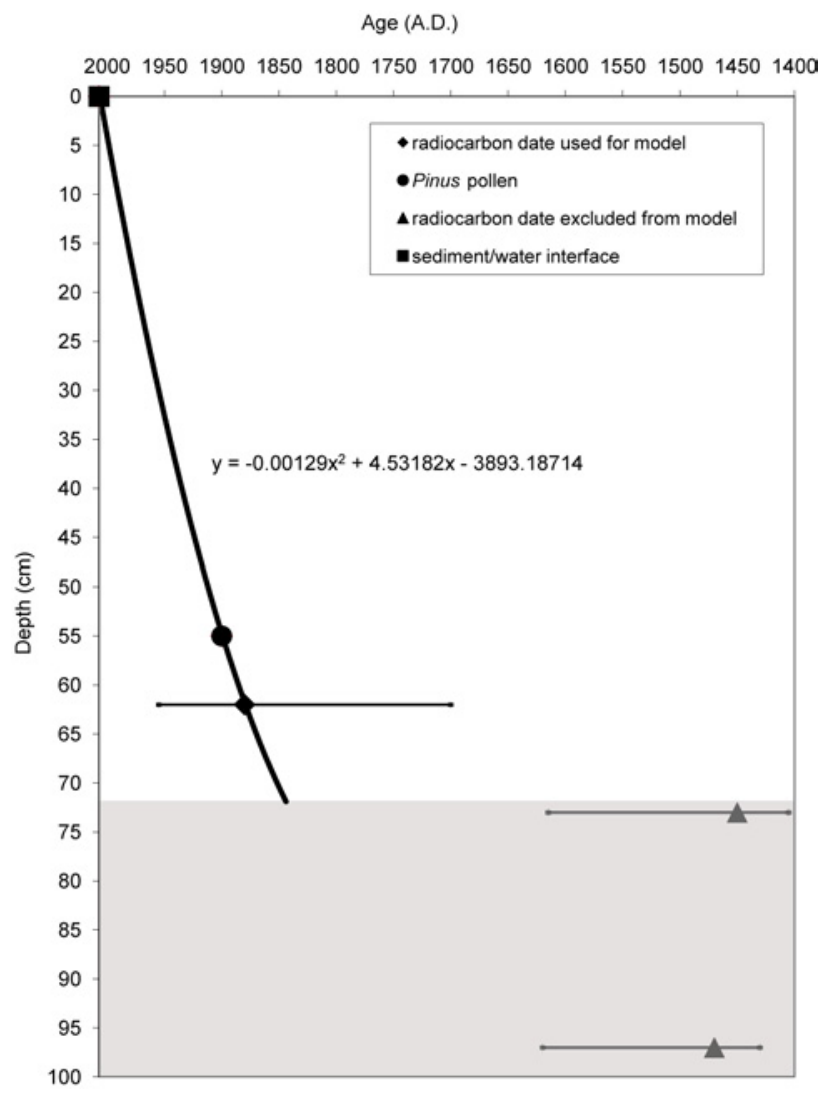

Figure 3.4. Age-depth model for the Laguna Campana lake sediment record. The shaded area represents a section potentially yielding ages that are too old, possibly related to the initial landslide forming the lake and subsequent bare soil areas in the catchment.

Therefore, only one radiocarbon age can be used and other time markers have to be included generating an appropriate agedepth model for the record above the uppermost rejected date, i.e. $72 \mathrm{~cm}$. The occurrence of Pinus pollen can be used as time marker, as this European tree species was introduced to Ecuador around the turn of the twentieth century (Neill 1999). Therefore, an extra scan of pollen slides exclusively for Pinus pollen starting at the bottom of the record was done in addition to the pollen count. The first Pinus pollen was observed at $55 \mathrm{~cm}$ (not included in 
the pollen sum and thus not displayed in the pollen diagram), which consequently indicates an age of A.D. 1900 for this sediment depth.

The age-depth model for the upper part of the record was built using the sediment/water interface as a time marker for the year of coring, i.e. 2007, the first occurrence of Pinus and the one accepted radiocarbon age at $62 \mathrm{~cm}$. Linear interpolation between the sediment/water interface and the uppermost radiocarbon date does not account for the fact that potentially the top of the uppermost part of the record might be less affected by compaction. Hence, a second order polynomial function $\left(\mathrm{y}=-0.00129 \mathrm{x}^{2}+4.53182 \mathrm{x}-3893.18714\right)$ was chosen (Fig. 3.4). The mean sedimentation rate for the upper part of the core is $4.97 \mathrm{~mm} \mathrm{a}^{-1}$ or $\sim 2 \mathrm{a} \mathrm{cm}^{-1}$.

\section{$\mathrm{XRF}$ and pollen data}

The PCA of the XRF data shows that PC1 is mainly formed by $\mathrm{K}, \mathrm{Ti}, \mathrm{Fe}, \mathrm{Rb}$, $\mathrm{Zr}$ and $\mathrm{Cu}$ (Fig. 3.2). Hence, $\mathrm{PC} 1$ is used as a reduction of these elements to one single parameter. In contrast $\mathrm{Pb}$ contributes about $88 \%$ to $\mathrm{PC} 2$. PC1 and 2 together account for $63.3 \%$ of the variations. The absence of a correlation between $\mathrm{Ti}$ as one of the major contributors to PC1 and $\mathrm{Pb}$ is not only shown by the PCA itself but also by the correlation coefficient of these two elements $\left(R^{2}=0.01\right)$. A low correlation coefficient was also found for $\mathrm{Cu}$ and $\mathrm{Ti}\left(R^{2}=0.11\right)$.

Out of 156 pollen and 48 spore types distinguished, the 35 most significant taxa are shown in a percentage diagram. Also presented are percentages of bryophytes, including Sphagnum and Phaeoceros, and the algae Botryococcus braunii (Fig. 3.5). Additionally, a summary percentage diagram illustrates 11 different groups of taxa, charcoal data as well as concentrations of pollen and Botryococcus braunii (Fig. 3.6).

Constrained cluster analysis as well as pollen and XRF data observation resulted in four main zones (LC-I to IV) and one subdivision of the third zone (LC-III a, LC-III b). These zones reflect major environmental changes in the lake and the study area. Displayed pollen taxa with $<2 \%$ representation are generally not discussed in the text.

\section{Zone LC-I (97-92 $\mathrm{cm}, 3$ pollen samples, base of the record)}

Values for PC1 are low in LC-I, being lower only in the most recent sediments of LC-IIIb and LC-IV (Fig. 3.3). However, there is a distinct rise to the top of this zone peaking at the very bottom of the next zone LC-II. The opposite can be observed for all other parameters: after a clear maximum in LC-I (representing the highest values of the whole record for the inc/coh and $\mathrm{Fe} / \mathrm{Ti}$ ratios) there is a rapid decline towards LC-II where values bottom out in the lowermost part. In general there is an opposite pattern of PC1 vs. inc/coh which can be observed in the whole record.

The zone LC-I is dominated by very high proportions of páramo taxa decreasing to the top of the zone from 83 to $45 \%$. This is mainly caused by a decrease in Poaceae pollen from 80 to $32 \%$. Cyperaceae pollen contributes to the páramo group with values between 2 and $15 \%$. The low represented subpáramo taxa (7-11\%) become more abundant to the top of the zone as shown for instance by pollen of Melastom- 


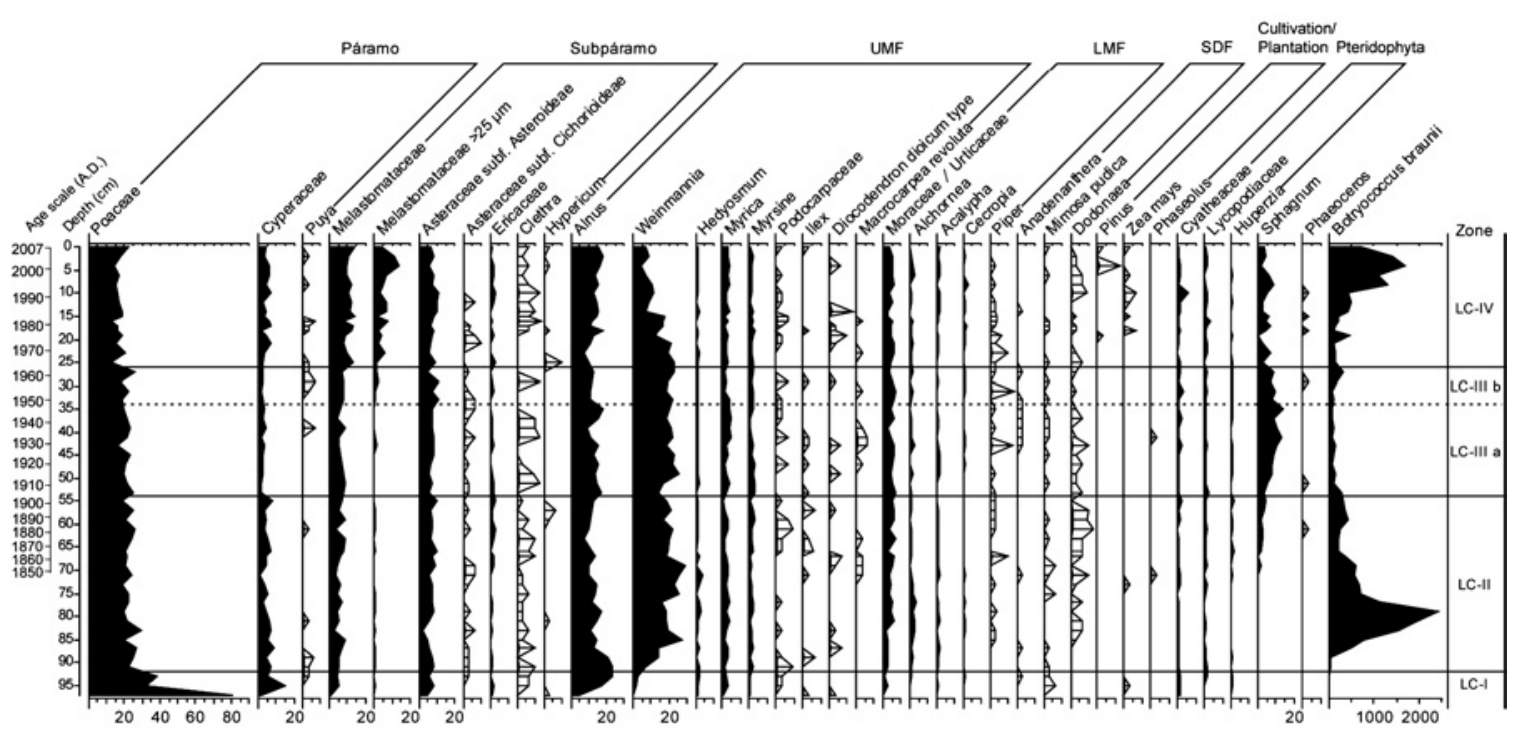

Figure 3.5. Pollen percentage diagram of Laguna Campana illustrating the most important and frequent taxa grouped into potential natural vegetation types of páramo, subpáramo, upper mountain rainforest (UMF), lower mountain rainforest (LMF) and semideciduous interandean forest (SDF) together with cultivation and plantation indicators. Taxa with $<2 \%$ representation are shown by percentage bars with an exaggeration factor of $10 \times$.

ataceae (0-6\%) and Asteraceae subf. Asteroideae (5-9\%). UMF taxa first show low pollen percentages of $7 \%$ but increase markedly within this zone to $32 \%$. This is mainly due to an initial increase of Alnus pollen from 5 to $24 \%$. Subsequently, Weinmannia pollen appears up to 3\%. Pollen of Hedyosmum (1-2\%) and Myrica (0-3\%) represents other important UMF taxa. LMF taxa show low values (0-3\%) mainly of Moraceae/Urticaceae pollen (0-2\%). One pollen grain of Zea mays (0.3\%) is present in this zone. Pteridophyta spores increase to the top of the zone from 15 to $27 \%$, to which Cyatheaceae and Lycopodiaceae spores contribute up to $2 \%$ each. Colonies of the green algae Botryococcus braunii are absent in the bottom sample but increase to the top of the zone up to $3 \%$, reaching a concentration of 8495 colonies $\mathrm{cm}^{-3}$. Charcoal particles $(1,290-3,230 \%$ relative to the pollen sum) show highest percentages and concentrations (2.3-5.3 million particles $\left.\mathrm{cm}^{-3}\right)$ in this zone. Pollen concentration increases to the top of the zone from 160,000 grains $\mathrm{cm}^{-3}$ to the highest concentration of 326,000 grains $\mathrm{cm}^{-3}$.

\section{Zone LC-II (92-54 cm, 19 pollen samples, base of the record to A.D. 1900)}

The highest values for PC1 are followed by a progressive decline towards the top of this zone (Fig. 3.3). Again, the opposite can be observed for the inc/coh ratio: starting with lowest values of the record it rises continuously. The same applies to $\mathrm{Pb}$ and the $\mathrm{Pb} / \mathrm{Ti}$ ratio respectively. From the bottom of LC-II upwards the Fe/Ti ratio shows only minor variations up to the top of the record. The $\mathrm{Cu} / \mathrm{Ti}$ ratio presents some kind of cyclical pattern but exhibits no trend (Fig. 3.3).

Decreased páramo proportions (23-39\%) stabilize in this zone, indicated mainly by 
lower pollen frequencies of Poaceae (19-27\%) and Cyperaceae (3-8\%). Subpáramo taxa remain stable (4-10\%), primarily due to pollen percentages of Melastomataceae (3-9\%), Asteraceae subf. Asteroideae (2-10\%) and Ericaceae (0-3\%). UMF taxa are well represented, but decrease in the upper part of the zone from 46 to $33 \%$. This is mainly caused by a marked increase of Weinmannia pollen from 7 to $29 \%$ at the beginning of this zone and a subsequent decrease to $19 \%$ in the upper part of the zone. Alnus pollen shows a decreasing trend from $24 \%$ to a minimum of $8 \%$. Pollen percentages of Hedyosmum (0-4\%), Myrica (1-4\%) and Myrsine (1-3\%) are stable but lower. LMF taxa are still poorly represented but reach the highest proportion of $13 \%$, mainly through increasing values of Moraceae/Urticaceae pollen from 2 to $7 \%$ as well as higher pollen percentages of Alchornea (0-3\%) and Acalypha (0-2\%). Pteridophyta spores increase slightly to the top of the zone from 15 to $17 \%$, mainly through increasing unknown types (not shown in the diagram). The most frequent known spore types such as Cyatheaceae, Lycopodiaceae and Huperzia (0-2\%) remain stable. Sphagnum spores appear and increase to the end of this zone up to 5\%. After a distinct increase in the first half of the zone Botryococcus braunii colonies show the highest proportion of $2,452 \%$ at a depth of $81 \mathrm{~cm}$ and decrease subsequently to $294 \%$. This is mirrored by the concentration data of Botryococcus braunii starting at 20,000 colonies $\mathrm{cm}^{-3}$ at the base of this zone, peaking at 5.5 million colonies $\mathrm{cm}^{-3}$ at $81 \mathrm{~cm}$ depth and decreasing subsequently to 400,000 colonies $\mathrm{cm}^{-3}$. Varying charcoal percentages (802-2242\%) and concentrations (1.0-4.2 million particles $\mathrm{cm}^{-3}$ ) show a decreasing trend but the last sample in this zone yields a high value of 2.6 million particles $\mathrm{cm}^{-3}$ which is twice as much as the previous sample. Pollen concentrations decrease slightly to the top of this interval from 283,000 grains $\mathrm{cm}^{-3}$ to 87,000 grains $\mathrm{cm}^{-3}$ parallel to charcoal concentrations. The highest pollen concentration occurs at the same depth as the concentration of Botryococcus braunii colonies peaks.

Zone LC-IIIa (54-34 cm, 10 pollen samples, A.D. 1900-1950)

The trends in element composition described for LC-II continue in LC-IIIa. However, magnitudes are much lower.

Páramo taxa show lower values between 29 and 20\% than in zone LC-II, which is primarily due to lower proportions (2-5\%) of Cyperaceae pollen. Compared to the top of the previous zone UMF taxa are represented by slightly higher proportions between 38 and 49\%, mainly because of higher pollen percentages of Weinmannia (14-26\%) and Alnus (10-18\%). A first pollen grain of Phaseolus is found in this zone. Sphagnum spores markedly increase to the highest percentage of $14 \%$ at the top of the zone, while colonies of Botryococcus braunii continue to decrease markedly reaching very low percentages of $60 \%$ and concentrations of 74,000 colonies $\mathrm{cm}^{-3}$. Charcoal particles $(783-1,581 \%)$ are less frequent than in the previous zone and show stable but low concentrations with a maximum of 1.4 million particles $\mathrm{cm}^{-3}$. The slightly decreasing trend in pollen concentration as observed in the previous zone continues, reaching minimum values of 83,000 grains $\mathrm{cm}^{-3}$. 


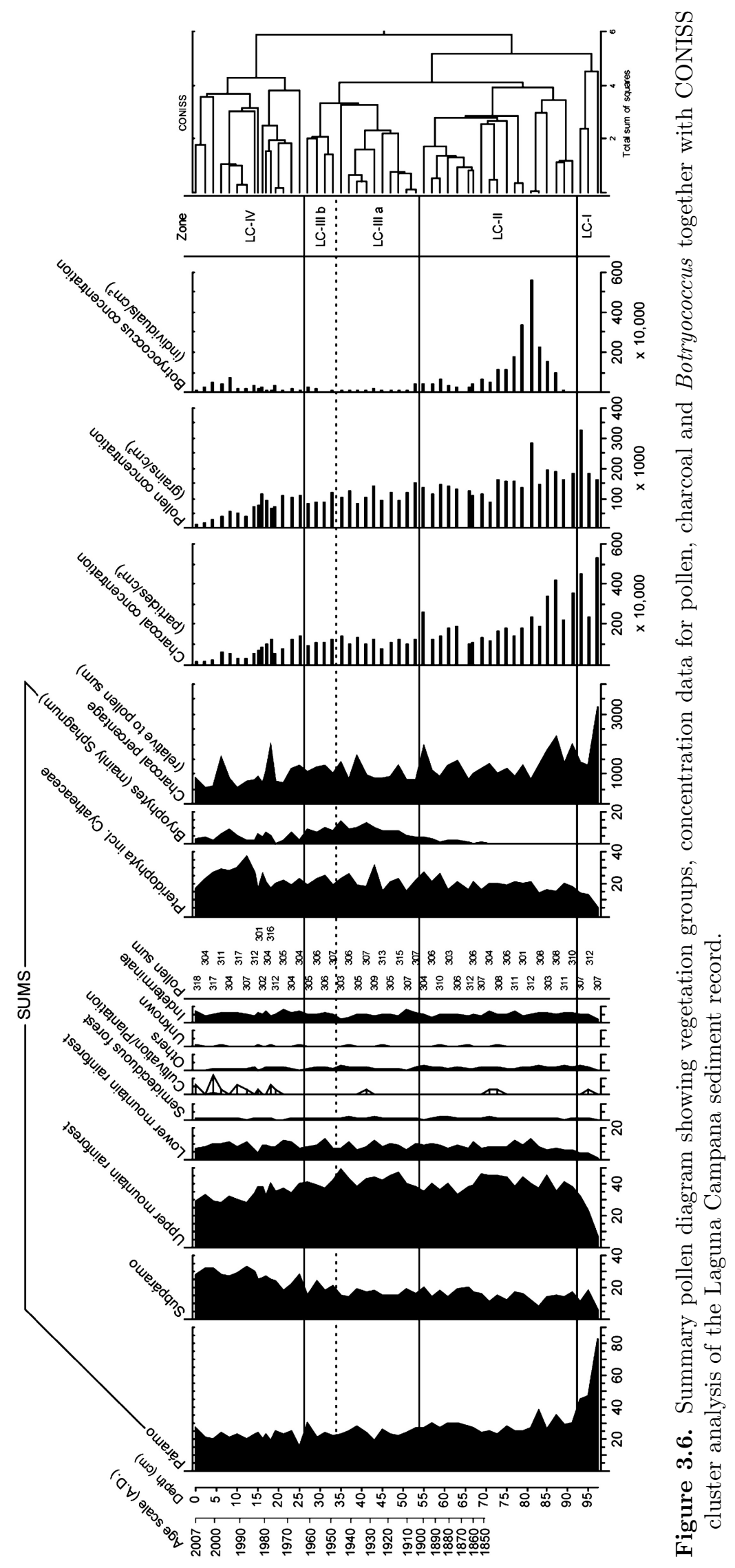


Zone LC-IIIb (34-26 cm, 4 pollen samples, A.D. 1950-1960)

Apart from those in LC-I, variations in all parameters related to element composition are highest in LC-IIIb. The lowest values in $\mathrm{PC} 1$ and $\mathrm{Pb}$ are followed by values in the range of the upper part of LC-IIIa. In contrast the highest values of the record in the inc/coh, $\mathrm{Pb} / \mathrm{Ti}$ and $\mathrm{Cu} / \mathrm{Ti}$ ratios are followed by much lower values.

In this subzone pollen data are comparable to the previous zone (LC-IIIa). However, UMF taxa decrease from 41 to $36 \%$, most notably due to lower values of Alnus (11-12\%) and Myrica (1-4\%) pollen. Sphagnum spores show slightly lower values between 7 and $10 \%$ than at the top of the previous subzone. Botryococcus braunii colonies show an opposite trend of slightly increasing values to the top of LC-IIIb reaching values of $314 \%$ and concentrations of 260,000 colonies $\mathrm{cm}^{-3}$.

\section{Zone LC-IV (26-0 cm, 16 pollen samples, A.D. 1960-present)}

LC-IV shows only small variations in $\mathrm{PC} 1$ and the inc/coh ratio. $\mathrm{Pb}, \mathrm{Pb} / \mathrm{Ti}$ and $\mathrm{Cu} / \mathrm{Ti}$ show some changes at high levels. In this interval greater changes in the pollen composition are observed than in zones LC-IIIa/b. Páramo taxa remain stable between 15 and 27\%, but Cyperaceae pollen shows higher proportions (2-7\%). Subpáramo taxa increase towards the top reaching highest values of $24 \%$. This is mainly due to higher pollen percentages of Melastomataceae (8-15\%) exceeding those of all prior zones. In particular the pollen type of Melastomataceae $>25 \mu \mathrm{m}$ appears for the first time with considerably high percentages and increases markedly to reach a highest proportion of $14 \%$ at the top of this zone. A distinct decrease of UMF taxa towards the top from 40 to $28 \%$ is primarily due to the marked decline of Weinmannia pollen from 23 to $4 \%$. In contrast Alnus pollen increases slightly from $8 \%$ to $18 \%$. LMF taxa (4-11\%) and its components such as Moraceae/Urticaceae pollen (3$6 \%$ ) are stable above zone LC-II. Pinus (0-1\%) and Zea mays (0-1\%) pollen is more frequent. Pteridophyta spores, mainly unknown types, show higher proportions in the second half of this zone than in all previous zones and reach maximum values of 38\%. Spores of Cyatheaceae (0-7\%) and Lycopodiaceae (0-3\%) do not show notable changes. Sphagnum spores (0-9\%) fluctuate inversely to Botryococcus braunii colonies. However, Sphagnum is less important in this zone than in the previous one, while Botryococcus braunii colony percentages increase markedly from 85 to 1,696\% to the top. However only slightly higher Botryococcus braunii concentrations of a maximum of 520,000 colonies $\mathrm{cm}^{-3}$ are observed compared to the previous zone. Charcoal particles show high variable percentages (543-1,914\%) but concentrations clearly decrease to the top of the zone to the minimum of 108,000 particles $\mathrm{cm}^{-3}$. The same decreasing trend is observed for pollen concentrations reaching their minimum of 13,000 grains $\mathrm{cm}^{-3}$ in the uppermost sample. 


\subsection{Interpretation and discussion}

\section{Lake genesis and subsequent vegetation development}

Geomorphologic observations suggest that the lake was formed by a shallow landslide forming a dam towards the downhill side of the lake. Due to the high relief energy, with steep slopes resulting in geomorphologic instability, shallow landslides are common in the tropical mountain forest area of the Ecuadorian Andes (Schrumpf et al. 2001; Bussmann et al. 2008; Gradstein et al. 2008). Many gaps without vegetation or with early succession stages of vegetation also indicate erosion and mass movements surrounding the study area (Wilcke et al. 2003).

The fact that it was impossible to penetrate any further into the sediment suggests that the whole sedimentary sequence of Laguna Campana was recovered. A clear separation of a zone of low minerogenic input together with high organics instead of a more mixed signal might indicate that only the uppermost part of the soil horizons were displaced, which become rich in humus towards higher elevations (Gradstein et al. 2008). Removal of the organic layer and the uppermost part of the A-horizons in the head area and redeposition of the material in the foot area is typical of the shallow landslides described in the study area (Bussmann et al. 2008). The highest charcoal percentages and concentrations found in the bottom sample indicate that fires may have played a significant role in soil erosion and furthermore may have triggered the landslide causing lake formation.

$\mathrm{Fe} / \mathrm{Ti}$ ratios are much lower in the upper part of the record. Therefore, Fe migration within the sediment column appears to be rather unlikely. Hence, we speculate that the iron enrichment in LC-I is a relict of former soil formation processes. Most studies dealing with vertical distribution of metals in soil profiles report a tendency toward concentration in the upper horizons. The surface enrichment of metals in soils may be a result of chemical complexing by organic compounds (Mirsal 2008). Low pH might have caused an upward migration of Fe as acidic and reducing conditions are the most favourable for metal solubilisation (Chuan et al. 1996; Charlatchka and Cambier 2000). Reductive dissolution of clay-sized Fe(III) hydroxides and vertical and lateral leaching of the released Fe was also suggested in an altitudinal transect close to the study area (Wilcke et al. 2008). The same mechanisms might influence $\mathrm{Pb} / \mathrm{Ti}$ and $\mathrm{Cu} / \mathrm{Ti}$ ratios. For example for $\mathrm{Cu}$ fixation mainly organic substances as well as pedogenic Feand Mn-oxides are important, as are pedogenic oxides, notably for $\mathrm{Pb}$ enrichment (Hiller and Brümmer 1991; Chuan et al. 1996; Charlatchka and Cambier 2000). As most heavy minerals form complexes with humic acids they are preferentially enriched in the top humus layer or topsoil (Brümmer et al. 1986). Additionally, an enrichment of $\mathrm{Pb}$ and $\mathrm{Cu}$ in topsoil might be caused by fallout from atmospheric sources before the landslide. Unfortunately, no soil investigations have been carried out in our study to verify this hypothesis of $\mathrm{Fe}, \mathrm{Pb}$ and $\mathrm{Cu}$ enrichment in topsoil. Although soil development might vary considerably between the warm and humid eastern side of the Cordillera Real (Beck et al. 2008b), investigations on the western part showed reddish subsurface horizons indicating redoximorphic processes (Beck et al. 2008b) or an enrichment of Fe at least in the A-horizon (Schrumpf et 
al. 2001). Therefore, if this scenario is valid for the study site it provides a hint that the bottom of the record is formed by the upper part of a displaced soil and that the whole sediment sequence was recovered. If there had been a number of slumps rather than just one, the data suggests that at least the last event was recovered completely.

According to the two lowermost radiocarbon dates which probably represent the formation of Laguna Campana the respective landslide has a terminus post quem of $\sim$ A.D. 1470. This indicates that landslides already occurred during this time. As the landslide removed the vegetation cover from a large part of the catchment of Laguna Campana, this probably led to further erosion which is mirrored by minerogenic input. Increased post-landslide erosion on sparsely vegetated landslide areas was also previously observed by Bussmann et al. (2008). After vegetation recovery erosion and hence minerogenic input decreases in LC-II (Fig. 3.3).

Further evidence for a complete recovery of the sediment sequence deposited in Laguna Campana comes from pollen analysis representing mainly local vegetation changes. The bottom sample showed very high percentages (up to 80\%) of Poaceae, indicating that the vegetation at the disturbed area most likely consisted of high Poaceae proportions before the landslide occurred. As the surroundings after the landslide probably still held vegetation rich in grasses, these could quickly become established in the area. It seems that during this first successional stage other vegetation components were initially suppressed by the dense grass layer. This is supported by studies of Bussmann et al. (2008), showing that on landslides grasses build a dense layer and limit the establishment of bush species. The high Poaceae presence of $\sim 20 \%$ persisting after the initial peak represents a remaining above-average grass proportion in the study area, as such high grass abundances normally occur in much higher elevations where páramo is found (Weng et al. 2004a).

After this first establishment of grasses, vegetation succession began, even though a high proportion of grass remained. Cyperaceae grew up in wet locations such as small ground depressions and watersides. At the same time pioneer trees of Alnus, here Alnus acuminata, expanded on moist and probably disturbed sites (Weng et al. $2004 \mathrm{~b}$ ) and their pollen reached its highest proportion of $24 \%$ in an early successional stage. Some Alnus pollen could have originated at lower elevations and might have been dispersed to higher altitudes, but as pollen proportions never fell below $5 \%$ it probably reflects local occurrence (Weng et al. 2004a). Ongoing vegetation regeneration led to an expansion of Weinmannia up to $\sim 30 \%$ in the beginning of zone LC-II, while Alnus declined over the same interval. As different species of Weinmannia have a large altitudinal range in the study region of the Podocarpus National Park (Lozano et al. 2003; Homeier and Werner 2008), Weinmannia pollen could have been transported by wind. However, most species occur in the UMF and subpáramo zone (Niemann et al. 2009) and studies carried out in New Zealand (Moar 1970) revealed that high pollen frequencies of Weinmannia certainly imply local dominance. Based on that, the high pollen presentation of Weinmannia probably indicates that this genus contributing to the upper mountain rainforest recovered in the area to a certain extent, possibly due to decreasing human disturbances. Mainly Hedyosmum, Myrica and Myrsine were associated with dominating trees of Weinmannia. Together with Melastomataceae and Asteraceae this vegetation composition constituted a con- 
siderable part of the local vegetation. Woody plants probably represented small trees and shrubs in the understory. Myrica and Myrsine also are pioneer species, indicative of disturbance. A high occurrence of pteridophyta was established rapidly during the successional stages of Alnus and Weinmannia and increased throughout the whole record from 6 up to $38 \%$. This gives an indication of vegetation structure, as ferns may be characteristic of a wet understory but also show high occurrences on open soils after disturbance (Bussmann et al. 2008). Hence, pteridophyta at Laguna Campana indicate most likely sparse vegetation on open soils or subsequently open secondary forests stands. This converted vegetation composition probably harbors much less biodiversity than undisturbed natural UMF occurring elsewhere.

\section{Anthropogenic impact and further vegetation changes}

A crucial factor for the vegetation development at Laguna Campana is human influence. Already the bottom sample showed the highest charcoal percentage of 3,230\% relative to the pollen sum and the highest charcoal concentration of 5.3 million particles $\mathrm{cm}^{-3}$, indicating high fire frequency. Former studies in the Podocarpus National Park region concluded that increasing fire frequencies during Holocene times were most likely of anthropogenic origin. Common fires during late Holocene times concurrent with high grass pollen occurrence have been previously interpreted as indication of early human activities (Niemann and Behling 2008a; Niemann et al. 2009).

Given the fact that fires were used for slash and burn purposes (Niemann and Behling 2008a) a natural cause for fire is probably negligible. During the whole duration of the record fires occurred and affected the vegetation. These might have been more intense in this area, compared to more easterly located sites in the PNP, due to drier climatic conditions. The lower charcoal concentration in the uppermost zone (LC-IV) probably does not reflect decreasing fire frequency. Charcoal percentages similar to those in previous zones suggest rather constant fire occurrences. The high water content and lower sediment compaction in the top samples may be responsible for the lower concentration data calculated per sampled volume. This applies to charcoal as well as pollen concentrations. The initial high proportions of Poaceae after the landslide may also indicate human impact. As Bussmann et al. (2008) described, a first succession of a dense grass layer occurs particularly on anthropogenically caused landslides and differs from that on natural ones. Human land use had already opened up the vegetation cover before the landslide event and probably reduced the local biodiversity. This could have favored Poaceae distribution at elevations up to 2,500 $\mathrm{m}$ a.s.l., where naturally UMF dominates.

A marked decrease of Weinmannia during very recent times also indicates human activities. High fire frequencies strongly reduce the occurrence of Weinmannia (Niemann and Behling 2009). As burning for forest clearance or new farming areas is still a common method used by settlers and has been so for centuries (Beck et al. 2008c), Weinmannia may have been seriously affected by these fires during the last decades. This supports the assumption that fires remained frequent in the zone LC-IV. Additionally, Weinmannia might have been the target of timber extraction. Concurrently with the decline in Weinmannia during most recent times, Melastomataceae has in- 
creased markedly. While the pollen type including all Melastomataceae $<25 \mu$ m only expanded slightly (8-15\%) in the uppermost zone, the pollen type $>25 \mu \mathrm{m}$ occurred for the first time in high abundances. The high pollen input from Melastomataceae $>25 \mu \mathrm{m}$ probably originated from a local stand of Melastomataceae at the shore of Laguna Campana observed during field work.

Furthermore, the crop plant Zea mays and the domesticated wild bean Phaseolus, already present in zone LC-I, evidence permanent land use in the area. Ancient human settlements have taken place in the area since $\sim 4000$ years cal B.P. (Guffroy 2004). The Inca occupied the area of Loja and Zamora in the middle of the fifteenth century. During their 70-year rule in southern Ecuador (A.D. 1463-1531) the indigenous group of the Saraguros was brought to the Ecuadorian highlands. Their traditional mixed cultivation system featured maize, beans, potatoes and other tubers. As early as the nineteenth century cattle breeding supplemented their livelihood (Pohle 2008). However, lower abundances of cultivation indicators found throughout the zones LC-I to LC-III suggest a phase of less human activity compared with that in most recent times. This is supported by another nearby palynological study, in which the time period between the seventeenth and twentieth centuries was identified as a phase of lower human activity (Niemann and Behling 2008a). Thus in particular, the more frequent Zea mays pollen found in zone LC-IV suggests expanded cultivation during the last decades. This may be related to mestizo settlements in the study area founded during the acceleration of the Latin American Industrialization in the mid twentieth century (Niemann and Behling 2008a; Pohle 2008). Nowadays agriculture is still the most important economic activity in southern Ecuador. In the Loja province $44 \%$ of the economically active population works in agriculture (INEC 2001). Population pressure and improved infrastructure have opened even ecologically unsuitable areas to agricultural colonization during the past 50 years (Pohle 2008). The low amount of canopy trees like Clethra and Podocarpus found in the pollen diagram probably results from the fact that they were already objectives for wood extraction in the mid sixteenth century after the Spanish conquest (Guffroy 2004), mainly for the construction of the city of Loja.

Pinus pollen found in the record gives evidence of European influence in the study area. Pines were introduced only after colonization of the southern hemisphere by Europeans (Richardson 2000) at the beginning of the 20th century. Today large stands of introduced Pinus can be found in some areas of the Inter-Andean valleys (Neill 1999). Pinus pollen found more frequently in the uppermost zone LC-IV confirms the expansion of plantations during the last decades.

Although the present vegetation near Laguna Campana is composed of a considerable proportion of Puya, pollen of Puya is poorly represented in the pollen diagram because of its rare flowering. However, Puya pollen was found in samples from the lower zones as well as in the most recent samples. Apparently, Puya was already part of the vegetation around Laguna Campana in former times and persisted till today. Puya observed in the field seems to be fire resistant, which probably favored long term existence in this area.

A different kind of human impact seems to be reflected by heavy metals. The increase in $\mathrm{Pb} / \mathrm{Ti}$ ratio from the bottom to the top of the record indicates enrichment 
in $\mathrm{Pb}$ relative to $\mathrm{Ti}$. As $\mathrm{Ti}$, which is represented by $\mathrm{PC} 1$ in Fig. 3.3 decreases continuously, the increase in the ratio might also be caused by a constant supply of $\mathrm{Pb}$ which is independent of the supply of lithogenic input. However, absolute counts for $\mathrm{Pb}$ also show an increasing trend over the record. Chemical diagenesis seems to be of minor importance as above the peak in LC-I the Fe/Ti ratio varies only little. If $\mathrm{Pb}$ had migrated upwards in the profile, variations would have been observed in the $\mathrm{Fe} / \mathrm{Ti}$ ratio as $\mathrm{Pb}$ is less mobile than Fe (Charlatchka and Cambier 2000; Dorronsoro et al. 2002). There is also a growing body of information for ombotrophic peat bogs suggesting that $\mathrm{Pb}$ is immobile in this environment (Shotyk et al. 2005). The continuous rising trend of $\mathrm{Pb}$ from the bottom to the top of the record impedes the calculation of an enrichment factor because no natural background deposition of $\mathrm{Pb}$ was recovered in the record. As the XRF Scanner provides only semi-quantitative data, it is neither possible to obtain absolute inputs nor distinguish between lithogenic and anthropogenic components in the same way as has been done in previous work (Shotyk et al. 2001, 2005; Koinig et al. 2003). Nevertheless, the rise in $\mathrm{Pb}$ and $\mathrm{Pb} / \mathrm{Ti}$ respectively suggests an enrichment of $\mathrm{Pb}$ independent of lithogenic supply from the beginning of the record. Since chemical diagenesis does not seem to have been the driver we suggest an increased atmospheric supply in this case as the atmospheric loading is especially important for lead. It is estimated that over $95 \%$ of the lead is of anthropogenic origin (Salomons and Förstner 1984). Similar observations have been made in lakes and peat profiles in Europe (e.g. Hettwer et al. 2003; Koinig et al. 2003; Shotyk et al. 2005; Guyard et al. 2007) and other South American countries like Peru or Bolivia (Abbott and Wolfe 2003; Cooke et al. 2007, 2008).

Distinct $\mathrm{Pb}$ anomalies were attributed to long range transport of atmospheric $\mathrm{Pb}$ contamination from $\mathrm{Pb}$ mining and smelting during Roman times in Europe (Hettwer et al. 2003; Shotyk et al. 2005; Guyard et al. 2007). The same studies show an even more distinct $\mathrm{Pb}$ peak related to the introduction of aerosols from leaded gasoline combustion or coal burning (Koinig et al. 2003; Shotyk et al. 2005). In Bolivia and Peru atmospherically derived input is also associated with smelting processes. Following the Inca conquest of the Andes $\sim$ A.D. 1450, marked increases in $\mathrm{Pb}$ are noted at all study sites and after the Hispanic conquest, large increases in $\mathrm{Pb}$ pollution are noted, only to be superseded by industrial development (Cooke et al. 2007, 2008). The source of the lead in the study area remains to be identified, but combustion can be assumed at least during subrecent times. Surprisingly, there is no contemporaneous rise in $\mathrm{Cu}$ from LC-I to LC-IIIa. Although there are variations, it remains in the same range. Only in LC-IIIb ( $\sim \mathrm{A}$.D. 1950) is there a distinct rise in $\mathrm{Cu} / \mathrm{Ti}$ which is contemporaneous with the highest values in $\mathrm{Pb} / \mathrm{Ti}$ but also the lowest values in $\mathrm{PC} 1$ and $\mathrm{Pb}$. This either indicates a further increase in the atmospheric supply of heavy metals or a greater dependence of the ratio signal on lithogenic input. Elevated $\mathrm{Cu}$ and $\mathrm{Pb}$ contamination was found close to small scale gold mining areas in southern Ecuador, such as in the Nambija region approximately $20 \mathrm{~km}$ east of the study site. The main gold rush started there during the 1980s but due to different extraction methods primarily waterways have been affected by the main contaminants which consist of $\mathrm{Cu}, \mathrm{Pb}$ and $\mathrm{Cd}$ (Swedish Environmental Systems 1999; Tarras-Wahlberg et al. 2000). 


\section{Hydrological variations}

Minerogenic input (PC1) is probably related to lake level variations as higher precipitation causing higher lake levels will also cause an increase in erosion (Haberzettl et al. 2007). The green algae Botryococcus braunii is known to thrive in freshwater bogs, temporary pools, ponds and lakes (Batten and Grenfell 1996). In other studies Botryococcus has already been used as indicator of open water conjoined with other indications (Davis 1999; Niemann and Behling 2009). Higher Botryococcus presence is mostly coupled with increases in PC1 values in the record (Fig. 3.7). Accordingly, both are interpreted as occurring concurrently with increased moisture availability. In some cases increased PC1 values are observed without an increase in Botryococcus. This is probably caused by single erosion events which did not have a longer lasting impact on the lake level. Interpretation is implemented by the occurrences of Sphagnum as an additional indicator, meaning a higher presence of Sphagnum for periods with lower water level and hence variations in precipitation.

Botryococcus was absent in the bottom sample and started to increase markedly to its highest percentages and concentrations in the lower part of zone LC-II, indicating that the Laguna Campana water level rose quickly after the landslide event. Despite an increasing input of organic material Sphagnum was virtually absent in this period. Therefore the water level must have been high.

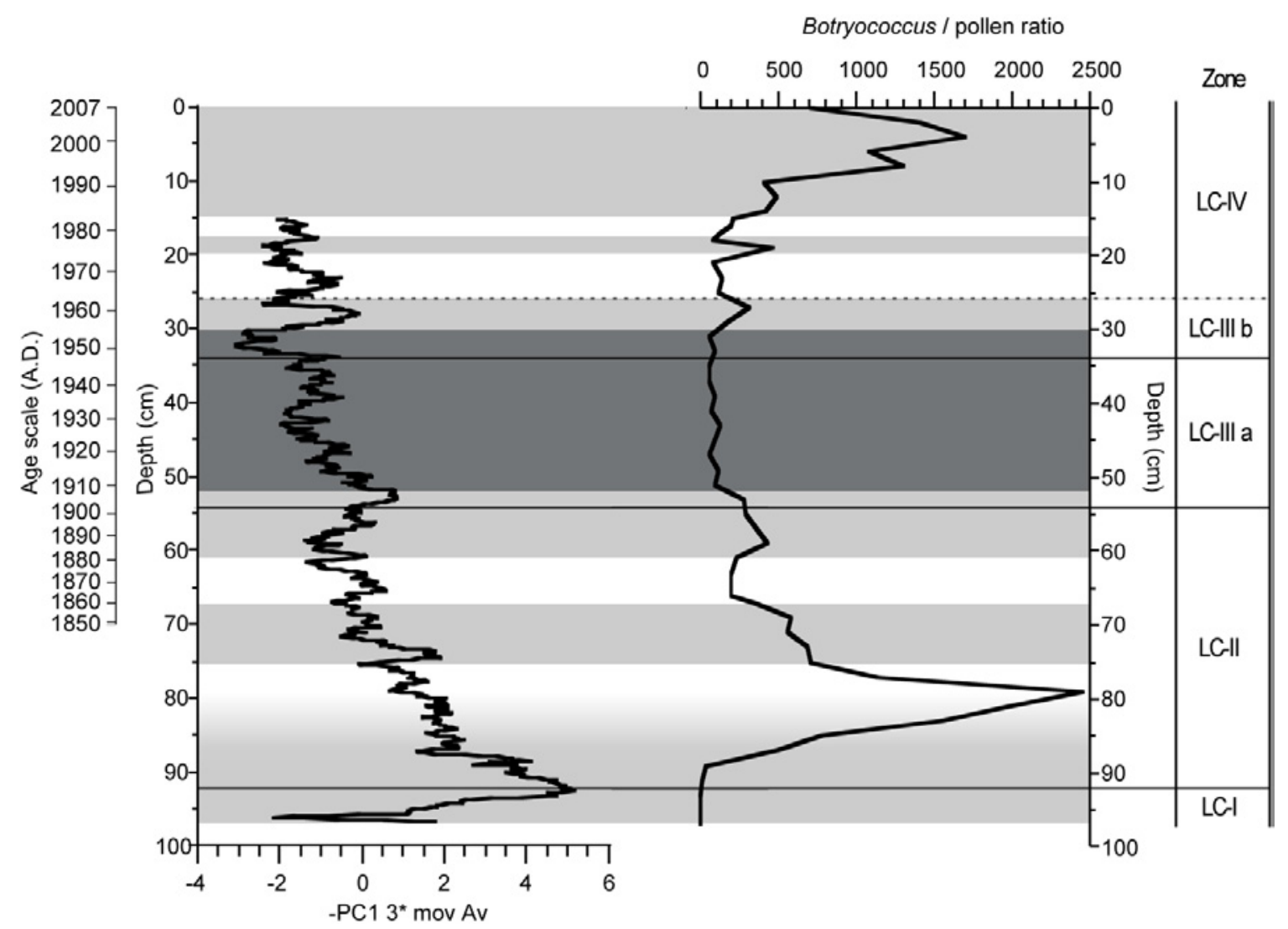

Figure 3.7. Comparison of Principle Component 1 (-PC1, 3-point moving average) representing minerogenic input and Botryococcus colonies related to the total pollen sum. 
The landslide also was probably triggered by very moist conditions, which indicates that the lower part of the record is the wettest. Unfortunately, during the highest occurrence of Botryococcus in LC-II the PC1 signal is overprinted by the vegetation development in the catchment area. Hence, the high but decreasing PC1 values in this depth are probably a response to the developing vegetation cover and only marginally caused by hydrological variations.

After a steep decrease Botryococcus stabilizes. Together with the first re-increase in $\mathrm{PC}$, this points to still wet conditions. However, with the beginning of Sphagnum development a change to somewhat drier conditions is suggested. The trend of drier conditions continued over the zones LC-IIIa/b, related to the time period of $\sim$ A.D. 1900-1960. The driest conditions then occurred during the transition between zone LC-IIIa and b around A.D. 1950, when Botryococcus showed its sparsest presence, Sphagnum reached its highest proportions and PC1 yielded its lowest values. At this time the peat moss Sphagnum started to expand and peat bogs arose in the littoral areas.

A marked increase in PC1 values from zone LC-IIIb ( A.D. 1960) onwards reflects a return to more humid conditions probably because of higher precipitation during the last $\sim 50$ years. During the most recent period Botryococcus expanded and Sphagnum was suppressed because of a lake level rise. Although the Botryococcus concentration did not increase markedly in LC-IV, which is probably related to the low sediment compaction, the Botryococcus to pollen ratio gives information about a relative but distinct rise. Additionally, the highest proportions of pteridophyta during this time, including a considerable presence of tree ferns of the genus Cyatheaceae (0-7\%), support wetter climates.

\subsection{Conclusions}

The multi-proxy approach provided an ample environmental reconstruction combining multiple indicators of human impact and past processes inducing lake genesis and vegetation development. Laguna Campana originated from a shallow landslide which displaced only the uppermost soil horizons. The terminus post quem for the occurrence of the landslide which might have been promoted by anthropogenic impact is A.D. 1470. Humans influenced the study area and its vegetation continuously by slash and burn practices, pastures and deforestation at least for the recorded time period and especially during most recent times. Therefore, a dense mountain rainforest could not recuperate in the area. This means that a vegetation structure with diminished biodiversity compared to natural conditions might be similar to the present appearance since the formation of Laguna Campana. An anthropogenic impact can also be concluded from the continuous rise of lead, which can hardly be explained by natural input. Reconstructed hydrological variations probably caused by variations in precipitation affected riparian vegetation but had no major influence on the vegetation at a greater distance from the lake. However, the wettest conditions probably triggered the landslide and the driest conditions during A.D. 1900-1960 induced local peat bog development in the littoral. 


\subsection{Acknowledgements}

We wish to sincerely thank Antoine Cleef, Urs Neumeier, Hans Ruppert and Guillaume St-Onge for fruitful discussions. We also acknowledge Fernando Rodríguez and Isabelle Matthias for support during field work. We would like to thank the associate editor Eric C. Grimm and two anonymous reviewers for their comments which improved an earlier version of the manuscript. Torsten Haberzettl was supported by a postdoctoral fellowship scholarship provided by Le Fonds Québécois de la Recherche sur la Nature et les Technologies (FQRNT). The Deutsche Forschungsgemeinschaft (DFG) is thanked for financial support within the research group FOR 816 (Be 2116/8-1). Logistic support was kindly provided by the staff of FOR 816.

\subsection{References}

Abbott MB, Wolfe AP (2003) Intensive pre-incan metallurgy recorded by lake sediments from the Bolivian Andes. Science 301:1893-1895

Aguirre Z, Cabrera O, Sanchez A, Merino B, Maza B (2003) Composición floristica, endemismo y etnonotanica de la vegetación del Sector Oriental, parte baja del Parque Nacional Podocarpus. Lyonia 3:5-14

Baldock JW (1982) Geology of Ecuador-explanatory bulletin of the national geological map of the Republic of Ecuador. Ministerio de Recursos Naturales y Energéticos, Dirección General de Geología y Minas, Quito

Barthlott W, Mutke J, Rafiqpoor D, Kier G, Kreft H (2005) Global centers of vascular plant diversity. Nova Acta Leopold 92:61-83

Batten DJ, Grenfell HR (1996) Botryococcus. In: Jansonius J, MacGregor DC (eds) Palynology: principles and applications. Am Assoc Stratigr Palynol Found, vol 1, Dallas, pp 205-214

Beck E, Bendix J, Kottke I, Makeschin F, Mosandl R (eds) (2008a) Gradients in a tropical mountain ecosystem of Ecuador. Ecol Stud 198. Springer, Berlin, Heidelberg

Beck E, Makeschin F, Haubrich F, Richter M, Bendix J, Valerezo C (2008b) The ecosystem (Reserva Biológica San Francisco). In: Beck E, Bendix J, Kottke I, Makeschin F, Mosandl R (eds) Gradients in a tropical mountain ecosystem of Ecuador. Ecol Stud 198. Springer, Berlin, Heidelberg, pp 1-13

Beck E, Harting K, Roos K (2008c) Forest clearing by slash and burn. In: Beck E, Bendix J, Kottke I, Makeschin F, Mosandl R (eds) Gradients in a tropical mountain ecosystem of Ecuador. Ecol Stud 198. Springer, Berlin, Heidelberg, pp 371-374 
Behling H (1993) Untersuchungen zur spätpleistozänen und holozänen Vegetationsund Klimageschichte der tropischen Küstenwälder und der Araukarienwälder in Santa Catarina (Südbrasilien). Diss Bot 206, Cramer, Berlin/Stuttgart

Bendix J, Rollenbeck R, Richter M, Fabian P, Emck P (2008a) Climate. In: Beck E, Bendix J, Kottke I, Makeschin F, Mosandl R (eds) Gradients in a tropical mountain ecosystem of Ecuador. Ecol Stud 198. Springer, Berlin, Heidelberg, pp 63-73

Bendix J, Rollenbeck R, Richter M, Fabian P, Emck P, Richter M, Beck E (2008b) Climate variability. In: Beck E, Bendix J, Kottke I, Makeschin F, Mosandl R (eds) Gradients in a tropical mountain ecosystem of Ecuador. Ecol Stud 198. Springer, Berlin, Heidelberg, pp 281-290

Brümmer GW, Gerth J, Herms U (1986) Heavy metal species, mobility and availability in soils. Z Pflanzenernähr Bodenk 149:382-398

Brunschön C, Behling H (2009) Late quaternary vegetation, fire and climate history reconstructed from two cores at Cerro Toledo, Podocarpus National Park, southeastern Ecuadorian Andes. Quat Res 72:388-399

Bush MB, Hanselman JA, Hooghiemstra H (2007) Andean montane forests and climate change. In: Bush MB, Flenley JR (eds) Tropical rainforest responses to climatic change. Springer, Praxis, pp 33-54

Bussmann RW (2001) The montane forests of Reserva Biológica San Francisco (ZamoraChinchipe, Ecuador)-vegetation zonation and natural vegetation. Die Erde $132: 9-25$

Bussmann RW, Wilcke W, Richter M (2008) Landslides as important disturbance regimes-causes and regeneration. In: Beck E, Bendix J, Kottke I, Makeschin F, Mosandl R (eds) Gradients in a tropical mountain ecosystem of Ecuador. Ecol Stud 198. Springer, Berlin, Heidelberg, pp 319-330

Charlatchka R, Cambier P (2000) Influence of reducing conditions on solubility of trace metals in contaminated soils. Water Air Soil Pollut 118:143-168

Chuan MC, Shu GY, Liu JC (1996) Solubility of heavy metals in a contaminated soil: effects of redox potential and pH. Water Air Soil Pollut 90:543-556

Cooke CA, Abbott MB, Wolfe AP, Kittleson JL (2007) A millennium of metallurgy recorded by lake sediments from Morococha, Peruvian Andes. Environ Sci Technol 41:3469-3474

Cooke CA, Abbott MB, Wolfe AP (2008) Late-Holocene atmospheric lead deposition in the Peruvian and Bolivian Andes. Holocene 18:353-359 
Croudace IW, Rindby A, Rothwell RG (2005) ITRAX: description and evaluation of a new X-ray core scanner. In: Rothwell RG (ed) New techniques in sediment core analysis. Geol Soc, London, pp 51-63

Davis OK (1999) Pollen analysis of Tulare Lake, California: Great Basin-like vegetation in Central California during the full-glacial and early Holocene. Rev Palaeobot Palynol 107:249-257

Dorronsoro C, Martin F, Ortiz I, Garcia I, Simon M, Fernandez E, Aguilar J, Fernandez J (2002) Migration of trace elements from pyrite tailings in carbonate soils. J Environ Qual 31:829-835

Emck P (2007) A climatology of south Ecuador-with special focus on the major Andean Ridge as Atlantic-Pacific Climate Divide. Dissertation, Universität Erlangen-Nürnberg

Fægri K, Iversen J (1989) Textbook of pollen analysis, 4th edn. Wiley, Chichester

FAO (2006) Global forest resources assessment 2005, Progress towards sustainable forest management. Food and Agricultural Organization of the United Nations, Rome

Gradstein SR, Kessler M, Lehnert M, Abiy M, Homeier J, Mandl N, Makeschin F, Richter M (2008) Vegetation, climate, and soil of the unique Purdiaea forest of Southern Ecuador. Ecotropica 14:15-26

Grimm EC (1987) CONISS: a Fortran 77 program for stratigraphically constrained cluster analysis by the method of the incremental sum of squares. Comput Geosci 13:13-35

Grimm EC (1991) Tilia v. 2.0.b.4. Illinois State Museum, Research and Collections Center

Grimm EC (2004) Tilia graph v. 2.0.2. Illinois State Museum, Research and Collections Center

Guariguata MR (1990) Landslide disturbance and forest regeneration in the upper Luquillo mountains of Puerto Rico. J Ecol 78:814- 832

Guffroy J (2004) Catamayo precolombino, investigaciones arquelogicas en la provincial de Loja (Ecuador). IRD editions, Paris

Günter S, Stimm B, Cabrera M, Diaz ML, Lojan M, Ordonez E, Richter M, Weber M (2008) Tree phenology in montane forests of southern Ecuador can be explained by precipitation, radiation and photoperiodic control. J Trop Ecol 24:247-258

Guyard H, Chapron E, St-Onge G, Anselmetti FS, Arnaud F, Magand O, Francus P, Mélières MA (2007) High-altitude varve records of abrupt environmental changes and mining activity over the last 4000 years in the Western French Alps (Lake Bramant, Grandes Rousses Massif). Quat Sci Rev 26:2644-2660 
Haberzettl T, Fey M, Lücke A, Maidana N, Mayr C, Ohlendorf C, Schäbitz F, Schleser GH, Wille M, Zolitschka B (2005) Climatically induced lake level changes during the last two millennia as reflected in sediments of Laguna Potrok Aike, southern Patagonia (Santa Cruz, Argentina). J Paleolimnol 33:283-302

Haberzettl T, Wille M, Fey M, Janssen S, Lücke A, Mayr C, Ohlendorf C, Schäbitz F, Schleser G, Zolitschka B (2006) Environmental change and fire history of southern Patagonia (Argentina) during the last five centuries. Quat Int 158:7282

Haberzettl T, Corbella H, Fey M, Janssen S, Lücke A, Mayr C, Ohlendorf C, Schäbitz F, Schleser GH, Wille M, Wulf S, Zolitschka B (2007) Lateglacial and Holocene wet-dry cycles in southern Patagonia: chronology, sedimentology and geochemistry of a lacustrine record from Laguna Potrok Aike, Argentina. Holocene $17: 297-310$

Haberzettl T, Kück B, Wulf S, Anselmetti F, Ariztegui D, Corbella H, Fey M, Janssen S, Lücke A, Mayr C, Ohlendorf C, Schäbitz F, Schleser GH, Wille M, Zolitschka B (2008) Hydrological variability in southeastern Patagonia and explosive volcanic activity in the southern Andean Cordillera during Oxygen Isotope Stage 3 and the Holocene inferred from lake sediments of Laguna Potrok Aike, Argentina. Palaeogeogr Palaeoclimatol Palaeoecol 259:213-229

Hettwer K, Deicke M, Ruppert H (2003) Fens in Karst Sinkholes- Archives for Long Lasting 'Immission' Chronologies. Water Air Soil Pollut 149:363-384

Hiller D, Brümmer GW (1991) Elektronenstrahlanalysen zur Erfassung der Schwermetallbindungsformen in Böden unterschiedlicher Schwermetallbelastung. Mitt Dt Bodenkdl Ges 66:1085- 1088

Homeier J, Werner FA (2008) Spermatophyta. In: Liede-Schumann S, Breckle SW (eds) Provisional checklists of flora and fauna of the San Francisco valley and its surroundings, Southern Ecuador. Ecotrop Monogr 4, pp 15-59

Homeier J, Werner FA, Gradstein SR, Breckle S-W, Richter M (2008) Potential vegetation and floristic composition of Andean Forests in South Ecuador, with a Focus on the RBSF. In: Beck E, Bendix J, Kottke I, Makeschin F, Mosandl R (eds) Gradients in a tropical mountain ecosystem of Ecuador. Ecol Stud 198. Springer, Berlin, Heidelberg, pp 87-100

Hooghiemstra H (1984) Vegetation and climatic history of the High Plain of Bogota, Colombia: a continuous record of the last 3,5 million years. Diss Bot 79, Cramer, Vaduz

INEC (2001) VI censo de población y V de vivienda 2001. Instituto Nacional de Estadistíca y Censos, Quito 
Kessler M (1999) Plant species richness and endemism during natural landslide succession in a perhumid montane forest in the Bolivian Andes. Ecotropica 5:123136

Koinig KA, Shotyk W, Lotter AF, Ohlendorf C, Sturm M (2003) 9000 years of geochemical evolution of lithogenic major and trace elements in the sediment of an alpine lake-the role of climate, vegetation, and land-use history. J Paleolimnol 30:307-320

Lozano PE (2002) Los tipos de bosque en el sur de Ecuador. In: Aguirre Z, Madsen JE, Cotton E, Balsev H (eds) Bótanica Austroecuatoriana. Estudios sobre los recursos vegetales en las provincial de El Oro, Loja y Zamora-Chinchipe. Abya-Yala, Quito, pp 29-49

Lozano P, Delgado T, Aguirre Z (2003) Estado actual de la flora endemica exclusive y su distribucion en el Occidente del Parque Nacional Podocarpus. Funbotanica y Herbario y Jardin Botanico, Loja

Lozano P, Bussmann RW, Küppers M (2005) Landslides as ecosystem disturbancetheir implications and importance in South Ecuador. Lyonia 8:67-72

Marchant R, Almeida L, Behling H, Berrio JC, Bush M, Cleef A, Duivenvoorden J, Kappelle M, De Oliveira P, de Oliveira-Filho AT, Lozano-García S, Hooghiemstra H, Ledru M-P, Ludlow- Wiechers B, Markgraf V, Mancini V, Paez M, Prieto A, Rangel O, Salgado-Labouriau ML (2002) Distribution an ecology of parent taxa of pollen lodged within the Latin American Pollen Database. Rev Palaeobot Palynol 121:1-75

McCormac FG, Hogg AG, Blackwell PG, Buck CE, Higham TFG, Reimer PJ (2004) SHCal04 Southern Hemisphere Calibration 0-11.0 cal Kyr BP. Radiocarbon 46:1087-1092

Mirsal IA (2008) Major Types of Soil Pollutants. In: Mirsal IA (ed) Soil pollution. Origin, monitoring \& remediation. Springer, Berlin, pp 117-136

Moar NT (1970) Recent pollen spectra from three localities in the South Island, New Zealand. NZ J Bot 8:210-221

Neill DA (1999) Vegetation. In: Jørgensen PM, León-Yánez S (eds) Catalogue of the vascular plants of Ecuador. Monogr Syst Bot Missouri Bot Gard 75, pp 13-25

Niemann H, Behling H (2008a) Past vegetation and fire dynamics. In: Beck E, Bendix J, Kottke I, Makeschin F, Mosandl R (eds) Gradients in a tropical mountain ecosystem of Ecuador. Ecol Stud 198. Springer, Berlin, Heidelberg, pp 101-111

Niemann H, Behling H (2008b) Late Quaternary vegetation, climate and fire dynamics inferred from the El Tiro record in the southeastern Ecuadorian Andes. J Quat Sci 23:203-212 
Niemann H, Behling H (2009) Late Pleistocene and Holocene environmental change inferred from the Cocha Caranga sediment and soil records in the southeastern Ecuadorian Andes. Palaeogeogr Palaeoclimatol Palaeoecol 276:1-14

Niemann H, Behling H (2010) Late Holocene environmental change and human impact inferred from three soil monoliths and the Laguna Zurita multi-proxi record in the southeastern Ecuadorian Andes. Veget Hist Archaeobot 19:1-15

Niemann H, Haberzettl T, Behling H (2009) Holocene climate variability and vegetation dynamics inferred from the (11700 cal. yr BP) Laguna Rabadilla de Vaca sediment record, southeastern Ecuadorian Andes. Holocene 19:307-316

Pohle P (2008) The people settled around Podocarpus National Park. In: Beck E, Bendix J, Kottke I, Makeschin F, Mosandl R (eds) Gradients in a tropical mountain ecosystem of Ecuador. Ecol Stud 198. Springer Verlag, Berlin, Heidelberg, pp 25-36

Richardson DM (ed) (2000) Ecology and biogeography of Pinus. University Press, Cambridge

Richter M (2003) Using epiphytes and soil temperature for ecoclimatic interpretations in south Ecuador. Erdkunde 57:161-181

Richter M (2008) Tropical mountain forests-distribution and general features. In: Gradstein SR, Homeier J, Gansert D (eds) The Tropical Mountain ForestPatterns and Processes in a Biodiversity Hotspot. Biodivers Ecol Ser, vol 2, Universitätsverlag Göttingen, pp 7-24

Richter M, Moreira-Muñoz A (2005) Climatic heterogeneity and plant diversity in southern Ecuador experienced by phytoindication. Rev Peru Biol 12:217-238

Rolland N, Larocque I, Francus P, Pienitz R, Laperriere L (2008) Holocene climate inferred from biological (Diptera: Chironomidae) analyses in a Southampton Island (Nunavut, Canada) lake. Holocene 18:229-241

Salomons W, Förstner U (1984) Metals in the hydrocycle. Springer, Berlin-HeidelbergNew York

Sauer W (1971) Geologie von Ecuador, Mit einem Beitrag: Mineralstoffe von Ecuador von Prof. D. Hannfrit Putzer. Bornträger, Berlin, Stuttgart

Schrumpf M, Guggenberger G, Valarezo C, Zech W (2001) Tropical montane rain forest soils. Development and nutrient status along an altitudinal gradient in the south Ecuadorian Andes. Die Erde 132:43-59

Schubert C, Clapperton CM (1990) Quaternary glaciations in the Northern Andes (Venezuela, Colombia and Ecuador). Quat Sci Rev 9:123-135 
Shotyk W, Weiss D, Kramers JD, Frei R, Cheburkin AK, Gloor M, Reese S (2001) Geochemistry of the peat bog at Etang de la Gruère, Jura Mountains, Switzerland, and its record of atmospheric $\mathrm{Pb}$ and lithogenic trace metals ( $\mathrm{Sc}, \mathrm{Ti}, \mathrm{Y}$, Zr, and REE) since 12, 370 14C yr BP. Geochim Cosmochim Acta 65:2337-2360

Shotyk W, Goodsite ME, Roos-Barraclough F, Givelet N, Le Roux G, Weiss D, Cheburkin AK, Knudsen K, Heinemeier J, Knaap WO, van der Norton SA, Lohse C (2005) Accumulation rates and predominant atmospheric sources of natural and anthropogenic $\mathrm{Hg}$ and $\mathrm{Pb}$ on the Faroe Islands. Geochim Cosmochim Acta 69:1-17

Sigg L, Stumm W (1996) Aquatische Chemie. Teubner, Stuttgart

St-Onge G, Mulder T, Francus P, Long B (2007) Chapter two. continuous physical properties of cored marine sediments. In: Hillaire-Marcel C, de Vernal A (eds) Developments in marine geology, Elsevier, pp 63-98

Stuiver M, Reimer PJ (1993) Extended 14C database and revised CALIB radiocarbon calibration program. Radiocarbon 35:215- 230

Swedish Environmental Systems (1999) Monitoreo ambiental de las áreas mineras en el sur del Ecuador entre 1996 y 1998. Ministerio de Energía y Minas, Quito, Ecuador

Tarras-Wahlberg NHK, Flachier A, Fredriksson GR, Lane S, Lundberg B, Sangfors O (2000) Environmental impact of small-scale and Artisanal Gold Mining in Southern Ecuador. Ambio 29:484-491

Telford RJ, Heegaard E, Birks HJB (2004) The intercept is a poor estimate of a calibrated radiocarbon age. Holocene 14:296-298

Weng C, Bush MB, Silman MR (2004a) An analysis of modern pollen rain on an elevational gradient in southern Peru. J Trop Ecol 20:113-124

Weng C, Bush MB, Chepstow-Lusty AJ (2004b) Holocene changes of Andean alder (Alnus acuminata) in highland Ecuador and Peru. J Quat Sci 19:685-691

Wilcke W, Valladarez H, Stoyan R, Yasin S, Valarezo C, Zech W (2003) Soil properties on a chronosequence of landslides in montane rain forest, Ecuador. Catena 53:79-95

Wilcke W, Yasin S, Schmitt A, Valarezo C, Zech W (2008) Soils along the altitudinal transect and in catchments. In: Beck E, Bendix J, Kottke I, Makeschin F, Mosandl R (eds) Gradients in a tropical mountain ecosystem of Ecuador. Ecol Stud 198. Springer, Berlin, Heidelberg, pp 75-85

Wunder S (2000) The economics of deforestation: the example of Ecuador. St. Martin, New York 


\title{
Chapter 4 .
}

\section{Reconstruction and visualization of upper forest line and vegetation changes in the Andean depression region of southeastern Ecuador since the last glacial maximum - a multi-site synthesis}

\author{
Brunschön, C. and Behling, H. \\ submitted to Review of Palaeobotany and Palynology
}

\subsection{Abstract}

Based on 5 pollen records from locations between ca. 2700-3300 $\mathrm{m}$ a.s.l. in the Podocarpus National Park (PNP) area (ca. $4^{\circ} \mathrm{S}$ and $79^{\circ} \mathrm{W}$ ) within the Andean depression region in southern Ecuador, we reconstructed and visualized upper forest line (UFL) dynamics and past vegetation changes since the last glacial maximum (LGM). Estimates of altitudinal ranges of past UFL shifts in the study area allowed reconstructing past changes of forest and páramo expansion in the study region. During the LGM, the UFL position in the PNP area was at least ca. $700 \mathrm{~m}$ lower in the northernmost part and ca. $250 \mathrm{~m}$ further south compared to today. Glaciers covered the central PNP at this time, while deglaciation completed with the beginning of the Holocene. Throughout the recorded time UFL shifts and vegetation changes in the study area showed considerable local differences. This can be explained by locally differing vegetation compositions and climatic conditions, but especially during early to late Holocene times also by human disturbances. Only during the earliest Holocene and mid-Holocene the UFL in the central and southern PNP area reached slightly higher elevations up to $200 \mathrm{~m}$ above the present position. The UFL in the PNP area shifted attitudinally over a shorter interval compared to other sites outside the depression. This difference may be caused by the study regions relatively low mountain elevations, wet climatic conditions, different and diverse vegetation patterns as well as by the corresponding vegetation response to climatic changes. The high complexity and heterogeneity of Andean habitats are assumed to be responsible for the variety in altitudinal distribution and compositional changes of vegetation. In the PNP area and the Andean depression region temperature seems to be less important for the UFL and vegetation changes than in other regions of the northern Andes. Instead we assume that other drivers, e.g. precipitation and wind, may be much more important for the developments in our study region.

Keywords: late Quaternary, páramo, mountain rainforest, upper forest line, Andean depression, Ecuador 


\subsection{Introduction}

The tropical eastern Andes are recognized as one of the most important biodiversity hotspots on earth regarding vascular plant species richness (Barthlott et al., 2005). Specifically the tropical mountain rainforests have an exceptionally high plant diversity (Richter, 2008) and thus are of major research interest (e.g. Beck et al., 2008a). These mountain forests, however, are among the most threatened ecosystems in the tropical Andes because of disturbance due to human impact (Gentry, 1995). In the northern Andes only 5-10\% of the original forest is estimated to have remained intact (Henderson et al., 1991). Among all South American countries, Ecuador currently suffers from the highest deforestation rates (Mosandl et al., 2008).

Multiple factors including complex topography and regionally diverse climatic conditions contribute to the exceptional biodiversity in the tropical Andes of southern Ecuador. Past climate changes as well as tectonism influenced the degree of plant diversification (Richter et al., 2009). Therefore, the knowledge of origin and past spatio-temporal dynamics of mountain rainforest are important issues in biodiversity research. Additionally, palaeoecological studies can provide insight into vegetation changes to be expected under future climate change. Mountain regions provide excellent conditions for the study of past climatic changes because of the close relationship between climate and environment (Gosling and Bunting, 2008). To assess questions related to the topic of ecosystem behavior and climate change we studied late Quaternary environmental changes in mountain ecosystems of the eastern Andes in southern Ecuador.

The global biodiversity hotspot of the tropical Andes is represented on a local scale by high species diversity within the mountain ecosystems of the Podocarpus National Park (PNP) area (Beck and Richter, 2008), which is the region of our focus in this study. Even the upper forest line (UFL) ecotone in this area is characterized by high species richness compared to other sites in the northern Andes, where the UFL show a species composition of low diversity (Peters, 2009). Although the high plant diversity within the study area poses a challenge for palynological research, it likewise offers a unique opportunity to determine the role ice ages may have played on plant diversity.

There are only few palaeoecological records in mountain forests of the Andean region not at least because of difficult access and scarcity of natural archives (Bush et al., 2007). In the northern Andes significant discrepancies exist between estimates of the last glacial maximum (LGM) temperature depression and vegetation changes (Wille et al., 2001). With respect to forest line dynamic in the northern Andes there is no consensus about what happened during the Holocene (Di Pasquale et al., 2008). In the Andean depression region, which includes our study area, studies on vegetation history and UFL changes are even fewer than in other regions. Here, climatic conditions, vegetation composition and UFL structure are considerably different from regions outside the Andean depression (Emck, 2007; Peters, 2009), and thus vegetation history and palaeoclimate may differ from nearby regions.

In order to fill the gap in our knowledge of past ecosystem history for the Andean depression region, several palaeoecological analyses of sediment cores, obtained from sites at elevations up to $3300 \mathrm{~m}$ a.s.l. within the wider PNP region, were recently 
analyzed (e.g. Brunschön and Behling 2009; Brunschön et al., 2010; Niemann and Behling, 2007, 2009, 2010; Niemann et al., 2009, Rodríguez and Behling, 2010). The main objective of this study is to summarize the results of these analyses of fossil pollen data for the PNP area and to reconstruct regional vegetation changes since the LGM with a focus on UFL dynamics. Reconstructing changes of the climatic-sensitive UFL, may allow quantifying past climatic changes (Tinner, 2007) and to specifiy the drivers behind. Therefore, we provide an estimate of the range of UFL shifts based on the available pollen data. This study aims to enhance the general understanding of the past behavior of the tropical UFL and of the processes influencing vegetation and UFL changes. To visualize the changes in the pollen records images of past landscapes and vegetation patterns are reconstructed for certain time intervals. Particular questions in relation to the Andean depression region are: (1) Was the relatively low UFL ever higher than today? (2) How comparable is late Quaternary vegetation history between the Andean depression and areas beyond? (3) What were the triggering factors for vegetation changes and were they the same for all regions? The answers to these questions are of interest also for the development of management strategies in the PNP. Specifically in terms of reforestation the natural distribution limits of forest and of páramo should be considered (Bakker et al., 2008).

\subsection{Environmental settings of the study area}

\section{Location}

The area of interest for the vegetation reconstruction is the PNP region (ca. $4^{\circ} \mathrm{S}$ and $79^{\circ} \mathrm{W}$ ), located in the Girón-Cuenca and Huancabamba Andean depression of the eastern Andean range of the Cordillera Real of southern Ecuador (Fig. 4.1). This depression region extends from southern Ecuador to northern Peru (lat. $3^{\circ}-7^{\circ} \mathrm{S}$ ). The highest peaks reach a maximum of ca. $3900 \mathrm{~m}$ a.s.l.; active volcanoes and glaciers are absent. The area of the PNP extends from ca. $900 \mathrm{~m}$ up to ca. $3800 \mathrm{~m}$ a.s.l., mainly on the eastern slopes of the Cordillera Real. The major cities Loja and Zamora are near the northern limits of the PNP (Fig. 4.1). Currently available pollen records within the study region were taken inside the PNP as well as in surrounding areas. Five records from four different locations were used for the regional reconstruction (Fig. 4.1, Table 4.1): El Tiro (2811 m a.s.l.), Laguna Cocha Caranga (2719 m a.s.l.), Laguna Rabadilla de Vaca (3312 m a.s.l.) and Cerro Toledo (3110 and $3150 \mathrm{~m}$ a.s.l.). The distance between the northernmost (El Tiro) and southernmost (Cerro Toledo) study site is ca. $43 \mathrm{~km}$. El Tiro and Cerro Toledo sites are bogs (Niemann and Behling, 2007; Brunschön and Behling, 2009), whereas the sites of Laguna Cocha Caranga and Rabadilla de Vaca are small lakes with $2 \mathrm{~m}$ and $5 \mathrm{~m}$ water depth, respectively (Niemann and Behling, 2009; Niemann et al., 2009). 

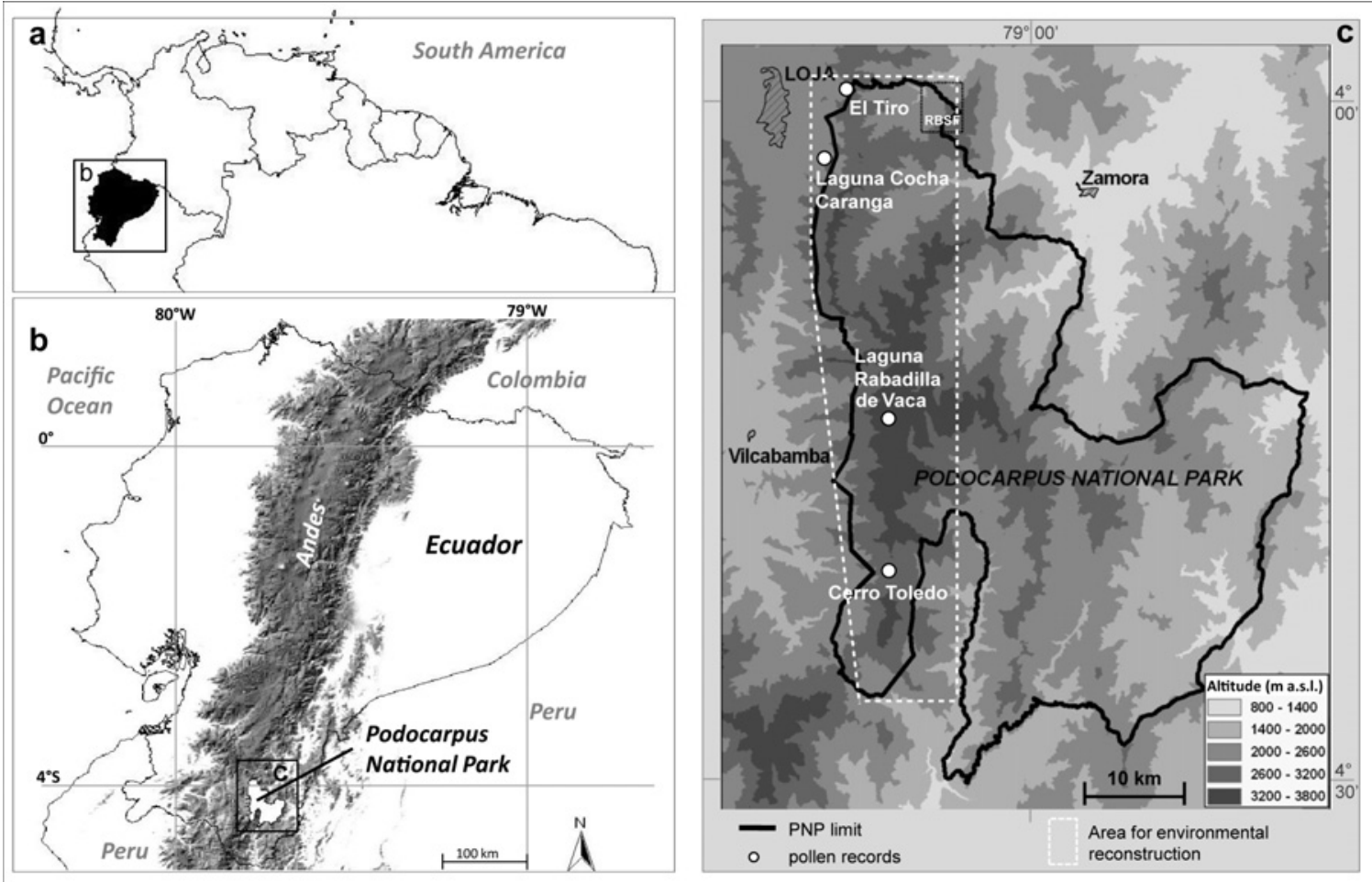

Figure 4.1. Map showing (a) the location of Ecuador in South America and (b) the Ecuadorian Andes as shaded area. (b) The Podocarpus National Park (PNP) position in the southeastern Ecuadorian Andes is shown as overview and (c) in detail with topographic information. The pollen records in the PNP area suitable for the reconstruction are displayed (c) and located at following elevations: El Tiro: $2811 \mathrm{~m}$ a.s.l., Laguna Cocha Caranga: $2719 \mathrm{~m}$ a.s.l., Laguna Rabadilla de Vaca: $3312 \mathrm{~m}$ a.s.l., Cerro Toledo (CT/CTB): 3150/3110 m a.s.l.; position of pollen sites determine the spatial extension ((c) see dotted white line) of the reconstruction area. 
Table 4.1. Site specific data of pollen records obtained within the Podocarpus National Park area and used for the vegetation reconstruction reaching back to the LGM (ca. 20,000 cal yr BP).

\begin{tabular}{|c|c|c|c|c|c|c|}
\hline Pollen record & $\begin{array}{l}\text { Elevation } \\
\text { (m a.s.l.) }\end{array}$ & $\begin{array}{l}\text { Site } \\
\text { coordinates }\end{array}$ & $\begin{array}{l}\text { PNP } \\
\text { location }\end{array}$ & $\begin{array}{l}\text { Vegetation } \\
\text { type }\end{array}$ & $\begin{array}{l}\text { reflected } \\
\text { time period } \\
(\text { cal yr BP) }\end{array}$ & $\begin{array}{l}\text { No. } \\
{ }^{14} \text { C-datings }\end{array}$ \\
\hline El Tiro ${ }^{a}$ & $2811 \mathrm{~m}$ & $\begin{array}{l}03^{\circ} 50^{\prime} 25.9^{\prime \prime} \mathrm{S} \\
79^{\circ} 80^{\prime} 43.2^{\prime \prime} \mathrm{W}\end{array}$ & north & subpáramo & 20,000 & 5 \\
\hline $\begin{array}{l}\text { Laguna Cocha } \\
\text { Caranga } b\end{array}$ & $2719 \mathrm{~m}$ & $\begin{array}{l}04^{\circ} 02^{\prime} 45.1^{\prime \prime} \mathrm{S} \\
79^{\circ} 09^{\prime} 34.5^{\prime \prime} \mathrm{W}\end{array}$ & north & (sub)páramo & 14,000 & 3 \\
\hline $\begin{array}{l}\text { Laguna } \\
\text { Rabadilla de Vaca }\end{array}$ & $3312 \mathrm{~m}$ & $\begin{array}{l}04^{\circ} 15^{\prime} 19.7^{\prime \prime} \mathrm{S} \\
79^{\circ} 06^{\prime} 43.7^{\prime \prime} \mathrm{W}\end{array}$ & center & páramo & 11,500 & 4 \\
\hline $\begin{array}{l}\text { Cerro Toledo } \mathrm{d} \\
(\mathrm{CT} / \mathrm{CTB})\end{array}$ & $\begin{array}{l}3110 \mathrm{~m} / \\
3150 \mathrm{~m}\end{array}$ & $\begin{array}{l}04^{\circ} 22^{\prime} 28.6^{\prime \prime} \mathrm{S} \\
79^{\circ} 06^{\prime} 41.5^{\prime \prime} \mathrm{W}\end{array}$ & south & $\begin{array}{l}\text { páramo/ } \\
\text { subpáramo }\end{array}$ & 20,000 & 7 \\
\hline
\end{tabular}

\section{Climate}

The climate of Ecuador, including the study area, is characterized by the tropical trade wind regime with strong easterlies throughout the year. Moist air masses ascend from the Amazon basin and east of the Cordillera Real precipitation and humidity rise continuously to the crest regions, where the Andean range acts as climatic divide (Bendix et al., 2008a/b; Emck, 2007). The moist conditions of the Amazon-exposed eastern side contrast with the (semi-) arid climate of the western side of the range. Rainfall of up to $8000 \mathrm{~mm} \mathrm{a}^{-1}$ in crest regions drops in the Inter-Andean basin to a minimum of $300 \mathrm{~mm} \mathrm{a}^{-1}$ in less than $30 \mathrm{~km}$ distance (Bendix et al., 2008a; Emck, 2007). The main rainy season lasts from April to August (austral winter), although rainfall is high throughout the year. On average, 11-12 humid months are recorded for the eastern escarpment, decreasing to 9-10 humid month on the western slopes at the Loja region. Air temperature is governed by topography, altitude and ocean temperatures (Beck et al., 2008b) and varies according to the time of day and season (Bendix et al., 2008a). The altitudinal gradient of mean annual temperature ranges from ca. $19-25{ }^{\circ} \mathrm{C}$ below $1100 \mathrm{~m}$ a.s.l. to ca. $6-13{ }^{\circ} \mathrm{C}$ at elevations between 2200 and $3800 \mathrm{~m}$ a.s.l. (Richter, 2003; Beck et al., 2008b). Night frosts are rare and only occur during clear mornings and after clear nights at elevations above $3000 \mathrm{~m}$ a.s.l. (Emck, 2007). El Niño-Southern Oscillation (ENSO) climate patterns do not have a noteworthy effect, as the mountain ranges shelter the region from Pacific air masses (Bendix et al., 2008b).

\section{Modern vegetation}

With a focus on the Reserva Biológica San Franscisco (RBSF) in the northern PNP (Fig. 4.1), Homeier et al. (2008) described the potential natural vegetation distribution of seven major vegetation types in the wider PNP area (Table 4.2). Because of the high plant diversity, the boundaries between vegetation types are not sharp and the distribution limits vary locally. Thus, the given altitudinal ranges have to be 
Table 4.2. Potential natural vegetation types in the Podocarpus National Park area described by Homeier et al. (2008).

\begin{tabular}{|c|c|c|c|c|c|}
\hline & Vegetation type & Abbr. & Slope & $\begin{array}{l}\text { Distribution } \\
\text { (m a.s.l.) }\end{array}$ & Description \\
\hline 1 & Premontane rainforest & $\mathrm{PMF}$ & east & ca. $800-1300$ & Forest with trees up to $40 \mathrm{~m}$ height \\
\hline 2 & $\begin{array}{l}\text { Semidecidous } \\
\text { interandean forest }\end{array}$ & SDF & west & ca. $1400-2400$ & $\begin{array}{l}\text { Forest with trees up to } 15 \mathrm{~m} \text { height, } \\
\text { emergents occasionally up to } 20 \mathrm{~m}\end{array}$ \\
\hline 3 & Lower montane forest & $\mathrm{LMF}$ & east & ca. $1300-2100$ & Forest with trees up to $30 \mathrm{~m}$ height \\
\hline 4 & Upper montane forest & UMF & east & ca. $2100-2700$ & Forest with trees up to $25 \mathrm{~m}$ height \\
\hline 5 & Upper montane forest & & west & ca. $2400-2800$ & Forest with trees up to $20 \mathrm{~m}$ height \\
\hline 6 & $\begin{array}{l}\text { Elfin forest with } \\
\text { subtype subpáramo }\end{array}$ & & $\begin{array}{l}\text { east/ } \\
\text { west }\end{array}$ & ca. $2700-3100$ & $\begin{array}{l}\text { Forest forming the upper forest line } \\
\text { (UFL) with trees of } 6-8 \mathrm{~m} \text { height; sub- } \\
\text { páramo is above the UFL and largely } \\
\text { dominated by shrubs (trees of max. } 5 \mathrm{~m} \\
\text { height occur) }\end{array}$ \\
\hline 7 & Páramo & & crests & ca. $3100-3700$ & $\begin{array}{l}\text { Shrub and dwarf bamboo páramos above } \\
\text { the UFL, vegetation heights up to } 2 \mathrm{~m}\end{array}$ \\
\hline
\end{tabular}

considered as approximate limits (Homeier et al., 2008; Richter et al., 2009). Heterogeneous environmental conditions as well as multiple disturbance regimes cause the extraordinary high diversity in the area. The present vegetation is highly degraded around the PNP due to deforestation and land conversion into pastures and cultivations (Beck et al., 2008b). Currently, disturbance is restricted to the surrounding areas and some border zones of the PNP. The presented pollen record sites are located in the uppermost vegetation types of subpáramo and páramo (Table 4.2). The fossil pollen data of these records also contain taxa from lower vegetation types such as upper montane forest (UMF) and lower montane forest (LMF), whereas pollen types originating of premontane rainforest $(\mathrm{PMF})$ and semideciduous interandean forest (SDF) taxa are scarce. Today, the El Tiro site is characterized by subpáramo vegetation (Niemann and Behling, 2007) very close to the UFL. Subpáramo vegetation, mainly dominated by shrubs and dwarf trees, may be considered part of the UFL ecotone, especially where UFL ecotones are characterized by gradually decreasing tree height (Bader, 2007). In our study region, subpáramo is generally defined to extend above the UFL, but is considered as subtype of elfin-forest, which forms the UFL in the study area (Homeier et al., 2008; Table 4.2). Although Laguna Cocha Caranga is located on the western escarpment in the potential area of the UMF, the site is covered with shrubby and grassy vegetation, which can be associated with subpáramo and páramo vegetation related to human interventions. Forest patches are found in immediate vicinity of the small lake. The lower slopes near Cocha Caranga are currently used for pastures and closed forest occurs only to the southeast of the lake (Niemann and Behling, 2009). The highest site of Laguna Rabadilla de Vaca is situated within páramo vegetation. The lakeside is dominated by herbs and grasses, while the surrounding slopes are covered with shrub páramo (Niemann et al., 2009). The Cerro Toledo area, near the crest region, is covered with grass and shrub páramo (Brunschön and Behling, 2009). 


\section{Upper forest line}

The UFL, the maximum elevation where closed forest occurs (Bakker et al., 2008), is highly variable in the Andean depression and less investigated than other neotropical forest limits (Richter et al., 2008). Further north and south of the depression region, the UFL reaches elevations of $4000 \mathrm{~m}$ a.s.l. or more, whereas the UFL in southern Ecuador is comparatively low (Richter and Moreira-Muñoz, 2005; Beck et al., 2008c). In our study area the lowest elevation of the UFL is found at El Tiro between 2790$2820 \mathrm{~m}$ a.s.l. and the highest at ca. 3145-3355 $\mathrm{m}$ a.s.l. at Rabadilla de Vaca with an intermediate UFL elevation of ca. $3030-3280 \mathrm{~m}$ a.s.l. at Cerro Toledo. The altitudinal position of the UFL often differs between the western and eastern slopes. Sharp boundaries as well as gradual transition zones between forest and treeless vegetation, sometimes with forest patches, are found above the UFL. The low UFL position in the central Andean depression is formed by a species-rich forest, which lacks the elsewhere dominant UFL genus Polylepis (Peters, 2009; Beck et al., 2008c). Strong winds and extremely high precipitation are suggested to be the main factors for the absence of Polylepis, because the genus tends to avoid perhumid regions (Kessler, 1995; Richter and Moreira-Muñoz, 2005).

\subsection{Material and Methods}

\section{Palynological data}

Palynological studies within the PNP region are based on 15 pollen records. Five are suitable for the comprehensive vegetation and UFL reconstruction in the PNP area extending back to the LGM (Fig. 4.1, Table 4.1), whereas the other 10 records cover only late Holocene times (Brunschön et al., 2010; Matthias, 2008; Niemann and Behling, 2009, 2010; Rodríguez and Behling, 2010). The sites El Tiro (Niemann and Behling, 2007) and Laguna Cocha Caranga (Niemann and Behling, 2009) are located near the northern limit of the PNP. The record of Laguna Rabadilla de Vaca (Niemann et al., 2009) was obtained from the central PNP. In the southern part of the PNP at the Cerro Toledo site (Brunschön and Behling, 2009) two cores (CT and CTB) were taken. Two of these records (El Tiro and Cerro Toledo) reach back to the LGM (ca. 20,000 cal yr BP), while the other three cover the Holocene (Table 4.1. Fig. 4.2). Ages obtained by linear interpolation are assumed to be reliable for the comparison. The radiocarbon dates were calibrated primarily using the CalPal online system (Weninger et al., 2004) with the CalPal-2007-Hulu calibration curve. Only for the analysis of the Rabadilla de Vaca record the CALIB 5.0.2 version (Stuiver and Reimer, 1993) with the shcal04 (McCormac et al., 2004) calibration curve was applied (Table 4.3). This results in a positive offset of ca. 55-140 cal yr BP for the ages of the Rabadilla de Vaca record compared to the other ages. However, this discrepancy can be neglected here, as we adopted a relatively low temporal resolution for the reconstruction (time steps between thousands of years). 
Table 4.3. Radiocarbon dates of to the pollen records included in the vegetation reconstruction and applied calibration methods.

\begin{tabular}{|c|c|c|c|c|c|c|}
\hline \multirow[t]{2}{*}{ Pollen record } & \multirow[t]{2}{*}{$\begin{array}{l}{ }^{14} \text { C Age } \\
(y \mathbf{r} \text { BP })\end{array}$} & \multirow{2}{*}{$\begin{array}{l}\text { Calibrated } \\
\text { age } \\
(\text { cal yr BP })^{a}\end{array}$} & \multicolumn{2}{|c|}{ Calibrated age range (cal yr BP) } & \multirow[t]{2}{*}{$\begin{array}{l}\text { Calibration } \\
\text { program }\end{array}$} & \multirow[t]{2}{*}{$\begin{array}{l}\text { Calibration } \\
\text { curve }\end{array}$} \\
\hline & & & 1- $\sigma$ range & 2- $\sigma$ range & & \\
\hline \multirow[t]{5}{*}{ El Tiro } & $1828 \pm 55$ & 1770 & $1704-1830$ & & \multirow[t]{5}{*}{$\mathrm{CalPal}^{\mathrm{b}}$} & \multirow{5}{*}{$\begin{array}{l}\text { CalPal- } \\
2007- \\
\text { Hulu }\end{array}$} \\
\hline & $2972 \pm 43$ & 3160 & $3085-3225$ & & & \\
\hline & $7850 \pm 71$ & 8720 & $8582-8844$ & & & \\
\hline & $11,187 \pm 104$ & 13,080 & $12,943-13,221$ & & & \\
\hline & $16,517 \pm 128$ & 19,840 & $19,530-20,142$ & & & \\
\hline Lag. Cocha & $1208 \pm 48$ & 1150 & $1079-1219$ & & \multirow[t]{3}{*}{ CalPal } & CalPal- \\
\hline \multirow[t]{2}{*}{ Caranga } & $7413 \pm 52$ & 8260 & $8198-8314$ & & & 2007- \\
\hline & $10,636 \pm 38$ & 12,570 & $12,429-12,709$ & & & Hulu \\
\hline \multirow{4}{*}{$\begin{array}{l}\text { Lag. Rabadilla } \\
\text { de Vaca }\end{array}$} & $1887 \pm 38$ & 1770 & & $1630-1875$ & \multirow{4}{*}{$\begin{array}{l}\text { CALIB }^{\mathrm{C}} \\
5.0 .2\end{array}$} & \multirow[t]{4}{*}{ shcal04 $^{\mathrm{d}}$} \\
\hline & $4603 \pm 45$ & 5170 & & 4990-5445 & & \\
\hline & $6822 \pm 88$ & 7620 & & $7460-7790$ & & \\
\hline & $9262 \pm 81$ & 10,380 & & $10,225-10,555$ & & \\
\hline \multirow{5}{*}{$\begin{array}{l}\text { Cerro Toledo } \\
\text {-CT }\end{array}$} & $271 \pm 48$ & 360 & $287-424$ & & \multirow[t]{7}{*}{ CalPal } & \multirow{7}{*}{$\begin{array}{l}\text { CalPal- } \\
2007- \\
\text { Hulu }\end{array}$} \\
\hline & $4280 \pm 35$ & 4850 & $4841-4867$ & & & \\
\hline & $8101 \pm 52$ & 9060 & $9000-9112$ & & & \\
\hline & $12,627 \pm 100$ & 14,990 & $14,659-15,308$ & & & \\
\hline & $16,778 \pm 137$ & 20,000 & $19,687-20,310$ & & & \\
\hline \multirow[t]{2}{*}{-CTB } & $2245 \pm 30$ & 2260 & $2192-2321$ & & & \\
\hline & $4435 \pm 35$ & 5100 & $4972-5216$ & & & \\
\hline
\end{tabular}

\section{Pollen analysis and data presentation}

Chemical treatment of subsamples of all pollen records used for this reconstruction was consistent, as standard pollen analytical methods (Fægri and Iversen, 1989) were applied. For all records, pollen and spores were counted up to a minimum pollen sum of 300 grains per sample. Pollen identification was based on the reference collections of Colombia (Hooghiemstra, 1984) and the Neotropics and Ecuador, kept at the University of Göttingen (Behling, 1993). The classification of pollen types in ecological groups was uniformly derived from the regional vegetation description of Homeier et al. (2008) and additional vegetation studies (Aguirre et al.; 2003; Bussmann 2001, 2005; Lozano, 2002; Lozano et al., 2003; Richter, 2003). For a combined diagram all data were plotted against a linear age scale (Fig. 4.2) with TILIAgraph (Grimm, 2004).

\section{Spatio-temporal scope for the reconstruction}

Palynological data availability for the PNP region defines the scope and resolution of the environmental reconstruction. Pollen record sites are evenly distributed in north-south direction for the area under investigation. However, in the western PNP all sites are located at high elevations between ca. 2700-3300 m a.s.l. (Fig. 4.1). So far, no records are available from the lower elevations in the eastern and western portion. As pollen dispersal in this area is influenced by strong easterly winds, pollen found in the records originates predominantly from vegetations on the eastern slopes 
(Niemann et al., 2010). Pollen of lower vegetation on the western side, e.g. from $\mathrm{SDF}$, is barely found. Hence, spatial distribution for the environmental reconstruction is assumed to be valid for the crest regions and highest elevations down to ca. $2100 \mathrm{~m}$ a.s.l. and $2400 \mathrm{~m}$ a.s.l. on the eastern and western escarpment, respectively (Fig. 4.1). Lower elevation vegetation types (LMF, SDF and PMF, Table 4.2) cannot be reconstructed and visualized adequately at this point. To illustrate past regional environments we assume analogous conditions between the data points. We concentrated the environmental reconstruction of past UFL and vegetation changes at time slices at ca. 20,000, 15,500, 10,500, 8500, 6000 and 3000 cal yr BP (Fig. 4.2).

\section{Upper forest line reconstruction}

Estimated shifts of past UFL positions are based on changing arboreal pollen (AP) percentages, which are reflected in the fossil pollen records by proportional changes in LMF, UMF and subpáramo (AP) versus páramo (non-AP). The same was done in other studies in Colombia and Ecuador (Bakker et al., 2008; Hooghiemstra, 1984; van der Hammen and González, 1960). To reconstruct altitudinal UFL shifts present-day key information was assembled for the study area. This includes analysis of pollen representation in top soil samples of all 15 pollen records within the PNP area. Mean values of AP percentages in these samples indicate an offset of $20 \%$ between páramo and UFL sites at a vertical distance of ca. $100 \mathrm{~m}$. This value was supported by pollen rain study from the northern PNP (Niemann et al., 2010). In that analysis difference between AP proportions of páramo versus subpáramo sites (subpáramo includes here the UFL ecotone) was $45 \%$ at an altitudinal distance of ca. $260 \mathrm{~m}$. This results in a similar value of ca. $20 \%$ AP offset with every $110-120 \mathrm{~m}$ of altitudinal distance. However, it needs to be noted that the data for these estimates include samples, which in part reflect present disturbance regimes. Considering also the very steep slopes of our study area (Beck et al., 2008b) a more realistic reconstruction of altitudinal UFL changes is obtained by using ca. $100 \mathrm{~m}$ UFL shift for every $10 \%$ change in AP. Pollen data showing the absence or presence of characteristic taxa of the lower and therefore warmer LMF vegetation zone support this estimate (see later in section 4.5). Evidence for the past UFL positions also comes from studies of past glacier extensions in the southeastern Ecuadorian Andes (Heine, 2000; Rozsypal, 2000). Certainly, the measure has to be used with much caution as it is based on a back-of-the envelope calculation. 


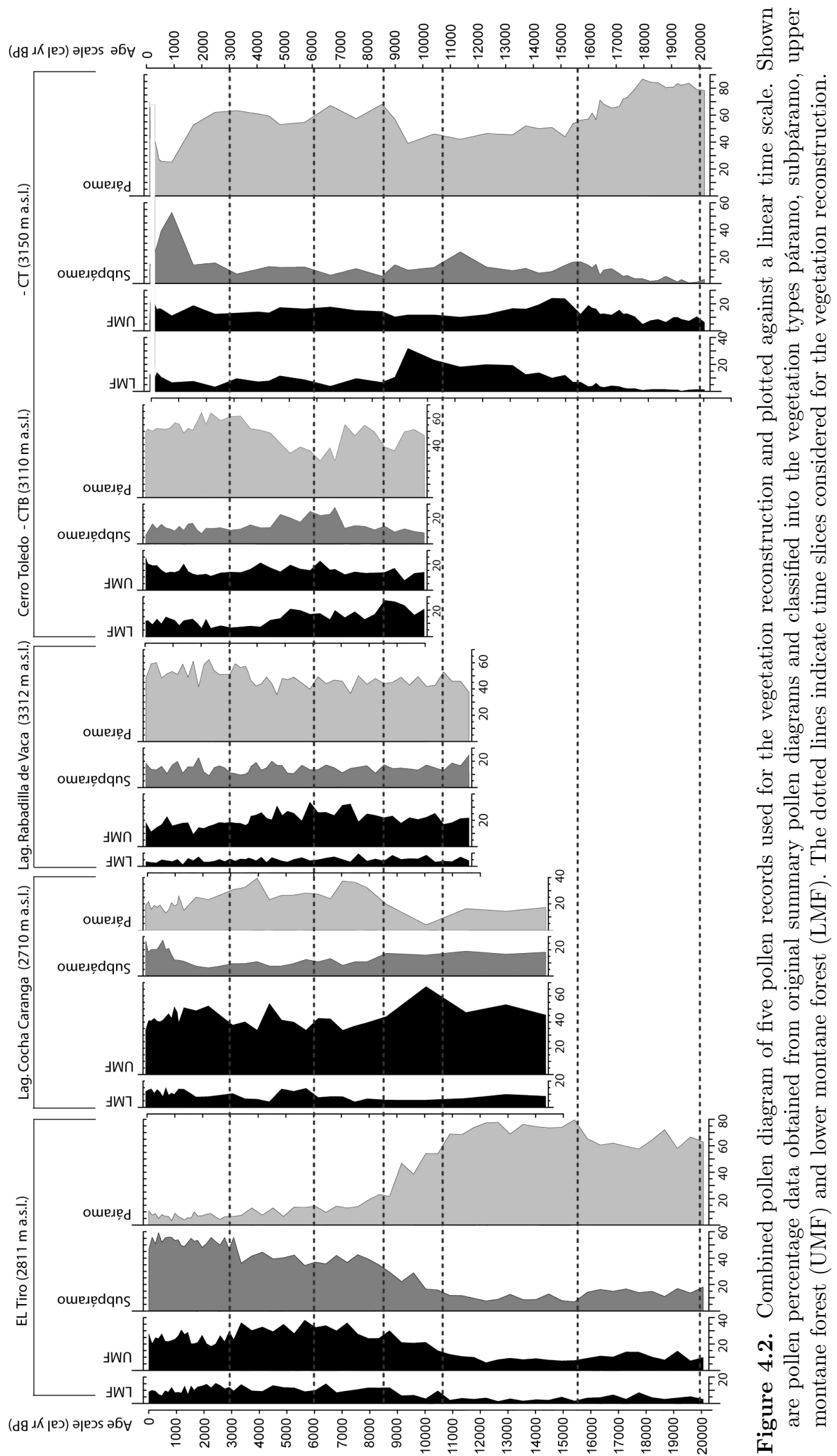




\subsection{Description of fossil pollen records}

In the following we describe the summarized fossil pollen data of the five records (Fig. 4.2). For a detailed description of pollen data, we refer to the original data sources (Niemann and Behling, 2007, 2009; Niemann et al., 2009; Brunschön and Behling, 2009). The UFL ecotone is represented in the pollen records within both vegetation types of UMF and subpáramo. Pollen assemblages of all records show for subpáramo vegetation very high percentages of Melastomataceae. In the RBSF, Melastomataceae is one of the most species-rich families (55 species, 10 genera), occurring over a large altitudinal range (Homeier and Werner, 2007; Homeier et al., 2008). A modern pollen rain study in the RBSF shows nearly identical proportions of Melastomataceae pollen at elevations between 1920 and $3185 \mathrm{~m}$ a.s.l. (Niemann et al., 2010). Thus, vegetation changes and especially UFL dynamics are traced best by contrasting the summarized pollen assemblages of the vegetation types of LMF, UMF and subpáramo (mainly represented by AP) with the treeless páramo vegetation (only non-AP). The following description is restricted to these changes and the selected time slices (Fig. 4.2).

\section{$\operatorname{LGM}($ ca. 20,000 cal yr BP)}

The two records reaching back to the LGM show for this time high percentages in páramo pollen taxa. At the higher elevation site of Cerro Toledo (CT record) páramo pollen values reach ca. $80 \%$ compared to ca $65 \%$ of the lower elevation El Tiro site. Thus, AP proportions are comparably low. At Cerro Toledo pollen proportions of subpáramo, UMF and LMF reach a maximum of 12\%. At El Tiro almost $30 \%$ is represented by AP but mainly of subpáramo pollen taxa.

\section{Late glacial (ca. 15,500 cal yr BP)}

At the El Tiro site pollen proportions during late glacial times are similar to those of LGM times. Páramo pollen taxa reach $70-80 \%$ and combined values of subpáramo, UMF and LMF pollen remain relatively stable with ca. 25\%. Compared to the LGM páramo pollen percentages at Cerro Toledo (CT record) decrease to ca. 50\%, while subpáramo, UMF and LMF pollen taxa synchronously increase to a total value of ca. $40 \%$.

\section{During the earliest Holocene (ca. 10,500 cal yr BP)}

Four pollen records document the initial phase of the Holocene. At El Tiro páramo pollen frequency decreases to ca. $50 \%$, while pollen taxa of subpáramo, UMF, LMF reach higher values of ca. 35\%. The same trend is observed at Cerro Toledo (CT record) where páramo pollen abundance decreases to ca. $40 \%$, while pollen taxa of subpáramo, UMF and LMF sum up to ca. 50\%. At Cocha Caranga, the lowest site, páramo is reflected by pollen proportions of ca. 10-20\%, while pollen of subpáramo, UMF and LMF show high values of ca. 80\%. UMF pollen constitutes the main component of 40-60\%. Data from Laguna Rabadilla de Vaca, the highest elevation 
site, show values of ca. $45 \%$ for páramo pollen taxa on one hand and subpáramo, UMF and LMF pollen taxa on the other hand.

\section{Early Holocene (ca. 8500 cal yr BP)}

During the early Holocene, a significant change is observed at El Tiro with pollen taxa of páramo decreasing to 20-25\% and pollen of subpáramo, UMF and LMF increasing to $70 \%$. At the nearby site of Laguna Cocha Caranga, changes are opposite as pollen proportions of páramo increase to ca. $30 \%$ and subpáramo, UMF and LMF pollen taxa reach together ca. 60\%. Pollen percentages of the Laguna Rabadilla de Vaca record remain at the same levels as in the previous time period. Data from Cerro Toledo (CT record) show similar changes to Cocha Caranga. Proportions of páramo pollen increase to ca. 60-70\%, while pollen taxa of subpáramo, UMF and LMF decrease and reach a maximum of ca. 30\%. At ca. $40 \mathrm{~m}$ lower elevations at Cerro Toledo (CTB record), páramo pollen shows values of $40-50 \%$ and combined pollen taxa of subpáramo, UMF and LMF reach almost $50 \%$.

\section{Mid-Holocene (ca. 6000 cal yr BP)}

Compared to the early Holocene, in mid-Holocene times páramo pollen frequency shows at El Tiro lower values of ca. 15\%. Pollen taxa of subpáramo, UMF and LMF reach here values of ca. $80 \%$ during this time. At Laguna Cocha Caranga, pollen proportions remain almost the same. Percentages of páramo pollen show values of ca. $25 \%$ and pollen taxa of subpáramo, UMF and LMF persist with ca. 60\%. At Laguna Rabadilla de Vaca little changes are observed. Pollen taxa of páramo decrease to ca. 40\%, while subpáramo, UMF and LMF pollen percentages reach almost 50\%, mainly reflected by UMF taxa. Pollen data of the higher part (CT record) at Cerro Toledo show no considerable change since the early Holocene. Small changes can be observed at the lower site (CTB record), where páramo pollen proportions decrease to ca. 30-35\% and subpáramo, UMF and LMF pollen taxa are represented by ca. $60 \%$.

\section{Late Holocene (ca. 3000 cal yr BP)}

Data for the late Holocene show that at El Tiro páramo pollen taxa reach their lowest values of ca. 10\%, while subpáramo, UMF and LMF pollen proportions sum up to ca. $85 \%$. This high value is primarily reflected by subpáramo taxa with ca. $45 \%$. The pollen record at Laguna Cocha Caranga reflects stable conditions with ca. 25-30\% of páramo pollen taxa and $60 \%$ of pollen of subpáramo, UMF and LMF. Even if for the Laguna Rabadilla de Vaca site variations in pollen proportions are the most obvious between mid- and late Holocene times, changes are still relatively small. Proportions of páramo pollen slightly increase to 50-55\% and subpáramo, UMF and LMF pollen taxa show values of ca. 40\%. Data of both records from Cerro Toledo reveal similar proportions. Páramo pollen taxa are reflected by ca. $60 \%$ and pollen of subpáramo, UMF and LMF reaches ca. 30\%. 
Present

Pollen representation of present conditions, reflected in the uppermost samples of the records, is only slightly different to late Holocene times. The El Tiro record represents comparable pollen proportions to that of the late Holocene. Data from Laguna Cocha Caranga show a slight decrease in páramo pollen taxa to ca. $15 \%$ and an increase in subpáramo, UMF and LMF taxa to ca. $70 \%$, while this increase is mainly due to higher values of subpáramo pollen. At Laguna Rabadilla de Vaca, pollen proportions of subpáramo, UMF and LMF are slightly higher with almost $45 \%$, mainly because of increased subpáramo pollen percentages. Pollen data of the higher located Cerro Toledo site (CT record) are not considered because of sediment disturbance. At the lower site (CTB record), pollen proportions show a slight decrease in páramo pollen taxa to $50 \%$ and a complementary increase in subpáramo, UMF and LMF pollen proportions to ca. $45 \%$.

\subsection{Environmental reconstruction and visualization}

The environmental reconstruction concentrates on altitudinal shifts of the UFL, including dynamics of forest and páramo expansion in the wider PNP area. Past UFL structures probably were as heterogeneous as today (Peters, 2009). Sharp borders, as well as gradual transitions and forest patches above the UFL may already have occurred in the past. We assume that present-day vegetation types have also occurred in the past, but that the distribution limits of these vegetation types have changed. Small-scale differences, as well as compositional changes within the vegetation types are described in the text, but cannot be illustrated in detail. This also applies to land use patterns. Reconstructed vegetation changes (Table 4.4) and UFL positions (Fig. 4.3) are illustrated for the different time slices to offer a visual model of past regional vegetation patterns (Fig. 4.4).

\section{$\operatorname{LGM}$ (ca. 20,000 cal yr BP)}

The high proportion of páramo taxa at El Tiro (65\%) and Cerro Toledo (80\%) and comparably low presence of AP (30\% and $12 \%$, respectively) indicate that páramo vegetation extensively covered the crest regions and dominated the landscape. At these sites, similar vegetation composition of grass páramo with relative high proportions of Plantago reflects cold and wet conditions during the LGM (Niemann and Behling, 2007; Brunschön and Behling, 2009). At Cerro Toledo, UMF composition shows high amounts of Alnus (Brunschön and Behling, 2009), which supports wet conditions during the LGM at that site. At El Tiro, high values of Weinmannia within the UMF is recorded at this time. The UFL is estimated to occur at its lowest position of ca. $2100 \mathrm{~m}$ a.s.l. at El Tiro and ca. $2800 \mathrm{~m}$ a.s.l. at Cerro Toledo (Fig. 4.4 g, Table 4.4). This stands for a lowered UFL of ca. $700 \mathrm{~m}$ at El Tiro and of ca. $250 \mathrm{~m}$ at Cerro Toledo compared to present-day settings. At El Tiro, pollen from trees associated with lower and warmer habitats of the LMF, e.g. Alchornea, Acalypha, Cecropia or palm trees (Arecaceae), was not observed during last glacial 
times (Niemann and Behling, 2007), whereas at Cerro Toledo few pollen grains of these taxa were already recorded at this time. Hence, a more extensive UFL lowering of ca. $700 \mathrm{~m}$ at El Tiro seems to be plausible.

As known from other sites in the tropical region of Latin America (Colinvaux et al., 1996a), LGM glacier extensions correlated with the UFL lowering. Results of the Rabadilla de Vaca sediment suggest that glaciers descended to elevations of ca. $3300 \mathrm{~m}$ a.s.l. or lower some time before 11,700 cal yr BP (Niemann and Behling, 2009), while the analysis of Cerro Toledo record indicates that possible LGM glaciations did not extend to elevation of $3150 \mathrm{~m}$ a.s.l. within the study area. Heine (2000) estimated lower moraine limits in the eastern Ecuadorian Andes at altitudes of ca. 3750-3500 $\mathrm{m}$ a.s.l. during the LGM, and argued that the range of 3900$3000 \mathrm{~m}$ a.s.l. given by Schubert and Clapperton (1990) is far too large. Cirque lakes are found in the central PNP at elevations of ca. $3200 \mathrm{~m}$ a.s.l. and studies in the eastern Cordillera near Loja suggested for the lowest limits of terminal moraines elevations of 2750-2800 m a.s.l. for the Andean depression region (Rozsypal, 2000). However, these moraines may reflect glacier advances prior to ca. 20,000 cal yr BP, since no dating is provided and the estimate coincides with glacier advances of the penultimate and early last glaciation, stated by Schubert and Clapperton (1990). Hence, we suggest that the lowermost limit of glaciers were at $3200 \mathrm{~m}$ a.s.l. during the LGM (Fig. 4.4 g, Table 4.4). According to Zech et al. (2008), glaciers in the humid tropical Andes are mainly temperature sensitive, but also may reflect precipitation changes or even both factors combined (Heine, 2000). Indications of cold and wet LGM conditions as suggested by the pollen data (e.g. Brunschön and Behling, 2009), lead to the assumption that low temperatures and high precipitation caused glacier advances in the study region. These factors are most likely also responsible for the wide distribution of humid páramo vegetation as well as for the lower UFL position at altitudinal distances of several hundred meters to the glaciers. At the highest altitudes, between the ice cap in the central part of the PNP and the páramo vegetation below, humid superpáramo (Sklenář and Balslev, 2007) may have expanded, but this vegetation type cannot be distinguished here from the páramo pollen assemblages.

In the central part of the PNP, at Laguna Rabadilla de Vaca, the UFL shift was most likely similar to the shift at Cerro Toledo. Here, páramo occurred below the glaciers probably to elevations of ca. $2850 \mathrm{~m}$ a.s.l. (Fig. 4.3). Further north, near Laguna Cocha Caranga, we expect comparable UFL shifts to those in the central and southern part (Fig. 4.3 , Fig. $4.4 \mathrm{~g}$ ). This is supported by the highest UFL position, already reached during the earliest Holocene at this site (Table 4.4). However, even though the Cocha Caranga record reflects primarily eastern escarpment conditions the location in a small depression on the western escarpment may restrict comparability between the records. 


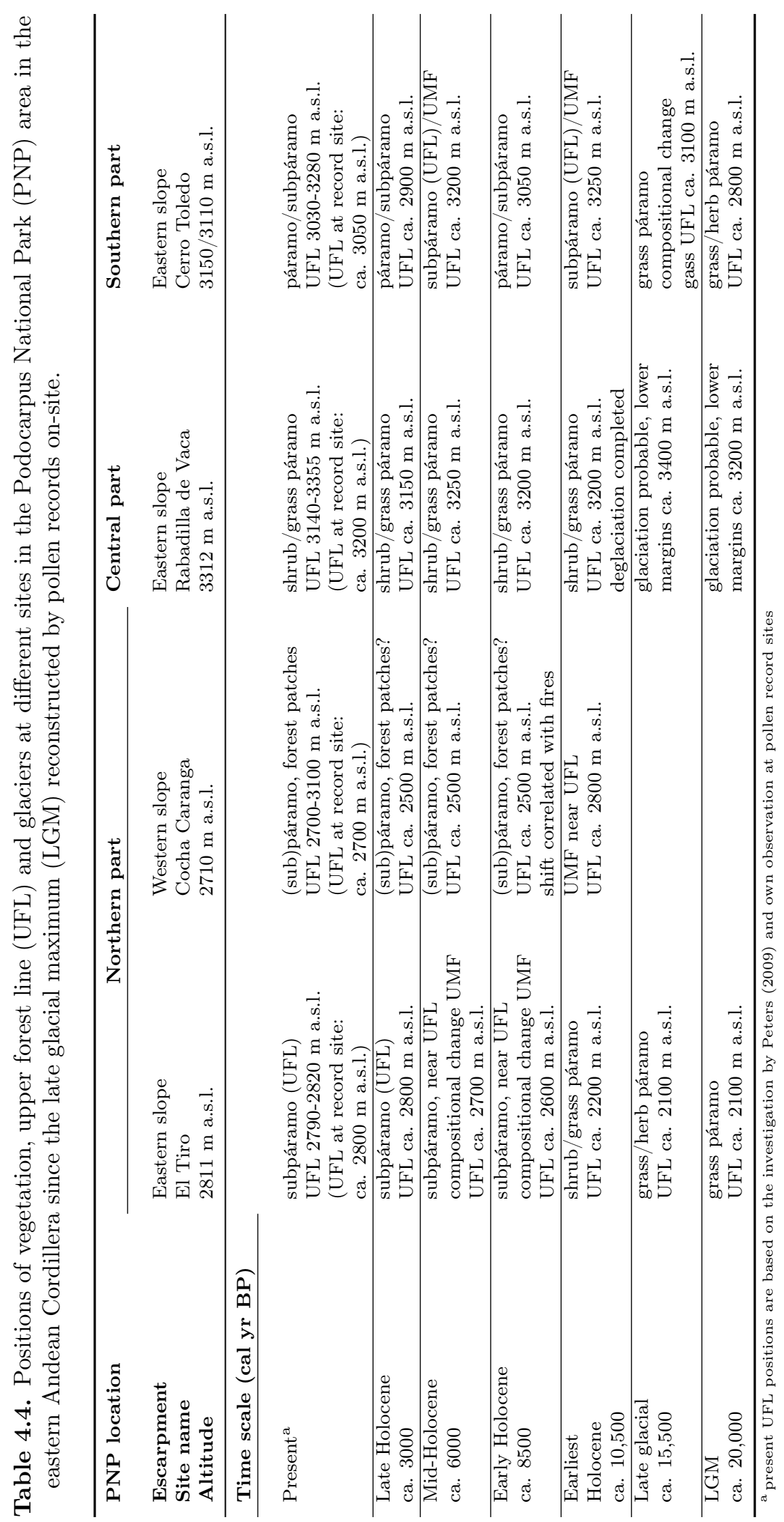


Late glacial (ca. 15,500 cal yr BP)

While the UFL position at El Tiro probably had not changed considerably during late glacial times, changes in the southern PNP are evident (Table 4.4). Increased AP proportions up to ca. 30\%, recorded for the Cerro Toledo site, were interpreted to indicate a UFL upslope shift of ca. $300 \mathrm{~m}$. This indicates for the late glacial a position of the UFL at ca. $3100 \mathrm{~m}$ a.s.l. in the southern PNP. Hence, páramo vegetation was restricted to higher elevations and compositional changes favoured the growth of Poaceae. Within the UMF, trees of Hedyosmum, Weinmannia and Podocarpaceae became more frequent (Brunschön and Behling, 2009). During this time, generally wet climatic conditions persisted, and thus we assume that primarily rising temperatures caused the forest expansion to higher elevations. Due to warmer conditions glaciers covering the central PNP area must have retreated concurrently. We estimate the lowest limits of terminal moraines at this time at ca. $3400 \mathrm{~m}$ a.s.l. (Fig. $4.4 \mathrm{f}$ ). The position of the UFL in the central part at Laguna Rabadilla de Vaca is estimated at altitudes ca. $300 \mathrm{~m}$ higher than before as this site is supposed to relate to Cerro Toledo. Conditions at Laguna Cocha Caranga were probably the same (Fig. 4.3), but due to the lack of palynological data, this assumption cannot be confirmed.

\section{During the earliest Holocene (ca. 10,500 cal yr BP)}

Within the whole PNP area, the UFL seems to have shifted upslope and we infer a temperature rise during earliest Holocene times. For all sites, the reconstructed upslope UFL shifts are in the range of ca. 100-150 m (Fig. 4.3). Accordingly, the UFL position at Cerro Toledo (3250 m a.s.l.) and Cocha Caranga (2800 m a.s.l.) may have been slightly higher than at present, whereas at El Tiro the UFL position was still low (2200 m a.s.l.). At Cerro Toledo, Alnus declined markedly (Brunschön and Behling, 2009) and was replaced by UMF taxa like Hedyosmum, Weinmannia and Podocarpaceae, which already became more frequent during the late glacial period. Pollen data of the Laguna Rabadilla de Vaca record (Fig. 4.2) indicate subpáramo vegetation close to páramo for elevations of ca. $3300 \mathrm{~m}$ a.s.l. and the UFL position probably was at ca. $3200 \mathrm{~m}$ a.s.l., as observed today. Because deglaciation most likely was completed, as already suggested by other studies at the same elevations (Bush et al., 2005), we expect that páramo covered the crest regions of the central PNP (Fig. $4.4 \mathrm{e}$ ).

\section{Early Holocene (ca. 8500 cal yr BP)}

During the early Holocene, the study area underwent different developments. While the forest and the UFL at El Tiro in the northern PNP area seem to have continued migrating upslope (almost 40\% more AP than before), at Laguna Cocha Caranga and Cerro Toledo downslope shifts of UFL positions are indicated (Fig. 4.3). Páramo vegetation probably re-expanded in areas of mid-elevation mountain ranges, whereas a constant distribution of páramo persisted in the highest and central part of the PNP. At the lowest mountain ranges near El Tiro, the UFL moved ca. $400 \mathrm{~m}$ upslope to 


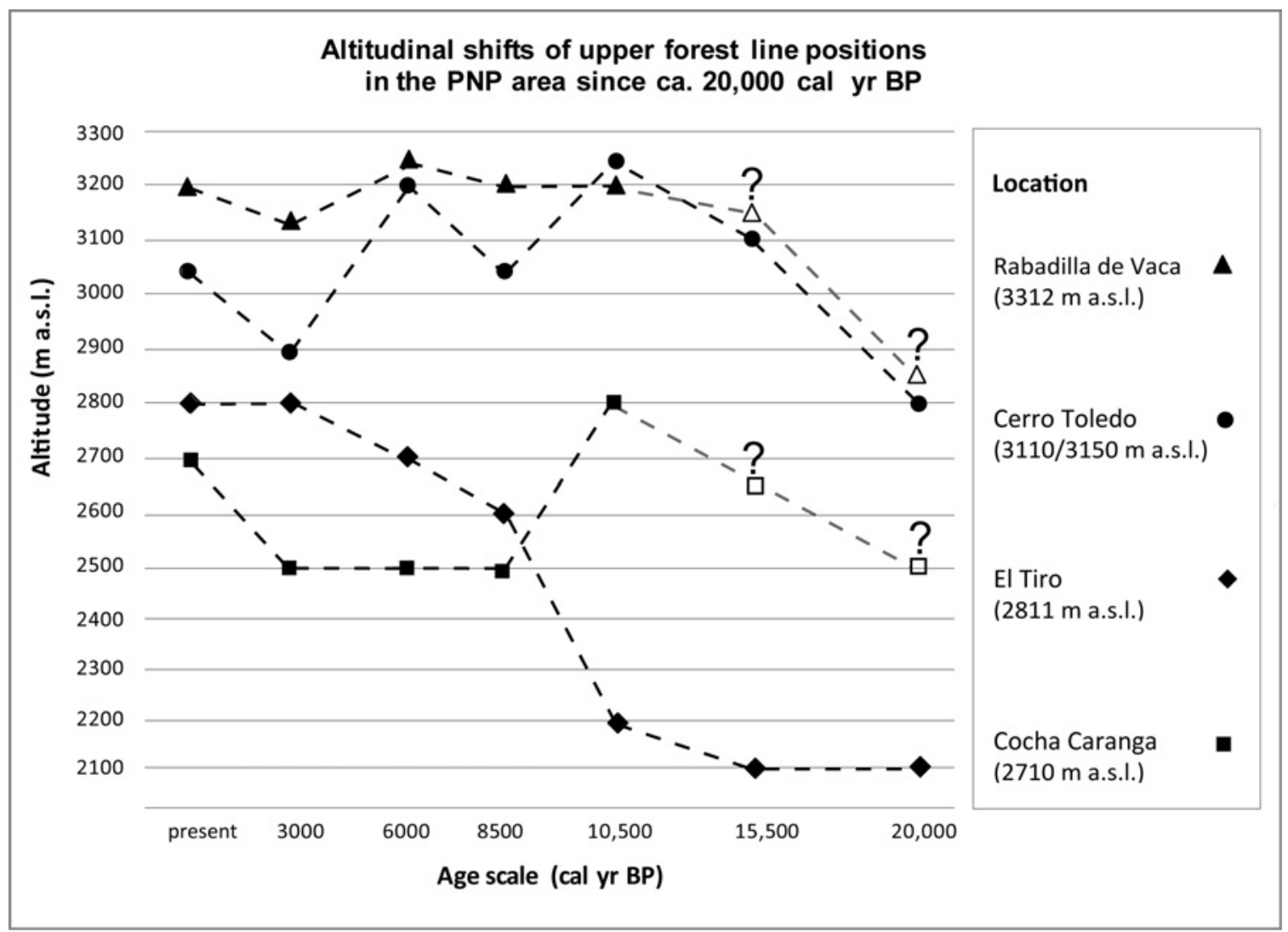

Figure 4.3. Altitudinal positions of the upper forest line since the last glacial maximum (ca. 20,000 cal yr BP) reconstructed for different sites in the Podocarpus National Park region. The locations of pollen records from north to south are: El Tiro, Laguna Cocha Caranga, Laguna Rabadilla de Vaca and Cerro Toledo (Fig. 4.1). Positions marked with a question mark have no local palynological evidence.

ca. $2600 \mathrm{~m}$ a.s.l, whereas at Laguna Cocha Caranga and Cerro Toledo the UFL was located ca. 200-300 m lower than before (ca. 20\% less AP) at elevations of 2500 and $3050 \mathrm{~m}$ a.s.l., respectively (Fig. $4.4 \mathrm{~d}$ ). We suggest that climate changes, which are spatially not uniform (Marchant et al., 2001) and can differ between different elevations (Wille et al. 2001), may have caused distinct developments. However, the suggested lower UFL at Laguna Cocha Caranga has to be interpreted in the context of local fires. Higher frequency of fires probably lowered the UFL position and particularly affected fire sensitive trees, e.g. of Weinmannia or Myrica (Niemann and Behling, 2009). The vegetation distribution at Rabadilla de Vaca, with a UFL position at ca. $3200 \mathrm{~m}$ a.s.l., remained stable. Data of Laguna Rabadilla de Vaca and Cocha Caranga indicate somewhat drier condition during this time (Niemann and Behling, 2009; Niemann et al., 2009), which may have favored fire occurrence at Cocha Caranga. Because generally humid conditions persisted in the PNP region, minor changes in precipitation probably did not influence forest growth. 

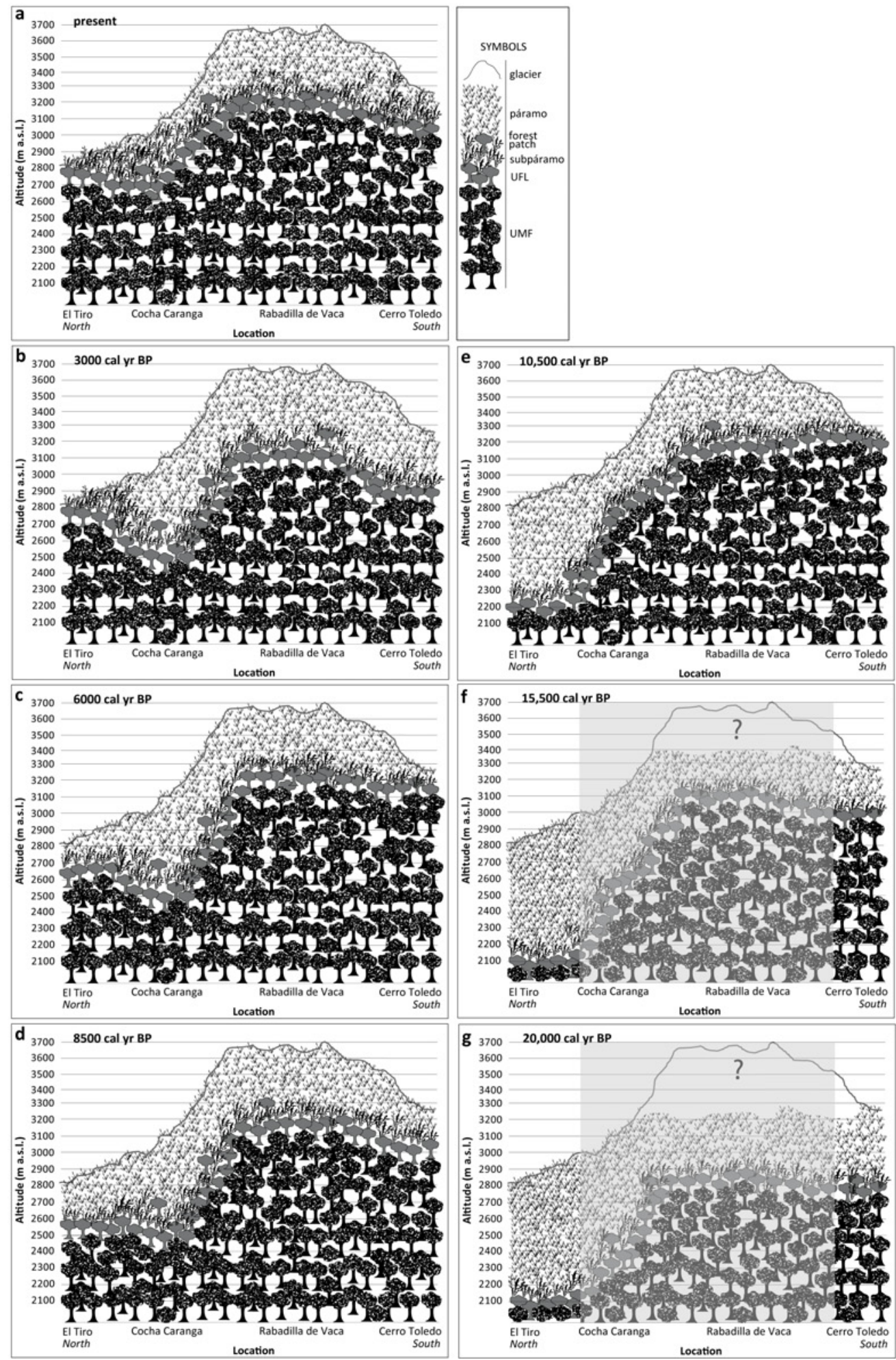

Figure 4.4. Visualization of (a) the present vegetation distribution for the reconstruction area in the Podocarpus National Park (PNP) and (b-g) past altitudinal positions of vegetation and UFL based on pollen data of the record sites at El Tiro, Laguna Cocha Caranga, Laguna Rabadilla de Vaca and Cerro Toledo. The visualization specifically illustrates overall vegetation patterns from the perspective of the eastern escarpment. Grey shaded parts in (f) and (g) display assumed conditions for the central PNP area based on the palynological evidence in the south and north. The occurrence and extension of glaciers are inferences (marked with a question mark) based on available studies on glaciations in the Ecuadorian Andes, which were matched with the pollen data. 


\section{Mid-Holocene (ca. 6000 cal yr BP)}

Similar conditions to those of the early Holocene are indicated for mid-Holocene times. At all sites the UFL was located slightly higher than before or stayed at the same elevation (Fig. 4.3, Table 4.4). UFL shifted upslope ca. 50-150 m (increase of AP to below 10\%). Most stable conditions are suggested for the central PNP, whereas e.g. successional changes of vegetation composition occurred at El Tiro. Between ca. 7000-4000 cal yr BP, variable climatic conditions caused changes in the composition of the UMF, favoring first Hedyosmum and later Myrsine, Ilex and Podocarpaceae (Niemann and Behling, 2007). During the mid-Holocene, the UFL probably reached slightly higher elevations than today in the southern and central PNP reaching elevations of ca. 3200 and $3250 \mathrm{~m}$ a.s.l. at Cerro Toledo and Laguna Rabadilla de Vaca, respectively. During this time, the UFL at Laguna Rabadilla de Vaca may have reached the highest position for the recorded sequence, whereas at Cerro Toledo a higher position of the UFL was already shown during the earliest Holocene. However, altitudinal differences only account for ca. $50 \mathrm{~m}$. In the northern part at El Tiro, positions of the UFL (ca. $2700 \mathrm{~m}$ a.s.l.) were still at slightly lower elevations compared to the present, while at Laguna Cocha Caranga the UFL remained at elevation of ca. $2500 \mathrm{~m}$ a.s.l. (Fig. $4.4 \mathrm{c}$ ). The latter was probably caused by fires, which favored the growth of Poaceae and repressed Weinmannia as primary tree genus within the UFL ecotone (Niemann and Behling, 2009).

\section{Late Holocene (ca. 3,000 cal yr BP)}

Conditions during the late Holocene approximated present-day settings (Fig. $4.4 \mathrm{~b}$ ). At El Tiro, the UFL shifted ca. $100 \mathrm{~m}$ upslope to the highest elevations of ca. $2800 \mathrm{~m}$ a.s.l., and the currently observed subpáramo belt developed already during this time (Table 4.4). This is indicated by the high AP proportion of ca. 85\%, of which ca. $45 \%$ are represented by subpáramo pollen taxa (Fig. 4.2). Conditions at Laguna Cocha Caranga have basically remained the same, while in the central and southern part, the UFL shifted down slope by ca. 100-300 m (Fig. 4.3). This is suggested by the expansion of Poaceae and by a decrease in AP taxa of ca. 10-30\%. The UFL positions were reconstructed at ca. $3150 \mathrm{~m}$ a.s.l. for the Laguna Rabadilla de Vaca site, and at ca. $2900 \mathrm{~m}$ a.s.l. for the Cerro Toledo area. The climatic variability may be one reason for these different changes. However, also human impacts may have played a role, as shown by the Laguna Rabadilla de Vaca record (Niemann et al., 2009). Archaeological studies dated the first human activities in the Loja region to ca. 4000 cal yr BP (Guffroy, 2004). Furthermore, the El Tiro record shows highest fire frequency after 3300 cal yr BP (Niemann and Behling, 2007). Hence, early human activities, e.g. wood extraction, land use by slash and burn and hunting (Niemann and Behling, 2007), may have resulted in páramo expansion and forest destruction.

Present

Since the late Holocene the vegetation distribution and UFL position changed only little (Fig. 4.3. Table 4.4). In the northern PNP area at El Tiro no considerable 
changes were recorded, whereas at Laguna Cocha Caranga an upslope UFL shift into elevations of ca. $2700 \mathrm{~m}$ a.s.l. most likely happened because of less human disturbance. This is supported by lowered fire frequency during the last 600-1000 years at Laguna Cocha Caranga as well as at El Tiro (Niemann and Behling, 2007, 2009). At Laguna Cocha Caranga, shrubs and trees of Melastomataceae expanded, which may also have resulted in UFL upslope shifts, as this family is dominant in mountain forests and subpáramo of the study region. However, this site still shows disturbances due to fires and human land conversion. The natural UFL could be ca. $100 \mathrm{~m}$ higher (Homeier et al., 2008). During the whole time sequence, most stable conditions were shown for the central PNP part. A slight UFL upslope shift, compared to ca. 3000 years before, represents basically subpáramo vegetation in the area that was more extensive and at higher elevation ( $5 \%$ of subpáramo pollen taxa increase). At Cerro Toledo, the páramo vegetation seems to have been slightly depressed since late Holocene times and the UFL shifted upslope to present positions at ca. $3050 \mathrm{~m}$ a.s.l. (Fig. 4.4 a). Reasons for this may be more severe human impact during the late Holocene than today.

\subsection{Discussion}

Given the still limited knowledge of the relationship between modern pollen rain and present-day vegetation for the northern Andes (Grabandt, 1980; Hansen and Rodbell, 1995; Hansen et al., 1984; Hooghiemstra, 1984; Melief, 1985; Rangel Ch., 2005 a/b; Van't Veer and Hooghiemstra, 2000; Weng et al., 2004) including Ecuador (Bakker et al., 2008; Bush et al., 1990, 2001; Colinvaux, 1987; Hansen et al., 2003; Moscol Olivera et al., 2009; Wille et al., 2002) and especially our study area (Niemann et al., 2010) and the widely discussed difficulties in estimating UFL shifts based on pollen data (e.g. Di Pasquale et al., 2008), our back-of-the-envelope calculation of UFL shifts provide a rough estimate, but does not claim precise altitudinal distribution of past vegetation. This and the limitations of the chronologic control have to be taken into consideration for the interpretation and when comparing our data with other studies.

Climatic conditions vary considerably throughout the Andes, and especially the Andean depression region is characterized by local climatic conditions, influencing the vegetation structure and the UFL position (Peters, 2009). Hemispheric palaeoclimatic changes with their regional and local differences result in differences of vegetation changes. Comparison of palynological studies in South America revealed besides general similarities in palaeoecological changes many differences in timing and extent of vegetation changes in response to climate changes (e.g. Di Pasquale et al., 2008; Markgraf, 1989). Hence, we decided to restrict a regional comparison to close-by study sites in Colombia and Ecuador, located in the eastern Andes outside the Andean depression region and in lower elevations of the western Ecuadorian Amazonia (Table 4.5).

Former estimates of altitudinal UFL shifts in the northern Andes were suggested by other investigations carried out in Colombia (Hooghiemstra, 1984) and Ecuador 
(Bakker et al., 2008, Wille et al., 2002). In these studies, a $200 \mathrm{~m}$ upslope shift of the UFL related to an increase in AP of ca. 10\% was assumed. Compared to our calculation, the UFL shifts are estimated to be twice as high as in our area. However, we do not necessarily expect similar relationships, as in our study region the present UFL structure and position is considerably different from those outside the Andean depression. Although the high species richness of the UFL ecotone in our study area may cause less traceable changes in pollen records, we suggest that the vegetation response to climate changes is firstly more variable and secondly less drastic with regard to altitudinal shifts. Therefore, we suggest that our calculation based on data of the investigated location is more suitable for this study than estimates of other areas.

During the cold and wet LGM period (ca. 20,000 cal yr BP) the UFL in the PNP area was considerably lower compared to present times as it was also shown for other regions (Table 4.5). Studies in western Amazonia (Bush et al., 1990; Colinvaux et al., 1996b; 2000) and in the Colombian Andes (Marchant et al., 2009; van der Hammen and Hooghiemstra, 2003; Wille et al., 2001) showed during glacial times the occurrence of mountain taxa or even upper Andean forest at ca. 800-1500 m downslope compared to their actual distribution. The relative wide range of these estimations results in different lapse rates calculated for the LGM temperature depression. For the PNP area we assume a more conservative estimate for the UFL position during the LGM. In the northernmost part near El Tiro, the UFL position was probably ca. $700 \mathrm{~m}$ lower than today and farther south by ca. $250 \mathrm{~m}$. This implies that forest occurred up to ca. 2100-2800 m a.s.l. at certain distances (altitudinal range ca. 700-400 m) to lower margins of glaciers. Local differences in past UFL shifts between northern and southern sites in the PNP may be explained by site-specific climatic conditions and species composition, which is known to cause the differences at present (Peters, 2009). Additionally, mountain barriers that impede climatic influence from the Amazon basin seem to be less effective in the southern part of the PNP than in the northern part (Brunschön and Behling, 2009). Hence, the lesser amount of UFL shifts at southern sites, which are also closer to the Amazon basin, can be explained. However, considering that the UFL position inside the Andean depression region is currently about $1200 \mathrm{~m}$ lower than at other sites in the northern and central Andes (Peters, 2009), our reconstruction agrees with the existing estimates. The downslope shift of the UFL in the PNP area was probably not as extensive as in other regions in the northern Andes, but the depression of mountain taxa is comparable to results of other studies. As the Andean depression today is characterized by specific climatic conditions, it is conceivable that also past climate changes in this part of relatively low mountain ranges were different from those of other areas. The strong easterlies bringing humid air masses from the Amazonian basin to the crest regions of the relative low elevated mountains in our study area present a critical factor that would explain the persistent humid conditions for the recorded time period. This has to be considered as an important factor for differences between vegetation changes in the Andean depression and outside of this region, where temperature is a superior driver for vegetation changes.

In this context, factors explaining the relatively low UFL position in the study 
area are of interest. In the Andean depression region, the combination of permanent easterlies, high amounts of precipitation throughout the year and probably extreme incidents of radiation are supposed to be responsible for the low UFL position (Peters, 2009). For other regions, temperature is supposed to be the main factor determining the upper limit of forest growth. Therefore, past UFL changes, which are quantified by temperature lapse rates, may be not the same for all sites. In our study region, past temperature changes are not be the crucial factor governing the upper limit of forest growth. The interactions between climate and vegetation are more complex. The lower and species-rich UFL in the Andean depression region facilitates a high variety of taxa-specific reactions to climate changes. Here, less extensive vegetation shifts than assumed for the less diverse UFL, dominated by Polylepis, may be most likely. Even during the past, Polylepis was absent in the area of the PNP. This is probably caused by persistent wet conditions in the study region. However, a consistently species-rich UFL ecotone through time, causing competition and limited space for habitats, may also have played a role. Regarding species-rich vegetation, climate change would rather have resulted in compositional changes than in altitudinal shifts of vegetation belts. The same is expected for the area under predicted future climatic change (Peters, 2009). The fact that taxa rather respond individually, depending on their ecology and flexibility to adapt to climatic changes, instead of whole vegetation belt shifting, had already been supposed previously (Colinvaux et al., 1996b; Peters, 2009).

During late glacial times glaciers must have retreated covering only the central and highest part of the PNP. We expect that increasing temperatures led to a complete deglaciation of the area by the onset of the Holocene. During this time changes observed in all fossil pollen records show gradual upslope shifts of the UFL of some hundred meters. However, there are considerable local differences between sites in Colombia and in the Ecuadorian Andean depression region (Table 4.5). This is most likely due to the high heterogeneity of the Andean climates, and reflects the complexity to reconstruct vegetation changes for larger regions. For the Cerro Toledo site in our study area, slightly higher UFL positions than observed at present were already found during the earliest Holocene. In contrast, at other sites, the highest UFL positions were reached in the most recent times (El Tiro) or during the mid-Holocene at ca. 6000 cal yr BP (Laguna Rabadilla de Vaca). The UFL positions remained within 50-200 $\mathrm{m}$ above the present, which implies that forest patches above the UFL may be remnants of closed forests. Besides rising temperatures, we would rather expect drier conditions to permit upslope migration of the UFL in our study area, which would be possible by dampened trade-wind systems (Bendix et al., 2009). Drier periods are indicated between ca. 9000 and $7000 \mathrm{cal}$ yr BP by the Rabadilla de Vaca record and between ca. 4000-1500 cal yr BP by the record of Laguna Cocha Caranga (Niemann and Behling, 2009). These periods of drier climate are not necessarily synchronous with times of higher UFL positions. Thus, relatively drier climates possibly were not dry enough for a forest growth at higher elevations. We suppose that the persistent humid conditions in the area throughout the recorded time period was the reason that the UFL was never considerably higher than today. Results in northern Ecuador indicated that during the last ca. 6000-7000 years the UFL position was never much 
higher than 100-200 m compared to the present (Bakker et al., 2008; Di Pasquale et al., 2008), which agrees with the results of our study area (Table 4.5). In Colombia, the UFL was several hundred meters higher than present during the mid-Holocene due to an increase in temperature (Hooghiemstra and van der Hammen, 1993; Wille et al., 2001).

Throughout the Holocene until present times, fire occurrence is consistently related to vegetation changes and is most likely due to human activities (e.g. Bakker et al., 2008; Wille et al., 2002; Niemann and Behling, 2007, 2009; Brunschön and Behling, 2009). Fires may have caused the expansion of páramo and the downslope shift of UFL (Bakker et al., 2008), or affected forest growth at higher elevations (Di Pasquale et al., 2008). During early to late Holocene times, when fires were recorded frequently in the PNP area, the Laguna Cocha Caranga record showed a lowered but relatively stable UFL position, whereas at El Tiro the UFL continued at a higher position (Niemann and Behling, 2007, 2009). Disturbances of vegetation by fires varied between sites and may have affected different taxa. The diverse and locally different UFL in our study region respond in different ways to fires, which may have caused compositional changes rather than extensive forest destruction. The amount of forest repression and páramo expansion due to fires was relatively minor, but we point out that individual and taxon-specific migrations and reactions to climatic changes or disturbances may be more extensive than reconstructed for the UFL ecotone. 


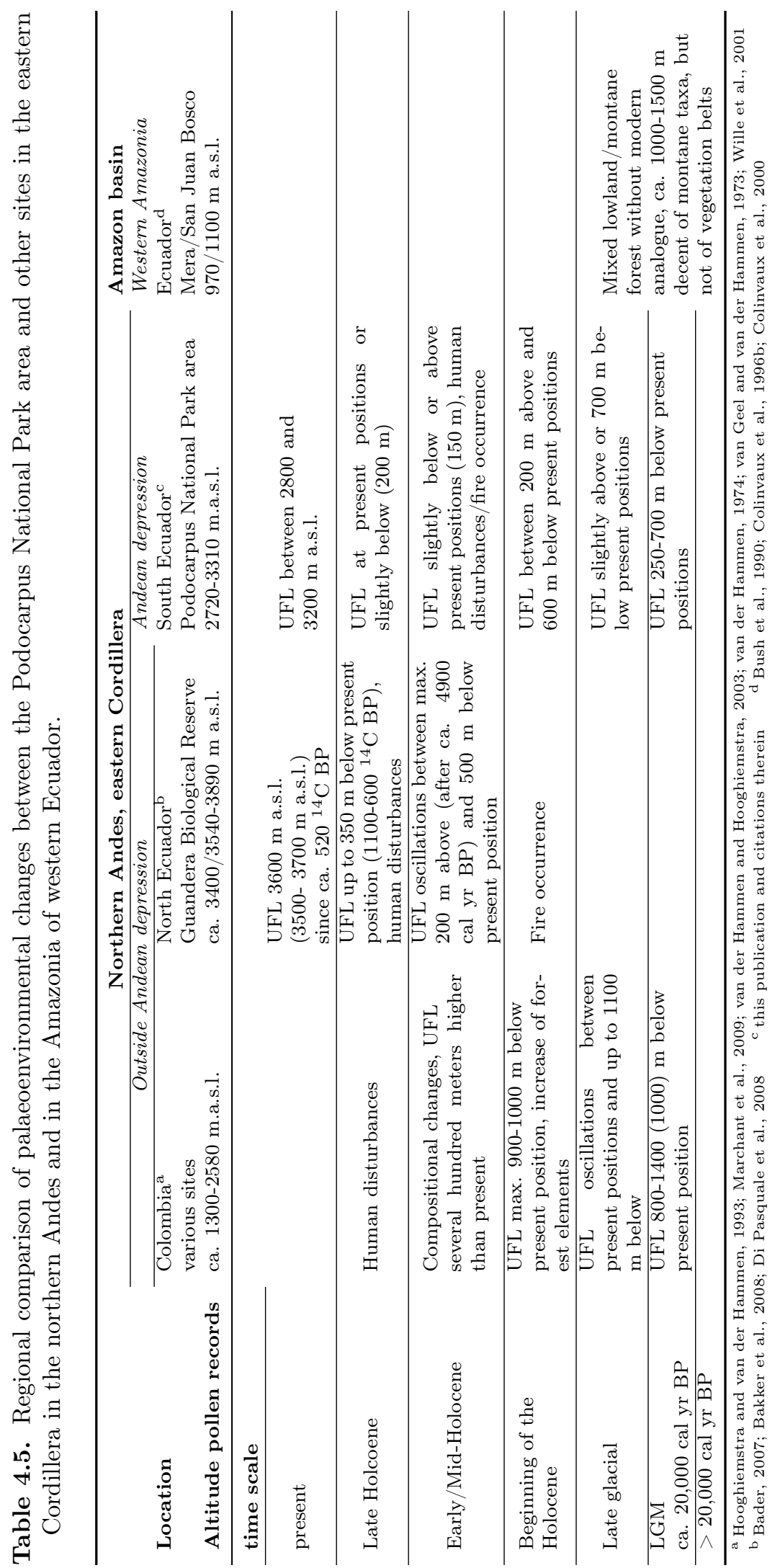




\subsection{Conclusions}

Based on our data it was shown that páramo vegetation widely dominated the landscape of the PNP area during the LGM and the UFL position was at least ca. $700 \mathrm{~m}$ lower in the northern part and ca. $250 \mathrm{~m}$ lower in the central and southern part, where climate influences of the eastern Amazon basin are greater. Already in late glacial times mountain forest developed and UFL shifted upslope in the southern and probably also the central part of the PNP, whereas the UFL did not shift usplope in the northernmost part near El Tiro until the onset of the Holocene. Hence, the UFL changes varied considerably in time and extend between the locations.

During the earliest Holocene to mid-Holocene times forests occurred ca. 50-200 m higher for the central and southern PNP, whereas in the northernmost part forest probably never reached elevation higher than today. Thus, forest patches found ca. $200 \mathrm{~m}$ above the actual UFL or higher may never have been connected to closed forest. Forest destruction caused by fires, most likely of anthropogenic origin, is indicated from early Holocene times on. Frequency of fires and vegetation response to it varied between sites, resulting in site-specific vegetation development. The spacial extend of forest destruction in its spatial dimension was relatively small, but certain taxa, e.g. Weinmannia or Myrica, were seriously affected by fires. The relatively low UFL position of the PNP area at that time may be rather natural than of anthropogenic origin.

There are considerable regional and local differences between past vegetation changes in the northern Andes. Due to the highly heterogeneous environments of the Andes, reflecting climatic and non-climatic conditions, differences in vegetation patterns exist as much today as they have apparently existed in the past. Many factors, e.g. temperature, precipitation, wind regimes, radiation and geomorphological conditions, are supposed to be responsible for the present-day vegetation patterns and the UFL position, but varied site-specific differences and interactions of these factors may be one reason for the observed heterogeneity. In the PNP area and the Andean depression region temperature seems to be less important than known for other regions of the northern Andes. Instead e.g. precipitation and wind may be much more important for the vegetation changes in our study region. Additionally, the highly species-rich UFL in the central Andean depression causes enhanced variety in vegetation response and may be less extensive shifts of forests compared to less diverse UFL in other Andean regions. This clearly demonstrates that vegetation patterns are highly variable, and results from one site should not be transferred to other sites without taking local conditions into consideration. This circumstance is especially important for nature conservation strategies and management planning. Natural or original positions of the UFL, which vary significantly between locations and show relative low altitudes in the Andean depression region, should be conserved.

The interpretation and vegetation reconstruction on a regional scale cannot describe the complete heterogeneity of the study area, but can attempt to specify overall environmental changes on a larger scale. Especially the visualization contributes to an enhanced regional understanding of vegetation dynamics in the study area. However, additional pollen records from lower elevations and undisturbed sites, as well as 
better estimates of UFL shifts based on pollen records or even macrofossil analysis, are required to verify the results and to improve the environmental reconstruction of the PNP area.

\subsection{Acknowledgements}

We thank the Deutsche Forschungsgemeinschaft (DFG) for financial support of the research group FOR 816 (Be 2116/8-1). We acknowledge the logistic support, which was kindly provided during field work by the FOR 816 staff in Ecuador. Holger Niemann is thanked for the provision of pollen data, which allowed the implementation of this study. And we also sincerely thank Thomas Giesecke for fruitful scientific discussions. 


\subsection{References}

Aguirre, Z., Cabrera, O., Sanchez, A., Merino, B., Maza, B., 2003. Composición floristica, endemismo y etnobotanica de la vegetación del Sector Oriental, parte baja del Parque Nacional Podocarpus. Lyonia 3, 5-14.

Bader, M.Y., 2007. Tropical alpine treelines - how ecological processes control vegetation patterning and dynamics. Dissertation, University of Wageningen, Netherlands, $193 \mathrm{pp}$.

Bakker, J., Moscol Olivera, M., Hooghiemstra, H., 2008. Holocene environmental change at the upper forest line in northern Ecuador. The Holocene 18, 1-17.

Barthlott, W., Mutke, J., Rafiqpoor, D., Kier, G., Kreft, H., 2005. Global centers of vascular plant diversity. Nova Acta Leopoldina 92, 61-83.

Beck, E., Richter, M., 2008. Ecological aspects of a biodiversity hotspot in the Andes of southern Ecuador. Biodiversity and Ecology Series 2, 195-217.

Beck, E., Bendix, J., Kottke, I., Makeschin, F., Mosandl, R. (Eds.), 2008a. Gradients in a Tropical Mountain Ecosystem of Ecuador. Ecological Studies 198. Springer, Berlin, Heidelberg, 525 pp.

Beck, E., Makeschin, F., Haubrich, F., Richter, M., Bendix, J., Valerezo, C., 2008b. The Ecosystem (Reserva Biológica San Francisco). In: Beck, E., Bendix, J., Kottke, I., Makeschin, F., Mosandl, R. (Eds.), Gradients in a tropical mountain ecosystem of Ecuador. Ecological Studies vol. 198, Springer, Berlin, Heidelberg, pp. 1-13.

Beck, E., Kottke, I., Bendix, J., Makeschin, F., Mosandl, R., 2008c. Gradients in a tropical mountain ecosystem - a synthesis. In: Beck, E., Bendix, J., Kottke, I., Makeschin, F., Mosandl, R. (Eds.), Gradients in a Tropical Mountain Ecosystem of Ecuador. Ecological Studies vol. 198, Springer, Berlin, Heidelberg, pp. 451-463.

Behling, H., 1993. Untersuchungen zur spätpleistozänen und holozänen Vegetationsund Klimageschichte der tropischen Küstenwälder und der Araukarienwälder in Santa Catarina (Südbrasilien). Dissertationes Botanicae 206, Cramer, Berlin, Stuttgart, 149 pp.

Bendix, J., Behling, H., Peters, T., Richter, M., Beck, E., 2009. Functional biodiversity and climate change along an altitudinal gradient in a tropical mountain rainforest. In: Tscharntke, T., Leuschner, C., Veldkamp, E., Faust, H. (Eds.), Tropical rainforests and agroforests und global change. Springer, Berlin.

Bendix, J., Rollenbeck, R., Richter, M., Fabian, P., Emck, P., 2008a. Climate. In: Beck, E., Bendix, J., Kottke, I., Makeschin, F., Mosandl, R. (Eds.), Gradients in a Tropical Mountain Ecosystem of Ecuador. Ecological Studies vol. 198, Springer, Berlin, Heidelberg, pp. 63-73. 
Bendix, J., Rollenbeck, R., Fabian, P., Emck, P., Richter, M., Beck, E., 2008b. Climate variability. In: Beck, E., Bendix, J., Kottke, I., Makeschin, F., Mosandl, R. (Eds.), Gradients in a Tropical Mountain Ecosystem of Ecuador. Ecological Studies vol. 198, Springer, Berlin, Heidelberg, pp. 281-290.

Brunschön, C., Behling, H., 2009. Late Quaternary vegetation, fire and climate history reconstructed from two cores at Cerro Toledo, Podocarpus National Park, southeastern Ecuadorian Andes. Quaternary Research 72, 388-399.

Brunschön, C., Haberzettl, T., Behling, H., 2010. High-resolution studies on vegetation succession, hydrological variations, anthropogenic impact and genesis of a subrecent lake in southern Ecuador. Vegetation History and Archaeobotany $19,191-206$.

Bush, M.B., Colinvaux, P.A., Wiemann, M.C., Piperno, D.R., Liu, K.-B., 1990. Late Pleistocene Temperature Depression and Vegetation Change in Ecuadorian Amazonia. Quaternary Research 34, 330-345.

Bush, M., Moreno, E., De Oliveira, P.E., Asanza, E., Colinvaux, P.A., 2001. The influence of biogeographic and ecological heterogeneity on Amazonian pollen spectra. Journal of Tropical Ecology 17, 729-743.

Bush, M.B., Hansen, B.C.S., Rodbell, D.T., Seltzer, G.O., Young, K.R., Leon, B., Abbott,M.B., Silman, M.R. and Gosling, W.D., 2005. A 17 000-year history of Andean climate and vegetation change from Laguna de Chochos, Peru. Journal of Quaternary Science 20, 703-14.

Bush, M.B., Hanselman, J.A., Hooghiemstra, H., 2007. Andean montane forests and climate change. In: Bush, M.B., Flenley, J.R. (Eds.), Tropical rainforest responses to climatic change. Springer, Praxis, pp. 33-54.

Bussmann, R.W., 2001. The montane forests of Reserva Biologica San Francisco (Zamora-Chinchipe, Ecuador). Vegetation zonation and natural regeneration. Erde 132, 9-25.

Bussmann, R.W., 2005. Bosques andinos del sur de Ecuador, clasificación, regeneración y uso. Revistas Peruviana Biologica 12, 203-216.

Colinvaux, P.A., 1987. Amazon diversity in light of the palaeoecological record. Quaternary Science Reviews 6, 93-114.

Colinvaux, P.A., Liu, K.-B., De Oliveira, P., Bush, M.B., Miller, M.C., SteinitzKannan, M., 1996a. Temperature depression in the lowland tropics in glacial times. Climatic Change 32, 19-33.

Colinvaux, P.A., de Oliveira, P.E., Moreno, J.E., Miller, M.C., Bush, M.B., 1996b. A long pollen record from Lowland Amazonia: forest and cooling in Glacial Times. Science 274, 85-88. 
Colinvaux, P.A., De Oliveira, P.E., Bush, M.B., 2000. Amazonian and neotropical plant communities on glacial time-scales: The failure of the aridity and refuge hypotheses. Quaternary Science Reviews 19, 141-169.

Di Pasquale, G., Marziano, M., Impagliazzo, S., Lubritto, C., De Natale, A., Bader, M.Y., 2008. The Holocene treeline in the northern Andes (Ecuador): First evidence from soil charcoal. Palaeogeography, Palaeoclimatology, Palaeoecology $259,17-34$.

Emck, P., 2007. A Climatology of South Ecuador - With Special Focus on the Major Andean Ridge as Atlantic-Pacific climate Divide. Dissertation, Universität Erlangen-Nürnberg, Germany, 275 pp.

Fægri, K., Iversen, J., 1989. Textbook of pollen analysis, 4th edn., Wiley, Chichester.

Gentry, A.H., 1995. Patterns of diversity and floristic composition in neotropical montane forests. In: Churchill, S.P., Balslev, H., Forero, E., Luteyn, J.L. (Eds.), Biodiversity and conservation of Neotropical montane forests. New York Botanical Garden, pp. 103-26.

Gosling, W.D., Bunting, M.J., 2008. A role for palaeoecology in anticipating future change in mountain regions? Palaeogeography, Palaeoclimatology, Palaeoecology $259,1-5$.

Grabandt, R.A.J., 1980. Pollen rain in relation to arboreal vegetation in the Colombian Cordillera Oriental. Review of Palaeobotany and Palynology 29, 65-82.

Grimm, E.C., 2004. Tilia graph v. 2.0.2. Illinois State Museum, Research and Collections Center.

Guffroy J., 2004. Catamayo precolombino: Investigaciones arqueologicas en la provincia de Loja (Ecuador). IRD editions, Paris.

Hansen, B.C.S., Rodbell, D.T., 1995. A Late-Glacial/Holocene pollen record from the eastern Andes of northern Peru. Quaternary Research 44, 216-227.

Hansen, B.C.S., Wright, H.E., Bradbury, J.P., 1984. Pollen studies in the Junín area, central Peruvian Andes. Geological Society of America Bulletin 95, 1454-1465.

Hansen, B.C.S., Rodbell, D.T., Seltzer, G.O., León, B., Young, K.R., Abbott, M., 2003. Late-glacial and Holocene vegetational history from two sites in the western Cordillera of southwestern Ecuador. Palaeogeography, Palaeoclimatology, Palaeoecology 194, 79-108.

Heine, K., 1995. Bedded Slope deposits with respect to the Late Quaternary Glacial Sequence in the High Andes of Ecuador and Bolivia. In: Slaymaker, O. (Ed.), Steepland Geomorphology. Wiley, New York, pp. 257-278. 
Heine, K., 1996. The extent of the last glaciation in the Bolivian Andes (Cordillera Real) and paleoclimatic implications. Zeitschrift für Geomorpholgie N.F., Suppl. Bd. 104, 187-202.

Heine, K., 2000. Tropical South America during the Last Glacial Maximum: evidence from glacial, periglacial and fluvial records. Quaternary International 72, 7-21.

Henderson, A., Churchill, S.P., Luteyn, J., 1991. Neotropical plant diversity. Nature $351,21-22$.

Homeier, J., Werner, F.A., 2007. Preliminary checklist of the spermatophytes of the Reserva San Francisco (Prov. Zamora-Chinchipe, Ecuador). In: LiedeSchumann, S., Breckle, S.W. (Eds.), Provisional Checklists of Flora and Fauna of the San Francisco valley and its surroundings (Estación Científica San Francisco), Southern Ecuador. Ecotropical Monographs 4, 15-58.

Homeier, J., Werner, F.A., Gradstein, S.R., Breckle, S.-W., Richter, M., 2008. Potential vegetation and floristic composition of Andean forests in South Ecuador, with a focus on the RBSF. In: Beck, E., Bendix, J., Kottke, I., Makeschin, F., Mosandl, R. (Eds.), Gradients in a Tropical Mountain Ecosystem of Ecuador. Ecological Studies vol. 198, Springer, Berlin, Heidelberg, pp. 87-100.

Hooghiemstra, H., 1984. Vegetation and climatic history of the High Plain of Bogota, Colombia: a continuous record of the last 3,5 million years. Dissertationes Botanicae 79, Cramer, Vaduz, 368 pp.

Hooghiemstra, H., van der Hammen, T., 1993. Late Quaternary vegetation history and Laguna Pedro Palo (subandean forest belt, Colombia). Review of Palaeobotany and Palynology 17, 235-262.

Kessler, M., 1995. Polylepis-Wälder Boliviens: Taxa, Ökologie, Verbreitung und Geschichte. Dissertationes Botanicae 246, Berlin, Stuttgart, 303 pp.

Lozano, P.E., 2002. Los tipos de bosque en el sur de Ecuador. In: Aguirre, Z., Madsen, J.E., Cotton, E., Balsev, H., (Eds.), Bótanica Austroecuatoriana. Estudios sobre los recursos vegetales en las provincial de El Oro, Loja y ZamoraChinchipe. Abya-Yala, Quito, pp. 29-49.

Lozano, P., Delgado, T., Aguirre, Z., 2003. Estado actual de la flora endemica exclusive y su distribucion en el Occidente del Parque Nacional Podocarpus. Funbotanica y Herbario y Jardin Botanico. Loja, Ecuador.

Marchant, R., Behling, H., Berrio, J.C., Cleef, A., Duivenvoorden, J., Hooghiemstra, H., Kuhry, P., Melief, B., van Geel, B., van der Hammen, T., van Reenen, G., Wille, M., 2001. Mid- to Late-Holocene pollen-based biome reconstructions for Colombia. Quaternary Science Reviews 20, 1289-1308. 
Marchant, R., Harrison, S.P., Hooghiemstra, H., Markgraf, V., van Boxel, J. H., Ager, T., Almeida, L., Anderson, R., Baied, C., Behling, H., Berrio, J.C., Burbridge, R., Björck, S., Byrne, R., Bush, M.B., Cleef, A.M., Duivenvoorden, J.F., Flenley, J.R., De Oliveira, P., van Geel, B., Graf, K.J., Gosling, W.D., Harbele, S., van der Hammen, T., Hansen, B.C.S., Horn, S.P., Islebe, G.A., Kuhry, P., Ledru, M.-P., Mayle, F.E., Leyden, B.W., Lozano-García, S., Melief, A.B.M, Moreno, P., Moar, N.T., Prieto, A., van Reenen, G.B., Salgado-Labouriau, M.L., Schäbitz, F., Schreve-Brinkman, E.J., Wille, M., 2009. Pollen-based biome reconstructions for Latin America at 0, 6000 and 18000 radiocarbon years. Climate of the Past Discussions 5, 369-461.

Markgraf, V., 1989. Palaeoclimates in Central and South America since 18,000 BP based on pollen and lake-level records. Quaternary Science Reviews 8, 1-24.

Matthias, I., 2008. Rekonstruktion der Umwelt- und Siedlungsgeschichte von Loja durch Multiproxy-Analysen an limnischen Sedimenten der Laguna Daniel Alvarez in Südecuador. Diplomarbeit, Universität Göttingen, Germany (unpublished).

McCormac, F.G., Hogg, A.G., Blackwell, P.G., Buck, C.E., Higham, T.F.G., Reimer, P.J., 2004. SHCal04 Southern Hemisphere Calibration 0-11.0 cal Kyr BP. Radiocarbon 46, 1087-1092.

Melief, A.B.M., 1985. Late Quaternary Paleoecology of the Parque Nacional Natural los Nevados (Cordillera Central), and Sumapaz (Cordillera Oriental) Areas, Colombia. Doctoral Thesis. University of Amsterdam, 162 pp.

Mosandl, R., Günter, S., Stimm, B., Weber, M., 2008. Ecuador Suffers the Highest Deforestation Rate in South America. In: Beck, E., Bendix, J., Kottke, I., Makeschin, F., Mosandl, R. (Eds.), Gradients in a Tropical Mountain Ecosystem of Ecuador. Ecological Studies vol. 198, Springer, Berlin, Heidelberg, pp. 37-40.

Moscol Olivera, M., Duivenvoorden, J.F., Hooghiemstra, H., 2009. Pollen rain and pollen representation across a forest-páramo ecotone in northern Ecuador. Review of Palaeobotany and Palynology 157, 285-300.

Niemann H., Behling H., 2007. Late Quaternary vegetation, climate and fire dynamics inferred from the El Tiro record in the southeastern Ecuadorian Andes. Journal of Quaternary Science 23, 203-212.

Niemann H., Behling, H., 2009. Late Pleistocene and Holocene environmental change inferred from the Cocha Caranga sediment and soil records in the southeastern Ecuadorian Andes. Palaeogeography, Palaeoclimatology, Palaeoecology 276, $1-14$.

Niemann, H., Behling, H., 2010. Late Holocene environmental change and human impact inferred from three soil monoliths and the Laguna Zurita multi-proxi record 
in the southeastern Ecuadorian Andes. Vegetation History and Archaeobotany $19,1-15$.

Niemann, H., Haberzettl, T., Behling, H., 2009. Holocene climate variability and vegetation dynamics inferred from the (11700 cal. yr BP) Laguna Rabadilla de Vaca sediment record, southeastern Ecuadorian Andes. The Holocene 19, 307-316.

Niemann, H., Brunschön, C., Behling, H., 2010. Vegetation/modern pollen rain relationship along an altitudinal transect between 1920 and $3185 \mathrm{~m}$ a.s.l. in the Podocarpus National Park region, southeastern Ecuadorian Andes. Review of Palaeobotany and Palynology 159, 69-80.

Peters, T., 2009. Struktur und ökologische Merkmale der oberen Waldgrenze in der Andinen Depression. Dissertation, Universität Erlangen-Nürnberg, Germany, $257 \mathrm{pp}$.

Rangel Ch., J.O., 2005a. Lluvia de polen en el páramo del Tatamá. In: van der Hammen, T., Rangel Ch., J.O., Cleef, A.M. (Eds.), La Cordillera Occidental Colombiana, Transecto Tatamá. Studies on Tropical Andean Ecosystems/Estudios de Ecosistemas Tropandinos 6 (ECOANDES 6). Cramer-Borntraeger, BerlinStuttgart, pp. 689-709.

Rangel Ch., J.O., 2005b. Lluvia de polen a lo largo de los transectos del macizo del Tatamá. In: van der Hammen, T., Rangel Ch., J.O., Cleef, A.M. (Eds.), La Cordillera Occidental Colombiana, Transecto Tatamá. Studies on Tropical Andean Ecosystems/Estudios de Ecosistemas Tropandinos 6 (ECOANDES 6). Cramer-Borntraeger, Berlin-Stuttgart, pp. 711-755.

Richter, M., 2003. Using epiphytes and soil temperature for ecoclimatic interpretations in south Ecuador. Erdkunde 57, 161-181.

Richter, M., 2008. Tropical mountain forests - distribution and general features. In: Gradstein, S.R., Homeier, J., Gansert, D. (Eds.), The Tropical Mountain Forest - Patterns and Processes in a Biodiverity Hotspot. Biodiversity and Ecology Series vol. 2, Universitätsverlag Göttingen, Göttingen, pp. 7-24.

Richter, M., Moreira-Muñoz, A., 2005. Climatic heterogeneity and plant diversity in southern Ecuador experienced by phytoindication. Review of Peruvian Biology $12,217-238$.

Richter, M., Diertl, K.-H., Peters, T., Bussmann, R.W., 2008. Vegetation Structures and Ecological Features of the Upper Timberline Ecotone. In: Beck, E., Bendix, J., Kottke, I., Makeschin, F., Mosandl, R. (Eds.), Gradients in a tropical mountain ecosystem of Ecuador. Ecological Studies vol. 198, Springer, Berlin, Heidelberg, pp. 275-280. 
Richter, M., Diertl. K.-H., Emck, P., Peters, T., Beck, E., 2009. Reasons for an outstanding plant diversity in the tropical Andes of Southern Ecuador. Landscape Online 12, 1-35.

Rodríguez, F., Behling, H., 2010. Late Holocene vegetation, fire, climate and upper forest line dynamics in the Podocarpus National Park, southeastern Ecuador. Vegetation History and Archaeobotany.

Rozsypal, A.A., 2000. Die pleistozäne Glazialmorphologie in Ecuador und Nordperu unter besonderer Betrachtung der Cordillera Oriental bei Loja. Diplomarbeit, Institut für Geographie, Universität Erlangen-Nürnberg (unpublished).

Schubert, C., Clapperton, C.M., 1990. Quaternary glaciations in the northern Andes (Venezuela, Colombia and Ecuador). Quaternary Science Reviews 9, 123-135.

Sklenár, P., Balslev, H., 2007. Geographic flora elements in the Ecuadorian superpáramo. Flora 202, 50-61.

Stuiver, M., Reimer, P.J., 1993. Extended 14C database and revised CALIB radiocarbon calibration program. Radiocarbon 35, 215-230.

Tinner,W., 2007. Treeline Studies. In: Elias, S.A. (Ed.), Encyclopedia of Quaternary Science, Elsevier, Amsterdam, pp. 2374-2384.

van der Hammen, T., 1974. The Pleistocene changes of vegetation and climate in tropical South America. Journal of Biogeography 1, 3-26.

van der Hammen, T., González, E., 1960: Upper Pleistocene and Holocene climate and vegetation of the 'Sabana de Bogota' (Colombia, South America). Leidse Geologische Mededelingen 25, 261-315.

van der Hammen, T., Hooghiemstra, H., 2003. Interglacial-glacial Fuquene-3 pollen record from Colombia: an Eemian to Holocene climate record. Global and Planetary Change 36, 181-199.

van Geel, B., van der Hammen, T., 1973. Upper Quaternary vegetational and climatic sequence of the Fuquene area (Eastern Cordillera, Colombia). Palaeogeography, Palaeoclimatology, Palaeoecology 14, 9-92.

Van 't Veer, R., Hooghiemstra, H., 2000. Montane forest evolution during the last 650,000 years in Colombia: a multivariate approach based on pollen record Funza-I. Journal of Quaternary Science 15, 329-346.

Weng, C., Bush, M., Silman, M.R., 2004. An analysis of modern pollen rain on an elevational gradient in southern Peru. Journal of Tropical Ecology 20, 113-124.

Weninger, B., Jöris, O., Danzeglocke, U., 2004. Calpal: The Cologne radiocarbon CALibration and PALaeoclimate research package. URL: http://www.calpal.de 
Wille, M., Hooghiemstra, H., Behling, H., van der Borg, K., Negret, A.J., 2001. Environmental change in the Colombian subandean forest belt from 8 pollen records: the last 50 kyr. Vegetation History and Archaebotany 10, 61-77.

Wille, M., Hooghiemstra, H., Hofstede, R., Fehse, J., Sevink, J., 2002. Upper forest line reconstruction in a deforested area in northern Ecuador based on pollen and vegetation analysis. Journal of Tropical Ecology 18, 409-440.

Zech, R., May, J.-H., Kull, C., Ilgner, J., Kubik, W., Veit, H., 2008. Timing of the late Quaternary glaciation in the Andes from 15 to $40^{\circ}$ S. Journal of Quaternary Science 23, 635-647. 


\section{Chapter 5.}

\section{Vegetation/modern pollen rain relationship along an altitudinal transect between 1920 and $3185 \mathrm{~m}$ a.s.l. in the Podocarpus National Park region, southeastern Ecuadorian Andes}

Niemann, H., Brunschön, C. and Behling, H.

Review of Palaeobotany and Palynology 159 (2010) 69-80

\subsection{Abstract}

To study vegetation/modern pollen rain relationship a total of 41 pollen traps have been installed for one year on an altitudinal transect between 1800 and $3185 \mathrm{~m}$ a.s.l. elevation in the montane forest and páramo vegetation type of the ECSF research area, located between Loja and Zamora in the southeastern Ecuadorian Andes. Results revealed that the altitudinal vegetation gradient of lower montane forest, upper montane forest, subpáramo and páramo is well reflected in the modern pollen rain data. Principal component analysis (PCA) on the pollen rain data indicate that a high number of pollen and spore taxa are characteristic for one vegetation type or reflect the altitudinal distribution of genera and families of modern vegetation. However, a considerable number of pollen and spore taxa not representing modern vegetation types were identified as well. Wind dispersal is supposed to be responsible for differences found between plant and pollen distribution patterns. Characteristic pollen and spore taxa for the lower montane forest are Alchornea, Heliocarpus and Hyeronima; for the upper montane forest Cyathea spp., Elaphoglossum ciliatum and Purdiaea nutans; and for the subpáramo Cyperaceae, Ericaceae, Jamesonia and Valeriana. The position of the modern upper timberline in the research area is reflected in the pollen rain by an increase of subpáramo taxa and a decrease of montane forest taxa.

Keywords: Ecuador, montane forest, páramo, modern pollen rain, upper timberline, principal component analysis (PCA), wind dispersal 


\subsection{Introduction}

The Ecuadorian Andes harbour one of the most species rich ecosystems on earth (Barthlott et al., 2005). Despite this high biodiversity, habitat loss is a concern for conservation efforts. Huge areas in this region have been strongly affected by humans during the past in particular during the last decades. Conservation of natural vegetation, and less degraded areas as well as sustainable management in areas under land use are urgently needed. To study the highly diverse montane forest and páramo ecosystems in southeastern Ecuador, extended research has been carried out in the framework of the "Deutsche Forschungsgemeinschaft" (DFG) research unit "Tropical Mountain Ecosystems" focusing on the Podocarpus National Park (Beck et al., 2008a).

Studies on modern vegetation and pollen rain provide important background information for the interpretation of fossil pollen records to reconstruct past vegetation changes. Recent studies on vegetation and climate history of the Podocarpus National Park region (Niemann and Behling, 2008; Niemann and Behling, 2009, 2010; Niemann et al., 2009; Brunschön and Behling, 2009) demand additional evidence of modern pollen rain data in relation to modern vegetation.

Few pollen rain studies are available from the northern Andes and western Amazonia (Fig. 5.1): The Sumapaz area, eastern Cordillera of Colombia between 1120 and $4250 \mathrm{~m}$ a.s.l. (Melief, 1985), the High Plain of Bogota (Colombia) between 2600 and $3800 \mathrm{~m}$ a.s.l. (Hooghiemstra and Cleef, 1984), the Mera site between 300 and 3400 m a.s.l.. in Ecuadorian Amazonia (Bush et al., 1990), the Cuyabeno Faunal Reserve in Ecuadorian Amazonia (Bush et al., 2001), Laguna Baja between 2800 and $3800 \mathrm{~m}$ a.s.l. in northern Peru (Hansen and Rodbell, 1995), Junin area between 900 and $4600 \mathrm{~m}$ a.s.l. in central Peru (Hansen et al., 1984) and Madre de Dios River between 340 and $3530 \mathrm{~m}$ a.s.l. in southeastern Peru (Weng et al., 2004). From the southern Ecuadorian Andes, within the so-called Andean depression region (see below), no studies on vegetation/pollen rain relationships are available so far. Therefore, this work is very important for improving the interpretation of the fossil pollen records from this region.

In this study we present modern pollen rain data from tropical Andean habitats to test the hypothesis that pollen rain data can be quantified statistically and we address the following main questions: How is the modern vegetation reflected in the modern pollen rain spectra and are there any key taxa of pollen and spores representing different vegetation types? Is it possible to distinguish between different vegetation types to identify the upper timberline position in the study area by modern pollen rain data? How do prevailing pollination systems influence the distribution pattern of modern pollen rain? And finally, what can we learn from modern pollen data for the interpretation of fossil pollen records? 


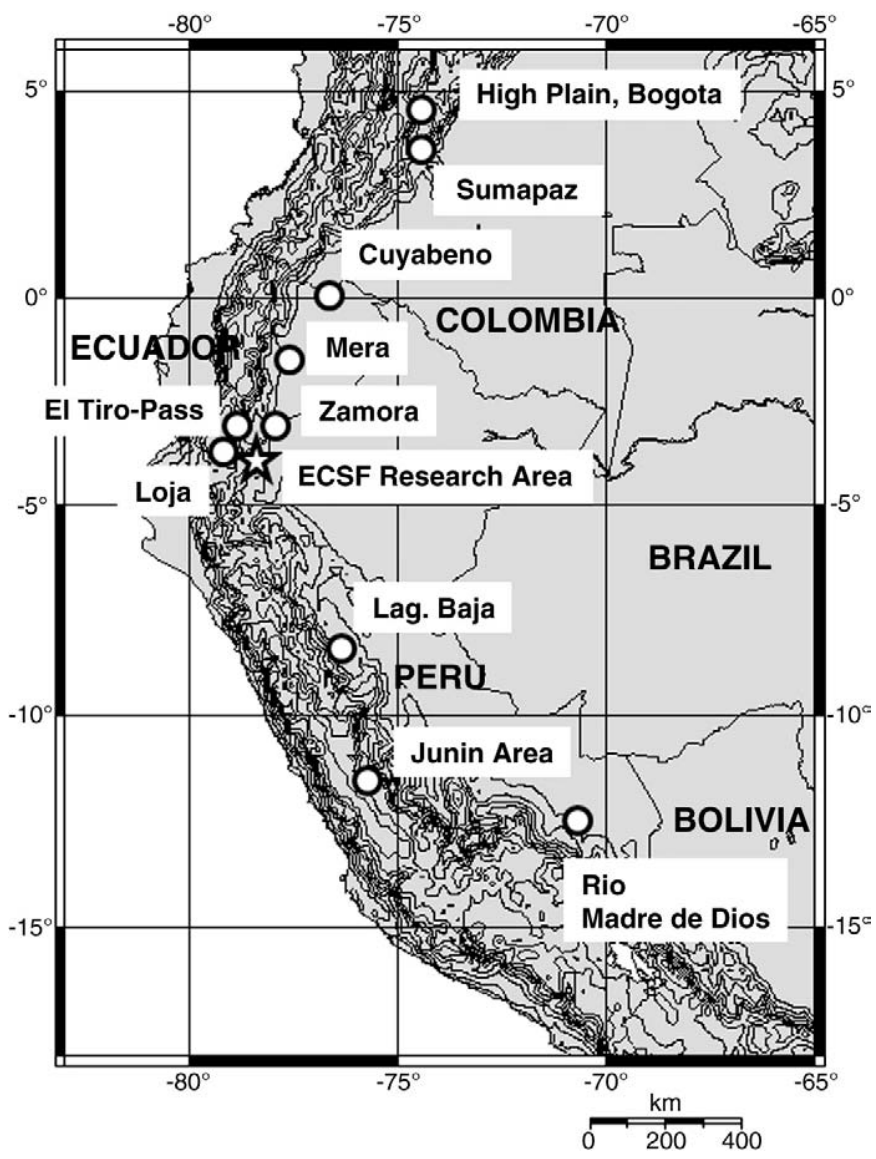

Figure 5.1. Map of northwestern tropical South America, showing the study site (star) and other locations of greater interest for this study (circles). OMC (www.aquarius.geomar.de).

\subsection{Site description}

\section{Location}

The Andes of southern Ecuador and northern Peru are part of the Andean depression region (Depression of Giron-Cuenca in Ecuador and of Huancabamba in Peru). The highest peaks of the mountains in this region reach up to about $4000 \mathrm{~m}$ a.s.l. Active volcanoes are absent (Richter and Moreira-Muñoz, 2005).

The study area is located within this Andean depression at the eastern escarpment of the eastern Cordillera (Cordillera Real) in the upper Rio San Francisco valley. The study was carried out in the northern part of the Podocarpus National Park inside the Estacion Cientifica San Francisco (ECSF) research area $\left(03^{\circ} 58^{\prime} 30^{\prime \prime} \mathrm{S}, 79^{\circ} 04^{\prime} 25^{\prime \prime} \mathrm{W}\right)$ between 1800 and $3185 \mathrm{~m}$ a.s.l. (Fig. 5.2). The studied mountain ridge is called Cerro del Consuelo. The ECSF area is adjacent to the main road between Loja (2200 $\mathrm{m}$ a.s.l.) in the inter-Andean valley and Zamora (1000 $\mathrm{m}$ a.s.l.) at the Amazonian flank. The whole area covers about 1100 ha along a ca. $5 \mathrm{~km}$ mountain ridge system orientated north-southwards (Fig. 5.2). 


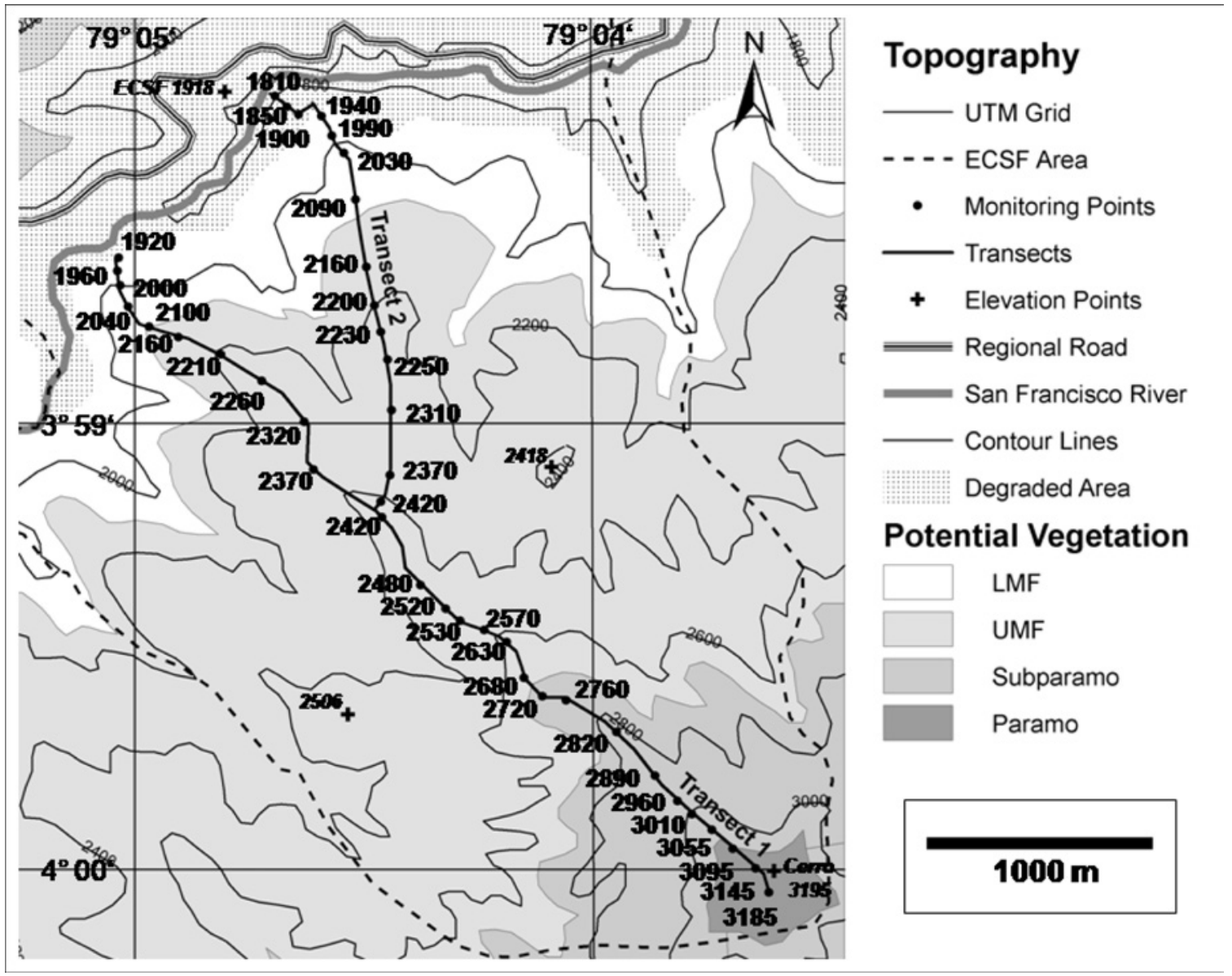

Figure 5.2. Map of the ECSF research area, showing the potential vegetation and the sampling sites of the modern pollen rain, including the elevation. Mapa Topográfico del Ecuador 1:50.000, Hoja Loja Sur 3781-I. 


\section{Climate}

The climate of Ecuador is dominated by the tropical trade wind regime, which is well established in the mid- and higher troposphere, with strong easterly winds throughout the year. The surface wind field is locally and regionally modified by the complex topography of the Andes and the thermal land-sea contrast at the Pacific coast. The southeastern part of the country, encompassing the ECSF research area, is mainly influenced by easterly winds. Westerly winds occur occasionally in austral summer. The main rainy season lasts from April to August, but rainfall is high throughout the whole year (Beck et al., 2008b). As part of the so-called Andean depression, all summits in the southern Ecuadorian Andes are below the snowline.

The Cordillera Real forms a division that separates the moist eastern Andean slopes facing the Amazon basin from the dry inter-Andean basins (e.g., the Lojaand Catamayo Basin). Between the eastern slopes of the Cordillera Real and the dry valley of Catamayo, which is less than $70 \mathrm{~km}$ apart, annual rainfalls drop from over 4000 to $300 \mathrm{~mm}$ (Bendix et al., 2004). Studies from Bendix et al. (2008) showed that precipitation and wind speed are strongly positive related to elevation in the ECSF research area (Table 5.1).

Table 5.1. Meteorological data of four sites of the ECSF research area, after Bendix et al. (2008).

\begin{tabular}{|c|c|c|c|c|c|c|c|}
\hline Site name & $\begin{array}{l}\text { Elevation } \\
\text { (m a.s.l.) }\end{array}$ & $\begin{array}{l}\text { Rain } \\
\left(\mathbf{m m} \mathbf{y r}^{-1}\right)\end{array}$ & $\begin{array}{l}\text { Horizontal } \\
\text { dep. } \\
\left(\mathbf{m m} \text { yr }{ }^{-1}\right)\end{array}$ & $\begin{array}{l}\text { Sum } \\
\left(\mathrm{mm} \mathrm{yr}^{-1}\right)\end{array}$ & $\begin{array}{l}\text { Temp. } \\
(\text { min. } \\
\left.{ }^{\circ} \mathbf{C}\right)\end{array}$ & $\begin{array}{l}\text { Temp. } \\
(\max . \\
\left.{ }^{\circ} \mathbf{C}\right)\end{array}$ & $\begin{array}{l}\text { Aver. wind } \\
\text { speed } \\
\left(\mathrm{m} \mathrm{sec}^{-1}\right)\end{array}$ \\
\hline $\begin{array}{l}\text { ECSF } \\
\text { Research stat. }\end{array}$ & 1960 & 2176 & 121 & 2297 & 5.0 & 29.1 & $1.0-2.0$ \\
\hline Plataforma & 2270 & 2193 & 210 & 2403 & - & - & - \\
\hline TS1 & 2660 & 4779 & 527 & 5306 & 4.7 & 25.5 & $0.5-1.5$ \\
\hline $\begin{array}{l}\text { Cerro } \\
\text { de Consuelo }\end{array}$ & 3180 & 4743 & 1958 & 6701 & 2.6 & 20.7 & $4.5-7.5$ \\
\hline
\end{tabular}

\section{Vegetation}

The description of modern vegetation types and their characteristic vascular plant species of the ECSF research area (Table 5.2) is based on the fieldwork data of Homeier et al. (2008).

The lower montane forest (LMF) occurs between ca. 1300 and $2100 \mathrm{~m}$ a.s.l. with an extremely diverse, two-storied tree stratum and a canopy height up to $30 \mathrm{~m}$. Undisturbed communities of this type can be found particularly on steep slopes with $30^{\circ}$ to $50^{\circ}$ inclination, as well as up to ca. $2300 \mathrm{~m}$ at the bottom of wind-protected river valleys. The upper montane forest (UMF) occurs between ca. 2100 and $2700 \mathrm{~m}$ a.s.l., showing a monotypic formation with only one tree stratum. The canopy heights attain up to $25 \mathrm{~m}$. Between ca. 2700 and $3100 \mathrm{~m}$ a.s.l. the elfin-forest or subpáramo (SUB) vegetation occurs. This vegetation type forms the upper timberline ecotone with a canopy height of $6.8 \mathrm{~m}$. The páramo (PAR) occurs in the crest regions of the Cordillera Real above the upper timberline between ca. 3100 and $3700 \mathrm{~m}$ a.s.l. and attains heights of up to $2 \mathrm{~m}$. 
For describing the upper boundary of closed forest different terms exist. We will use here exclusively the term of upper timberline (UTL) as it is generally used within the "Tropical Mountain Ecosystem" research unit (Richter et al., 2008).

The position of the UTL varies considerably along the neotropical cordilleras. High neotropical timberlines are found between $1^{\circ} \mathrm{N}$ and $17^{\circ} \mathrm{S}$ where the UTL is located between 4000 and $4800 \mathrm{~m}$ a.s.l. and often represented by Polylepis woodlands. Open Polylepis stands even can occur up to $5100 \mathrm{~m}$ a.s.l. (Richter et al., 2008). Bakker et al. (2008) show that the modern UTL in the Guandera Biological Reserve $\left(0^{\circ} 36^{\prime \prime} \mathrm{N}\right)$, near the Ecuadorian-Colombian border, is at ca. $3600 \mathrm{~m}$ a.s.l. In contrast to the high neotropical timberline, the Andean depression region $\left(3^{\circ}-7^{\circ} \mathrm{S}\right)$ holds an especially low neotropical timberline between 2600 and $3360 \mathrm{~m}$ a.s.l. (Weigend, 2002). At the El Tiro-Pass, which is only $10 \mathrm{~km}$ west of ECSF research area, the UTL is between 2790 and $2820 \mathrm{~m}$ a.s.l. In the upper part of the ECSF research area, the UTL is between 2730 and $3040 \mathrm{~m}$ a.s.l. (Richter et al., 2008).

\subsection{Materials and methods}

\section{Vegetation}

A detailed vegetation survey within the ECSF research area along the altitudinal gradient of the Cerro del Consuelo (Table 5.3) is recently available (Diertl, personal communication, 2009) and is used for the ecological grouping of pollen taxa. A set of 24 plots $(2 \times 50 \mathrm{~m})$, following the same trail system as used for the pollen traps, gives detailed information about the surface cover of all terrestrial plants recorded (method after Gentry, 1995). The plots cover an altitudinal range between 2029 and $3011 \mathrm{~m}$ a.s.l. and represent all described vegetation types (LMF, UMF, SUB and PAR). Within the LMF only one plot is available, what has to be considered for comparing data between the vegetation types. Important pollen taxa without an appropriate plant record in the vegetation study of Diertl (personal communication, 2009) were grouped (Table 5.4 using available data from Homeier and Werner (2005), Lehnert et al. (2008) and Marchant et al. (2002). 
Table 5.2. Characteristic vascular plant species for the different vegetation types in the ECSF research area, after Homeier et al. (2008).

\begin{tabular}{|c|c|c|c|}
\hline $\begin{array}{l}\text { Lower montane forest } \\
(1300-2100 \mathrm{~m} \text { a.s.l.) }\end{array}$ & $\begin{array}{l}\text { Upper montane forest } \\
(2100-2700 \mathrm{~m} \text { a.s.l.) }\end{array}$ & $\begin{array}{l}\text { Subpáramo } \\
\text { (elfin forest) } \\
(2700-3100 \text { m a.s.l.) }\end{array}$ & $\begin{array}{l}\text { Páramo } \\
\text { (3100-3700 m a.s.l.) }\end{array}$ \\
\hline $\begin{array}{l}\text { Alzatea verticillata } \\
\text { (Alzateaceae) } \\
\text { Chamaedorea pinnatifrons } \\
\text { Dictyocaryum lamarckianum } \\
\text { Wettinia maynensis } \\
\text { (Arecaceae) } \\
\text { Piptocoma discolor } \\
\text { Mikania spp. } \\
\text { (Asteraceae) } \\
\text { Tabebuia chrysantha } \\
\text { (Bignoniaceae) } \\
\text { Vismia tomentosa } \\
\text { (Clusiaceae) } \\
\text { Cyathea caracasana } \\
\text { (Cyatheaceae) } \\
\text { Inga acreana } \\
\text { Inga spp. } \\
\text { (Fabaceae) } \\
\text { Nectandra lineatifolia } \\
\text { Nectandra membranacea } \\
\text { Ocotea aciphylla } \\
\text { (Lauraceae) } \\
\text { Miconia imitans } \\
\text { Miconia punctata } \\
\text { (Melastomataceae) } \\
\text { Cedrela montana } \\
\text { (Meliaceae) } \\
\text { Ficus spp. } \\
\text { Morus insignis } \\
\text { Sorocea trophoides } \\
\text { (Moraceae) } \\
\text { Piper spp. } \\
\text { (Piperaceae) } \\
\text { Heliocarpus americanus } \\
\text { (Tiliaceae) }\end{array}$ & $\begin{array}{l}\text { Ilex rimbachii } \\
\text { (Aquifoliaceae) } \\
\text { Hedyosmum spp. } \\
\text { (Chloranthaceae) } \\
\text { Clethra revoluta } \\
\text { Purdiaea nutans } \\
\text { (Clethraceae) } \\
\text { Clusia ducu } \\
\text { Tovomita weddeliana } \\
\text { (Clusiaceae) } \\
\text { Weinmannia pinnata } \\
\text { Weinmannia spp. } \\
\text { (Cunoniaceae) } \\
\text { Cyathea bipinnatifida } \\
\text { (Cyatheaceae) } \\
\text { Befaria aestuans } \\
\text { (Ericaceae) } \\
\text { Alchornea grandiflora } \\
\text { (Euphorbiaceae) } \\
\text { Macrocarpaea revoluta } \\
\text { (Gentianaceae) } \\
\text { Eschweilera sessilis } \\
\text { (Lecythidaceae) } \\
\text { Licaria subsessilis } \\
\text { Ocotea benthamiana } \\
\text { Persea ferruginea } \\
\text { (Lauraceae) } \\
\text { Graffenrieda emarginata } \\
\text { Graffenrieda harlingii } \\
\text { Tibouchina lepidota } \\
\text { (Melastomataceae) } \\
\text { Myrica pubescens } \\
\text { (Myricaceae) } \\
\text { Myrsine coriacea } \\
\text { (Myrsinaceae) } \\
\text { Calyptranthes pulchella } \\
\text { Myrcia spp. } \\
\text { (Mytraceae) } \\
\text { Podocarpus oleifolius } \\
\text { Prumnopitys montana } \\
\text { (Podocarpaceae) } \\
\text { Dioicodendron dioicum } \\
\text { Palicourea spp. } \\
\text { (Rubiaceae) } \\
\text { Matayba inelegans } \\
\text { Drimys granadensis } \\
\text { (Winteraceae) }\end{array}$ & $\begin{array}{l}\text { Ilex spp. } \\
\text { (Aquifoliaceae) } \\
\text { Puya eryngioides } \\
\text { (Bromeliaceae) } \\
\text { Hedyosmum cumbalense } \\
\text { Hedyosmum scabrum } \\
\text { (Chloranthaceae) } \\
\text { Clethra ovalifolia } \\
\text { (Clethraceae) } \\
\text { Clusia elliptica } \\
\text { (Clusiaceae) } \\
\text { Weinmannia cochensis } \\
\text { Weinmannia loxensis } \\
\text { Weinmannia rollottii } \\
\text { (Cunoniaceae) } \\
\text { Gaultheria reticulata } \\
\text { (Ericaceae) } \\
\text { Escallonia myrtilloides } \\
\text { (Grossulariaceae) } \\
\text { Orthrosanthus chimborazensis } \\
\text { (Iridaceae) } \\
\text { Persea ferruginea } \\
\text { Ocotea infravoveolata } \\
\text { (Lauraceae) } \\
\text { Gaiadendron punctatum } \\
\text { (Loranthaceae) } \\
\text { Graffenrieda harlingii } \\
\text { (Melastomataceae) } \\
\text { Myrteola phylicoides } \\
\text { (Mytraceae) } \\
\text { Chusquea falcata } \\
\text { Chusquea scandens } \\
\text { (Poaceae) } \\
\text { Hesperomeles ferruginea } \\
\text { (Rosaceae) } \\
\text { Styrax foveolaria } \\
\text { (Styracaceae) } \\
\text { Symplocos sulcinervia } \\
\text { (Symplocaceae) } \\
\text { Gordonia fruticosa } \\
\text { (Theaceae) }\end{array}$ & $\begin{array}{l}\text { Gynoxis spp. } \\
\text { (Asteraceae) } \\
\text { Puya eryngioides } \\
\text { Puya nitida } \\
\text { (Bromeliaceae) } \\
\text { Hypericum decandrum } \\
\text { (Clusiaceae) } \\
\text { Rhynchospora vulcani } \\
\text { (Cyperaceae) } \\
\text { Befaria resinosa } \\
\text { Disterigma pentandrum } \\
\text { Gaultheria erecta } \\
\text { Gaultheria reticulata } \\
\text { Vaccinium floribundum } \\
\text { (Ericaceae) } \\
\text { Escallonia myrtilloides } \\
\text { (Grossulariaceae) } \\
\text { Brachyotum andreanum } \\
\text { (Melastomataceae) } \\
\text { Neurolepis asymmetrica } \\
\text { Neurolepis elata } \\
\text { Neurolepis laegaardii } \\
\text { Chusquea neurophylla } \\
\text { (Poaceae) } \\
\text { Monnina arbuscula } \\
\text { (Polygalaceae) } \\
\text { Valeriana microphylla } \\
\text { Valeriana plantaginea } \\
\text { (Valerianaceae) }\end{array}$ \\
\hline
\end{tabular}




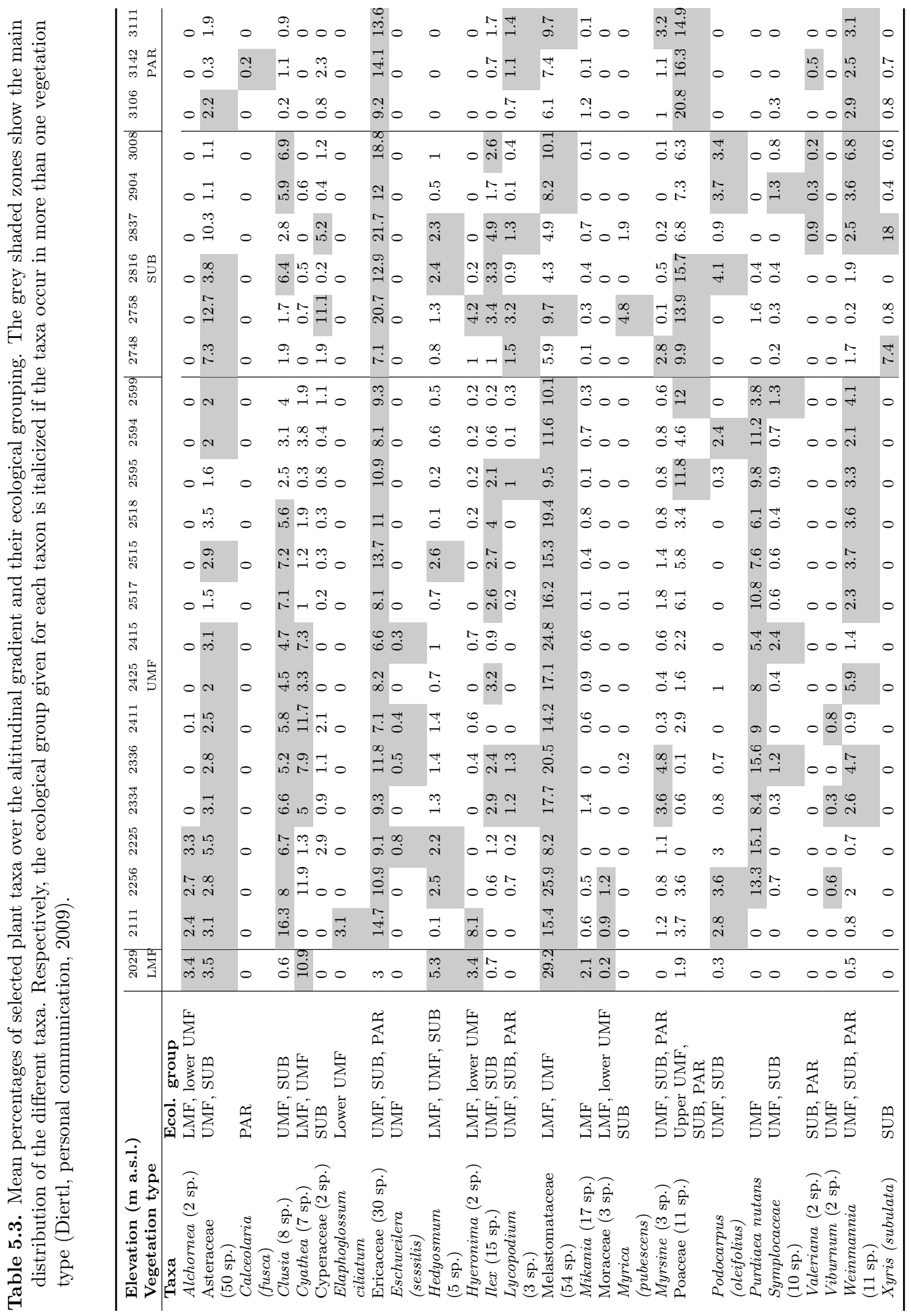


Table 5.4. Additional plant taxa and their ecological grouping.

\begin{tabular}{llll}
\hline Taxa & Vegetation type & Distribution (m a.s.l.) & Reference \\
\hline Acalypha (2 sp.) & LMF & $1800-2000$ & Homeier and Werner, 2005 \\
Alnus & Upper montane rainforests & - & Marchant et al., 2002 \\
Cecropia (4 sp.) & LMF, UMF & $1800-2700$ & Homeier and Werner, 2005 \\
Celtis (1 sp.) & LMF & 1850 & Homeier and Werner, 2005 \\
Clethra (3 sp.) & LMF, UMF & $1800-2700$ & Homeier and Werner, 2005 \\
Croton (1 sp.) & LMF & 1900 & Homeier and Werner, 2005 \\
Heliocarpus (1 sp.) & LMF & $1800-2000$ & Homeier and Werner, 2005 \\
Jamesonia (1 sp.) & SUB & 2900 & Lehnert et al., 2008 \\
Piper (30 sp.) & LMF, lower UMF & $1800-2300$ & Homeier and Werner, 2005 \\
Polystichum (4 sp.) & LMF, UMF & $1800-1900,2500-2600$ & Lehnert et al., 2008 \\
Styrax (3 sp.) & UMF, SUB & $2100-2500,2900-3100$ & Homeier and Werner, 2005 \\
\hline
\end{tabular}

Table 5.5. Site specific data of transects 1 and 2 of modern pollen rain.

\begin{tabular}{llllll}
\hline Site name & $\begin{array}{l}\text { Elevation } \\
(\mathbf{m} \text { a.s.l. })\end{array}$ & Length $(\mathbf{m})$ & $\begin{array}{l}\text { Number of } \\
\text { ident. taxa }\end{array}$ & $\begin{array}{l}\text { Number of } \\
\text { pollen traps }\end{array}$ & Vegetation zone \\
\hline Transect 1 & $1920-3200$ & ca. 5000 & 129 & 27 & LMF, UMF, (Sub-)Páramo \\
Transect 2 & $1810-2420$ & ca. 2300 & 128 & 14 & LMF, UMF \\
\hline
\end{tabular}

\section{Modern pollen rain spectra}

In the ECSF research area a total of 41 pollen traps $(11.5 \mathrm{~cm}$ long plastic tubes with $2.7 \mathrm{~cm}$ in diameter, Fig. 5.3 were installed ca. $20-30 \mathrm{~cm}$ above the ground. The pollen traps were filled with ca. $5 \mathrm{ml}$ glycerine and covered with a synthetic net. The glycerine assures that the pollen remains in the trap during times of high rainfall, which might cause overflows of the traps. Elevation distance between the traps is ca. $50 \mathrm{~m}$ in the range of 1800 to $3185 \mathrm{~m}$ a.s.l. along an existing trail system. After one year (March 2005 to March 2006) the pollen traps were recollected. The ca. $5000 \mathrm{~m}$ long transect 1 starts ca. $70 \mathrm{~m}$ above the valley bottom of the San Francisco river (1920 $\mathrm{m}$ a.s.l.) and reaches the crest region of the Cerro del Consuelo at $3185 \mathrm{~m}$ a.s.l. Transect 2 starts at the valley bottom of San Francisco river $(1810 \mathrm{~m}$ a.s.l.) and is connect to Transect 1 at $2420 \mathrm{~m}$ a.s.l. (Fig. 5.2, Table 5.5). The lowermost samples of transect 2 are located in a disturbed area, therefore this pollen traps have to be excluded from further analysis. Transect 2 in general represents replicated pollen data for the lower part of transect 1. Hence, for the analysis only data derived from transect 1 were used to avoid any disequilibrium in the dataset. Consequently, we present in this study exclusively pollen data of transect 1 with 27 pollen traps installed. The pollen rain data of transect 2 will be used in further studies, focusing on the comparison between pollen rain data within same vegetation types.

The contents of the pollen traps were concentrated in a centrifuge and treated by acetolysis. Before treatment, exotic Lycopodium spores were added to each sample for calculation of pollen accumulation (pollen $/ \mathrm{cm}^{2} /$ year). About 300 pollen grains were counted for each sample. The pollen sum includes trees, shrubs, and herbs and excludes fern spores. Pollen identification relied on the reference collection from the third author with about 3000 neotropical species (Behling, 1993), an Ecuadorian reference collection with about 300 species (collected during fieldwork and from the 


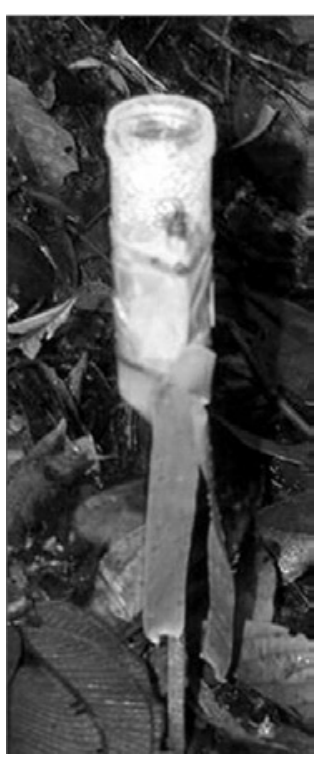

Figure 5.3. Photograph of a pollen trap.

herbarium of the ECSF research station) and literature (Hooghiemstra, 1984).

The ecological grouping of the identified pollen taxa into LMF, UMF, SUB and PAR follows available data after Diertl (personal communication, 2009), Homeier et al. (2008), Homeier and Werner (2005), Lehnert et al. (2008) and Marchant et al. (2002). Pollen and spore data are presented in pollen diagrams as percentages of the pollen sum. The software TILIA and TILIAGRAPH (Grimm, 1987) were used to plot the pollen and spore data. Cluster analysis (CONISS, Grimm, 1987) of pollen and spore taxa was used to identify the pollen zones (Fig. 5.4 and 5.5).

\section{Multivariate analysis}

Principal component analysis (PCA) as an indirect ordination method was used for the statistical analysis of pollen and spore data and the relationship between modern pollen rain and vegetation. The applicability of PCA was verified by a prior detrended correspondence analysis (DCA), which revealed a relatively low gradient length of 1.7 SD. To reduce highly local influences and over-representation of pollen taxa PCA was based on pollen percentages of taxa occurring in at least two samples and with values $>1 \%$ in at least one sample. This resulted in a set of 53 pollen and spore taxa included in the ordination. A log-transformation for the percentage data was chosen to reduce the effect of generally over-represented taxa in the data set. Analysis was carried out by using the Canoco for Windows Version 4.54 software and ordination diagrams were prepared with CanoDraw for Windows 4.13 (ter Braak and Šmilauer, 2002). The same analytical method tested with accumulation rates revealed comparable results. Thus, percentage data were chosen for analysis and interpretation as the data are supposed to be more stable. 


\subsection{Results}

\section{Modern pollen rain transect}

Percentage data of the most abundant and important 38 pollen and spore taxa out of 129 identified taxa are displayed in Fig. 5.4. Additionally, a summary diagram (Fig. 5.5 displays percentages of the vegetation types for every sample based on the ecological grouping of all pollen and spore taxa. The zonation of the diagrams supported by cluster analysis represents the distribution limits of the different vegetation types and the zone names were given accordingly. Pollen taxa from different vegetation types (Fig. 5.4 and 5.5) show a relatively stable representation in zone LMF (ca. 1920-2100 $\mathrm{m}$ a.s.l.) and UMF (ca. 2100-2700 $\mathrm{m}$ a.s.l.). While in zone SUB (ca. 2700-3100 $\mathrm{m}$ a.s.l.) and PAR (>3100 $\mathrm{m}$ a.s.l.) pollen taxa from the UMF decreased and SUB/PAR pollen taxa strongly increased. Pteridophyta spores show their highest amounts in zone LMF and UMF, below ca. $2500 \mathrm{~m}$ a.s.l., and decrease with altitude. Pollen and spore accumulation is highest in Zone LMF (Fig. 5.5).

\section{Multivariate analysis}

PCA displays the pollen traps along the first axis, which strongly correlates (98.5\%) with the altitudinal gradient, revealed by a secondary analysis including elevation as environmental variable (Fig. 5.6 a). The first two axes explain $36.2 \%$ of the total variance in the dataset (axis eigenvalue 0.23, axis 2 eigenvalue 0.12 ). The ordination diagram of the pollen traps indicates according to the elevation gradient the different vegetation types. Pollen traps situated closed together along the first axis represent the same vegetation type as illustrated in Fig. 5.6 a. Based on the results of the PCA (Fig. 5.6 b) 10 key taxa (capital letters) out of the complex pollen assemblage were identified to characterize the vegetation types. Another 11 taxa (lower case letters) show a good correlation with the present vegetation over the altitudinal distribution. A set of 16 important pollen taxa (italics) displayed in the diagram show no statistical relation with the vegetation distribution or a very low influence within the total dataset. Among the remaining 16 taxa, which were included in the analysis but not shown in the ordination diagrams, are taxa of very low influence. These less important pollen and spore taxa might correspond to plants with a wide altitudinal distribution and do not represent a particular vegetation type. For a better understanding how the pollen rain reflects the actual vegetation, PCA results were shown in an additional ordination diagram (Fig. 5.6 c), displaying the position of the pollen taxa relative to the vegetation types. 


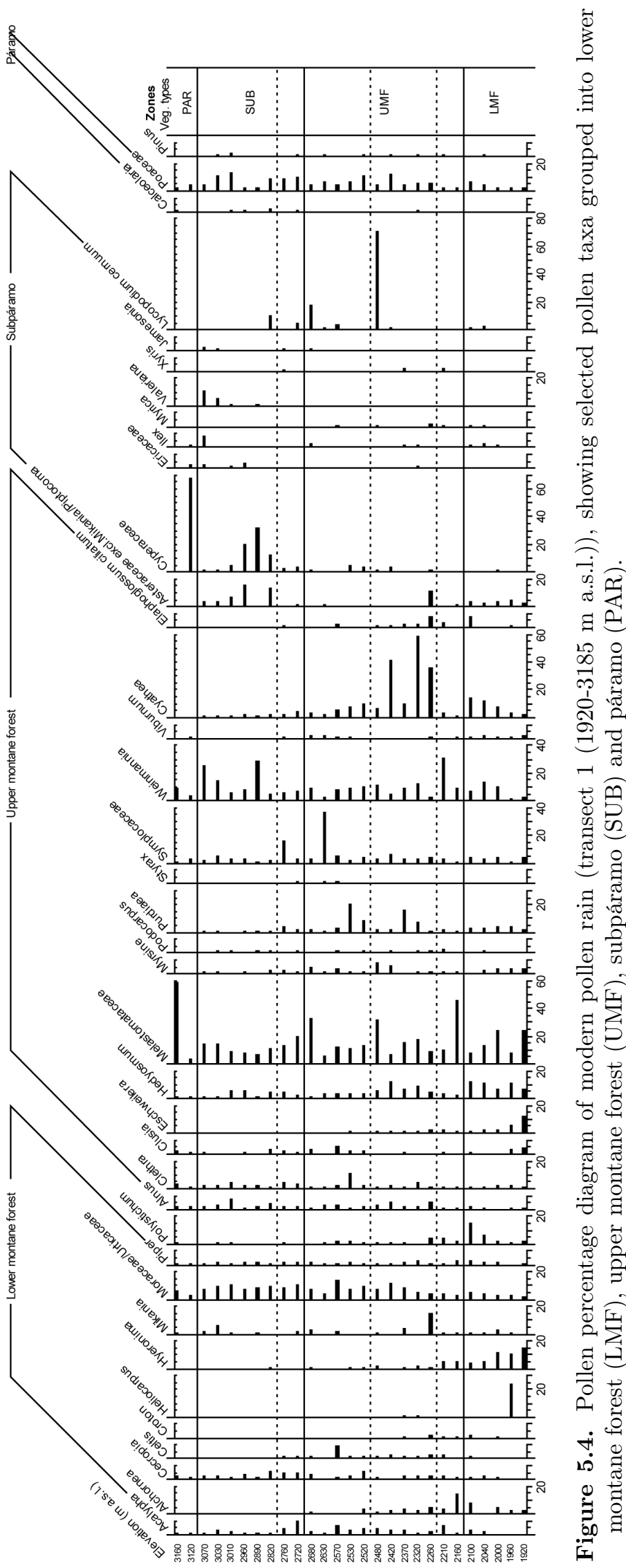




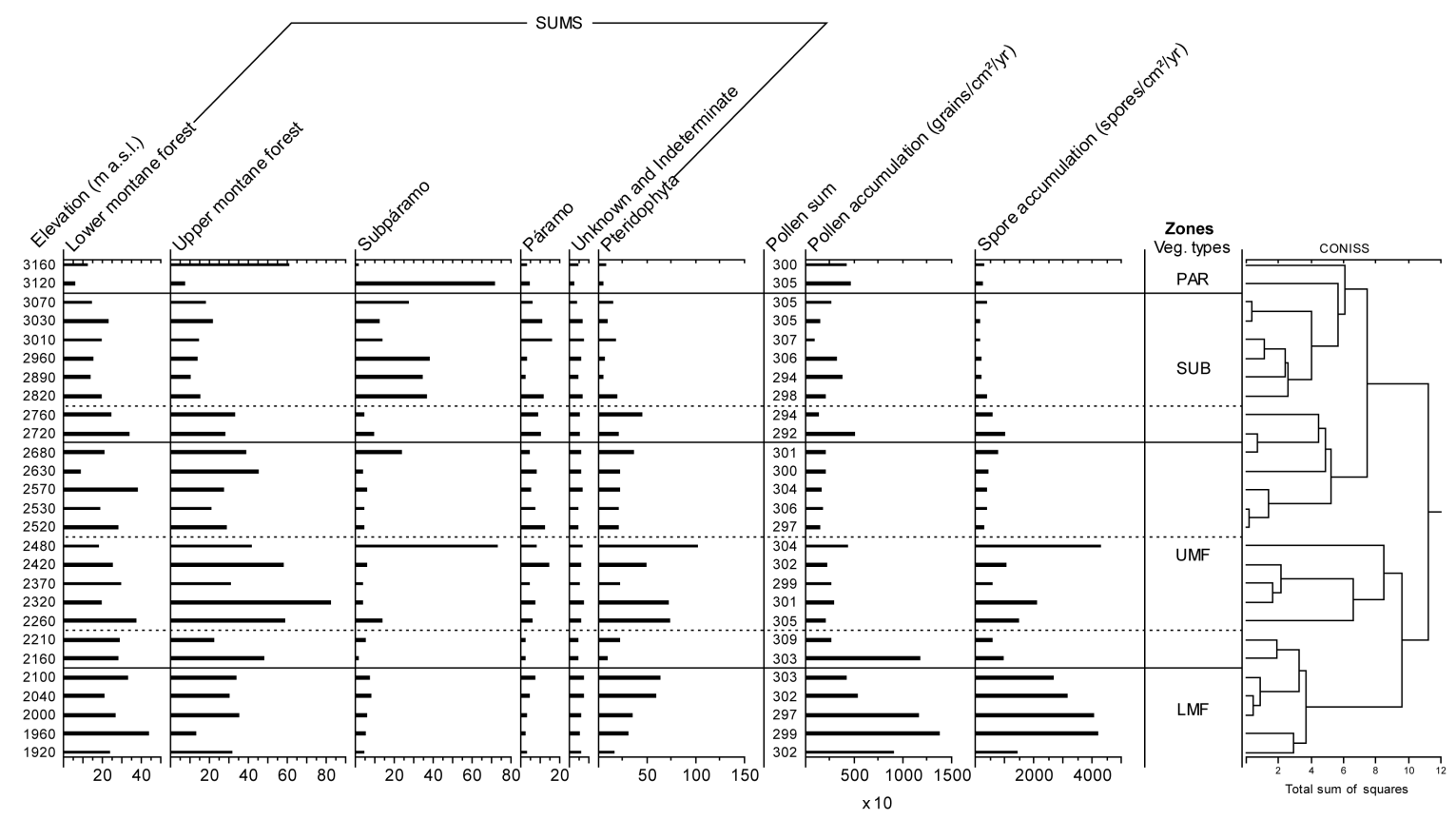

Figure 5.5. Summary diagram of modern pollen rain (transect 1 (1920-3185 m a.s.l.)), showing sums of ecological groups, the pollen sum, the pollen and spore accumulation and the CONISS cluster dendrogram.

\subsection{Interpretation and discussion}

\section{Vegetation/modern pollen rain relationship in the ECSF research area}

The comparison of plant genera and families distribution (Tables 5.3 and 5.4 ) with the respective modern pollen rain taxa (Fig. 5.4 and 5.5 allows to understand the vegetation/modern pollen rain relationship. Multivariate analysis results (Fig. 5.6 a-c) classified pollen and spore taxa (Table 5.6) according to their correlation with the modern vegetation and environmental conditions.

The first group holds pollen taxa representing a single vegetation type. Therefore, these taxa were defined to be key taxa ("++" in Table 5.6). The second group contains important pollen and spore taxa ("+" in Table 5.6) following the altitudinal distribution of plant genera and families of modern vegetation. This means that pollen and spore taxa of this group represent plant distribution patterns but do not reflect single vegetation types. The third group of pollen and spore taxa ("-" in Table 5.6) does not reflect the modern vegetation pattern or are taxa of minor influence for the differentiation between the vegetation types. This is either caused by very low pollen frequencies of the different taxa (Fig. 5.4 and 5.6 b) or by a different pollen distribution compared to the respective plants (Fig. 5.6 c). For the interpretation of the modern pollen rain data it has to be considered that some pollen traps were located beneath individual plants contributing substantially to the pollen accumulation. This causes underrepresentation of other taxa in the percentage diagram. Examples for high values of a single pollen taxon in one pollen trap (Fig. 5.4) are found for Symplocaceae (38\% at $2630 \mathrm{~m}$ a.s.l.), Cyperaceae (65\% at $3145 \mathrm{~m}$ a.s.l.), 


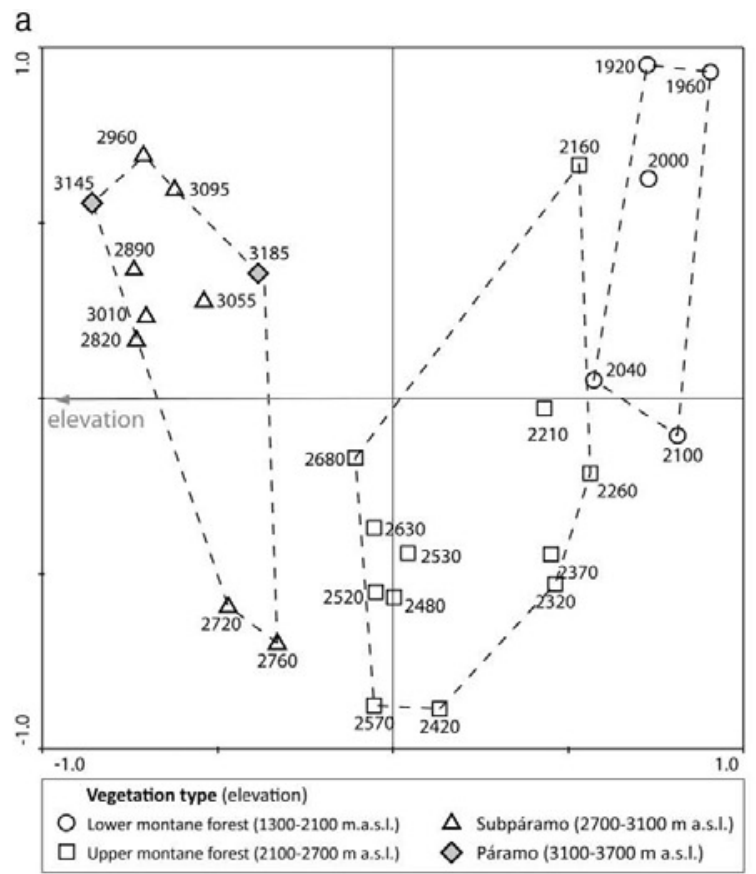

b

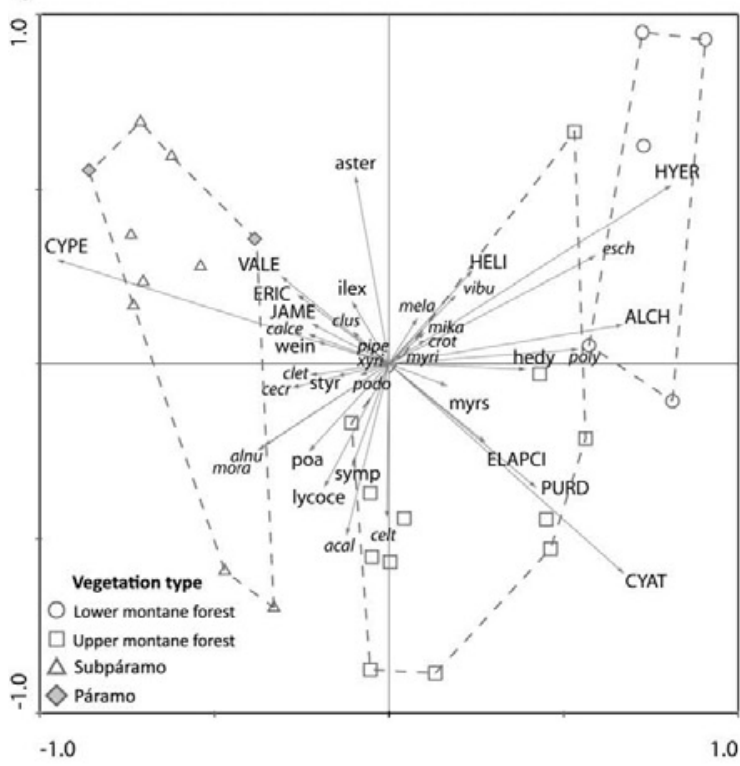

C

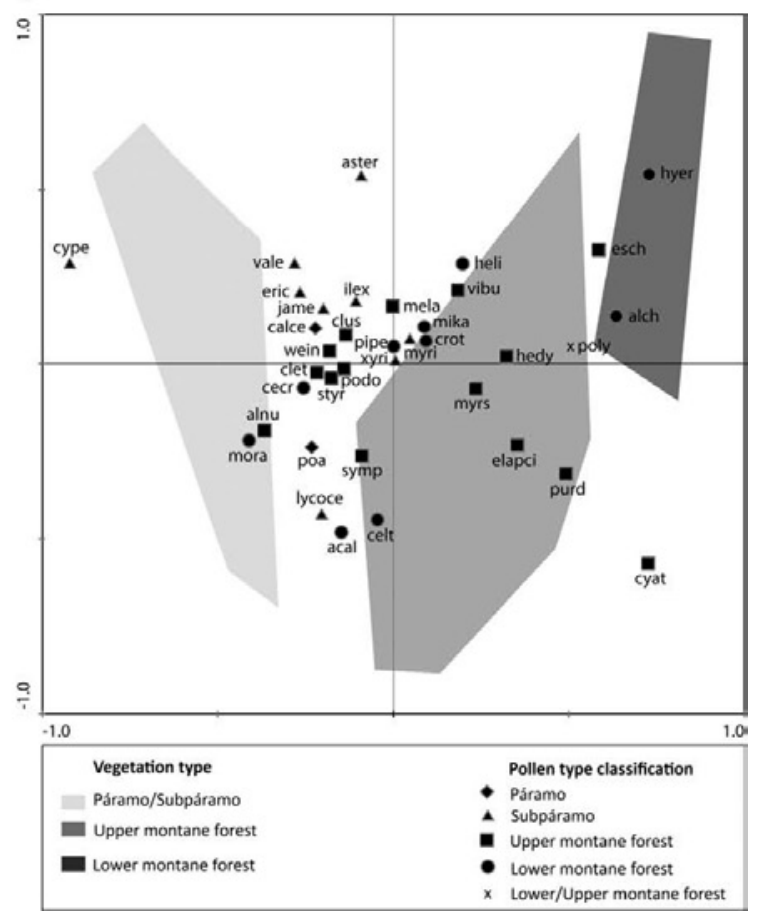

Figure 5.6. a: Ordination diagram (PCA) showing the elevation for all pollen traps and the respective vegetation type after Homeier et al. (2008). The first axis is positive correlated with the altitudinal gradient (elevation). b: Ordination diagram (PCA) showing the 37 pollen taxa and their varying importance (arrow length) for the differentiation of vegetation types along the altitudinal gradient (correlated with axis 1). Key taxa are displayed in capital letters, taxa corresponding to the vegetation patterns are displayed in lower case letters and taxa without any correlation to modern vegetation and/or of low influence are shown in italics. c: Ordination diagram (PCA) showing the 37 taxa (see b) and their ecological grouping. The different vegetation type distribution is displayed as shaded plot in the background. 
Table 5.6. List of abbreviations of pollen/spore taxa in the ordination diagrams (Fig. 5.6 a-c) and classification of pollen/spore taxa: Representing a vegetation type (key taxa, "++"), following the altitudinal distribution of genera and families of modern vegetation (important taxa,"+") and not reflecting modern vegetation structures ("-").

\begin{tabular}{llllll}
\hline Abbreviation & Taxa & Class & Abbreviation & Taxa & Class \\
\hline acal & Acalypha & - & mora & Moraceae/Urticaceae & - \\
alch & Alchornea & ++ & myri & myrs & Myrsine \\
alnu & Alnus & - & pipe & Piper & - \\
aster & Asteraceae & + & poa & Poaceae & - \\
calce & Calceolaria & - & podo & Podocarpus \\
cecr & Cecopia & - & purd & Purdiaea \\
celt & Celtis & - & styr & Symplocaceae \\
clet & Clethra & - & symp & Viburnum \\
clus & Clusia & + & vibu & Valeriana & + \\
crot & Croton & - & vale & Weinmannia \\
cype & Cyperaceae & ++ & wein & Xyris \\
eric & Ericaceae & ++ & xyri & & + \\
esch & Eschweilera & - & & Cyathea \\
hedy & Hedyosmum & + & cyat & Elaphoglossum ciliatum \\
heli & Heliocarpus & ++ & elapci & + \\
hyer & Hyeronima & ++ & jame & Jamesonia \\
ilex & Ilex & + & lycoce & Lycopodium cernuum \\
mela & Melastomataceae & + & poly & Polystichum \\
mika & Mikania & - & & & + \\
\hline
\end{tabular}

Melastomataceae (60\% at $3185 \mathrm{~m}$ a.s.l.) and Lycopodium cernuum type $(75 \%$ at $2480 \mathrm{~m}$ a.s.l.). These local effects should be neglected when inferring general trends.

Important key taxa for the LMF are Alchornea, Heliocarpus and Hyeronima; for the UMF Cyathea spp., Elaphoglossum ciliatum and Purdiaea; and for SUB Cyperaceae, Ericaceae, Jamesonia and Valeriana. Key taxa for PAR could not be defined, which might be due to the low number of recorded pollen and spore taxa (in total 7 taxa) representative for PAR vegetation. Additionally, this few taxa are represented by low percentages. Therefore, PAR taxa which are expected to be common in the uppermost two samples within the PAR vegetation are under-represented in the pollen rain. Key taxa of the study site are plants with a narrow distribution within only one vegetation type. This is represented for the key taxa in the modern vegetation as well as in the pollen rain. Accordingly, the pollen dispersal of these taxa seems to be restricted to the local occurrences of the plants. For Purdiaea this can be explained by the pollination system, as the plant is animal pollinated.

Important taxa not representing a single vegetation type, but following the altitudinal distribution of genera and families of modern vegetation are Asteraceae, Clusia, Hedyosmum, Ilex, Melastomataceae, Myrsine, Poaceae, Styrax, Symplocaceae, Weinmannia and Lycopodium cernuum.

Poaceae are mostly common in PAR vegetation. Pollen of Poaceae generally occurs more frequently in higher elevations, shown by the position in the ordination diagram between SUB and UMF, but highest values were not found in PAR, as expected. A relatively high pollen proportion of Poaceae (5-10\%) in the UMF vegetation type relates either to the occurrence of forest grasses, with high pollen production, or to wind transport from disturbed areas around the ECSF research area, where Poaceae prefer to grow. Comparable results were found in other studies, e.g. pollen rain data 
from the Mera site in Ecuadorian Amazonia show a high representation of Poaceae (up to $70 \%$ ) between 2100 and $2800 \mathrm{~m}$ a.s.l., which may be a result of local pollen input to moss cushions and presumably represents forest grass (Bush et al., 1990). Surface samples from the Junin area in central Peru show higher pollen representation of Poaceae (40-60\%) in the forest zones (up to $3200 \mathrm{~m}$ a.s.l.) than in the shrub land above, which may be attributed to agricultural disturbance (Hansen et al., 1984).

Pollen of Melastomataceae is found in almost same frequencies all over the altitudinal transect. This is also shown for modern vegetation (Table 5.3). Melastomataceae represents one of the most species rich families (55 species, 10 genera) in the study area (Homeier and Werner, 2005), what might explain the wide distribution range. Weinmannia and Hedyosmum are also examples of plants/pollen with a wide distribution range (Table 5.3, Fig. 5.4), which results to a low influence of these taxa for determining vegetation type limits. Important pollen taxa not representing a certain vegetation type and not following the altitudinal distribution of modern vegetation are Acalypha, Alnus, Calceolaria, Cecropia, Celtis, Clethra, Croton, Eschweilera, Mikania, Moraceae/Urticaceae, Myrica, Piper, Podocarpus, Viburnum, Xyris and Polystichum.

Multivariate analysis showed the highest pollen occurrence of LMF taxa Acalypha, Celtis, Cecropia, Croton, Mikania, Moraceae/Urticaceae and Piper in the UMF and in the SUB/PAR vegetation type. This indicates that pollen rain and pollen distribution of these taxa does not reflect the local vegetation pattern. Pollen of the UMF taxa Clethra shows highest occurrence in the SUB/PAR vegetation type (Fig. $5.6 \mathrm{c}$ ). The comparison of modern vegetation distribution in the ECSF research area and its pollen rain suggests a transport of pollen to higher elevations, leading to an overrepresentation of lowland taxa in the UMF and SUB/PAR vegetation types. Strong easterly winds, which blow up the Rio San Francisco valley most likely transport pollen to high elevations. This upslope transport is evident in the statistical analysis as described.

Bush (1991) showed that different types of tropical lowland vegetation produce characteristic and identifiable pollen rains, separating igapo, varzea, terra firme, semideciduous and cerrado sites. Data from Cuyabeno in Ecuador and Manaus in Brazil (Bush et al., 2001) also provide a caution by ecological factors such as climate or soil type. In contrast, tropical highland vegetation offers one more complex dimension the altitudinal gradient, influenced by local wind regimes. Due to the extraordinary high wind speed and prevailing eastern wind direction within the study area a relatively high number of different pollen taxa seems to be widely wind dispersed to higher elevations. This effect might be extremely significant for the pollen rain distribution pattern in the ECSF area compared to other pollen rain studies.

Studies from tropical Andes over an altitudinal gradient show that wind transport over longer distances have to be taken into account. Results from the Mera site in the Ecuadorian Amazonia (Bush et al., 1990) show that between 2100 and $3400 \mathrm{~m}$ a.s.l. Moraceae/Urticaceae pollen is well represented (up to 12\%). Gosling et al. (2009) confirmed recently the assumption that Moraceae/Urticaceae and Cecropia are overrepresented in ecosystems beyond their distribution range. Surface samples along an elevation gradient between 2800 and 3800 m a.s.l. at Laguna Baja in northern Peru show an over-representation of forest pollen (e.g., Hedyosmum), which was attributed 
to low pollen productivity of local plants at high elevations and by long distance wind transport (Hansen and Rodbell, 1995). High proportions of Alnus pollen in the superpuna of the Junin area in central Peru between 4400 and $4900 \mathrm{~m}$ a.s.l. is also related to wind transport (Hansen et al., 1984). Pollen rain data from the High Plains of Bogota in Colombia show low percentages of subandean taxa nearly everywhere between 2600 and $3800 \mathrm{~m}$ a.s.l. (Hooghiemstra and Cleef, 1984).

In contrast, other studies show good correlations between local vegetations and their pollen rain. Data of the Madre de Dios River in southeastern Peru (240 to $3500 \mathrm{~m}$ a.s.l.) show that modern pollen assemblages reflect local floras and provide a characteristic pollen spectrum for each elevation. Forest turnover along an altitudinal gradient provided a strong correlation with changing pollen spectra (Weng et al., 2004). Pollen of Alnus, Hedyosmum, Combretaceae/ Melastomataceae and Poaceae are abundant between 1600 and $2000 \mathrm{~m}$ a.s.l. Alnus pollen is most abundant between 2000 and $2700 \mathrm{~m}$ a.s.l., and Poaceae is rare. Above $2700 \mathrm{~m}$ a.s.l., Asteraceae, the Muehlenbeckia type, Myrsine, Poaceae and Polylepis pollen are dominant (Weng et al., 2004). Vegetation types (Subandean forest, Andean forest, páramo and super páramo) are also reflected in the pollen rain data, from the Sumapaz area, eastern slope of the Central Cordillera, Colombia (1120 and $4250 \mathrm{~m}$ a.s.l.), but with a high input of extraneous pollen (Melief, 1985). But it has to be considered that such comparisons between different pollen rain studies might be difficult due to different distributions of vegetation zones and taxa. And moreover comparing other Andean studies with our study located in the Andean depression is vague and hardly appropriate because of the special environmental conditions in the depression region.

Most modern and fossil pollen diagrams contain primarily wind pollinated taxa. During our palynological study a total of 129 different pollen and spore taxa have been identified for an area which is known to hold more than 130 families, 420 genera and 1200 species of identification demonstrates that most species in the ECSF research area are animal pollinated and often lack in the pollen record. The majority of identified spermatophytes in the ECSF area are Orchidaceae (338 species) and Bromeliaceae (56 species), which produces low numbers of pollen missing in most pollen records. An example of pollen found from animal pollinated taxa is Purdiaea, which shows main pollen proportions between ca. 2300 and $2550 \mathrm{~m}$ a.s.l. (Fig $4 \mathrm{a}$ ). Purdiaea nutans (Clethraceae) is a small evergreen tree with local abundances in montane forests in northern South America. In the Rio San Francisco valley of southeastern Ecuador, P. nutans is dominant between 2150 and $2650 \mathrm{~m}$ a.s.l., where the trees form large stands. Here Purdiaea accounts for up to about $80 \%$ of the individuals, mixed with e.g. Hedyosmum, Melastomataceae, Myrsine and (tree)-ferns (Mandl et al., 2008). The dominance of Purdiaea pollen found between 2300 and $2550 \mathrm{~m}$ a.s.l., shows no shift in pollen distribution according to the vegetation data. Therefore, pollen from animal pollinated species represents the vegetation in our area more accurate. Unfortunately, animal pollinated taxa are rare in the pollen record. The low pollen accumulation rate at altitudes with $P$. nutans dominance reflects this. In a forest with a closed canopy a higher pollen accumulation has to be assumed.

Alnus and Pinus do not occur in the ECSF research area (Homeier and Werner, 2005). The relatively high representation of Alnus (1- $7 \%$ ) and Pinus (0-3\%) pollen 
(Fig. 5.4 indicates long distance pollen transport from outside the ECSF research area. Pinus plantations exist on the opposite slope of the Rio San Francisco valley at about $2 \mathrm{~km}$ distance from the ECSF research area. Alnus trees are also observed at the slopes of the Rio San Francisco valley growing as pioneers in disturbed areas. Comparing the accumulation rates of Alnus and Pinus pollen (not shown in the pollen diagram) it can be outlined, that even if both plants occur at same distances from the study site, the influence of Alnus is much higher than from Pinus. While Pinus pollen is found with max. 40 grains $/ \mathrm{cm}^{2} /$ year, Alnus pollen reaches high accumulations of 120 grains $/ \mathrm{cm}^{2} /$ year in some pollen traps.

Cluster analysis of terrestrial pollen and spore taxa shows a floristic change within the UMF vegetation type at ca. $2500 \mathrm{~m}$ a.s.l. (Fig. 5.5, dotted line between 2480 and $2520 \mathrm{~m}$ a.s.l.). This may reflect a topographical aspect given that between 2480 and $2520 \mathrm{~m}$ a.s.l. the mountain ridge becomes flat and moist. Otherwise this might reflect the limit of Purdiaea dominance.

The diversity of pteridophyta decreases more or less directly with increasing elevation (1920-3185 m a.s.l.) in the ECSF research area (Fig. 5.5). The highest spore proportion at ca. $2480 \mathrm{~m}$ a.s.l. coincides with the distribution of modern fern individuals which show a maximum at ca. $2400 \mathrm{~m}$ a.s.l. (Kessler, personal communication). Pteridophyta spores (e.g. Cyathea and Lycopodium cernuum type) strongly increase in the UMF vegetation type (Fig. 5.4) and modern fern individuals show the highest number of species in the UMF vegetation type, related to a high level of moisture. Data of horizontal rain and cloud/fog water deposition along an altitudinal gradient show the strongest increase of precipitation between $2270 \mathrm{~m}$ a.s.l. (2403 mm) and $2660 \mathrm{~m}$ a.s.l. (5306 mm) (Bendix et al., 2008). This pattern conforms to the spore accumulation rates over the altitudinal gradient of our study (Fig. 5.5). Hence, spore data reflect well the occurrence of pteridophyta at humid locations. The total pollen accumulation decreases in higher elevations as expected. This shows that pollen accumulation is less in open vegetation, compared to forest sites with closed canopies.

Finally, the circumstance that the studied pollen rain presents only data of one year has to be addressed. Pollen rain composition most likely varies over two or three years as the pollen production vary according to plant specific systems and changing climatic conditions over the years. Consequently, results of this study provide a first insight of the pollen rain in the ECSF area and have to be enhanced by additional pollen rain studies in this area.

\section{The reliability of modern pollen rain representing vegetation types}

The distribution of LMF, UMF, SUB and PAR of the ECSF research area is generally well reflected in the modern pollen rain data. A high number of modern pollen taxa represent the altitudinal distribution of plant genera or families of the modern vegetation. The dendrogram provided by cluster analysis verifies the same zonation for the modern pollen rain taxa as described for the vegetation types. Minor changes in elevational limits by analysing the pollen data might reflect the difficulties to define exact distribution limits between vegetation types, as they do not show sharp borders. 
The discrepancy between floral limits and pollen compositional changes can be observed using the dendrogram (Fig. 5.5, dotted lines between 2210 and $2260 \mathrm{~m}$ a.s.l. and between 2760 and $2820 \mathrm{~m}$ a.s.l.). According to Homeier et al. (2008) the LMF vegetation type extends up to $2100 \mathrm{~m}$ a.s.l. and the following UMF vegetation type to $2700 \mathrm{~m}$ a.s.l. Cluster analysis of pollen rain data reflects an uplift of ca. $100 \mathrm{~m}$ for the upper limits of LMF and UMF. This upslope shift of the vegetation type limits reflected by the pollen data probably is related to the uphill pollen transport by wind, as discussed above.

A change of floristic composition at ca. $2790 \mathrm{~m}$ a.s.l. is reflected by an increase of SUB pollen and a decrease of LMF and UMF pollen (Fig. 5.5, dotted line between 2760 and $2820 \mathrm{~m}$ a.s.l.). This changeover is in the same altitudinal range of the present day UTL in the research area, which is between 2730 and $3040 \mathrm{~m}$ a.s.l. (Richter et al., 2008). Pollen proportion of all LMF and respectively UMF taxa are $<25 \%$ above ca. $2800 \mathrm{~m}$ a.s.l. (Fig. 5.5), not considering the exception of a probably local occurrence of Melastomataceae in the uppermost pollen trap. Hence, the UTL seems to be reflected in the pollen composition by the decrease of forest pollen taxa below 25\%. The increase of PAR taxa may be not as important as the decreases of forest taxa, because of the under-representation of PAR taxa in the pollen rain. In regions outside the Andean depression not only the UTL is located at higher elevations but also vegetation types in general have higher distribution limits. The vegetation zonation after Van der Hammen (1974) for the tropical Cordillera Oriental locate the Subandean forest at elevations between ca. 1000 and $2500 \mathrm{~m}$ a.s.l., the Andean forest from ca. 2500 to $3500 \mathrm{~m}$ a.s.l. and the (sub)-páramo from ca. 3500 to $4200 \mathrm{~m}$ a.s.l. At Laguna Baja in the Cordillera Oriental of Peru the border between wet montane forest and páramo vegetation is at about $3400 \mathrm{~m}$ a.s.l. (Hansen and Rodbell, 1995). The comparable low position of vegetation types and UTL in the ECSF research area might be a result of the Andean depression and the unique climatic conditions (Richter et al., 2008). The zone of "low Neotropical UTL" is between $3^{\circ}$ and $7^{\circ} \mathrm{S}$, within the so-called Amotape-Huancabamba Floristic Zone (Weigend, 2002). The UTL depression results from the absence of the high elevation genus Polylepis, which probably is caused by the extremely high precipitation in the eastern Andean chain in northern Peru and southern Ecuador. Polylepis tends to avoid perhumid mountain regions (Kessler, 1995).

The change of the floristic composition between ca. 3070 and $3120 \mathrm{~m}$ a.s.l. (Fig. 5.5) might reflect the border between SUB and PAR. However, this remains speculative as the compositional change in the pollen record is not that obvious. Additionally, the two locally high occurrences from Melastomataceae and Cyperaceae in the uppermost pollen traps might have overprinted the general pattern of the pollen rain. Due to the last transect sample at $3185 \mathrm{~m}$ a.s.l., further studies in elevations higher than $3185 \mathrm{~m}$ a.s.l. are needed to study the transition between SUB and PAR in detail. 


\subsection{Summary and conclusions}

Statistical analysis (PCA) on the pollen rain data revealed a high number of pollen and spore taxa representing a vegetation type or following the altitudinal distribution of genera and families of modern vegetation.

Characteristic pollen and spore taxa (key taxa) for the LMF are Alchornea, Heliocarpus and Hyeronima, for the UMF Cyathea spp., Elaphoglossum ciliatum and Purdiaea and for the SUB Cyperaceae, Ericaceae, Jamesonia and Valeriana. However, there are also a considerable number of pollen taxa not reflecting the modern vegetation structure. This is mostly due to a wide distribution pattern of pollen and plant taxa. But over-representation in higher elevations of pollen taxa originating from lower locations plays a significant role, too.

Wind dispersal is supposed to be responsible for the high occurrences of the LMF pollen taxa in the UMF and SUB/PAR vegetation types and a high proportion of $\mathrm{UMF}$ pollen taxa in the SUB/PAR vegetation type. Wind dispersal is rarely discussed posing a problem in fossil pollen records. The results of this study clearly point out the importance of this discussion. This is especially important for the ECSF study area, where strong easterly winds occur.

Cluster analysis verified the different altitudinal limits of the vegetation types LMF, UMF, SUB and PAR reflected by the modern pollen rain. Only minor differences were observed. Therefore, palynological studies on modern and fossil pollen data can be used to reconstruct the vegetation in the study area and the dynamics of the altitudinal distribution. The modern UTL in the research area, indicated by the pollen record between ca. 2760 and $2820 \mathrm{~m}$ a.s.l., is mainly reflected by low amounts $<25 \%$ of montane forest taxa above the UTL.

The strong influence of upslope wind dispersal of different pollen taxa, e.g. of Moraceae/Urticaceae and Alnus, have to be taken into account for the interpretation of fossil pollen records in this region. It is also important to know, that PAR taxa seems to be under-represented in the pollen rain. Poaceae is one of the most characteristic plant families occurring in PAR vegetation, but the family shows highly homogenous pollen dispersion in all vegetation types. Hence, frequently recorded Poaceae pollen in fossil pollen records have to be interpreted with caution, as Poaceae generally are associated with PAR vegetation. To sum up, the compositional change of different pollen taxa gives more reliable information on vegetation changes than single taxa may do.

\subsection{Acknowledgements}

Felix Matt is thanked for logistical support and for information about the study region. We thank Valerio Pillar for the introduction in multivarite data analysis, Jürgen Homeier for using his species lists and his collected flush samples and Peter von Schnakenberg as well as Achim Bräuning for collecting the pollen traps. We want to thank Karl-Heinz Diertl for the kind provision of his vegetation data. The projects FOR 402/D1 and FOR 816 (Be 2116/8-1) are kindly funded by the Deutsche Forschungsgemeinschaft (DFG). 


\subsection{References}

Bakker, C., Moscol Olivera, M., Hooghiemstra, H., 2008. Holocene environmental change at the upper timberline in northern Ecuador. Holocene 18, 1-17.

Barthlott, W., Mutke, J., Rafiqpoor, M.D., Kier, G., Kreft, H., 2005. Global centres of vascular plant diversity. Nova Acta Leopoldina 92, 61-83.

Beck, E., Bendix, J., Kottke, I., Makeschin, F., Mosandl, R., 2008a. Gradients in a Tropical Mountain Ecosystem of Ecuador. Ecological Studies, vol. 198. Springer Verlag, Berlin, Heidelberg.

Beck, E., Makeschin, F., Haubrich, F., Richter, M., Bendix, J., Valerezo, C., 2008b. The Ecosystem (Reserva Biológica San Francisco). In: Beck, E., Bendix, J., Kottke, I., Makeschin, F., Mosandl, R. (Eds.), Gradients in a tropical mountain ecosystem of Ecuador. Ecological Studies, vol. 198. Springer, Berlin, Heidelberg, pp. 1-14.

Behling, H., 1993. Untersuchungen zur spätpleistozänen und holozänen Vegetationsund Klimageschichte der tropischen Küstenwälder und der Araukarienwälder in Santa Catarina (Südbrasilien). Dissertationes Botanicae 206, J. Cramer, Berlin, Stuttgart.

Bendix, J., Fabian, P., Rollenbeck, R., 2004. Gradients of Fog and Rain in a Tropical Montane Cloud Forest of Southern Ecuador and Its Chemical Composition. Proceedings 3rd Int. Conference on Fog, Fog Collection and Dew, 11-15 Oct. 2004, Cape Town, South Africa.

Bendix, J., Rollenbeck, R., Richter, M., Fabian, P., Emck, P., 2008. Climate. In: Beck, E., Bendix, J., Kottke, I., Makeschin, F., Mosandl, R. (Eds.), Gradients in a tropical mountain ecosystem of Ecuador. Ecological Studies, vol. 198. Springer, Berlin, Heidelberg, pp. 63-74.

Brunschön, C., Behling, H., 2009. Late Quaternary vegetation, fire and climate history reconstructed from two cores at Cerro Toledo, Podocarpus National Park, southeastern Ecuadorian Andes. Quaternary Research 72, 388-399.

Bush, M., 1991. Modern pollen-rain data from South and Central America: a test of the feasibility of fine-resolution. Holocene 1, 162-167.

Bush, M.B., Colinvaux, P.A., Wiemann, M.C., Piperno, D.R., Liu, K.B., 1990. Late Pleistocene temperature depression and vegetation change in Ecuadorian Amazonia. Quaternary Research 34, 330-345.

Bush, M., Moreno, E., DeOlivera, P.E., Asanza, E., Colinvaux, P.A., 2001. The influence of biogeographic and ecological heterogeneity on Amazonian pollen spectra. Journal of Tropical Ecology 17, 729-743. 
Gentry, A., 1995. Patterns of diversity and floristic composition in Neotropical Montane Forests. In: Churchill, S.P., Balslev, H., Forero, E., Luteyn, J.L. (Eds.), Biodiversity and Conservation of Neotropical Montane Forests. The New York Botanical Garden Press, pp. 103-126.

Gosling, W.D., Mayle, F.E., Tate, N.J., Killeen, T.J., 2009. Differentiation between Neotropical rainforest, dry forest and savannah ecosystems by their modern pollen rain spectra and implications for the fossil pollen record. Review of Palaeobotany and Palynology 153, 70-85.

Grimm, E.C., 1987. CONISS: a Fortran 77 program for stratigraphically constrained cluster analysis by the method of the incremental sum of squares. Computer and Geosciences 13, 13-35.

Hansen, B.C.S., Rodbell, D.T., 1995. A Late-Glacial/Holocene pollen record from the eastern Andes of northern Peru. Quaternary Research 44, 216-227.

Hansen, B.C.S., Wright, H.E., Bradbury, J.P., 1984. Pollen studies in the Junin area, central Peruvian Andes. Geological Society of America Bulletin 95, 1454-1465.

Homeier, J., Werner, F.A., 2005. Preliminary Checklist of the Spermatophytes of the Reserva San Francisco (Province Zamora-Chinchipe, Ecuador). Department of Plant Ecology, Albrecht-von-Haller-Institute for Plant Sciences, University of Göttingen, Göttingen.

Homeier, J., Werner, F.A., Gradstein, S.R., Breckle, S.-W., Richter, M., 2008. Potential Vegetation and Floristic Composition of Andean Forests in South Ecuador, with a Focus on the RBSF. In: Beck, E., Bendix, J., Kottke, I., Makeschin, F., Mosandl, R. (Eds.), Gradients in a tropical mountain ecosystem of Ecuador. Ecological Studies, vol. 198. Springer, Berlin, Heidelberg, pp. 87-100.

Hooghiemstra, H., 1984. Vegetation and Climatic History of the High Plain of Bogota, Colombia. Dissertationes Botanicae. 79, J. Cramer, Vaduz.

Hooghiemstra, H., Cleef, A.M., 1984. Development of vegetation and climatic sequence of the area of the high plain of Bogota. In: Hooghiemstra, H. (Ed.), Vegetation and Climatic History of the High Plain of Bogota, Colombia. Dissertationes Botanicae. 79, J. Cramer, Vaduz, pp. 67-133.

Kessler, M., 1995. Polylepis-Wälder Boliviens: Taxa, Ökologie, Verbreitung und Geschichte. Dissertationes Botanicae 246 J, Cramer, Vaduz.

Lehnert, M., Kessler, M., Salazar, L.I., Navarrete, H., Werner, F.A., Gradstein, S.R., 2008. Checklist to the Pteridophytes of the Reserva Biológica San Francisco (Prov. Zamora-Chinchipe, Ecuador). In: Liede-Schumann, S., Breckle, S.W. (Eds.), Provisional checklists of fauna and flora of the San Francisco valley and its surroundings (Reserva San Francisco/Prov. Zamore-Chinchipe, southern Ecuador): Ecotropical Monography, vol. 4, pp. 59-69. 
Mandl, N., Lehnert, M., Gradstein, S.R., Kessler, M., Abiy, M., Richter, M., 2008. The Unique Purdiaea nutans Forest of Southern Ecuador - Abiotic Characteristics and Cryptogamic Diversity. In: Beck, E., Bendix, J., Kottke, I., Makeschin, F., Mosandl, R. (Eds.), Gradients in a tropical mountain ecosystem of Ecuador. Ecological Studies, vol. 198. Springer, Berlin, Heidelberg, pp. 275-280.

Marchant, R., Almeida, L., Behling, H., Berrio, J.C., Bush, M., Cleef, A., Duivenvoorden, J., Kappelle, M., De Oliveira, P., Teixeira de Oliveira-Filho, A., LozanoGarcia, S., Hooghiemstra, H., Ledru, M.P., Ludlow-Wiechers, B., Markgraf, V., Mancini, V., Paez, M., Prieto, A., Rangel, O., Salgado-Labouriau, M.L., 2002. Distribution and ecology of parent taxa of pollen lodged within the Latin American Pollen Database. Review of Palaeobotany and Palynology 121, 1-75.

Melief, A.B.M., 1985. Late Quaternary Paleoecology of the Parque Nacional Natural los Nevados (Cordillera Central), and Sumapaz (Cordillera Oriental) Areas, Colombia. Doctoral Thesis. University of Amsterdam, 162 pp.

Niemann, H., Behling, H., 2008. Late Quaternary vegetation, climate and fire dynamics inferred from the El Tiro record in the southeastern Ecuadorian Andes. Journal of Quaternary Science 23 (3), 203-212.

Niemann, H., Behling, H., 2009a. Late Pleistocene and Holocene environmental change inferred from the Cocha Caranga sediment and soil records in the southeastern Ecuadorian Andes. Palaeogeography, Palaeoclimatology, Palaeoecology $276,1-14$.

Niemann, H., Behling, H., 2010. Late Holocene environmental change and human impact inferred from three soil monoliths and the Laguna Zurita multi-proxy record in the southeastern Ecuadorian Andes. Vegetation History and Archaeobotany 19, 1-15.

Niemann, H., Haberzettl, T., Behling, H., 2009. Holocene climate variability and vegetation dynamics inferred from the (11700 cal yr BP) Laguna Rabadilla de Vaca sediment record, southeastern Ecuadorian Andes. Holocene 19 (2), 307-316.

Richter, M., Moreira-Muñoz, A., 2005. Climatic heterogeneity and plant diversity in southern Ecuador experienced by phytoindication. Review of Peruvian Biology $12,217-238$.

Richter, M., Diertl, K.-H., Peters, T., Bussmann, R.W., 2008. Vegetation Structures and Ecological Features of the Upper Timberline Ecotone. In: Beck, E., Bendix, J., Kottke, I., Makeschin, F., Mosandl, R. (Eds.), Gradients in a tropical mountain ecosystem of Ecuador. Ecological Studies, vol. 198. Springer, Berlin, Heidelberg, pp. 275-280. 
ter Braak, C.J.F., Šmilauer, P., 2002. CANOCO Reference Manual and CanoDraw for Windows User's Guide: Software for Canonical Community Ordination (version 4.5). Microcomputer Power, Ithaca NY, USA. 500 pp.

Van der Hammen, T., 1974. The Pleistocene changes of vegetation and climate in tropical South America. Journal of Biogeography 1, 3-26.

Weigend, M., 2002. Observations on the biogeography of the Amotape-Huancabamba zone in northern Peru. Botanical Review 68, 38-54.

Weng, C., Bush, M., Silman, M.R., 2004. An analysis of modern pollen rain on an elevational gradient in southern Peru. Journal of Tropical Ecology 20, 113-124. 


\section{Chapter 6 .}

\section{Supplementary study on palynological richness as a measure for plant diversity in the tropical Andes hotspot}

\subsection{Background}

\section{Palynological richness in biodiversity research - state of the art}

Biodiversity, as essential part of the world's ecosystems, has been an important area of research in ecology and conservation for a long time. With respect to expected future climate changes and biodiversity loss, factors and regulation mechanisms influencing biodiversity levels are gaining more and more attention. Under environmental aspects, e.g. geographical, ecological, but also historical factors have contributed to the accruement of regions with extraordinarily high levels of diversity. Thus, these factors are also important for the maintenance of biodiversity hotspots (Beck and Richter, 2008).

Fossil pollen data provides long-term and continuous insights into plant diversity development, the reason why these data may be a good measure for biodiversity history (Willis et al., 2007). However, a suitable and satisfactory method for measuring pollen diversity, and for estimating plant diversity based on these data, has not yet been fully developed. The most common and possibly most meaningful way of representing pollen diversity is the number of pollen and spores detected in pollen records, i.e. palynological richness (see Weng et al., 2006). Birks and Line (1992) introduced rarefraction analysis for estimating palynological richness based on standardized pollen counts. This approach is now widely used in the palynological community. However, several methodological limitations have to be addressed before relating palynological richness to plant diversity. These include among other factors, e.g. the relationship of palynological richness with pollen concentration and evenness (Peros and Gajewski, 2008), the low taxonomic identification levels of pollen taxa, and the frequent absence of rare taxa due to limited count sizes of pollen samples (Weng et al., 2006, 2007). In general, plant identification is more advanced than pollen identification. Therefore, description of plant diversity pattern may be simpler when using vegetation surveys instead of pollen records. However, "complete" diversity can neither be gathered by plant nor by pollen data. Nevertheless, with a limited number of samples, diversity or species richness can be approximately described (e.g. alpha diversity), and diversity patterns may be detectable (e.g. beta diversity). According to Odgaard (2001), it is suggested to compare modern pollen datasets with 


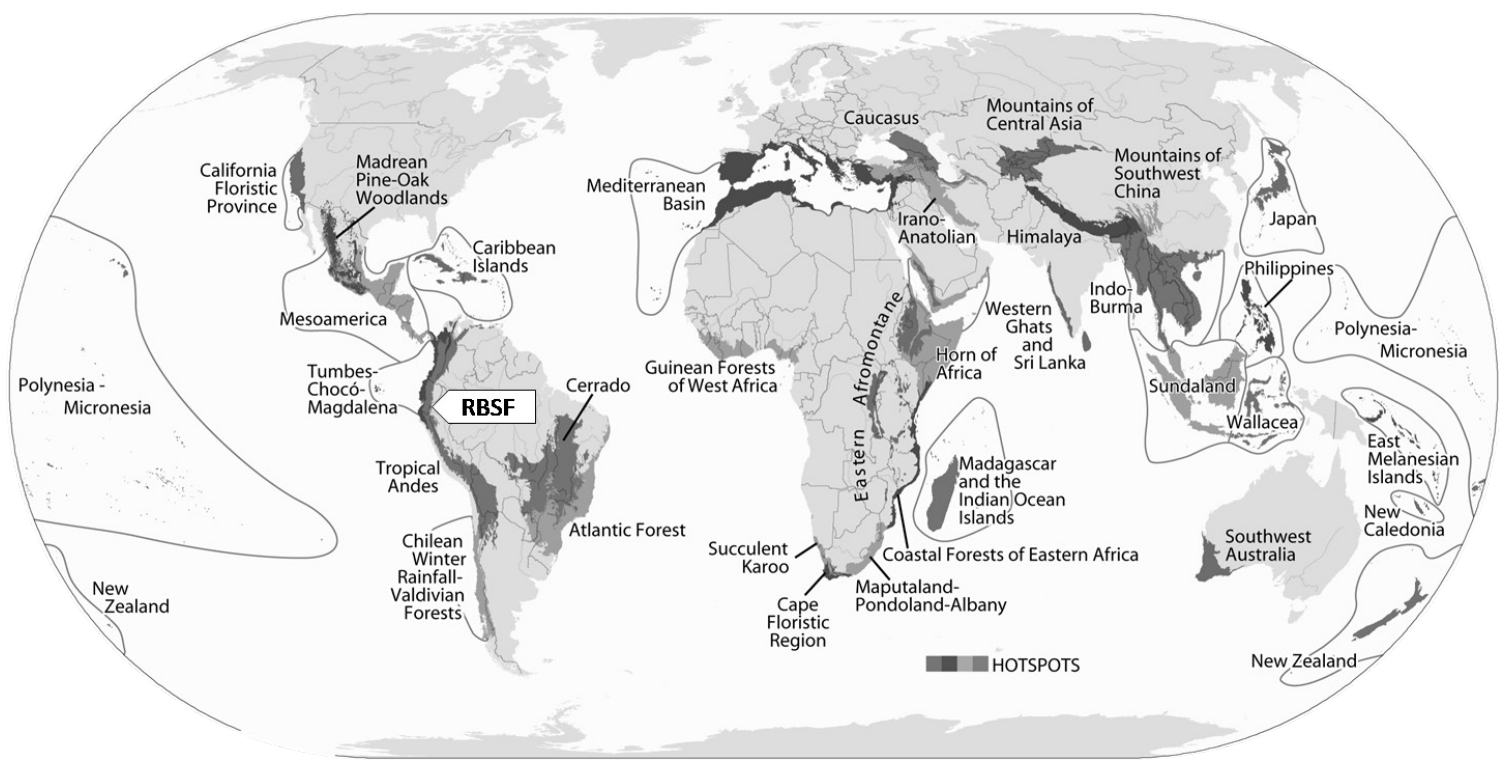

Figure 6.1. Currently recognized biodiversity hotspots (34) by Conservation Internationa 1 and the location of the Reserva Biológica San Francisco (RBSF) within the tropical Andes hotspot.

vegetation diversity, in order to enhance the knowledge of the relationship between palynological richness and plant diversity.

\section{Diversity patterns of the Reserva Biológica San Francisco}

Several working groups of the DFG (Deutsche Forschungsgemeinschaft) research unit FOR 816 (former FOR 402) focus their investigations on the Reserva Biológica San Francisco (RBSF). This area is located within the biodiversity hotspot of the tropical Andes in southern Ecuador, which represents one of the five global centers of vascular plant diversity with $>5,000$ species per $10,000 \mathrm{~km}^{2}$ (Barthlott et al., 2007; Beck et al., 2008; Richter et al., 2009, Fig. 6.1). The region of the RBSF covers elevations from ca. 1800 to $3160 \mathrm{~m}$ a.s.l. and is part of the northern Podocarpus National Park (PNP). The scientists identified an extraordinarily high quantity of animal and plant species within the small area (ca. $11 \mathrm{~km}^{2}$ ) of the RBSF. Results of the working groups were used to elucidate biodiversity history and development in the study region (Beck and Richter, 2008; Richter et al., 2009). For this purpose, palynological data obtained so far in the wider area of the PNP substantially contributed to the understanding of past environmental changes (see previous chapters). However, profound knowledge of past biodiversity still remains poor. This is one reason why future investigation of the palaeoecological working group within the DFG research unit FOR 816 will concentrate, inter alia, on past diversity dynamics and the response of biodiversity to environmental changes.

As detected for other regions, decreasing plant diversity and forest stature with increasing elevation was confirmed for the RBSF (Homeier et al., 2008; Richter et al., 2009). On closer examination, this area shows the so-called mid-domain-effect

\footnotetext{
1 map source: http://www.biodiversityhotspots.org/xp/hotspots/resources/Pages/maps.aspx [15.03.2010]
} 
(Colwell and Lees, 2000; Colwell et al., 2004), which implies maximum diversity at mid-range elevations (Richter et al., 2009). Considering the different vegetation types and their altitudinal distribution in the study area (Homeier et al., 2008), plant diversity generally decreases from the vegetation types of mountain rainforests at midrange altitude (lower and upper mountain rainforest) to the high-altitude vegetation types of subpáramo and páramo above the upper forest line.

\section{Research approach and objective}

If the vegetation diversity pattern in the RBSF (as per description above) is reliably reflected in vegetation plots and pollen traps, a decrease in plant and pollen diversity with increasing elevation will be expected in such records. Available vegetation and pollen data, collected at a similar altitudinal range in the RBSF (Niemann et al., 2010; see chapter 5), allow an initial analysis of plant species richness and pollen diversity patterns. The analysis pursues the following research questions at this point:

(1) Do records of plant species and palynological richness reflect decreasing diversity with increasing elevation in the RBSF? Which differences can be detected between different vegetation types, e.g. closed forest and open páramo?

(2) Are the data basis and the selected approach appropriate for such an investigation?

(3) Is a highly diverse area suitable for such studies?

(4) What has to be considered for future investigations and the interpretation of fossil pollen data related to past plant diversity?

\subsection{Data basis for diversity measures}

For the estimation of palynological richness, one year of pollen rain data, obtained from 27 pollen traps along an altitudinal transect between 1920 and $3185 \mathrm{~m}$ a.s.l. in the RBSF, were used (for detailed data description see chapter 5). Palynological richness is defined here as the total number of identified pollen and spore taxa including unknown pollen types. Rarefraction analysis was omitted, as the count size of all pollen samples is nearly identical (ca. 300 pollen grains).

A vegetation survey, based on 24 vegetation plots $(2 \times 50 \mathrm{~m})$ along an altitudinal gradient between ca. 2030 and $3010 \mathrm{~m}$ a.s.l. in the RBSF, was used to calculate terrestrial plant species richness (Diertl, personal communication, 2009; see chapter $5)$. The original data as well as data adapted to taxonomic levels attainable by pollen identification were analyzed in this approach.

Both data sets were collected during individual studies at the slopes of the mountain "Cerro del Consuelo". The transects cover the same ridge above ca. $2500 \mathrm{~m}$ a.s.l., whereas lower sample sites are located at two different ridges up to ca. $1 \mathrm{~km}$ apart. In addition to that, pollen and plant sample sites were neither collected at exactly the same altitudes nor do they overlap. Therefore, data are not directly comparable and only give first indications of parallels or differences by the conduction of indirect comparison. 


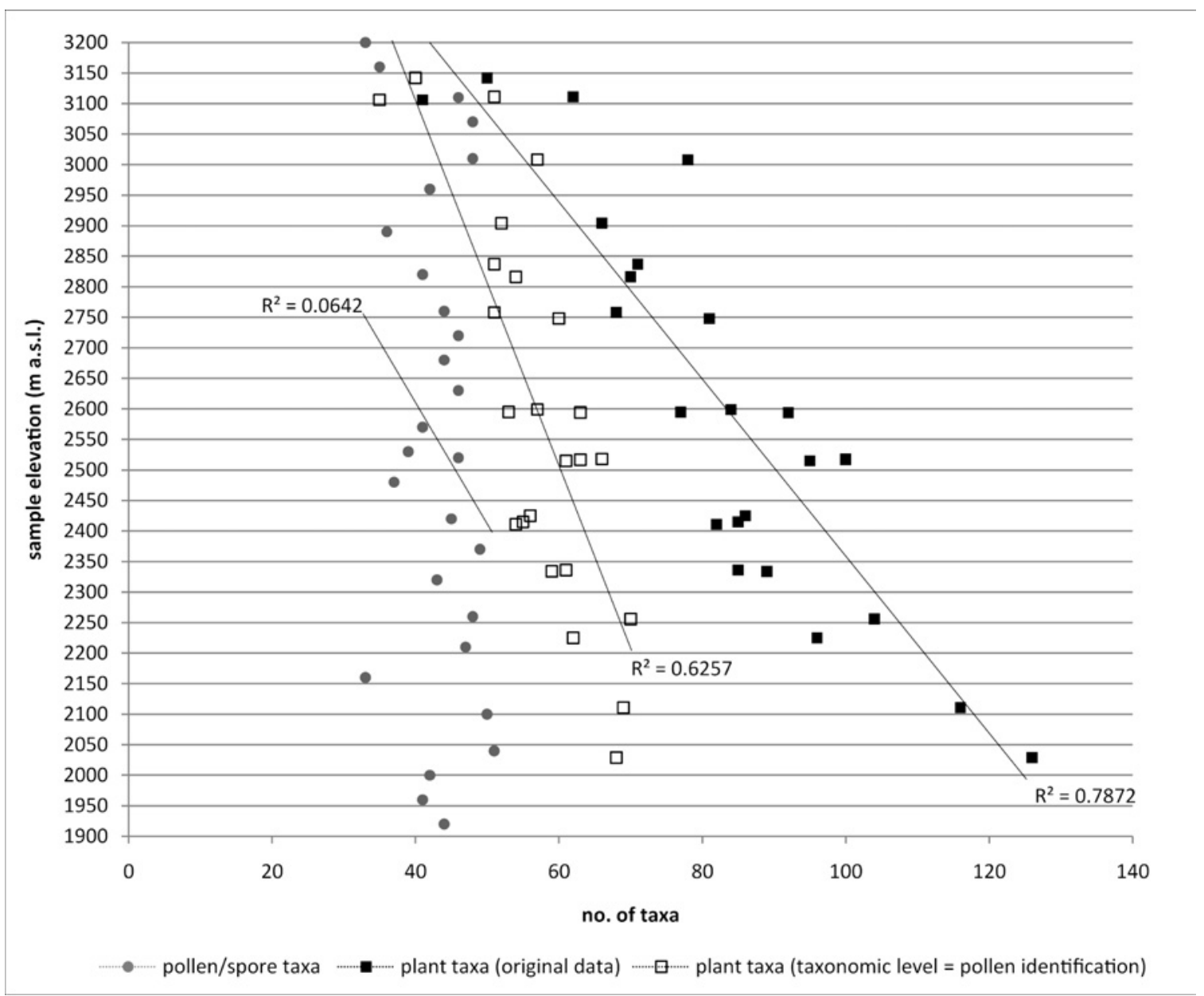

Figure 6.2. Palynological richness and plant diversity along an altitudinal gradient in the RBSF. Records of plant taxa are displayed as original data and as data adapted to same taxonomic levels as of pollen taxa. The linear regression lines and coefficients of determination $\left(\mathrm{R}^{2}\right)$ are shown, describing the relation between altitude and pollen or plant data, respectively.

\subsection{Results}

The total diversity, meaning the total number of different taxa found along the complete gradient, account for 123 pollen/spore taxa and 563 plant taxa. Breaking down the taxonomic level of the recorded plant taxa to an identification level comparable to that of pollen taxa, plant diversity still remains ca. 50\% higher with 180 taxa.

When observing the diversity along the altitudinal gradient (Fig. 6.2), a trend of decreasing plant diversity with increasing altitude is shown. The highest diversity, with 126 plant taxa, is observed in samples of the lowest locations within lower mountain rainforest. Following a more or less continuous decrease in diversity, the lowest plant species numbers, between 62 and 41 taxa, are found in samples of the highest locations within páramo vegetation. The same trend is indicated by vegetation data of a taxonomic level comparable to that of pollen taxa (Fig. 6.2).

A simple linear regression with a coefficient of determination $\left(R^{2}\right)$ describes the likelihood of a supposed (linear) correlation between altitude and diversity of the 
sample data. The results show that the correlation between plant diversity (original data) and altitude is high with $\mathrm{R}^{2}=0.79$, which stands for an explained variance of $79 \%$ of the data set (Fig. 6.2). The correlation between altitude and plant species richness with plant taxa adapted to the lower taxonomic levels as of pollen taxa is still high $\left(\mathrm{R}^{2}=0.62\right)$.

Palynological richness along the entire gradient generally varies between 41 and 51 pollen and spore taxa per sample, excluding two outliers of the samples at 2160 and $2890 \mathrm{~m}$ a.s.l., with 33 and 36 taxa, and the uppermost two samples sites above $3110 \mathrm{~m}$ a.s.l., with 35 and 33 taxa (Fig. 6.2). A clear trend along the altitudinal gradient cannot be recognized for pollen diversity, as shown by a low correlation between palynological richness and altitude with $\mathrm{R}^{2}=0.06$, meaning an explained variance of the data set of $6 \%$ (Fig. 6.2). However, the highest palynological richness is found in samples of lower elevations (2040-2100 m a.s.l.), and a partly continuous decreasing trend is recorded in samples of locations higher than $3000 \mathrm{~m}$ a.s.l., with the overall lowest richness in the uppermost two samples sites (Fig. 6.2).

Analysis of the correlation between diversity and altitude for the limited elevations of different vegetation types (not graphed) is applied to detect and compare trends within closed forest and open vegetation above the upper forest line (subpáramo/páramo), respectively. The results show a relative low correlation between altitude and plant diversity within closed forest $\left(\mathrm{R}^{2}=0.32\right)$. Similarly, the correlation between altitude and palynological richness is here very low $\left(\mathrm{R}^{2}=0.01\right)$. Observing the relations within the high altitude sites of subpáramo and páramo vegetation, a relatively high correlation $\left(\mathrm{R}^{2}=0.51\right)$ is indicated between plant diversity and elevation. Likewise, a higher correlation between altitude and palynological richness is here indicated with an explained variance of the data set of $11 \%\left(R^{2}=0.11\right)$.

\subsection{Discussion}

First of all, the quality and reliability of the pollen data basis have to be addressed. It has to be considered, that the data basis for palynological richness only is a one year collection of modern pollen rain, which rather provides first indications than final conclusions on the representation of vegetation diversity. One year of pollen deposition ignores inter-annual variability, e.g. in pollen production and distribution, and reduces the possibility to record rare pollen taxa. Additionally, it has to be mentioned that some pollen traps were installed close to an existing trail system. This disturbance factor may have influenced the recorded palynological richness of certain samples.

However, even with the available pollen data of just one year, first insights can be given into patterns of palynological richness in relation to vegetation diversity in the highly diverse area of the RBSF. Moreover, further essential research questions that need to be considered in future investigations may be detected at this time.

It can be outlined that the trend of overall decreasing diversity from mid-elevations to the crest regions generally is well reflected by the data of plant species richness. For palynological richness, a trend of decreasing diversity along the entire gradient is 
only suggested with a low probability. However, pollen diversity was lowest in the uppermost sample sites and highest in the lower ones. Within more open high-altitude vegetation of subpáramo and páramo, the gradient of plant and pollen diversity is more obvious than within forested sites at lower elevations. Hence, a certain similarity between vegetation and pollen data exists. Unfortunately, a direct comparison between pollen and plant data is not feasible at this point, as sample sites are not identical. It is likely that high-altitude environmental conditions may cause stronger diversity gradients within the subpáramo and páramo vegetation than at lower elevations. As samples in páramo sites are underrepresented in both data sets (3 samples), the inclusion of as many samples within forest as within páramo vegetation, would possibly reveal better recognizable patterns of plant and pollen diversity.

When comparing pollen with plant diversity, it has to be considered that the scales of diversity measures may be different. The recorded plant species richness reflects local or alpha diversity of the $2 \times 50 \mathrm{~m}$ vegetation plots. In contrast, data of palynological richness reflect alpha diversity at different scales, depending on pollen source area, pollen distribution patterns and surrounding vegetation structures of the pollen sample sites (Weng et al., 2006). Generally overrepresented anemophilous taxa in pollen records may be less effective airborne and transported to be deposited in closed vegetation types than in open habitats (Odgaard, 1999). For the RBSF, this means that palynological richness probably reflects local diversity in closed mountain rainforest, whereas in treeless páramo sites and crest regions the pollen signal reflects both the local diversity as well as a greater regional signal. An enhancement of palynological richness in higher elevations is also supported by strong winds in the study area, transporting pollen of anemophilous plants into higher elevations (Niemann et al., 2009, see chapter 5). The larger scale or source area for pollen diversity in open vegetations may cause an increase in palynological richness within subpáramo and páramo compared to forested sites, thereby reducing the comparability of samples and the clarity of a trend.

Factors influencing the palynological richness have to be discussed at this point as well. As mentioned above, the number of different pollen and spore taxa to be recorded is limited by the time interval of data collection. Several years of pollen data will inevitably count for higher palynological richness than one year of pollen deposition. Palynological richness also depends on the sample count size (Weng et al., 2006), the reason why rarefraction analysis was developed (Birks and Line, 1992). Weng et al. (2006) showed for a site in tropical Colombia that a clear asymptote was not even reached with a pollen count of 3000 grains. Data of a fossil pollen record in the PNP show that only a small ratio of the total pollen and spore diversity is reflected in samples of small count sizes (Fig. 6.3). The comparison of samples of generally higher and lower palynological richness indicates that an asymptote may be reached even later in samples of higher richness (Fig. 6.3). Palynological studies in tropical regions use a prevalent count size of 300 pollen grains, which expectably cannot reflect the high plant diversity of the tropics. However, vegetation plot data reflect only parts of the "complete" diversity, too. If overall plant diversity patterns are described based on pollen or vegetation records, it is important to know which sample number or count size is needed. In relation to a total count size of 500- 


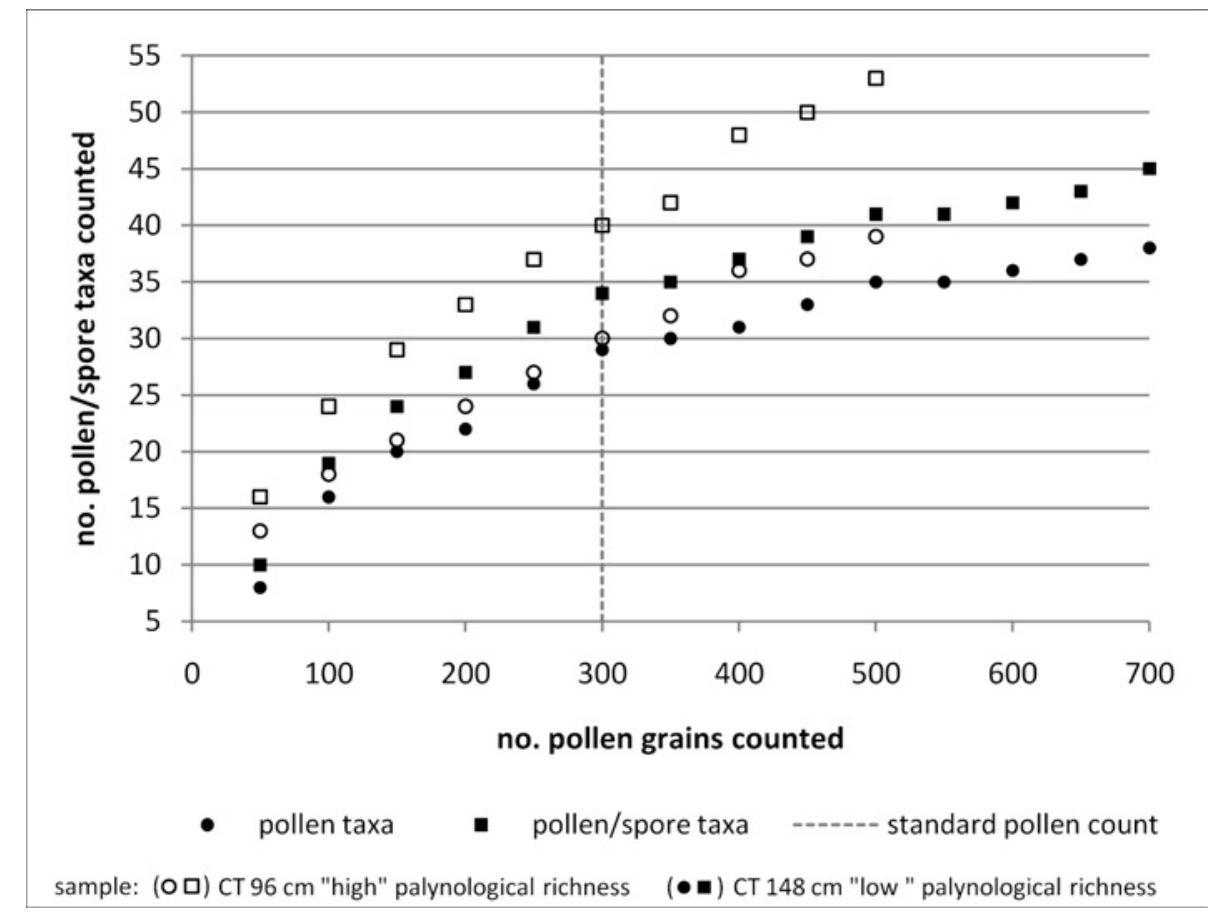

Figure 6.3. Number of different pollen and spore taxa identified for different count sizes. Example data are derived from two fossil samples (96 and $148 \mathrm{~cm}$ sediment depth) of the Cerro Toledo (CT) record (see chapter 2 and Fig. 6.4.

700 grains, 300 pollen grains reflect at maximum ca. $75 \%$ of palynological richness in a pollen sample of the study region (Fig. 6.3). Therefore, 300 pollen grains should be considered as minimum requirement for measuring diversity in pollen samples.

Other studies showed that palynological richness also is depended on pollen concentration and evenness. Different analyses revealed that palynological richness increases with decreasing pollen concentration as well as with increasing evenness (Weng et al., 2006; Peros et al., 2008). Therefore, Weng et al. (2006) suggested another proxy for diversity measures to correct the palynological richness with the pollen accumulation rate, but methodology is not completed yet. However, the decreasing trend of pollen and spore accumulation with increasing elevation observed in the modern pollen data (see chapter 5, Fig. 5.5) may have an influence on the palynological richness. Accordingly, this would imply a reduced palynological richness in samples with higher accumulation rates, which were observed in the lowest samples sites. Hence, the low probability of a relationship between pollen diversity and altitude could be changed to a contrary trend not comparable to the vegetation diversity pattern at all.

In the study area, a great part of the plant diversity is reflected by only a few families. More than one third of all plant species found in the vegetation plots is represented by the following families: Asteraceae ( 49 species), Bromeliaceae (27 species), Melastomataceae (63 species), Orchideaceae (40 species) and Rubiaceae (30 species). In contrast, the following pollen types were recorded for the same plant families: Asteraceae (8 types), Bromeliaceae (not recorded), Melastomataceae (2 types), Orchideaceae (not recorded), Rubiaceae (4 types). This demonstrates that low taxo- 
Table 6.1. The 10 most important plant families in the the RBSF in terms of numbers of genera and species (Table after Homeier and Werner (2007)).

\begin{tabular}{lll}
\hline Family & Genera & Species \\
\hline Orchidaceae & 57 & 338 \\
Rubiaceae & 25 & 62 \\
Bromeliaceae & 8 & 56 \\
Melastomataceae & 10 & 55 \\
Piperaceae & 2 & 44 \\
Lauraceae & 9 & 43 \\
Asteraceae & 17 & 43 \\
Araceae & 5 & 32 \\
Ericaceae & 14 & 25 \\
Myrtaceae & 7 & 18 \\
\hline
\end{tabular}

nomic levels in pollen identification may be one reason for the difficulty in reflecting vegetation diversity based on pollen data.

Homeier and Werner (2007) described the ten most important plant families contributing to the high diversity for the study region in terms of genera and species numbers (Table 6.1). Because of an incomplete pollen reference collection for the study region, pollen can rarely be identified at genera and species levels. For most of the above listed families, pollen identification often remains at family level. To name but a few, Melastomataceae pollen can be distinguished in only two types, whereas the knowledge of the pollen morphology of Asteraceae and Ericaceae allows identifying various genera and species, but the level of plant identification cannot be reached here. Pollen of Orchidaceae and Bromeliaceae are scarcely found in pollen records. For these plant families this can be explained by a pollen dispersion relying on animals instead of wind.

However, even if pollen diversity only represents a certain and may be small part of the floral diversity, temporal changes in palynological richness still provide opportunities to detect relative changes in diversity through time. Certainly, to avoid false conclusions, interpretations in this context have to consider all factors mentioned to have an influence on pollen diversity.

\subsection{Consequences for future research approaches estimating past biodiversity based on fossil pollen data in a highly diverse area}

Palynological richness of fossil pollen data is often interpreted as an approximate measure of past floral diversity on a landscape scale (e.g. Behling and Pillar, 2007; Berglund et al., 2008; Seppä, 1998; Weng et al., 2007). Even though palynological richness may be positively related to plant species richness (Odgaard, 1994), several studies indicated a complicated relationship (e.g. Odgaard, 1999; Peros and Gajewski, 2008; Weng et al., 2006, 2007). Especially for highly diverse areas, like the tropics, additional verifications about the reflection of vegetation diversity by palynological richness may be essential. Weng et al. (2007) proved the representation of vegetation diversity in tropical Colombia by establishing a relationship between pollen diversity 


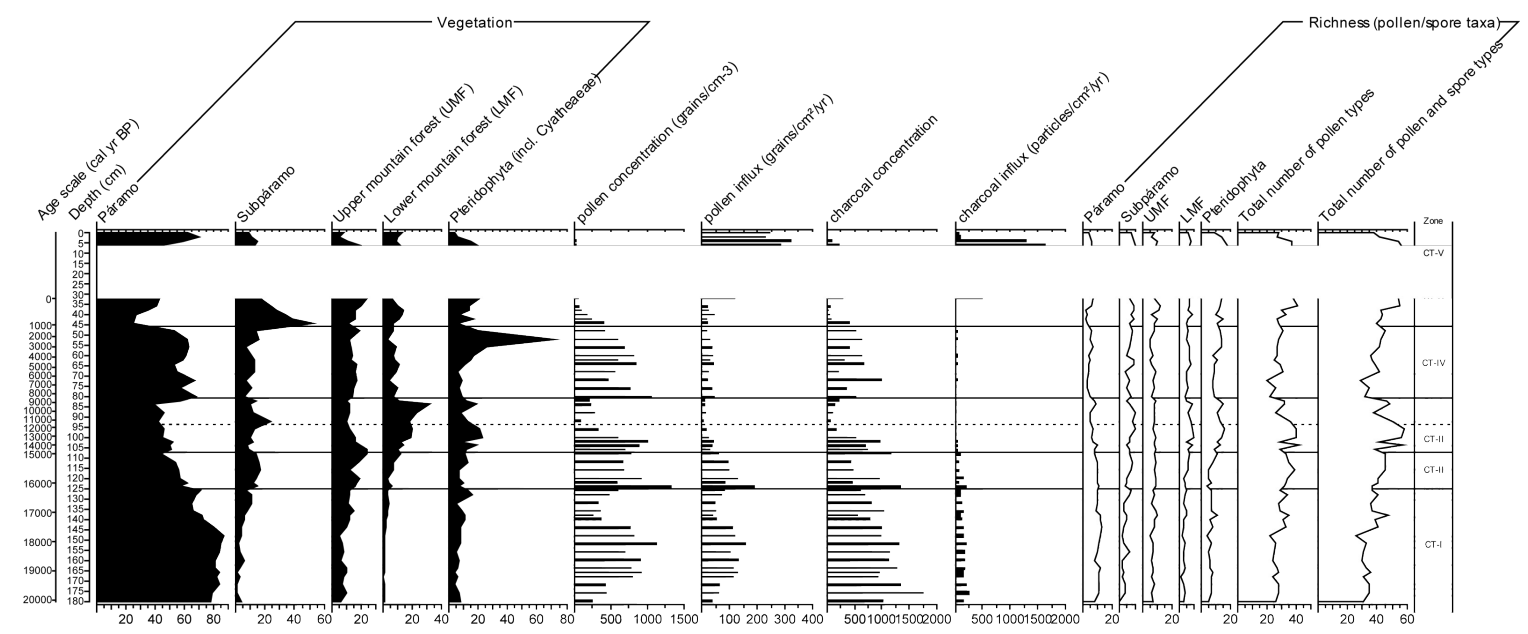

Figure 6.4. Summarized pollen percentage diagram including palynological richness of the Cerro Toledo (CT) core, which is located near the study site RBSF (data basis see chapter 2).

and abundance found within vegetation types of different diversity levels. Finally, for this area it was concluded that pollen diversity of fossil records may provide an important proxy to reconstruct temporal changes in plant diversity.

So far, results of this study approach indicate similarities between patterns of plant diversity and palynological richness in the RBSF. However, further conclusions cannot be drawn, as a direct relationship between palynological and plant species richness could not be analyzed in this study. For the reconstruction of past diversity changes in the biodiversity hotspot of the RBSF and surroundings, analyses with an enhanced data basis, e.g. of top soil samples at representative pollen and vegetation record sites along a diversity gradient, are needed.

However, to exemplify the interpretation of palynological richness of a fossil pollen record, an analyzed bog core taken near the RBSF (ca. $40 \mathrm{~km}$ south) at a highaltitude páramo site (Cerro Toledo (CT), see chapter 2) is selected here (Fig. 6.4). Palynological richness observed in this record indicates continuously increasing vegetation diversity from the last glacial maximum until the transition to the Holocene (Fig. 6.4). As interpreted by Weng et al. (2007), this may be a result of warming climatic conditions, which allows more species-rich vegetation from lower elevations to move upslope. Accordingly, more pollen diversity can possibly be found at the sample site. With the onset of the Holocene, palynological richness decreases. Then, towards most recent times diversity seems to increase again. This may be correlated with different factors, e.g. climate dynamics or habitat disturbances. Behling and Pillar (2007) showed for a southern Brasilian highland that dry climatic conditions reduce plant diversity, whereas wet conditions allow a higher diversity. They also stated that small-scale (natural) disturbances can increase diversity, whereas strong interventions have negative effects. In the pollen record presented here, diversity is relatively high even during times of enhanced disturbances, which are known to have taken place in most recent times (see charcoal influx in Fig. 6.4). This supports the assumption that vegetation diversity may be favored by a certain degree of disturbance. 
The reliability of such interpretations and other conclusions depends on multiple factors discussed within this work. In the presented pollen record of Cerro Toledo, highest palynological richness coincides with low pollen concentration (Fig. 6.4). Furthermore, some pollen samples show less evenness than others (peaks in pollen abundances shown in Fig. 6.4 are mainly due to one single pollen type). How do these circumstances influence the palynological richness found in this record, and how do possible dependencies need to be included in the interpretation?

A relation between pollen abundance of different vegetation types and palynological richness seems to exist here, as it shown by Weng et al. (2007). Pollen diversity is lowest during times when less species-rich páramo vegetation is widely distributed around the study site, whereas diversity increases when more species-rich vegetation (mountain forest) is found at less distance to the study site than before (Fig. 6.4). Hence, spatial diversity dynamics can interact with temporal changes. What results will follow, if relating palynological richness to a varying pollen influx (Fig. 6.4)? While interpreting pollen influx, the quality of the time control for the sediment has to be considered, too. Does a pattern observed in one record coincide with results of other study sites in the same region?

All these questions should be addressed before interpreting fossil pollen data in terms of plant diversity changes through time. This may help to develop a good interpretative basis for this highly diverse study area in the southeastern Andes of Ecuador.

\subsection{Closing remarks}

To sum up, answers to the main research questions introduced at the beginning of this chapter are given here:

(1) Do records of plant species and palynological richness reflect decreasing diversity with increasing elevation in the RBSF? Which differences can be detected between different vegetation types, e.g. closed forest and open páramo?

The general trend of decreasing diversity with increasing elevation was well reflected by plant species richness observed in the vegetation plots along the gradient investigated in the RBSF. In contrast, pollen data did not indicate a significant relation between palynological richness and altitude along the entire gradient. However, the highest palynological richness was found in lower samples sites and the lowest in the uppermost ones. Samples above $3000 \mathrm{~m}$ a.s.l. within subpáramo and páramo vegetation showed a continuous decreasing trend of palynological richness with increasing altitude for this limited elevation interval. The relationship between altitude and diversity, regarding both plant and pollen data, was considerably less expressed within the closed forest than within the high-altitude subpáramo and páramo sites. Hence, a certain similarity between patterns of palynological richness and plant diversity is indicated. However, when interpreting palynological richness, variable pollen source areas within the different vegetation structures, and thus different sizes of the representative areas, have to be considered. On the other hand, plant species richness reflects diversity in the same sized vegetation plots. These circumstances, as well as 
other factors influencing palynological richness, may cause more difficulties to detect the gradient of diversity by pollen data than by vegetation data.

(2) Are the data basis and the selected approach appropriate for such an investigation?

The comparison of modern pollen and vegetation diversity along a diversity gradient generally is a good approach for testing the relationship between pollen and vegetation data. With such studies, important background information can be provided for the interpretation of past diversity dynamics in fossil pollen records. However, a good data basis is indispensable for a reliable and direct comparison of plant diversity with palynological richness. The pollen data set used in this study is not sufficient for a precise analysis. Final conclusions cannot be drawn at this point. To improve the preliminary outcomes of this study, data of representative soil surface samples along a diversity gradient, or some years of modern pollen rain, should be analyzed. Same sample sites for pollen and vegetation data must be used for analyses of direct relationships. A representative set of soil surface samples, representing several years of pollen deposition in one sample, would be more comparable to fossil pollen data than annual pollen rain data.

(3) Is a highly diverse area suitable for such studies?

A great part of the vegetation diversity in the study area of the RBSF cannot be detected by pollen data, as taxonomic level of identification often is low. Hence, using palynological richness as measure for vegetation diversity is a complex intend in such a highly diverse region. The detection of plant diversity in species-rich regions may be more difficult than it would be in less diverse areas. Therefore, to identify as many different pollen types as possible is essential for describing plant diversity, and it will considerably influence the reliability of the data. Identifications should reach more than family level if in any way possible.

(4) What has to be considered for future investigations and the interpretation of fossil pollen data related to past plant diversity?

As explained in the answer to question 2, ample pre-examination and a good data basis are still needed to analyze the relationship between pollen and plant diversity in detail and to be able to make direct comparisons. This is important for future studies and a fundamental prerequisite for the use of palynological richness of fossil pollen data as indicator for changes in vegetation diversity. Palynological richness is subject to complex interactions, as discussed in this study. Special caution is need when interpreting diversity changes based on pollen data and at least all of the stated challenges have to be considered. 


\subsection{References}

Barthlott, W., Hostert, A., Kier, G., Küper, W., Kreft, H., Mutke, J., Rafiqpoor, M. D., Sommer, J. H., 2007. Geographic patterns of vascular plant diversity at continental to global scales. Erdkunde 61, 305-315.

Beck, E., Richter, M., 2008. Ecological aspects of a biodiversity hotspot in the Andes of southern Ecuador. Biodiversity and Ecology Series 2, 195-217.

Beck, E., Makeschin, F., Haubrich, F., Richter, M., Bendix, J., Valerezo, C., 2008. The Ecosystem (Reserva Biológica San Francisco). In: Beck, E., Bendix, J., Kottke, I., Makeschin, F., Mosandl, R. (Eds.), Gradients in a tropical mountain ecosystem of Ecuador. Ecological Studies vol. 198, Springer, Berlin, Heidelberg, pp. 1-13.

Behling, H., Pillar, V.D.P., 2007. Late Quaternary vegetation, biodiversity and fire dynamics on the southern Brazilian highland and their implication for conservation and management of modern Araucaria forest and grassland ecosystems. Philosophical Transactions of the Royal Society of London - Biological Sciences $362,243-251$.

Berglund, B.E., Gaillard, M.-J., Björkman, L., Persson, T., 2008. Long-term changes in floristic diversity in southern Sweden: palynological richness, vegetation dynamics and land-use. Vegetation History and Archaeobotany 17, 573-583.

Birks, H.J.B., Line, J.M., 1992. The use of rarefaction analysis for estimating palynological richness from Quaternary pollen-analytical data. The Holocene 2, $1-10$.

Colwell, R.K., Lees, D.C., 2000. The mid-domain effect: geometric constraints on the geography of species richness. Trends in Ecology and Evolution 15, 70-76.

Colwell, R.K., Brehm, C., Gotelli, N.J., 2004. The mid-domain effect and species richness patterns: what have we learnd so far? American Naturalist 163, E1E23.

Homeier, J., Werner, F.A., 2007. Preliminary checklist of the spermatophytes of the Reserva San Francisco (Prov. Zamora-Chinchipe, Ecuador). In: LiedeSchumann, S. and Breckle, S.W., (Eds.) Provisional Checklists of Flora and Fauna of the San Francisco valley and its surroundings (Estación Científica San Francisco), Southern Ecuador. Ecotropical Monographs 4, pp. 15-58.

Homeier, J., Werner, F.A., Gradstein, S.R., Breckle, S.-W., Richter, M., 2008. Potential vegetation and floristic composition of Andean forests in South Ecuador, with a focus on the RBSF. In: Beck, E., Bendix, J., Kottke, I., Makeschin, F., Mosandl, R. (Eds.), Gradients in a Tropical Mountain Ecosystem of Ecuador. Ecological Studies 198. Springer, Berlin, Heidelberg, pp. 87-100. 
Niemann, H., Brunschön, C., Behling, H., 2010. Vegetation/modern pollen rain relationship along an altitudinal transect between 1920 and $3185 \mathrm{~m}$ a.s.l. in the Podocarpus National Park region, southeastern Ecuadorian Andes. Review of Palaeobotany and Palynology 159, 69-80.

Odgaard, B.V., 1994. The Holocene vegetation history of northern West Jutland, Denmark. Opera Botanica 123, 1-171.

Odgaard, B.V., 1999. Fossil pollen as a record of past biodiversity. Journal of Biogeography 26, 7-17.

Odgaard, B.V., 2001. Palaeoecological perspectives on pattern and process in plant diversity and distribution adjustments: a comment on recent developments. Diversity and Distributions 7, 197-201.

Peros, M.C., Gajewski, K., 2008. Testing the reliability of pollen-based diversity estimates. Journal of Paleolimnology 40, 357-368.

Richter, M., Diertl. K.-H., Emck, P., Peters, T., Beck, E., 2009. Reasons for an outstanding plant diversity in the tropical Andes of Southern Ecuador. Landscape Online 12, 1-35.

Seppä, H., 1998. Postglacial trends in palynological richness in the northern Fennoscandian tree-line area and their ecological interpretation. The Holocene 8, 43-53.

Weng, C., Hooghiemstra, H., Duivenvoorden, J.F., 2006. Challenges in estimating past plant diversity from fossil pollen data: statistical assessment, problems and possible solutions. Diversity and Distributions 12, 310-218.

Weng, C., Hooghiemstra, H., Duivenvoorden, J.F., 2007: Response of pollen diversity to the climate-driven altitudinal shift of vegetation in the Colombian Andes. Philosophical Transactions of the Royal Society of London - Biological Sciences 362, 253-262.

Willis, K.J., Araújo, M.B., Bennett, K.D., Figueroa-Rangel, B., Froyd, C.A., Myers, N., 2007. How can a knowledge of the past help to conserve the future? Biodiversity conservation and the relevance of long-term ecological studies. Philosophical Transactions of the Royal Society of London - Biological Sciences 362, 175-186. 



\section{Chapter 7 .}

\section{Synthesis}

\section{Research outcomes}

All studies presented within the previous chapters of this dissertation contribute to a better understanding and an increase in knowledge of late Quaternary palaeoenvironmental conditions in the southeastern Ecuadorian Andes and the Podocarpus National Park (PNP) area situated within the region of the Andean depression. New palynological data and research approaches provide important insights into and conclusions for the three main research topics introduced in chapter 1 and summarized below.

\section{(1) Past vegetation, climate and fire dynamics at key sites in the PNP area}

Analysis of the Laguna Campana record, which is located on the western slopes at $2488 \mathrm{~m}$ a.s.l. near the northwestern PNP limits, yielded a detailed environmental reconstruction for the study site over the past ca. 500 years (chapter 3). The small lake originated from a landslide, which might have been promoted by human activities and occurred at ca. A.D. 1470. Evidence of anthropogenic impact was seen in the increasing deposition of atmospherically derived lead since the formation of the lake. Humans continuously affected local vegetation development and biodiversity through slash and burn cultivation, pasture and deforestation. The most serious consequences of anthropogenic interferences were recorded since ca. A.D. 1980. Therefore, a dense mountain rainforest, which would otherwise be the natural vegetation at the study site, could not develop. The current vegetation structure and the diminished biodiversity as compared to natural conditions have been present at the study site since the recorded time period. Hydrological variations, likely caused by changes in precipitation, affected riparian vegetation without influencing vegetation at greater distances away from the lake.

Two pollen records derived from the Cerro Toledo area at 3150 and $3110 \mathrm{~m}$ a.s.l. provided the initial palaeoecological data for the southern PNP region (chapter 2). Palynological results date back ca. 20,000 years to late Pleistocene times and indicate that páramo vegetation with high occurrence of Plantago rigida characterized the last glacial maximum (LGM), reflecting cold and wet conditions. Mountain rainforests likely occupied markedly lower elevations than at present, but glaciers did not cover the southern PNP at least since the LGM period. By means of slightly rising temperatures since late glacial times, mountain rainforest developed and shifted upslope, thus repressing páramo vegetation. The transition to the Holocene witnessed a grad- 
ual change towards warmer climatic conditions with temperatures peaking in early Holocene times. Subsequently páramo vegetation re-expanded with the dominance of Poaceae, thus suggesting a change to cooler conditions. The present peat bog began to develop in mid-Holocene times. During the late Holocene, decreasing páramo vegetation suggests a change to warmer conditions. Indications of anthropogenic disturbance are found since ca. 2300 cal yr BP, but the study site was comparatively little affected by humans. Continuous and very humid conditions led to the conclusion that vegetation development in the PNP area was principally influenced by the conditions and climates of the Amazon basin to the east. In contrast to previous studies at El Tiro site in the northwestern PNP region, it appears that Andean barriers for climatic conditions and upslope moving taxa from the Amazon basin are less effective in the southern PNP area.

(2) Reconstruction and visualization of vegetation dynamics in the PNP area since the late Pleistocene on a regional scale

Integrating much of the palaeoecological data thus far obtained in the PNP area into a regional environmental reconstruction, which includes a visualization of overall vegetation dynamics since the LGM, permits a comprehensive interpretation of the fossil pollen data (chapter 4). To address the former studies' uncertainties of past altitudinal ranges of vegetation and upper forest line (UFL) shifts a rule of thumb for vertical UFL shifts was developed using arboreal pollen percentages. The environmental reconstruction showed that the UFL position during the LGM was at least ca. $700 \mathrm{~m}$ lower in the northernmost part of the PNP area and ca. $250 \mathrm{~m}$ further south, where the influence of the eastern Amazon basin is greater. During this time, forest extended up to elevations of ca. 2100-2800 m a.s.l. and páramo vegetation widely dominated the landscape. Lower margins of terminal moraines were estimated at ca. $3200 \mathrm{~m}$ a.s.l., and only the central PNP was covered by glaciers during the LGM. Due to rising temperatures since late glacial times, deglaciation concluded with the beginning of the Holocene, and forest shifted gradually upslope. However, local differences in vegetation composition, climatic conditions and human disturbance regimes caused site-specific vegetation development in the PNP area. In the southern and probably also in the central part of the PNP, mountain forest and the UFL already began to advance during late glacial times, whereas forest advances in the northernmost part of the PNP, near El Tiro site, were not recorded prior to the onset of the Holocene. During initial times of the Holocene and mid-Holocene times, forest in the central and southern PNP area probably occurred at slightly higher elevations than are seen at present $(50-200 \mathrm{~m})$. On the other hand, forests probably never reached higher elevations than today's levels in the northernmost part of the PNP. Fires, most likely of anthropogenic origin, were recorded from early to late Holocene times. They occurred at the study sites during different times and with various intensities. Past fires influenced local vegetation composition as well as páramo and forest expansion. However, fire was rarely responsible for extensive forest destruction. Nevertheless, certain taxa, e.g. Weinmannia or Myrica, were seriously affected by fire. In regional comparison, UFL changes estimated for the PNP area are less extensive than other 
known estimates for sites outside the Andean depression region. This may be a result of generally lower mountain ranges, relatively wet climatic conditions, and different and diverse vegetation patterns within the Andean depression. In the Andean depression region, including the PNP, temperature seems to be less important for the UFL and vegetation changes than in other regions of the northern Andes. Instead we assume that other drivers, e.g. precipitation and wind, may be much more important for the developments in our study region. Additionally, the species-rich polytypic UFL in this region most likely causes enhanced variety in the response of vegetation to climatic changes and possibly less extensive shifts of forest as compared to the monotypic UFL in other parts of the Andes.

(3) Relationship between modern pollen rain data and present vegetation/plant diversity patterns

A previous analysis of the relationship between modern vegetation and pollen rain data along an altitudinal gradient in the Reserva Biológica San Francisco, which is located in northern PNP area, was improved by the use of new statistical approaches (chapter 5). Data analysis revealed that the altitudinal distribution of present vegetation types and certain plant taxa as well as the present UFL position are well reflected in the modern pollen rain data. Several pollen and spore taxa were identified to be specific for one of the present vegetation types. However, pollen and spore taxa distributions not representative of modern vegetation patterns were also found. Wide distribution of several plants and an extended upslope dispersal of pollen of anemophilous plants, due to dominant easterly winds in the study region, are supposed to be responsible for the discrepancies. Hence, the overrepresentation of certain pollen taxa at high elevations (e.g. Moraceae/Urticaceae) and at almost every altitude has to be interpreted with caution. Nevertheless, outcomes of this analysis should be interpreted as previous results, which need further verification.

The same modern pollen and vegetation data (see above) were used for a supplementary study to determine how the vegetation diversity of the highly diverse RBSF is represented in the recorded diversity of pollen and spore taxa (palynological richness) and of plants (chapter 6). For the study area it was shown that the general trend of decreasing diversity with increasing elevation was well reflected by the plant species richness observed in vegetation plots. Pollen data did not reveal a significant relationship between palynological richness and altitude along the entire gradient, but a certain similarity between patterns of palynological richness and plant diversity is indicated. However, due to variable pollen source areas within the different vegetation structures, palynological richness reflects diversity of different area sizes, whereas plant species richness represents diversity in same sized vegetation plots. This circumstance and other factors influence palynological richness and probably cause less distinct diversity patterns within the pollen data than within plant data. Hence, using palynological richness as measure for vegetation diversity is complex, and special caution is recommended when interpreting biodiversity changes in a time series approach for highly diverse areas such as the RBSF. Ample pre-examination may be necessary. The data set used in this study is not sufficient for a precise anal- 
ysis of the relationship between pollen and plant diversity. Only vague indications can be outlined at this point, and a better data basis is needed to be able to draw final conclusions.

\section{Concluding remarks and perspectives}

On the basis of the Laguna Campana record (chapter 3) it was shown that continuous and pervasive human impact seriously affects vegetation patterns and leads to decreased biodiversity levels and local forest destruction. Over longer time periods, however, observed vegetation changes are not solely caused by human impact and disturbance regimes. Especially during times with less or without human activity, climatic conditions controlled vegetation development (chapter 2 and 4). Upslope shifts of the UFL, as a result of rising temperatures, were recorded since late glacial times and since the beginning of the Holocene. Climate changes also caused compositional changes of vegetation. It was shown that fires, most likely of anthropogenic origin, and climate caused changes in the distribution and composition of páramo and forest. Hence, present vegetation structure and biodiversity in the PNP area developed under both natural climatic dynamics and human introduced landscape changes, the latter showing increased incidence during mid- to late Holocene times.

Even though palaeoecological conditions of the PNP area share some overall similarities with the northern Andes of Peru, Colombia and Ecuador (chapter 2-4), local differences in natural and anthropogenic environmental changes have to be considered as reasons for varying ecosystem responses. The high complexity and heterogeneity of Andean habitats, as well as site-specific relevance and interactions of multitude factors determining vegetation patterns, are responsible for the observed differences in local conditions. In particular, the Andean depression region of the southeastern Ecuadorian Andes holds special characteristics (e.g. the highly variable, species-rich and comparatively low UFL and very humid climatic conditions) in this context and contribute to differences found both in the past and present.

All of the facts mentioned above are of major importance for conservation concerns and management strategies in the area of the PNP as part of the global biodiversity hotspot of the tropical Andes. If conservation aims at preserving natural vegetation patterns, then natural and original positions of the UFL should be conserved. In this context, relatively low altitudes and differences in the position of the UFL in the southeastern Andes of Ecuador have to be considered. This study suggests that within the wider PNP area, forest patches found at distances greater than $200 \mathrm{~m}$ above the actual UFL may have never been connected to closed forest. Páramo situated at relatively low elevations, where strong human impact did not occur in the past and is currently not observed, is natural and worthy of protection. However, the high diverse and heterogeneous environment we found here requires local investigations and does not allow the realization of generalized actions on a regional scale.

This study and former investigations supports the idea that observed changes in distribution and composition of the vegetation in response to past climatic changes may improve the predictions about feared ecosystem changes under future global 
change. However, whether certain tree species or mountain rainforests shift upslope and replace páramo (taxa) due to predicted increasing temperatures in the study area depends on various factors within this climatically heterogeneous region. Future investigations ought to address how diversity developed in the studied hotspot and how future climate changes will affect this diversity (see chapter 6). In this context, a current research approach intends to identify past dynamics of plant diversity and the respective factors leading to diversity levels.

Future investigations certainly should focus on the amplification of modern pollen deposition studies to support initial results of the relationship between modern pollen rain data and vegetation and diversity patterns (chapter 5 and 6 ). This would improve the basis for data interpretation, especially in terms of the estimation on altitudinal ranges of UFL shifts (chapter 4) and the change in diversity throughout time.

Drawing further conclusions on this highly complex and diverse study region requires more palaeoecological data than gathered until now. New investigations should concentrate on sites in the lower eastern part and the drier western side of the PNP region, where palynological evidence of the local and regional environmental history is insufficient or absent. Additional studies within the Andean depression would enhance the understanding of the regional development within this delimited area. Moreover, new pollen records will improve the present regional reconstruction and visualization of palaeoenvironments in the PNP area and thus enlarge the scope of application. Investigations aimed at this goal are already underway and include the development of a 3D-landscape model (PODOLAND) that integrates biotic and abiotic factors of the study region with modern and past landscape data. The visualization and landscape modeling of past environmental changes will provide interdisciplinary specialists outside the palynological community with greater access to long-term temporal palaeoecological information. 



\section{Appendix A. \\ Identified pollen and spores of the Cerro Toledo (CT/CTB) and Laguna Campana (LC) records - complete list and photos}

Remarks:

- Morphological descriptions of pollen and spore types: Hooghiemstra (1984) Niemann (2008) $)^{2}$, own descriptions

- Picture sources: mainly own photographs, Niemann $(2008)^{2}$

- Note: size indications of pollen and spores are listed, scale bar $(10 \mu \mathrm{m})$ is not available for each picture

- Database serial no.:

refers to the the "Ecuadorian Pollen Key" database, amplified within this dissertation (kept at the University of Göttingen)

- Abbreviations for the vegetation types: LMF - lower mountain forest, UMF - upper mountain forest, SUB - subpáramo, PAR - páramo, SDF - semideciduous interandean forest

\footnotetext{
${ }^{1}$ Hooghiemstra H., 1984. Vegetation and climatic history of the High Plain of Bogota, Colombia: a continuous record of the last 3,5 million years. Dissertationes Botanicae 79, Cramer, Vaduz, $368 \mathrm{pp}$.

2 Niemann, H., 2008. Late Quaternary vegetation, climate and fire dynamics in the Podocarpus National Park region, southeastern Ecuadorian Andes. Dissertation, University of Göttingen, Germany, 178 pp.
} 


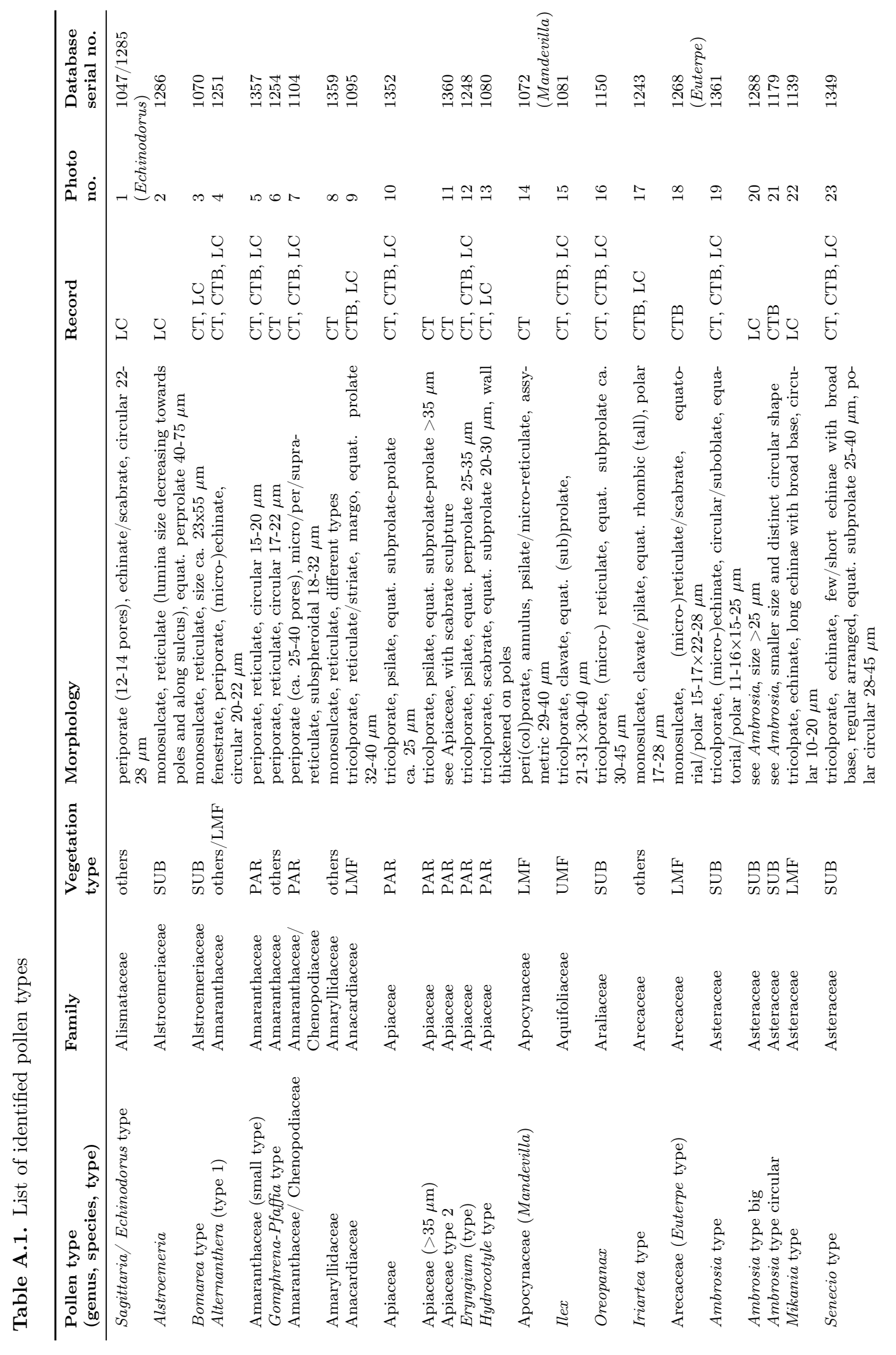




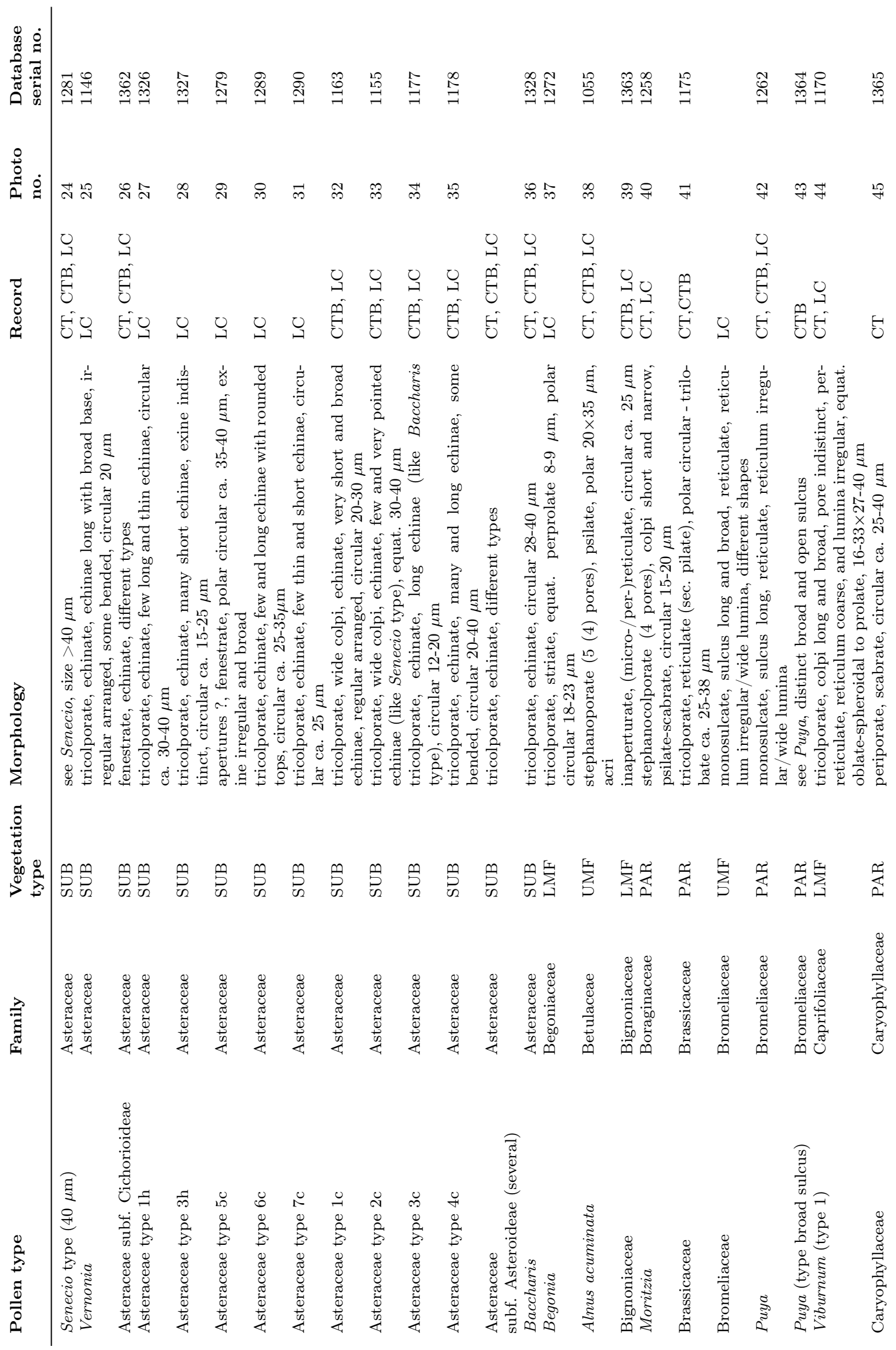




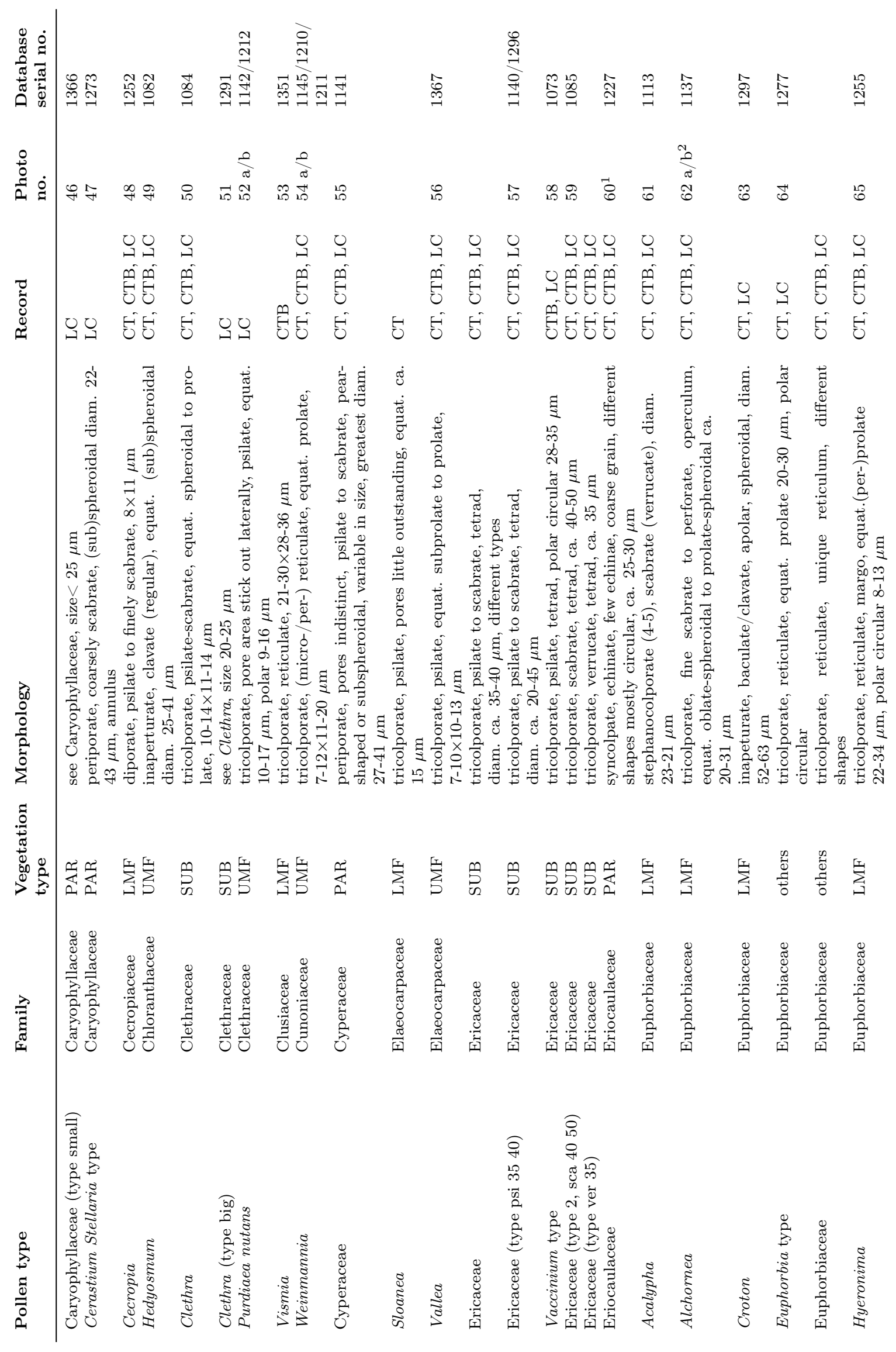




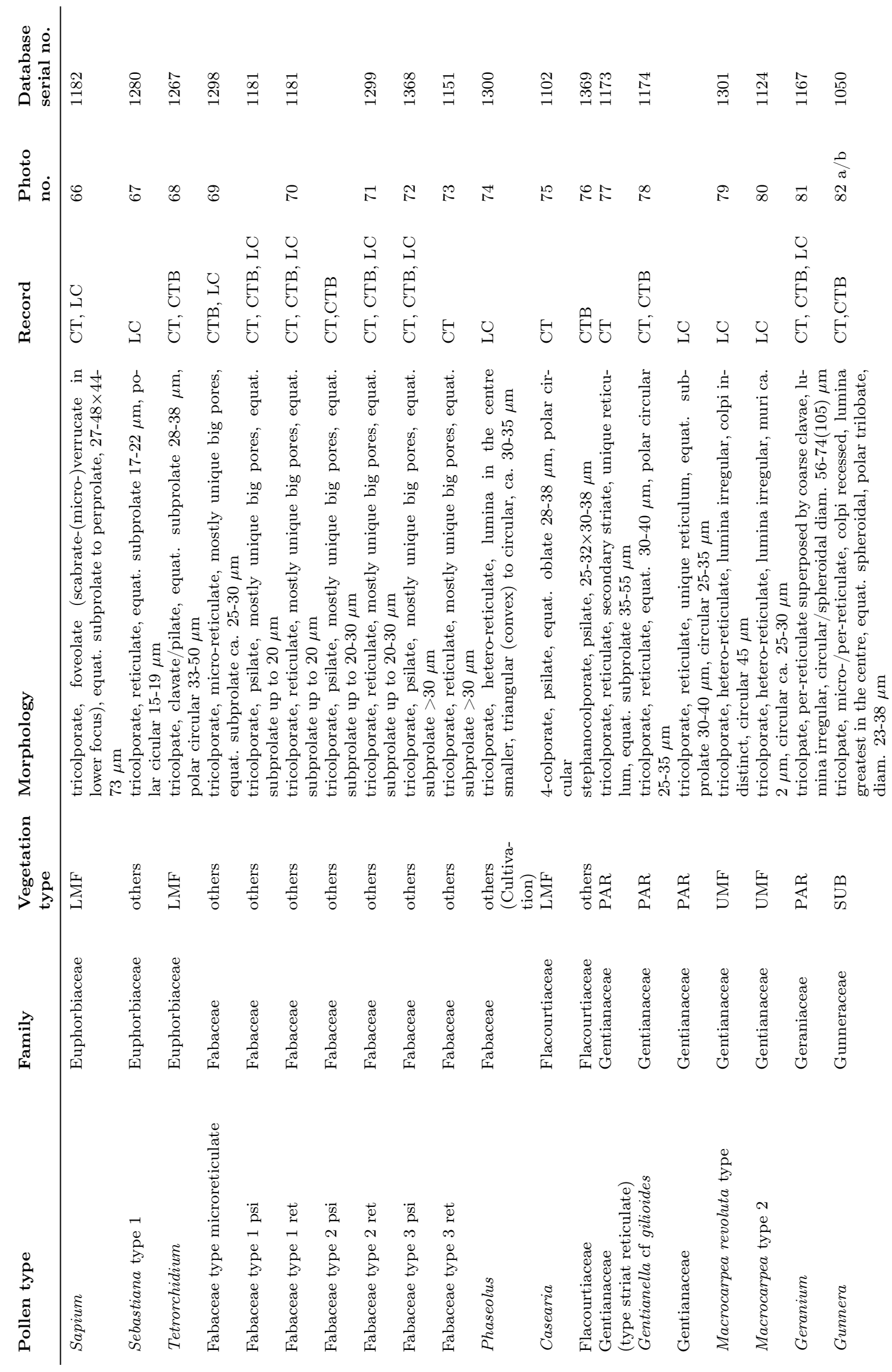




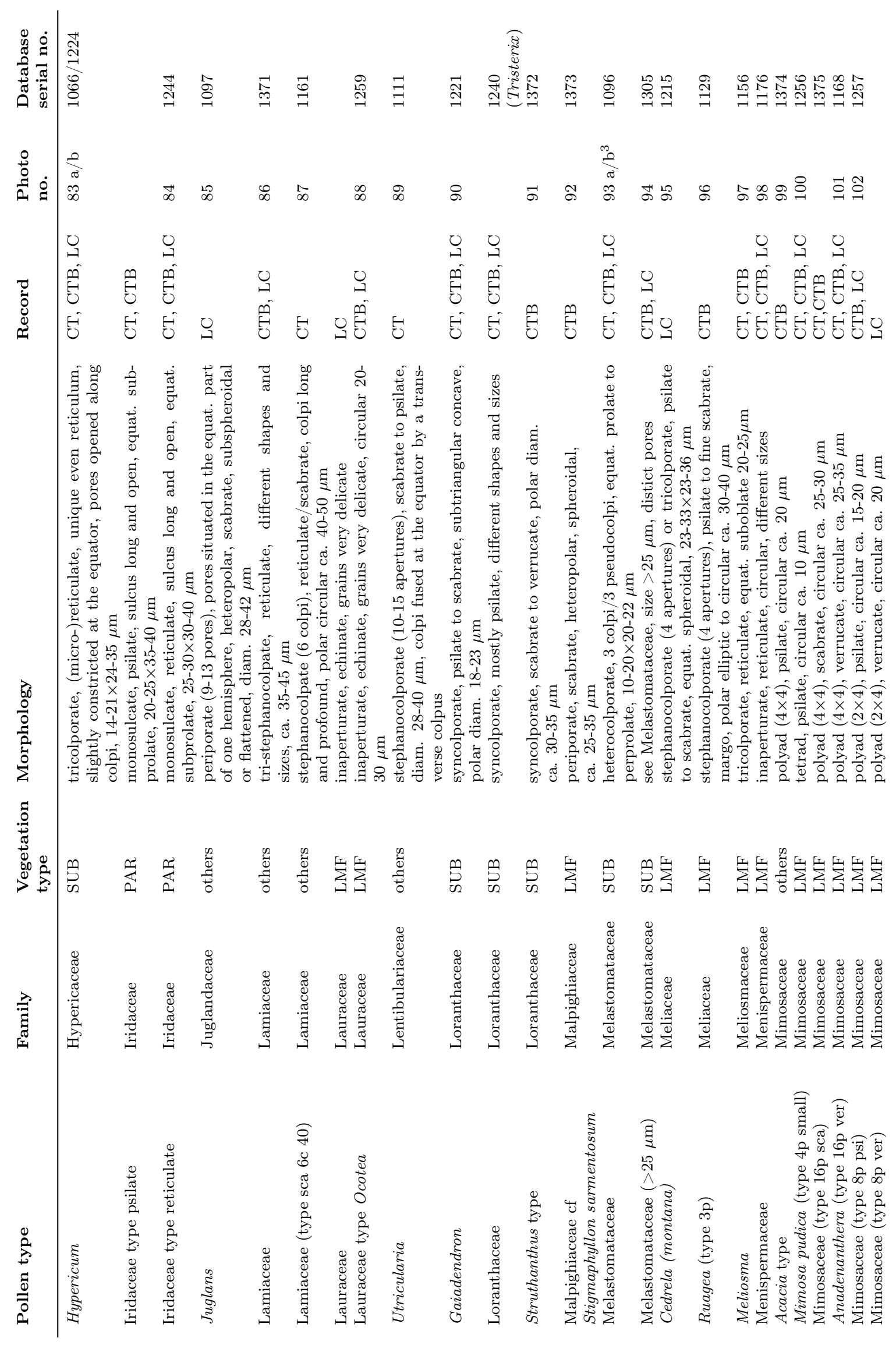




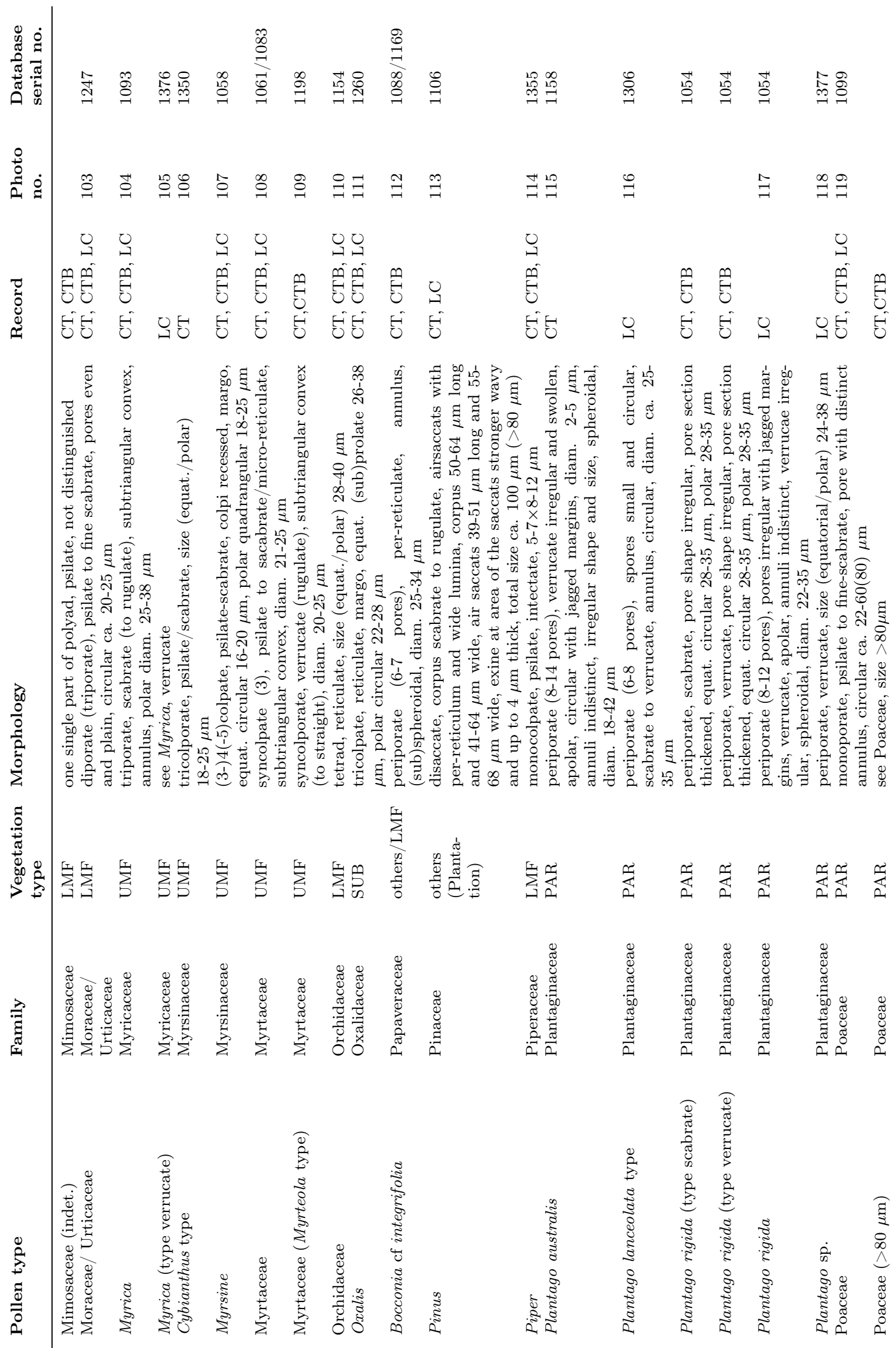




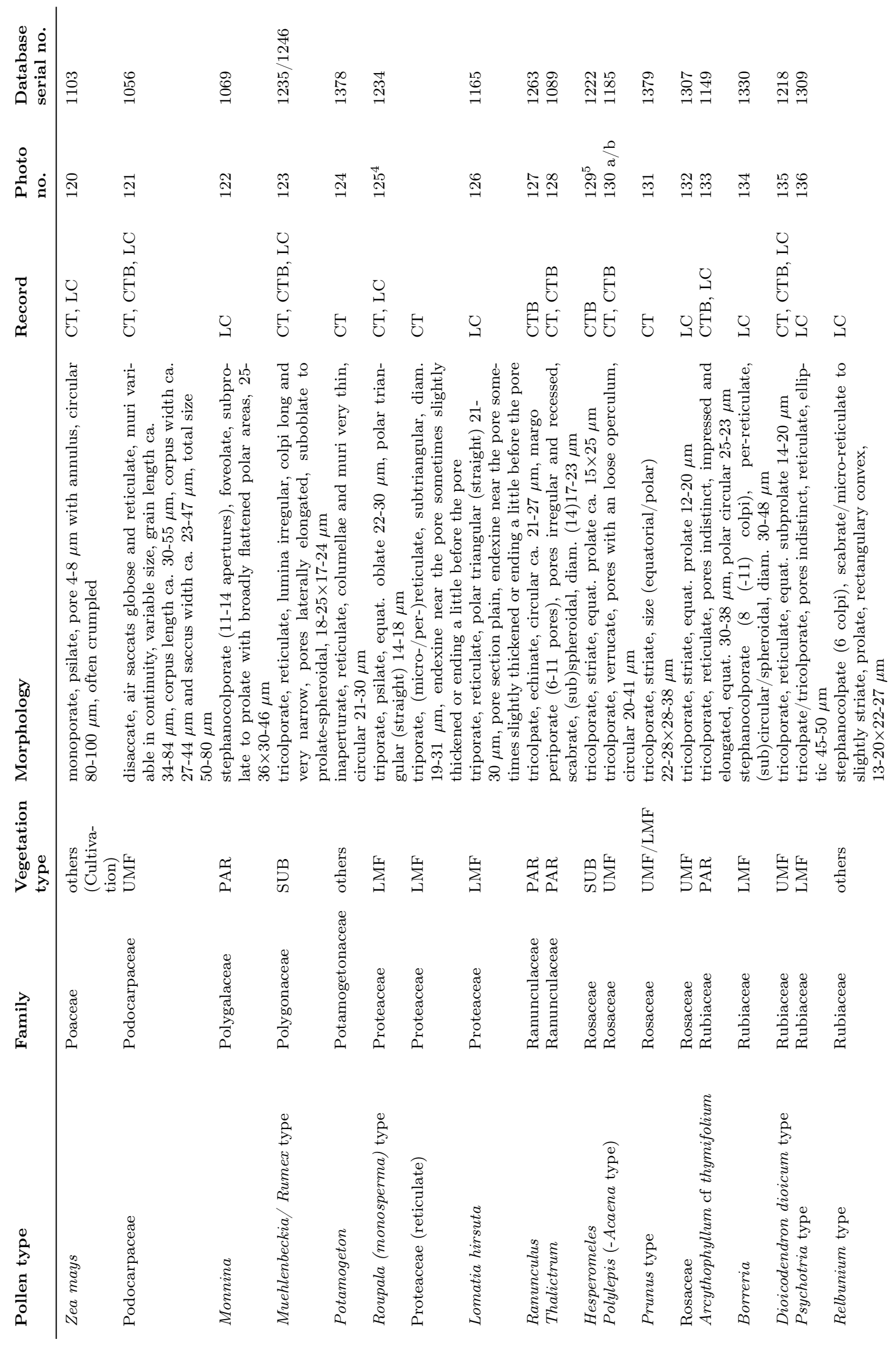




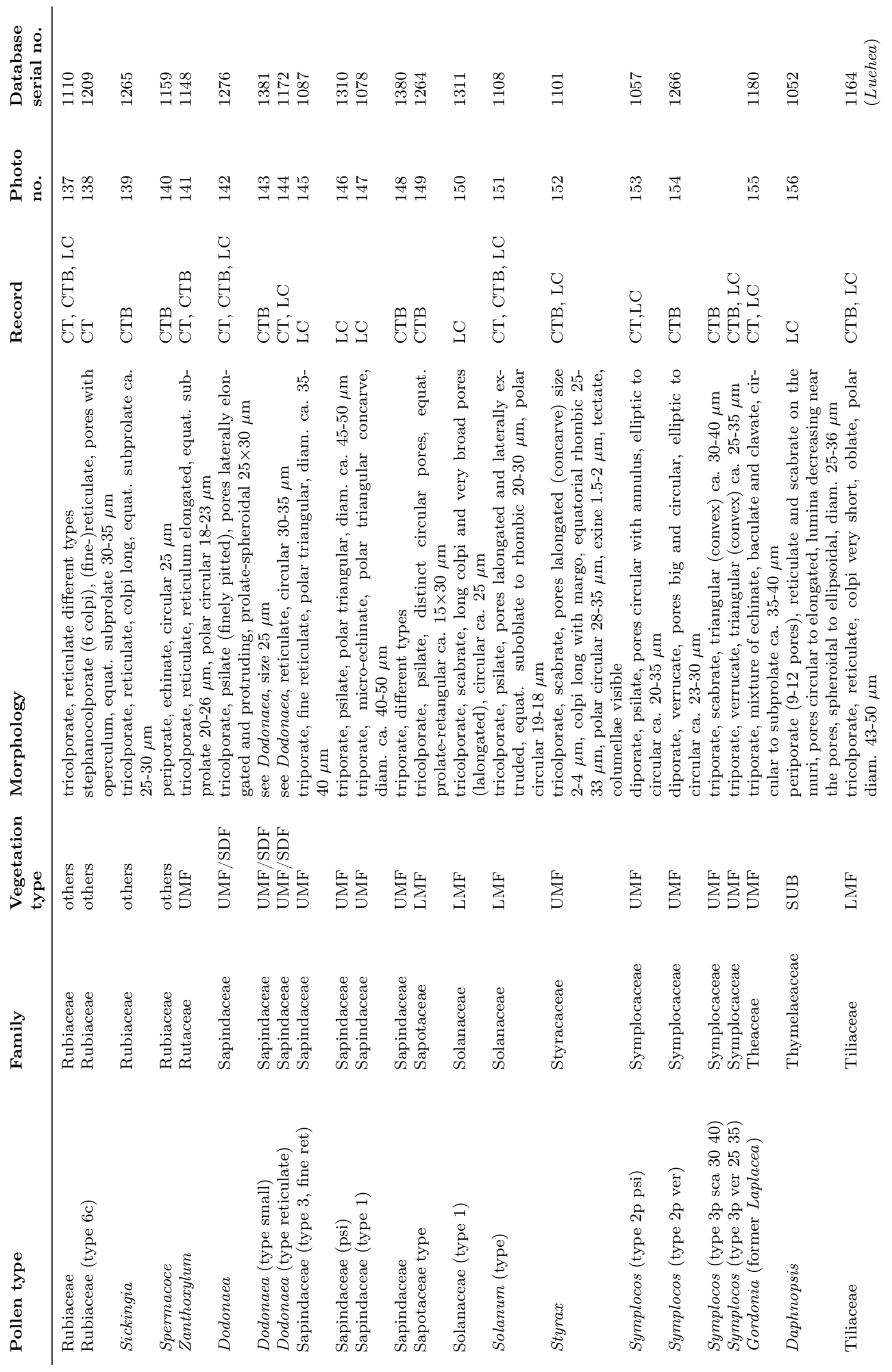




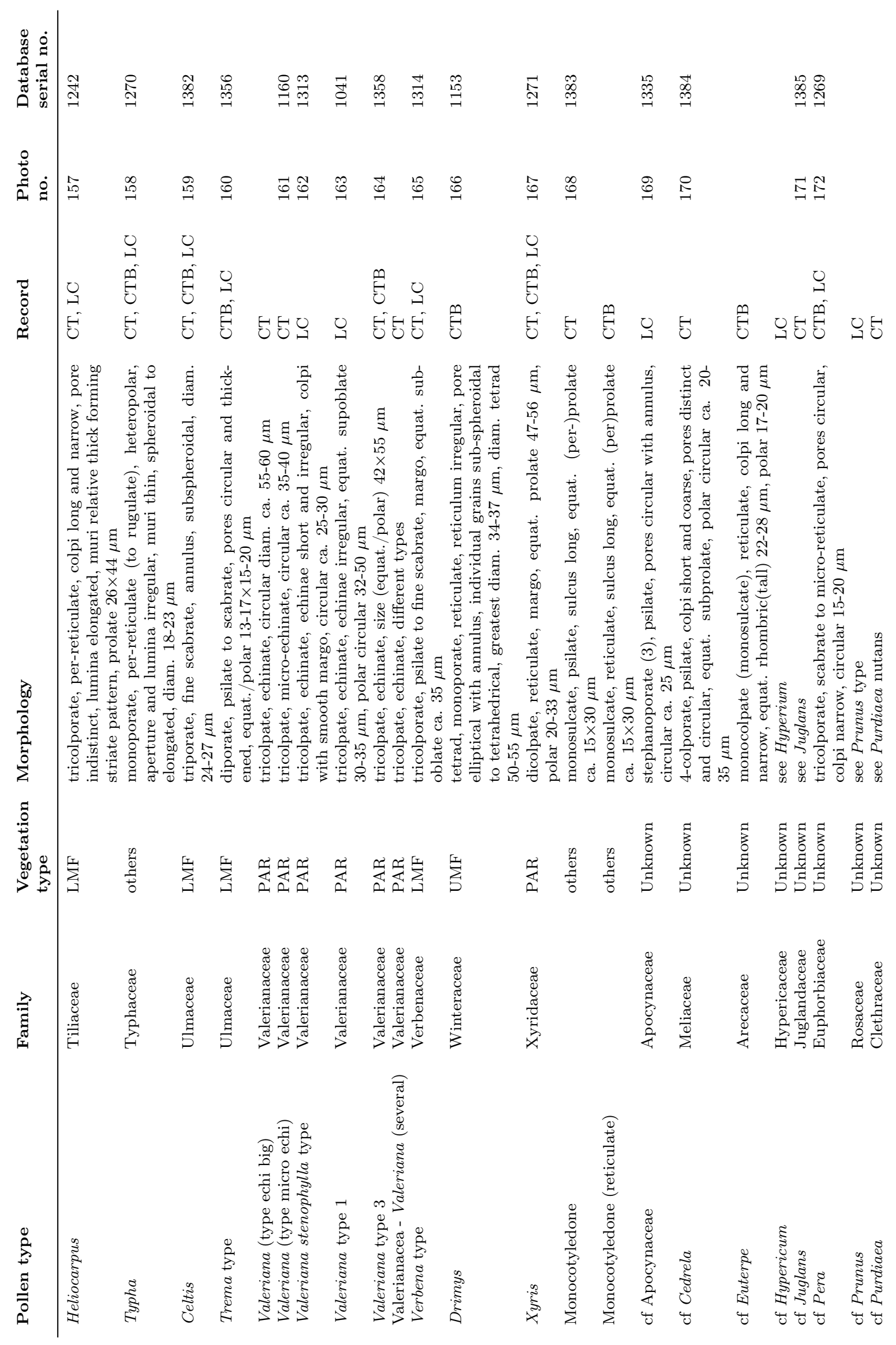




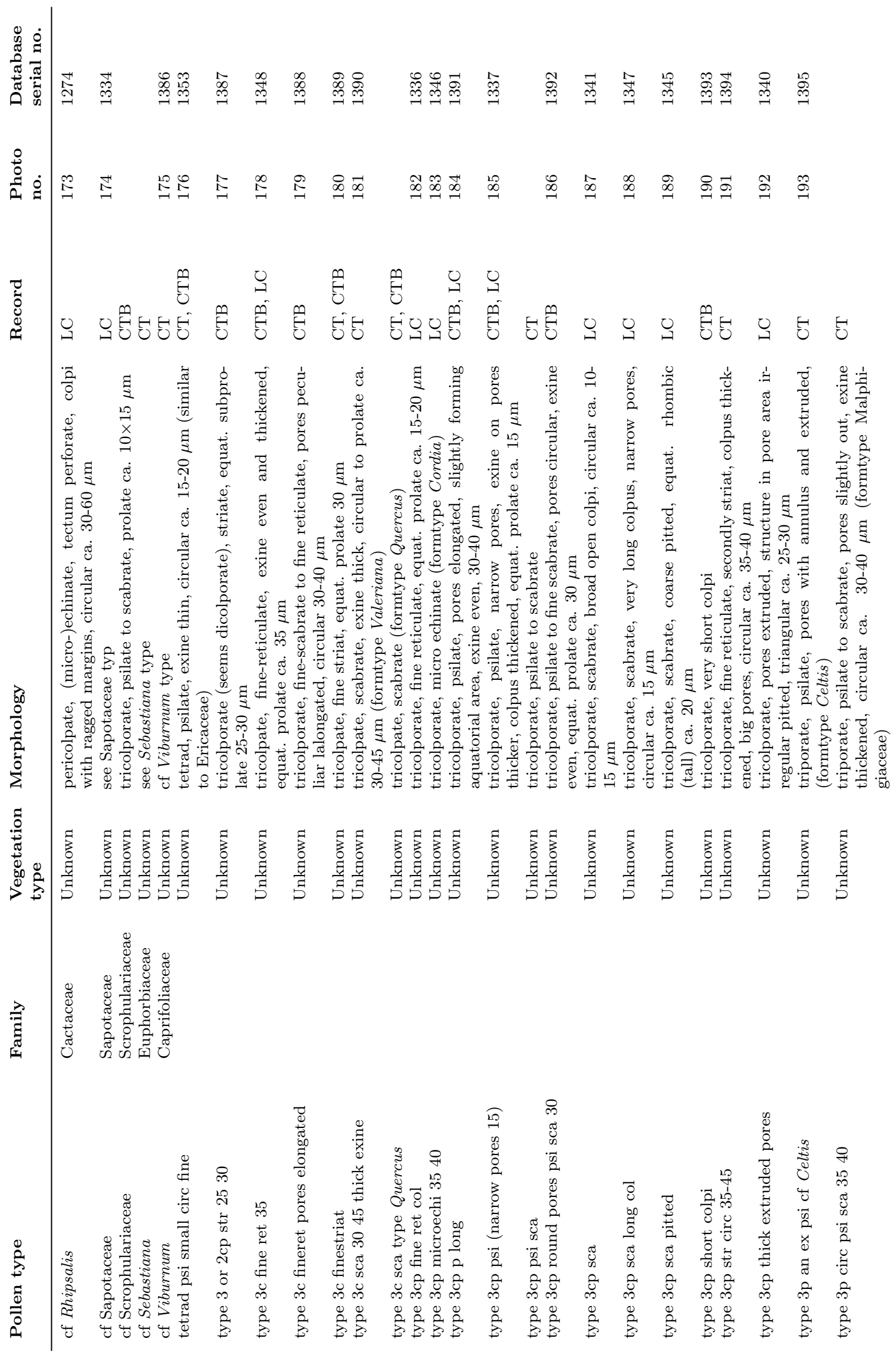




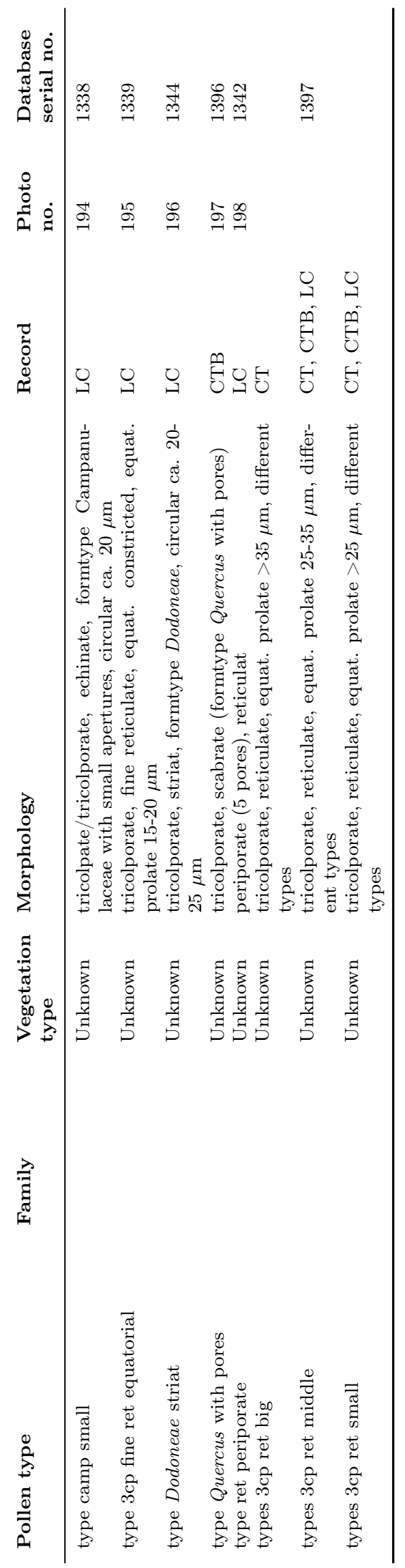


Pollen plate 1

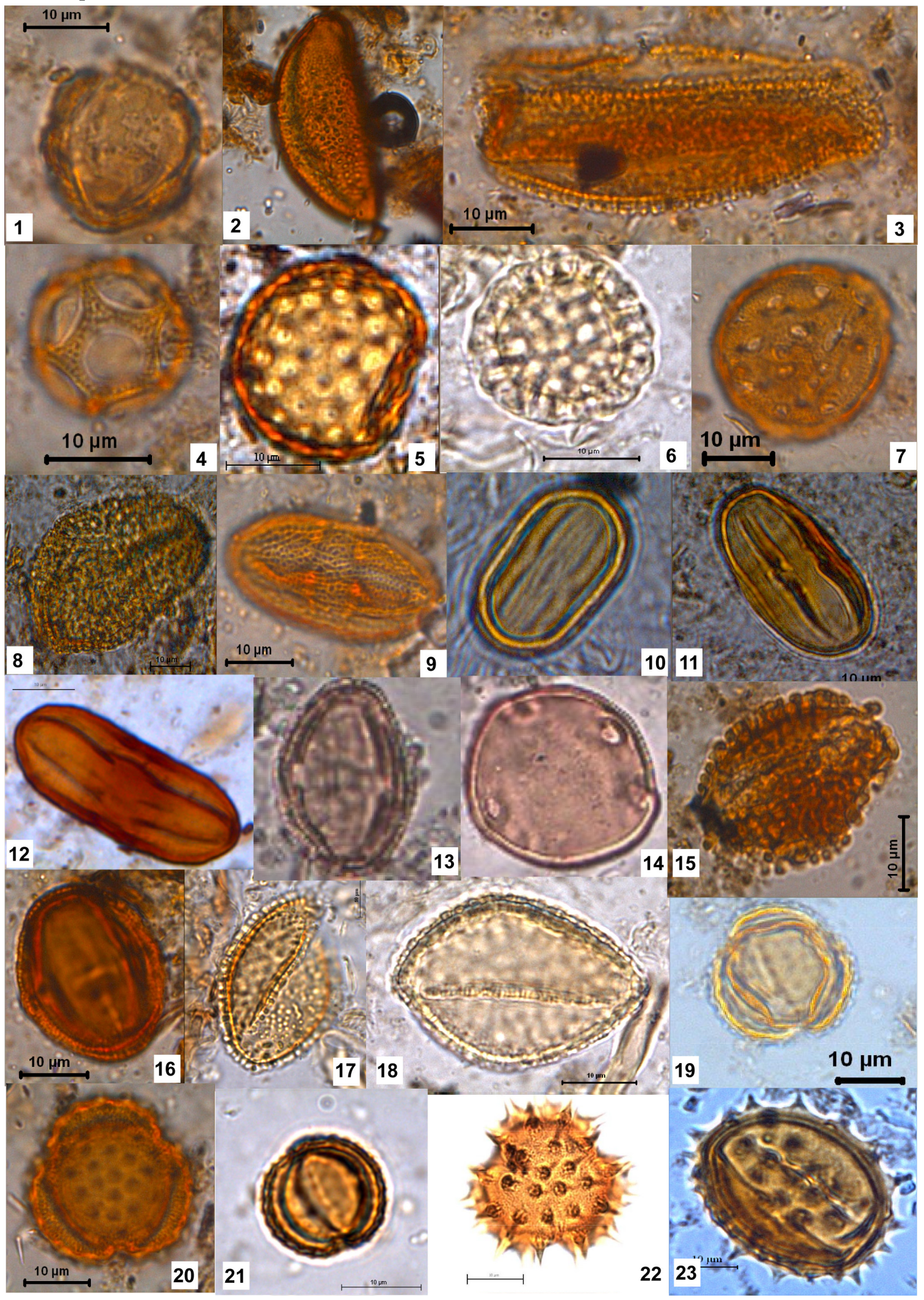


Pollen plate 2

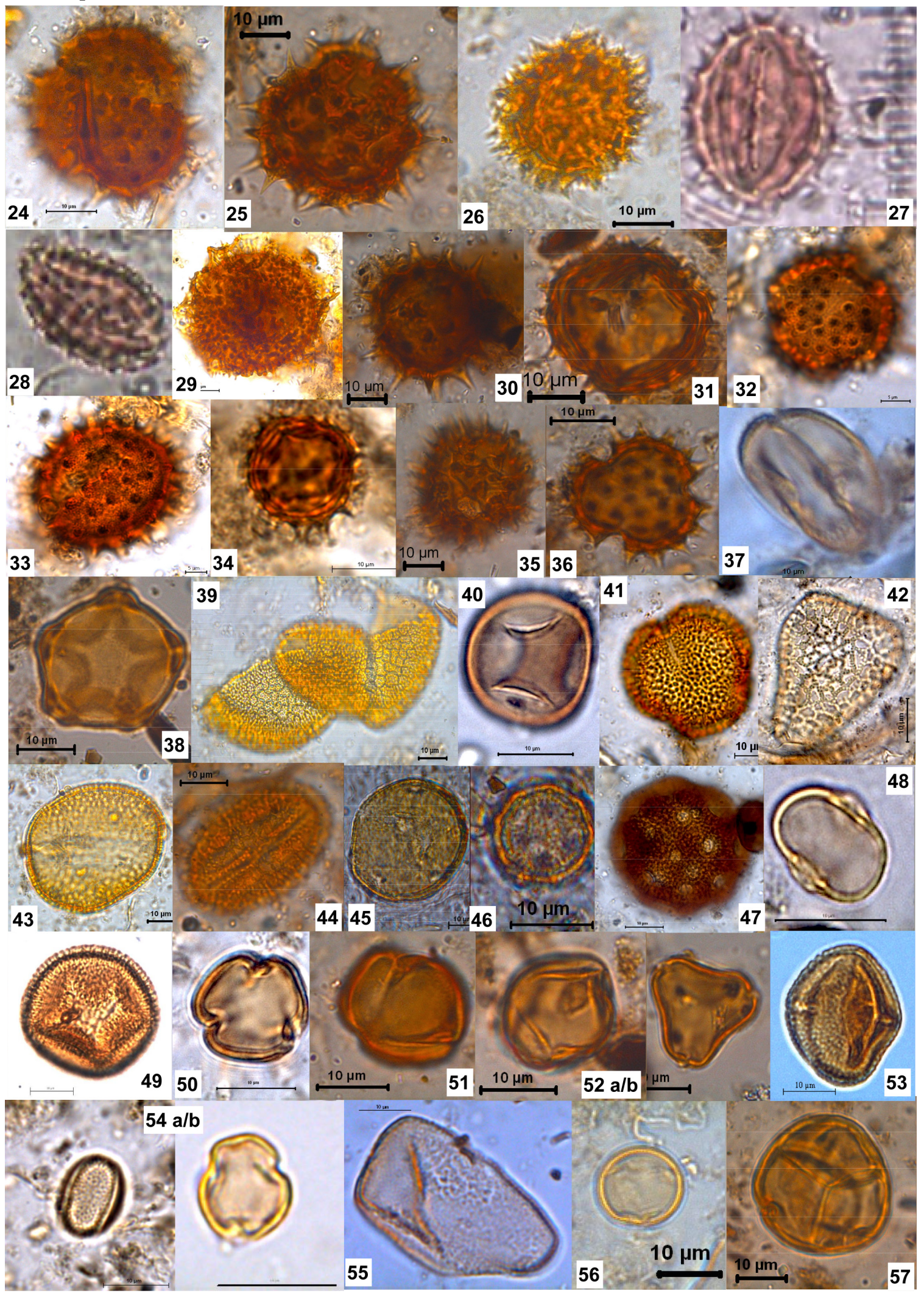


Pollen plate 3

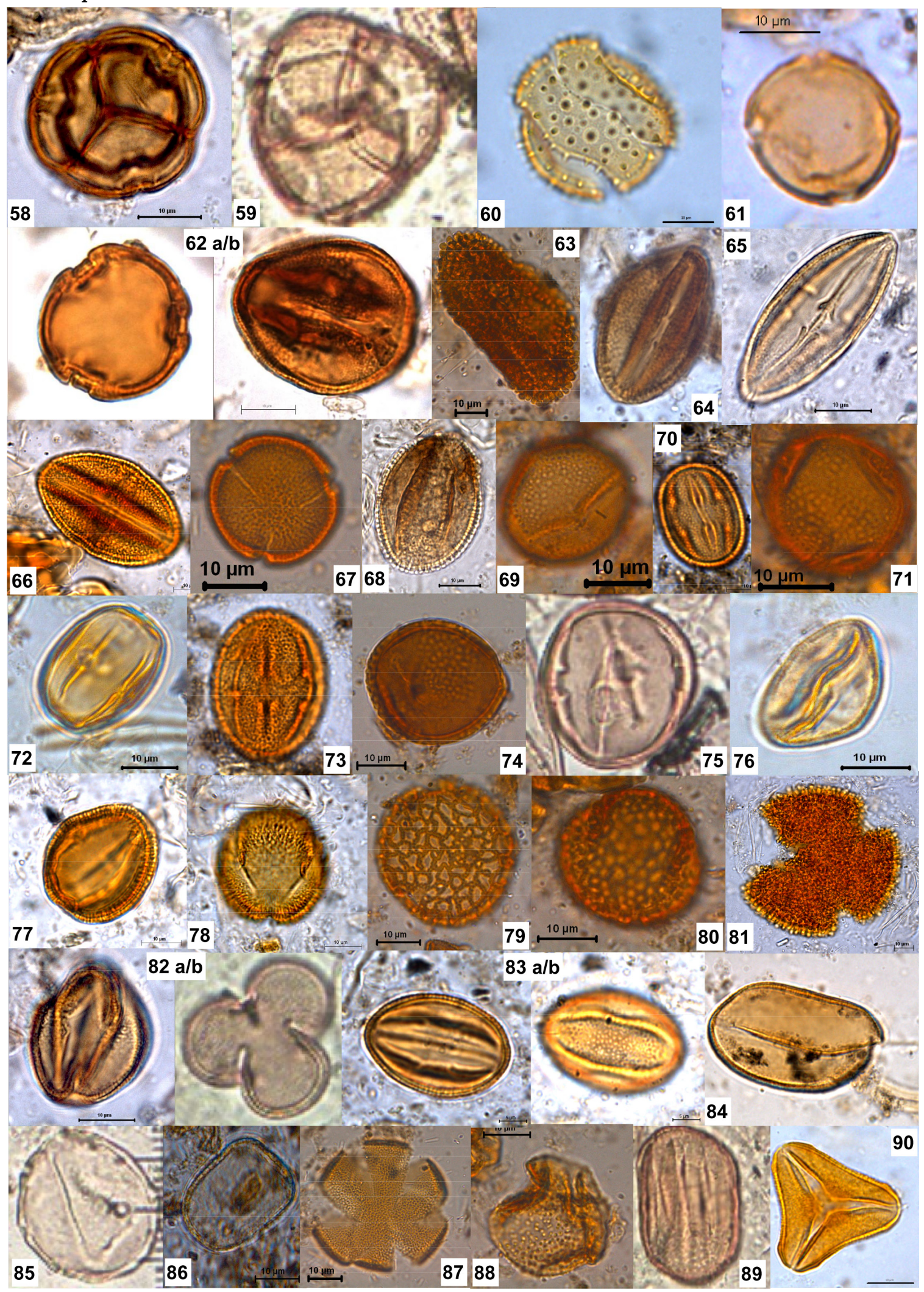


Pollen plate 4

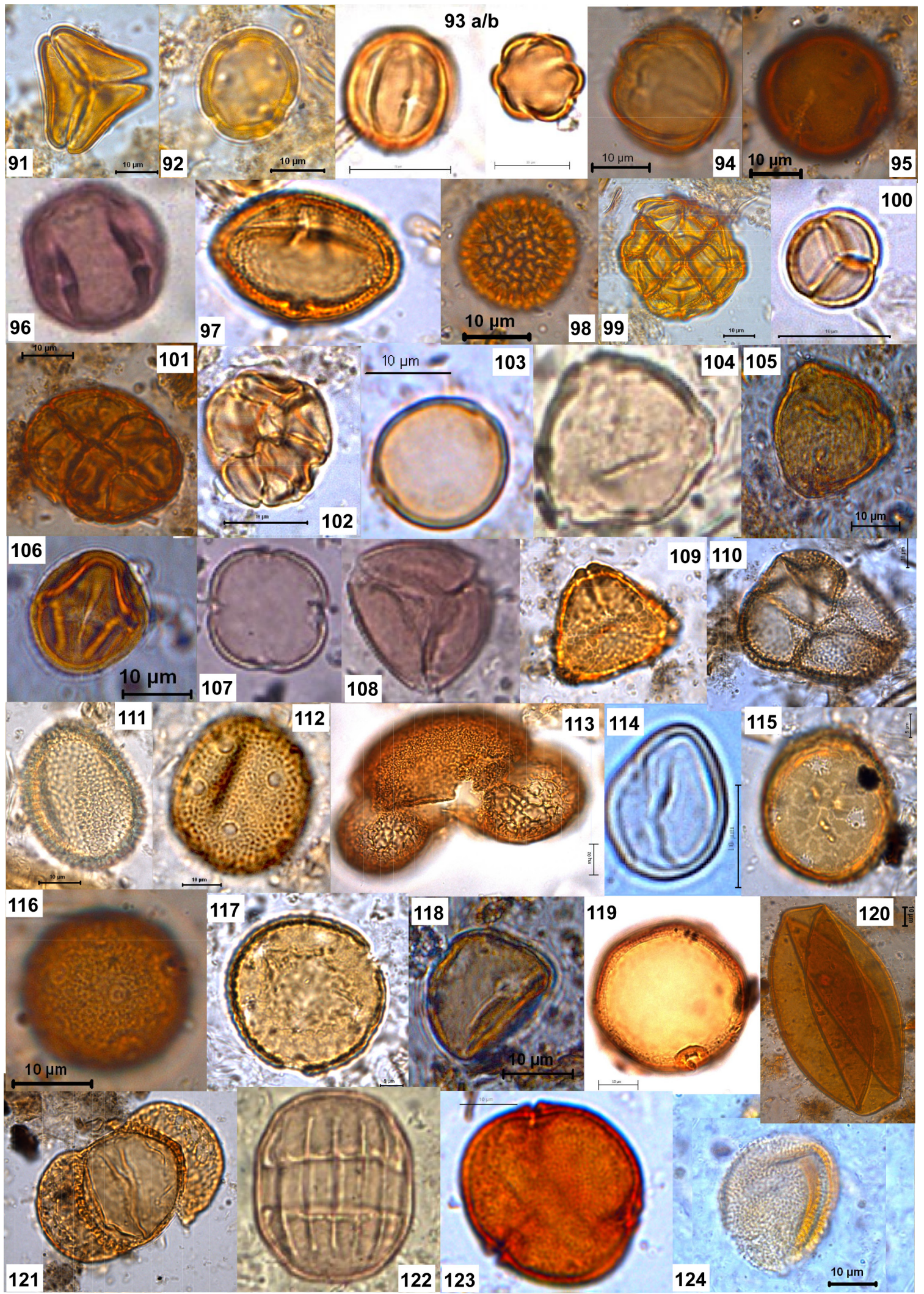


Pollen plate 5

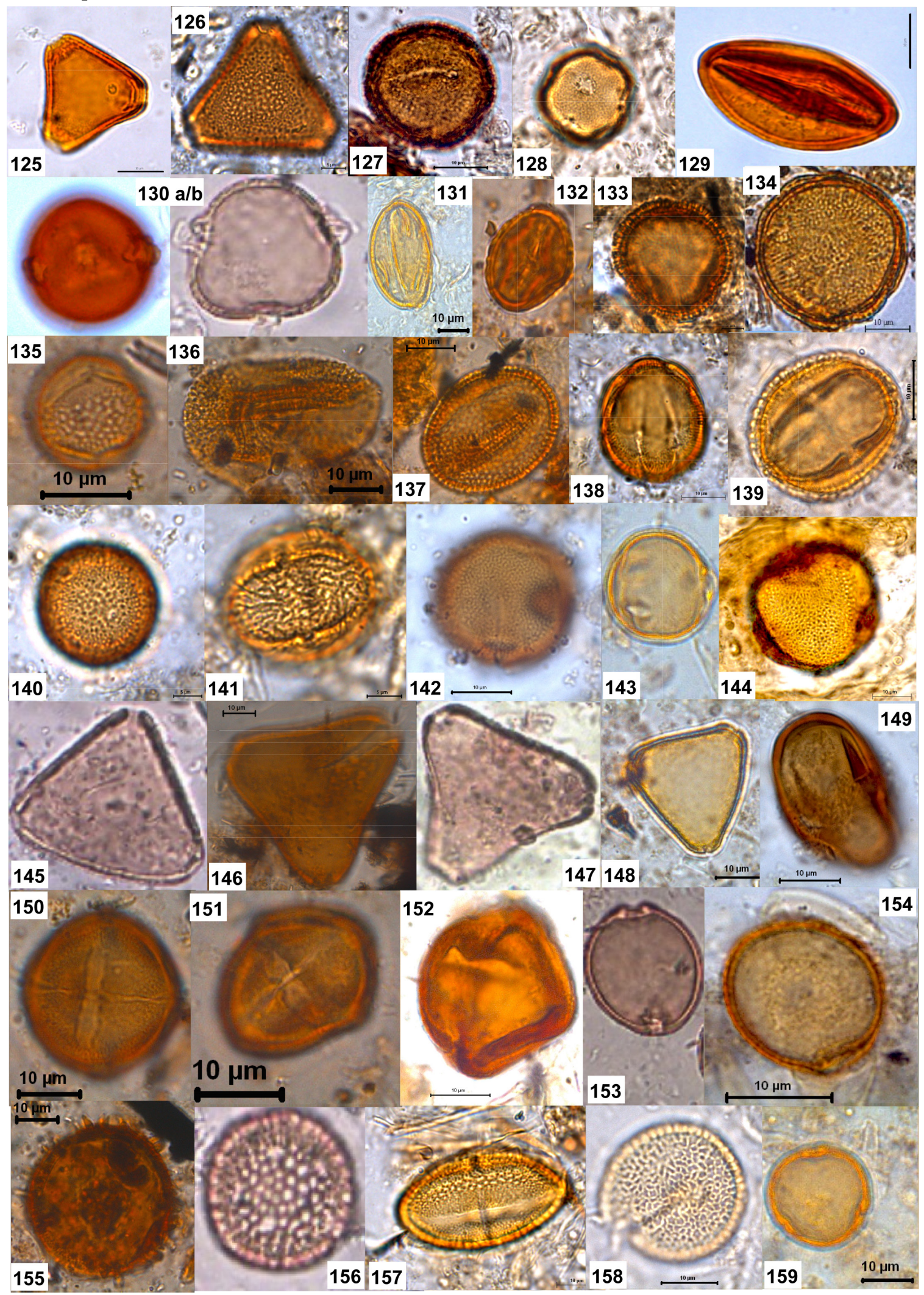


Pollen plate 6

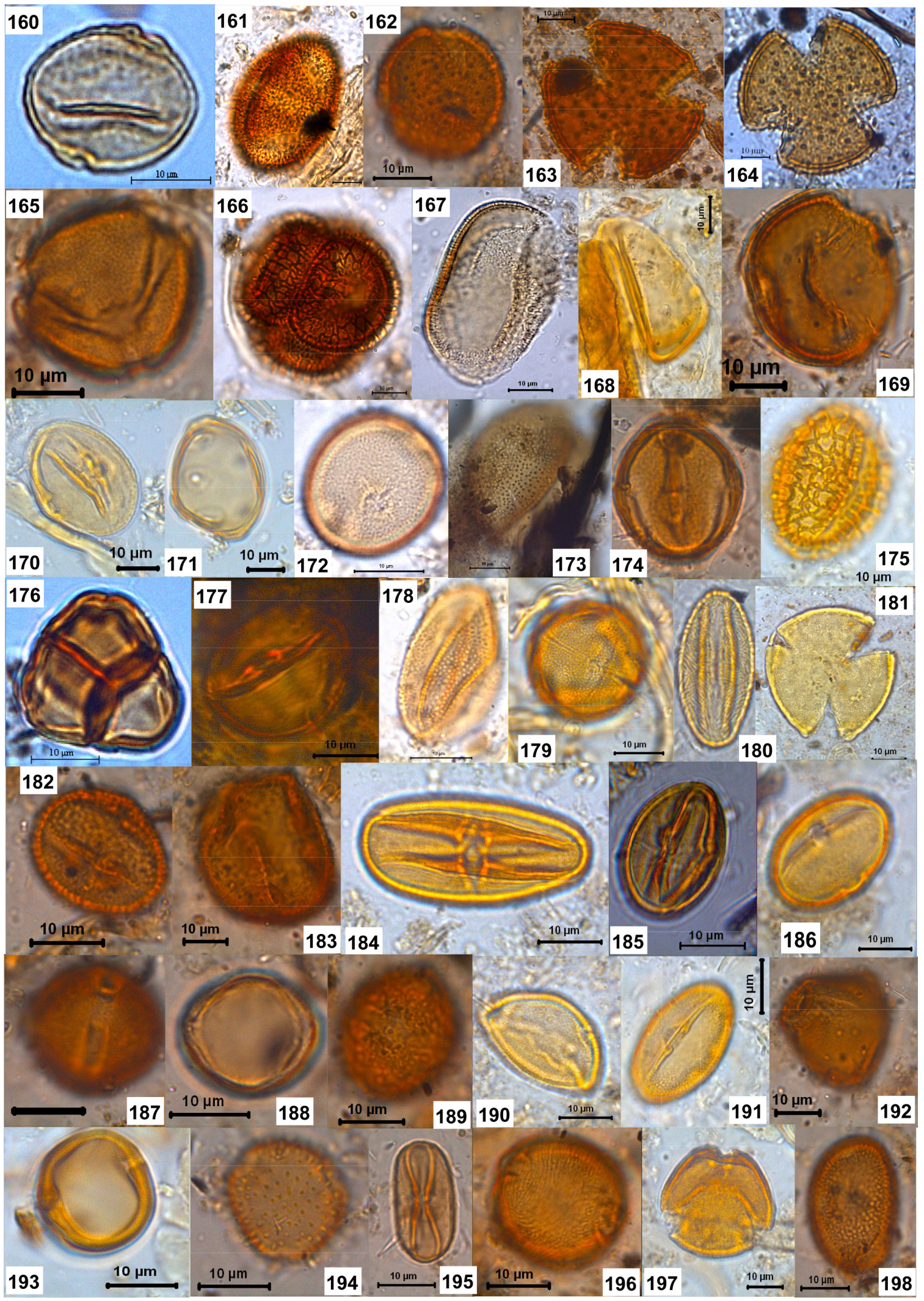




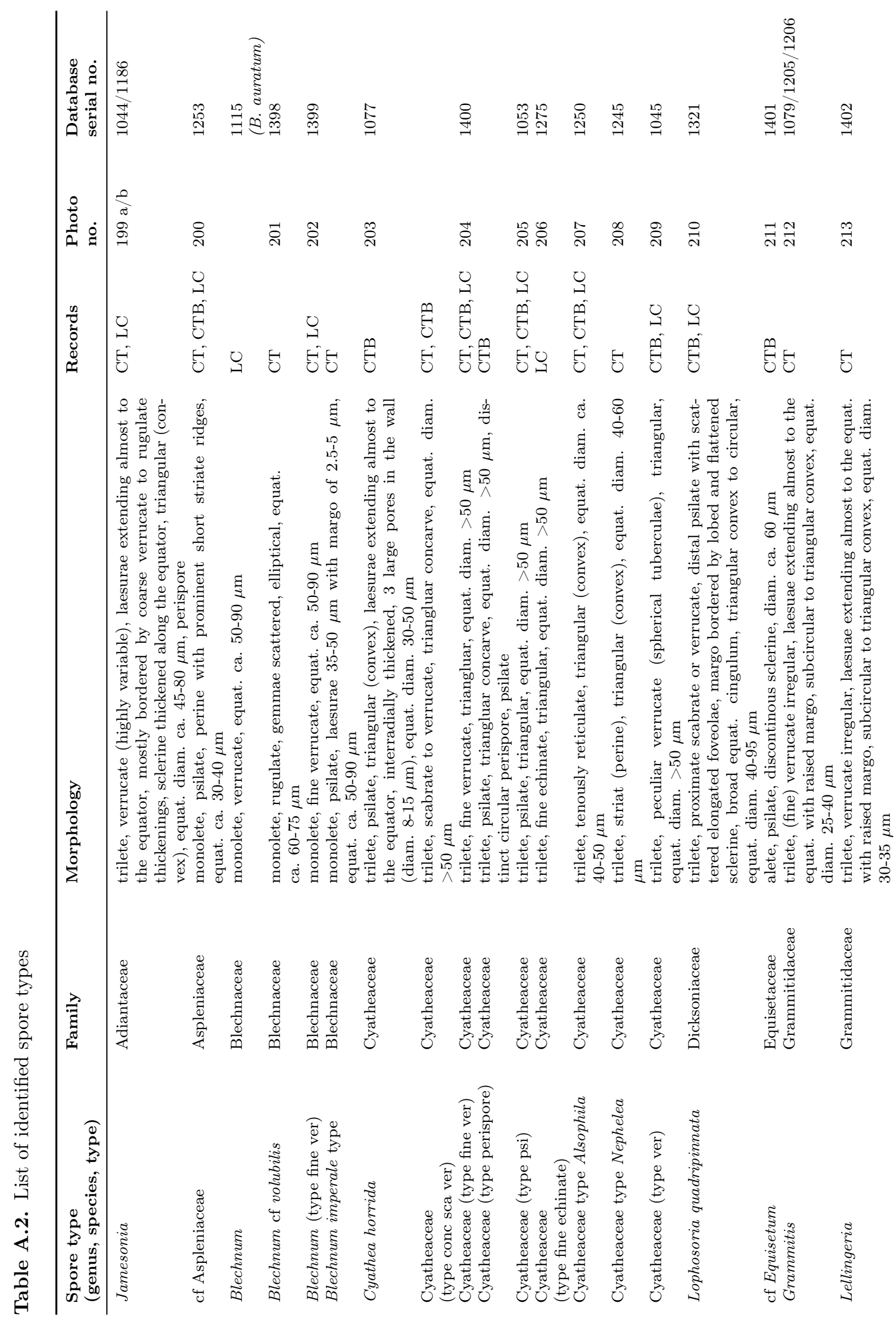




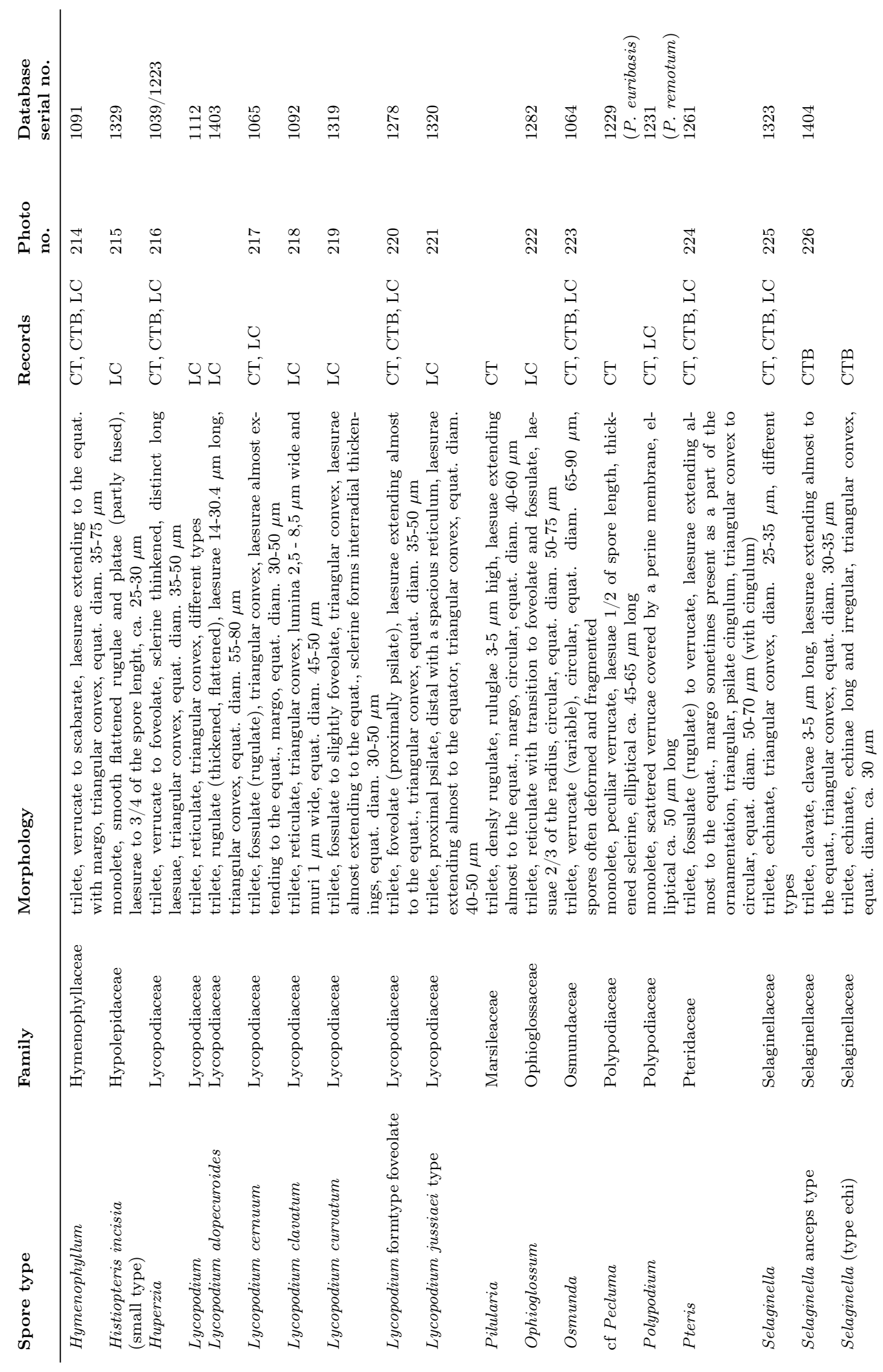




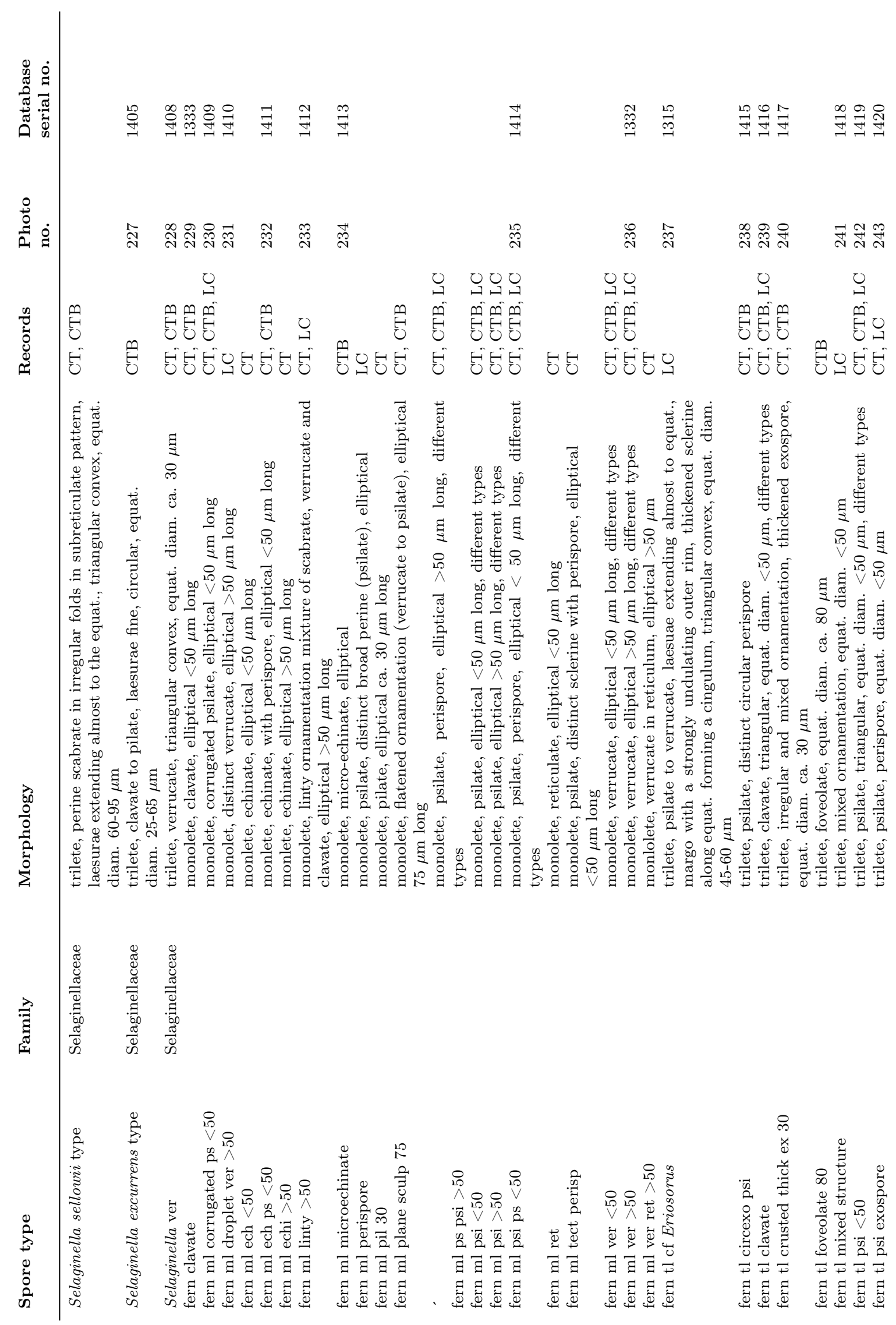




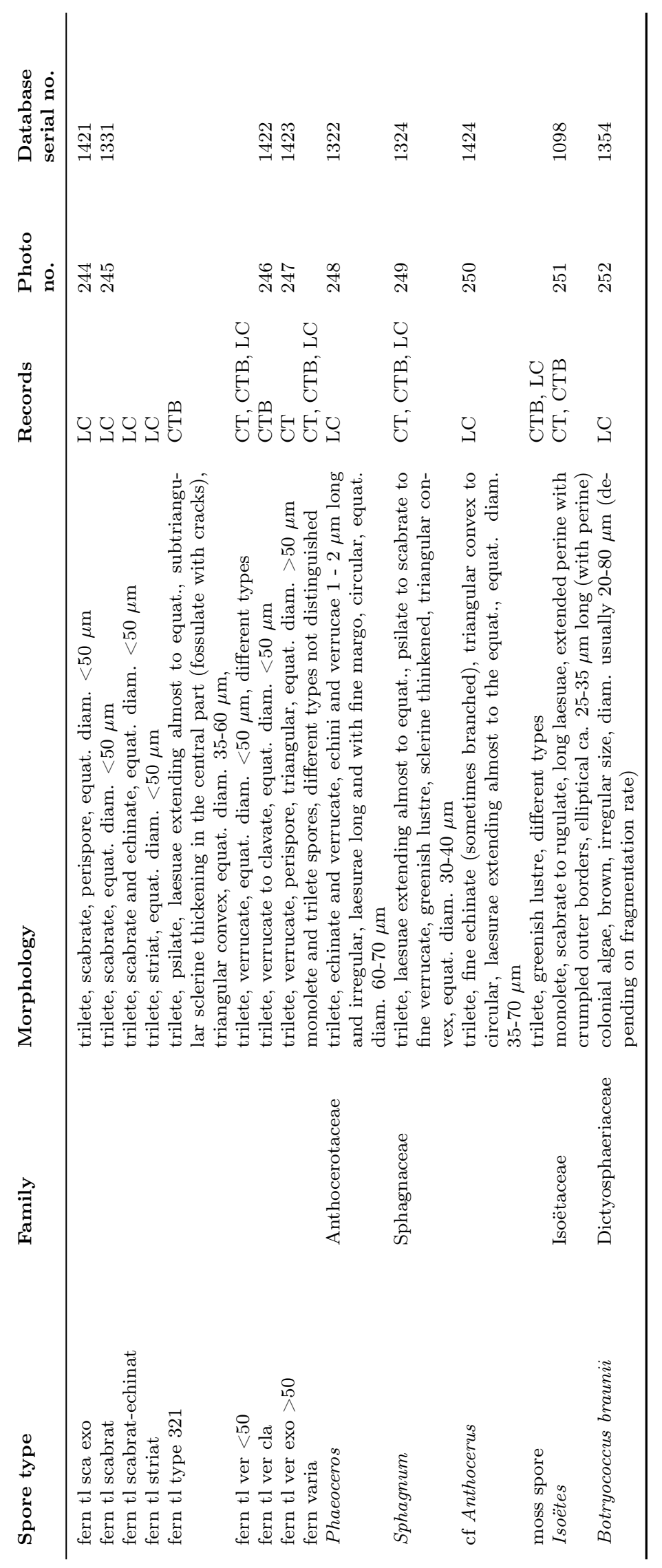


Spore plate 1

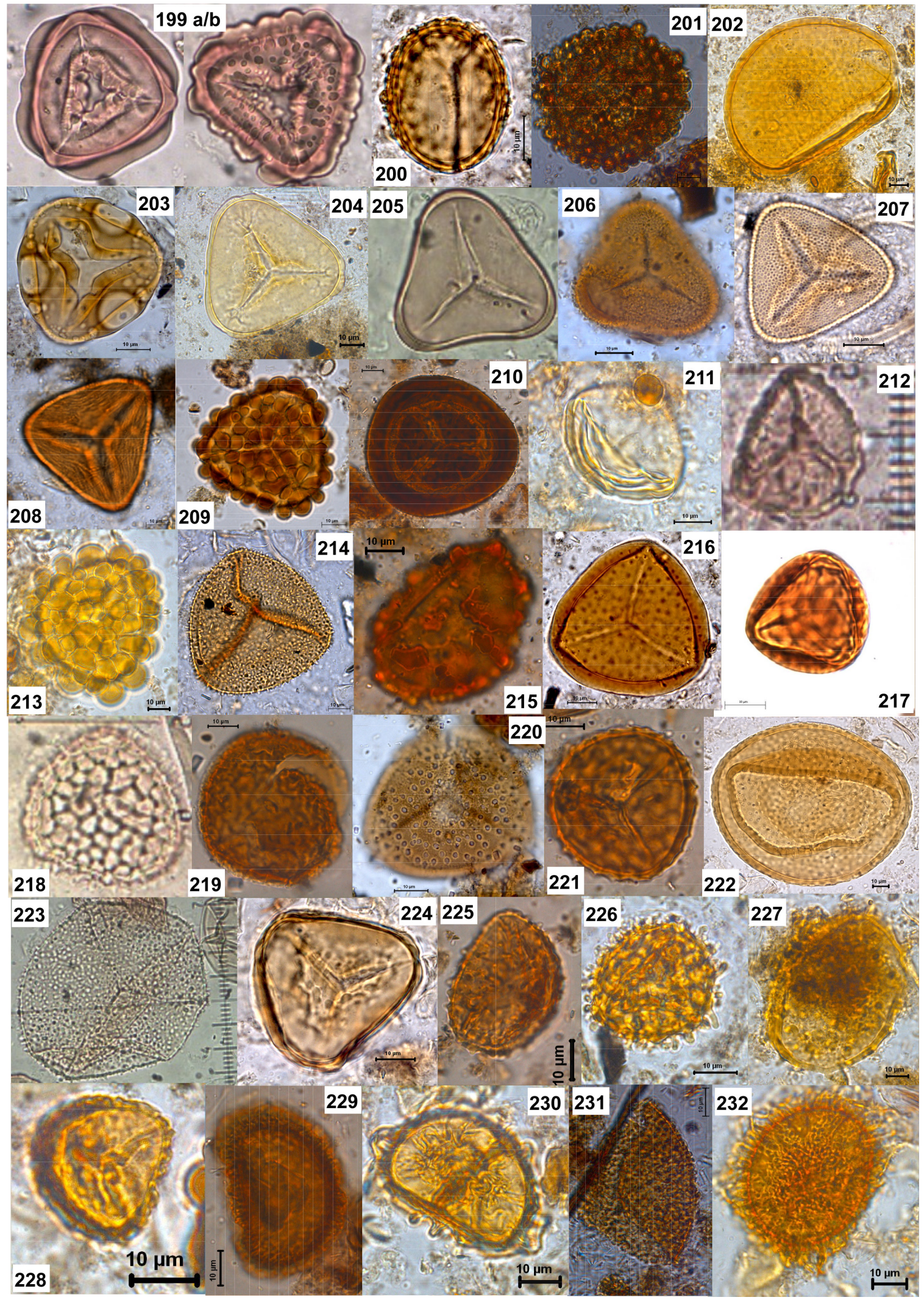


Spore plate 2

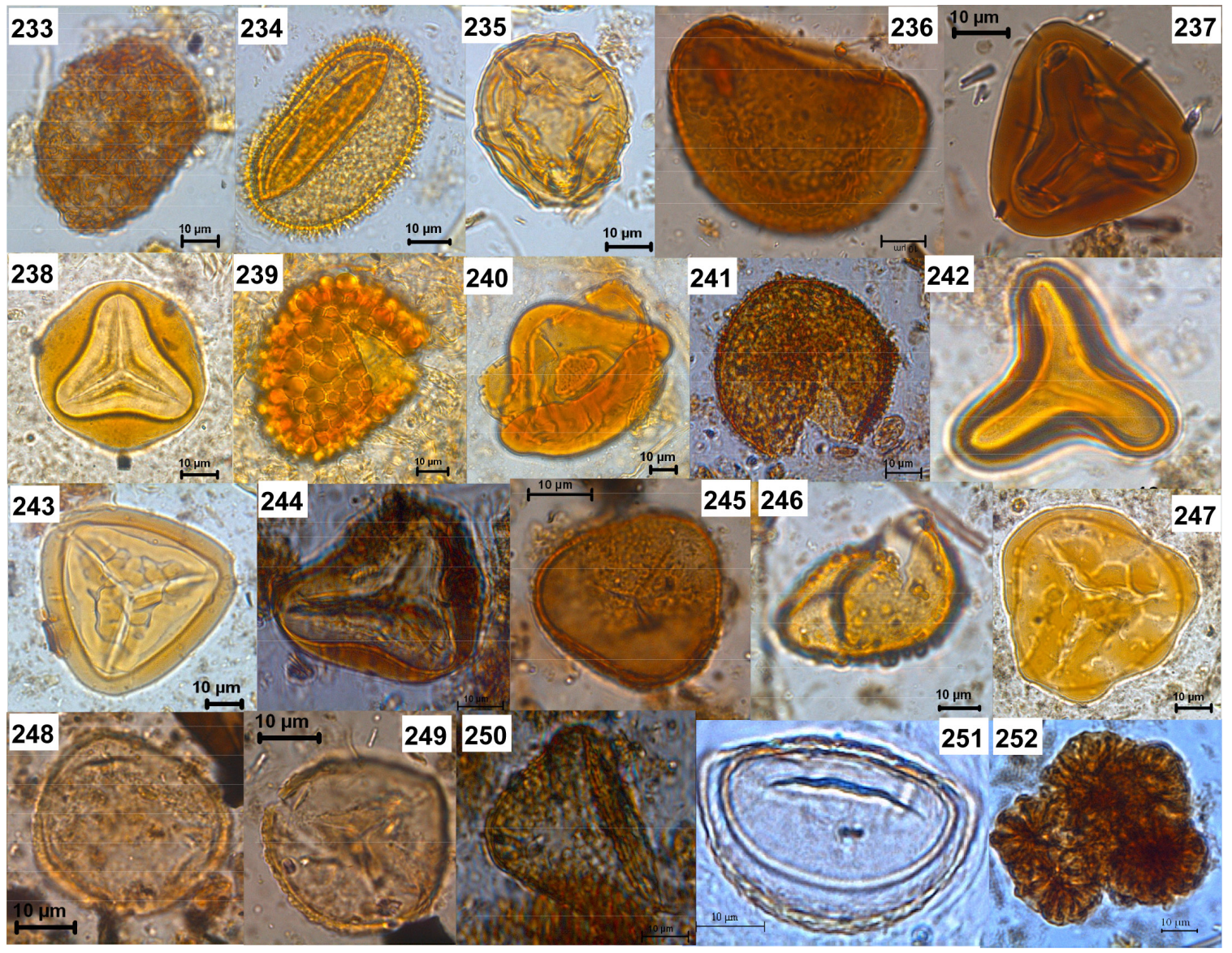


Appendix B.

Complete pollen records 


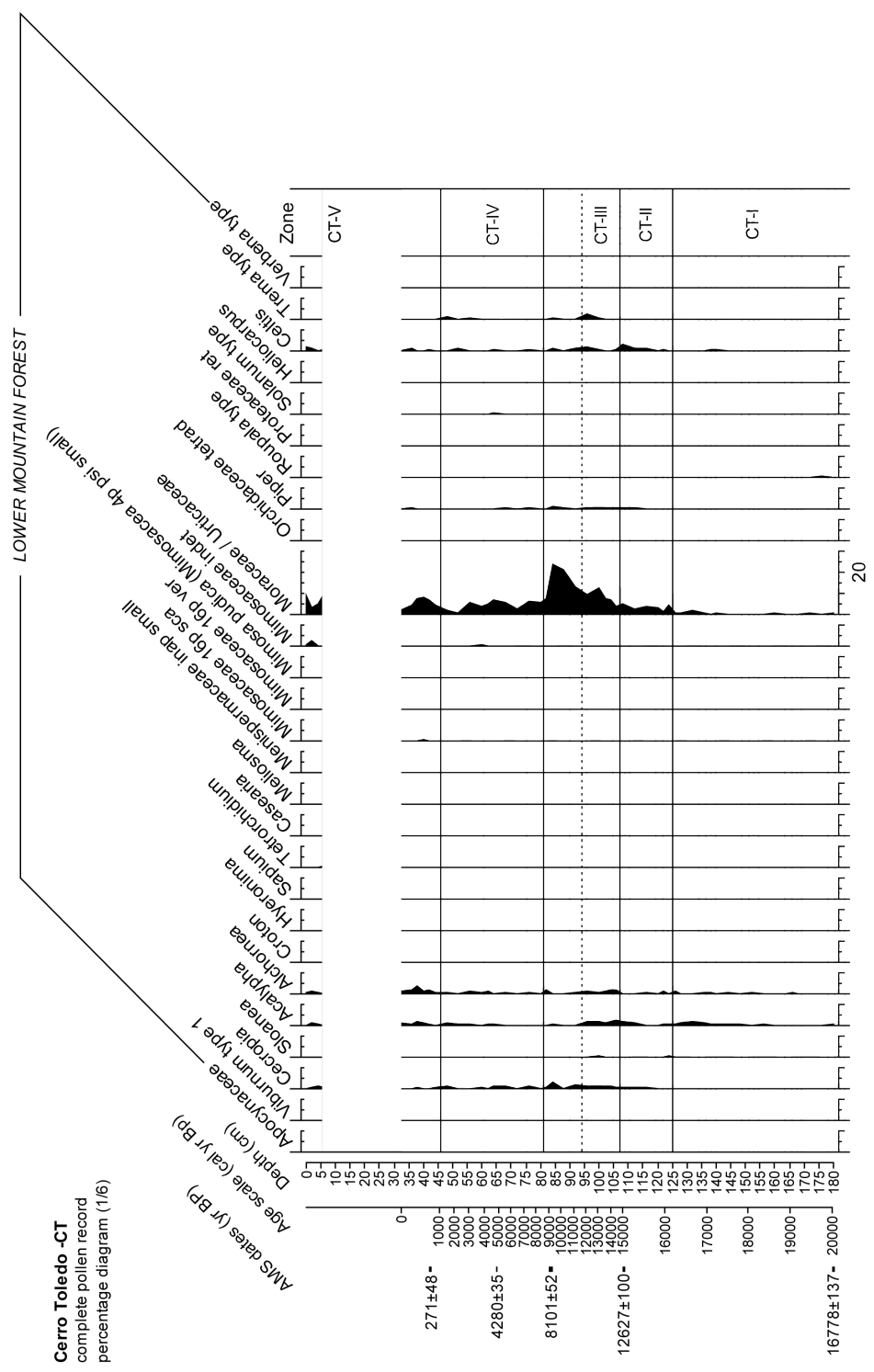




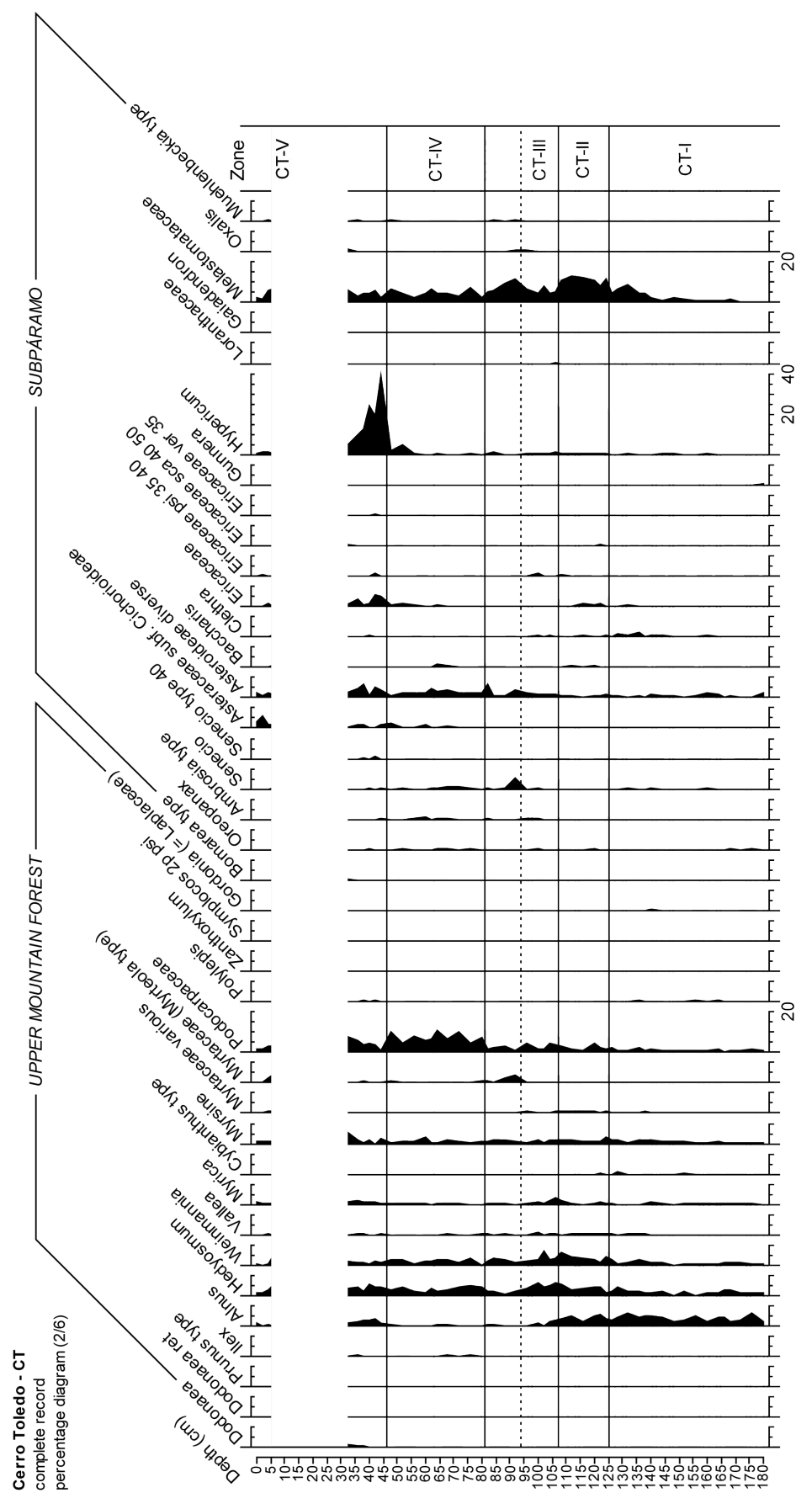




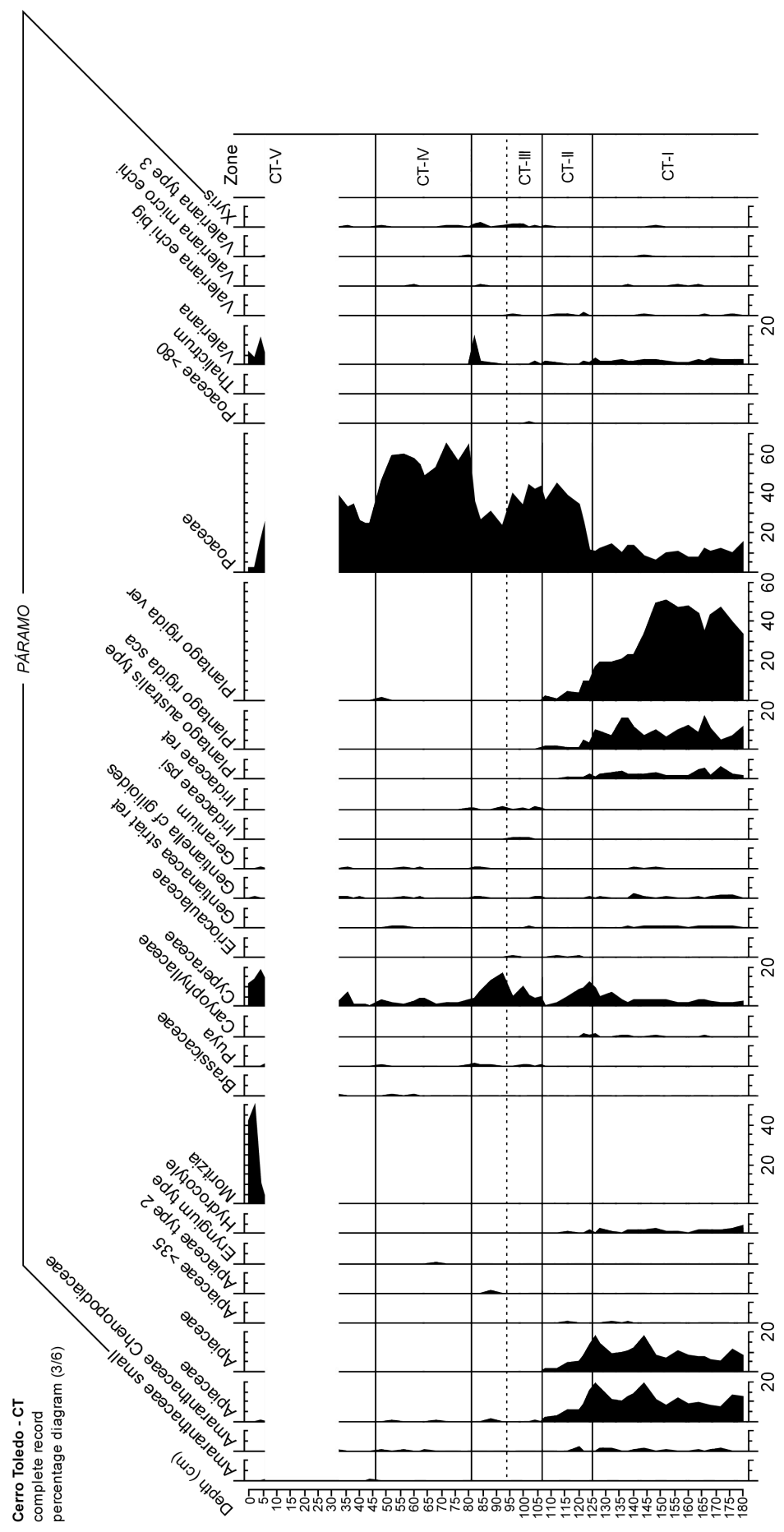




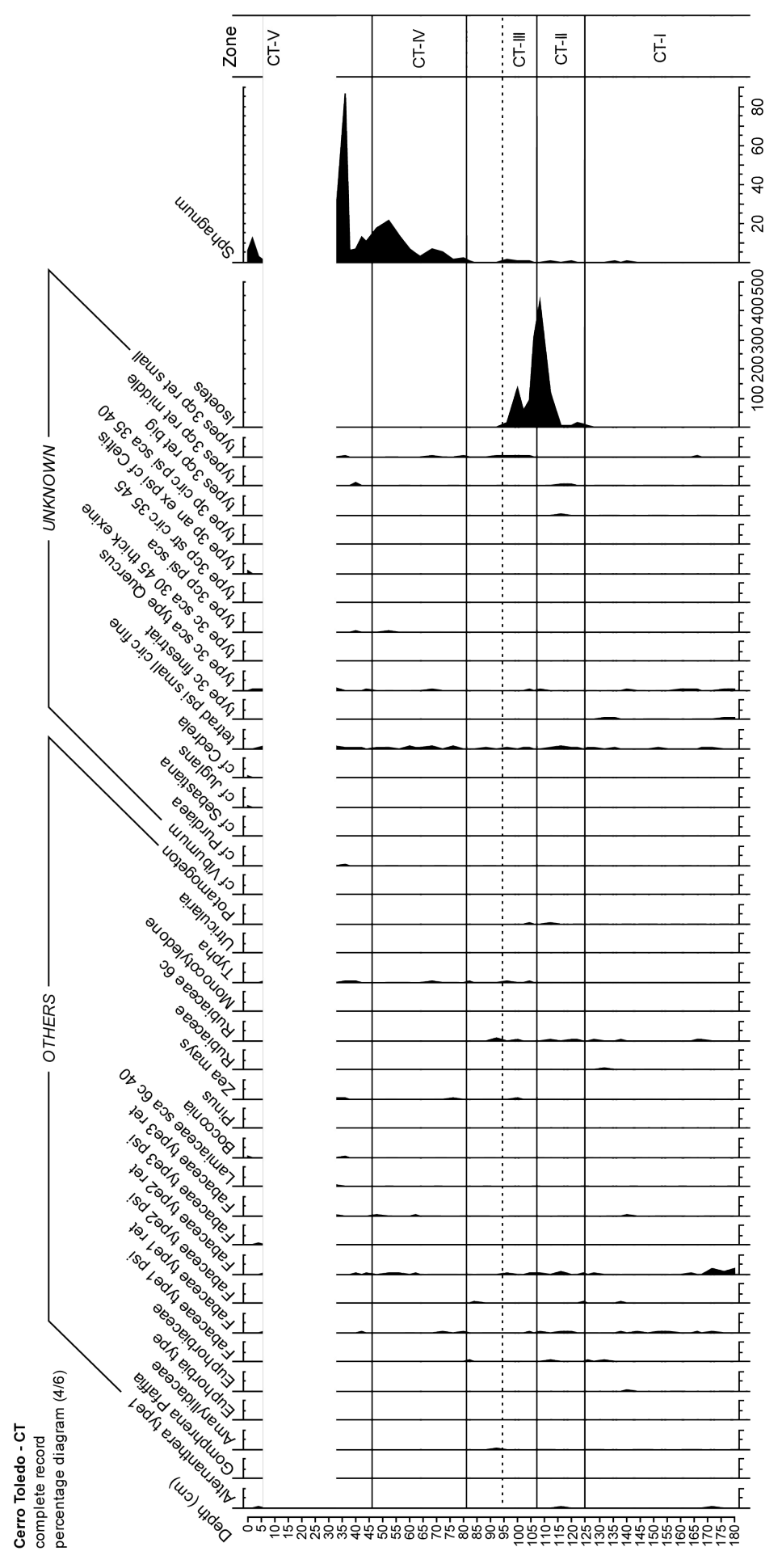




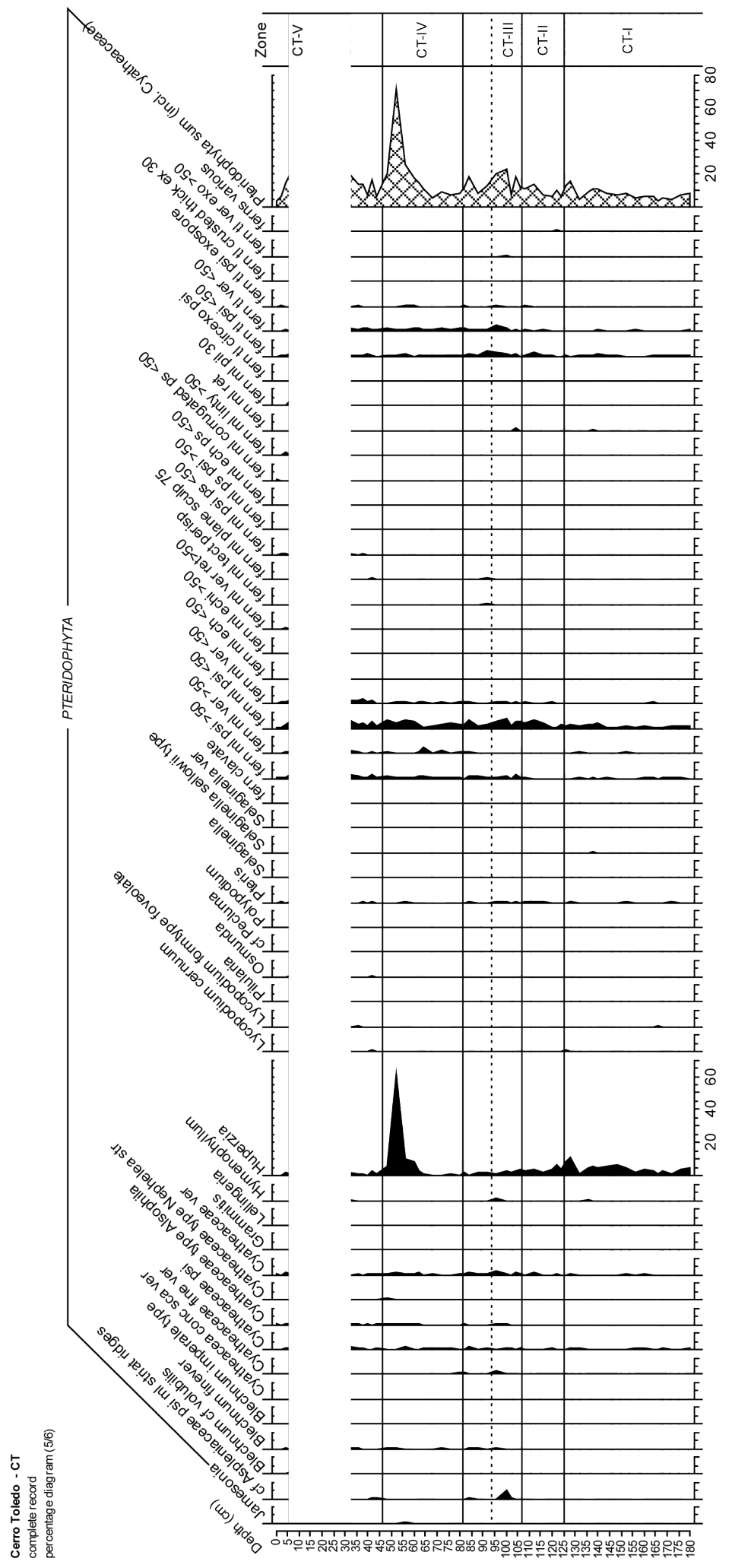




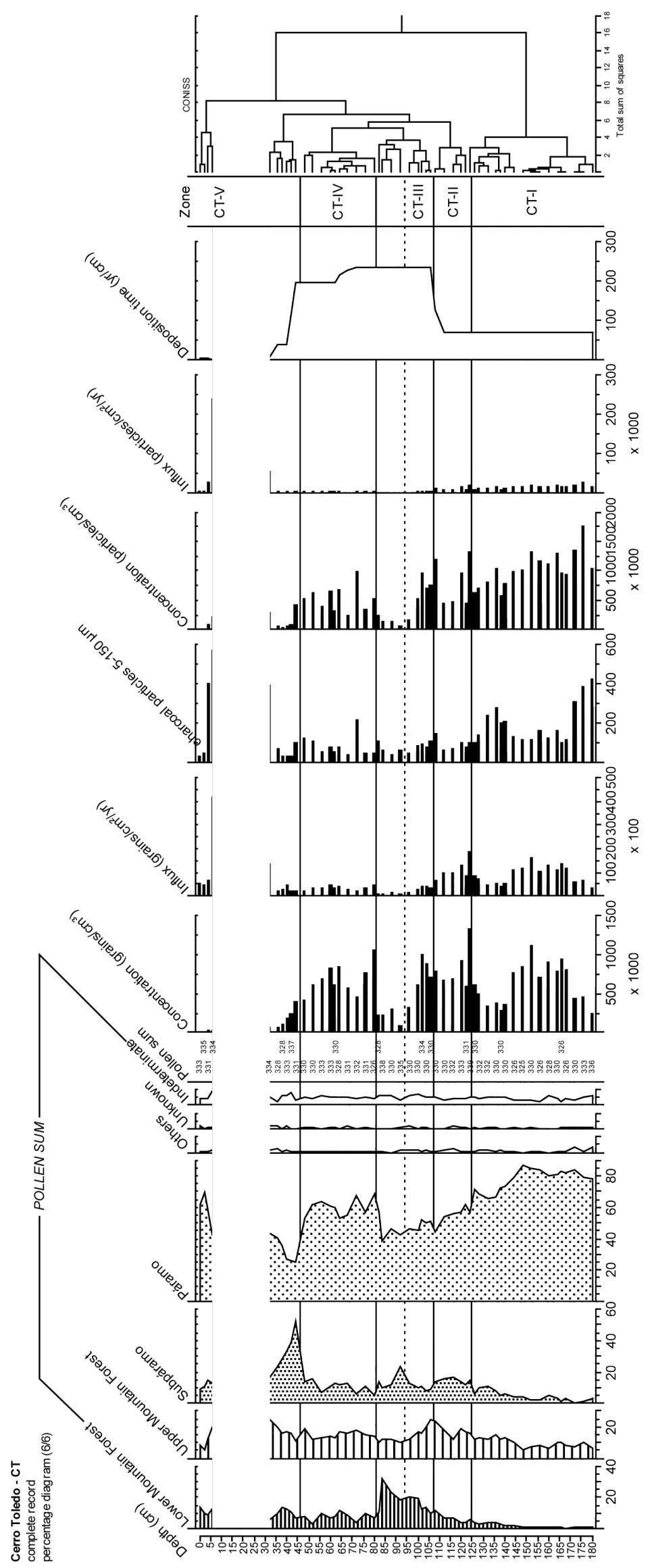




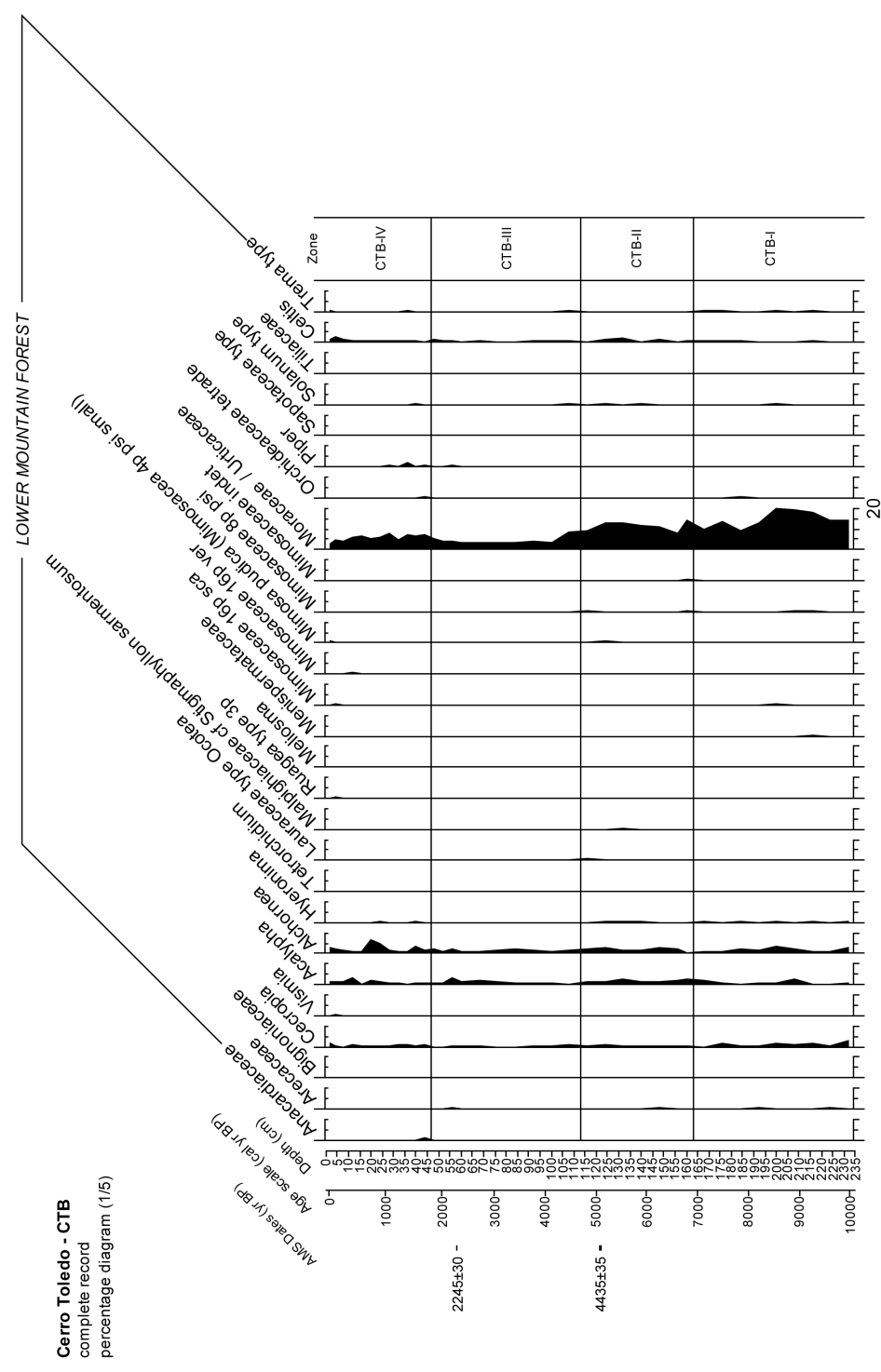




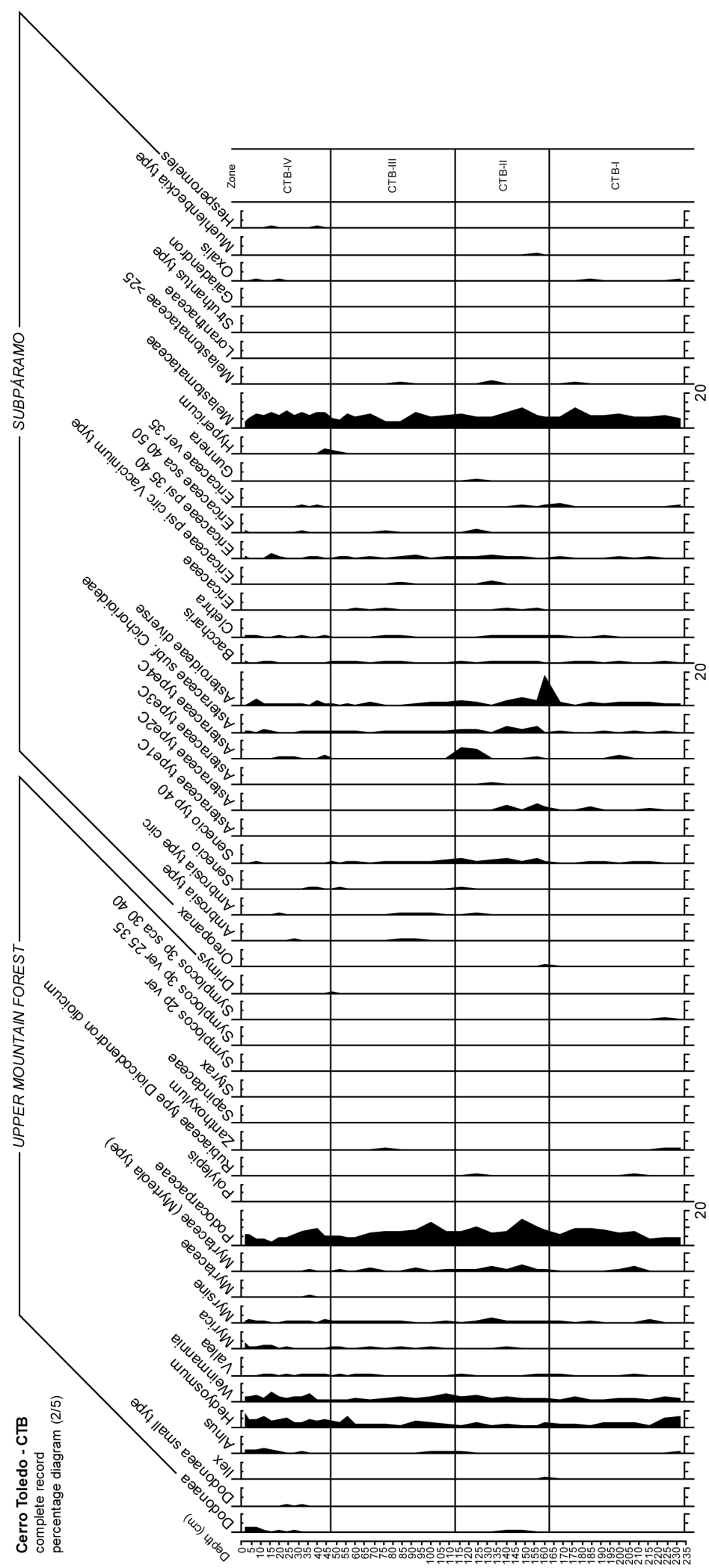




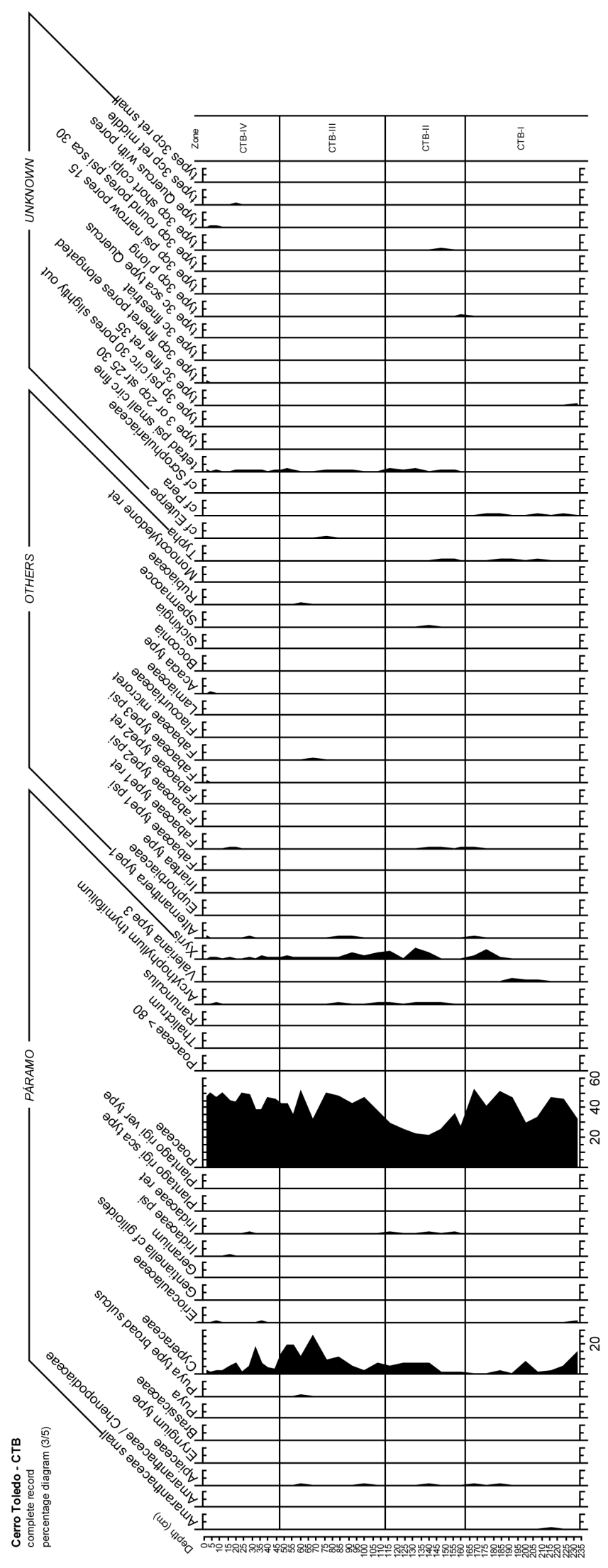




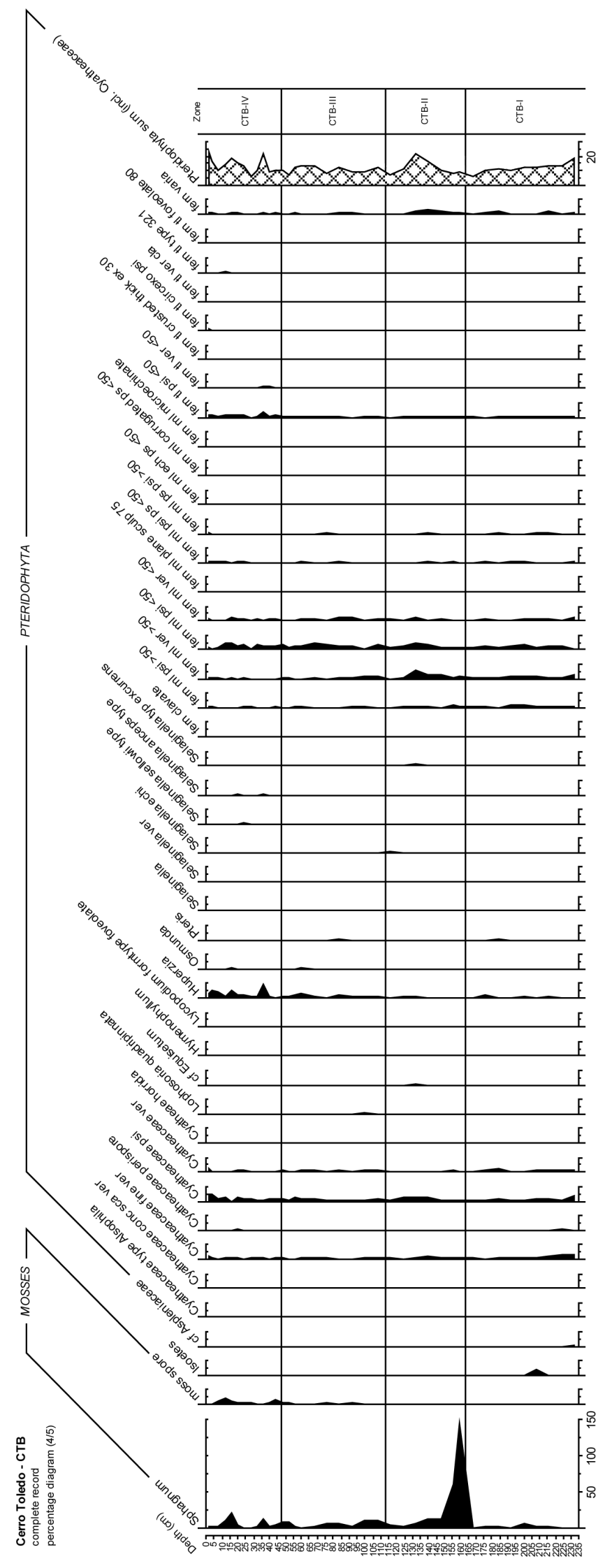




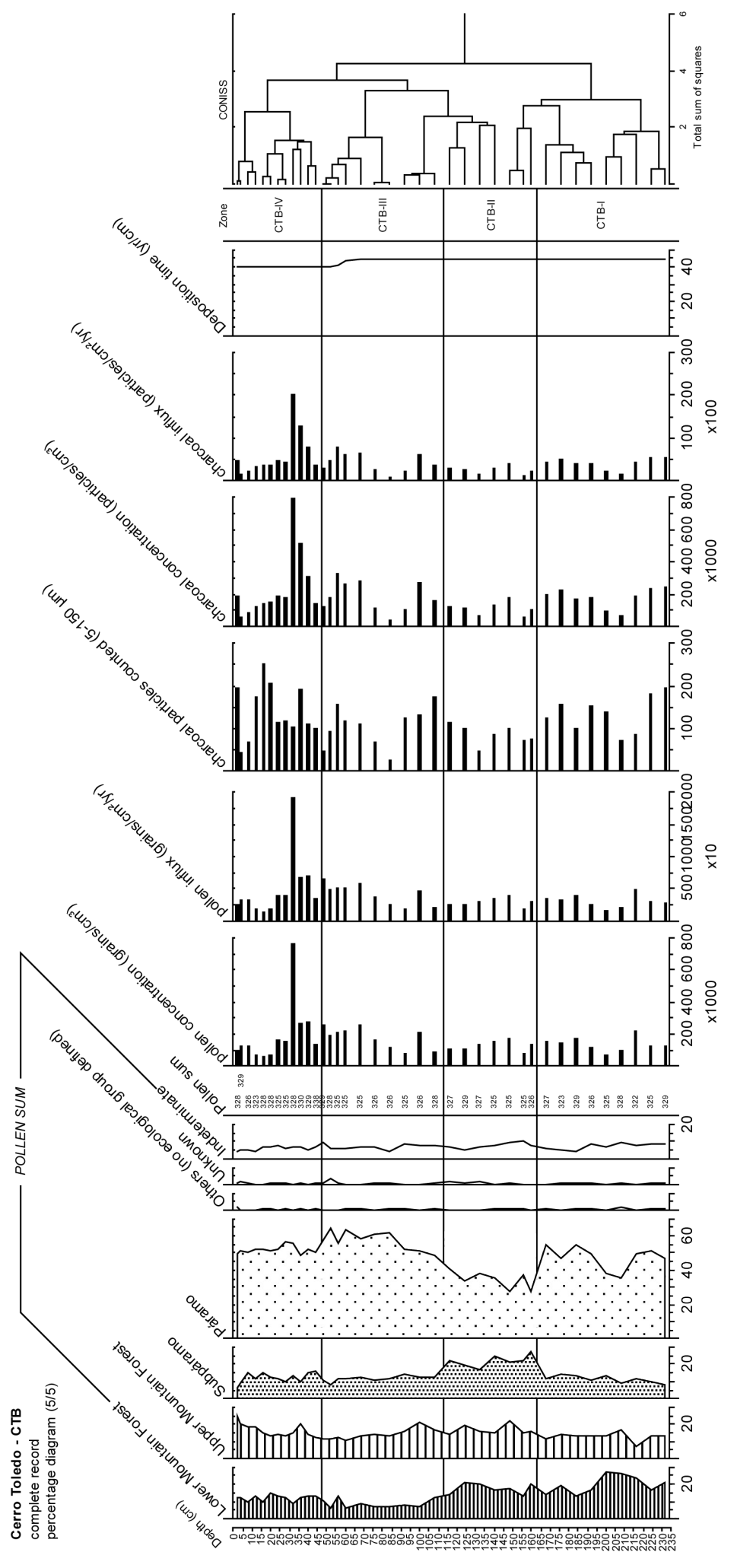


Appendix B. Complete pollen records

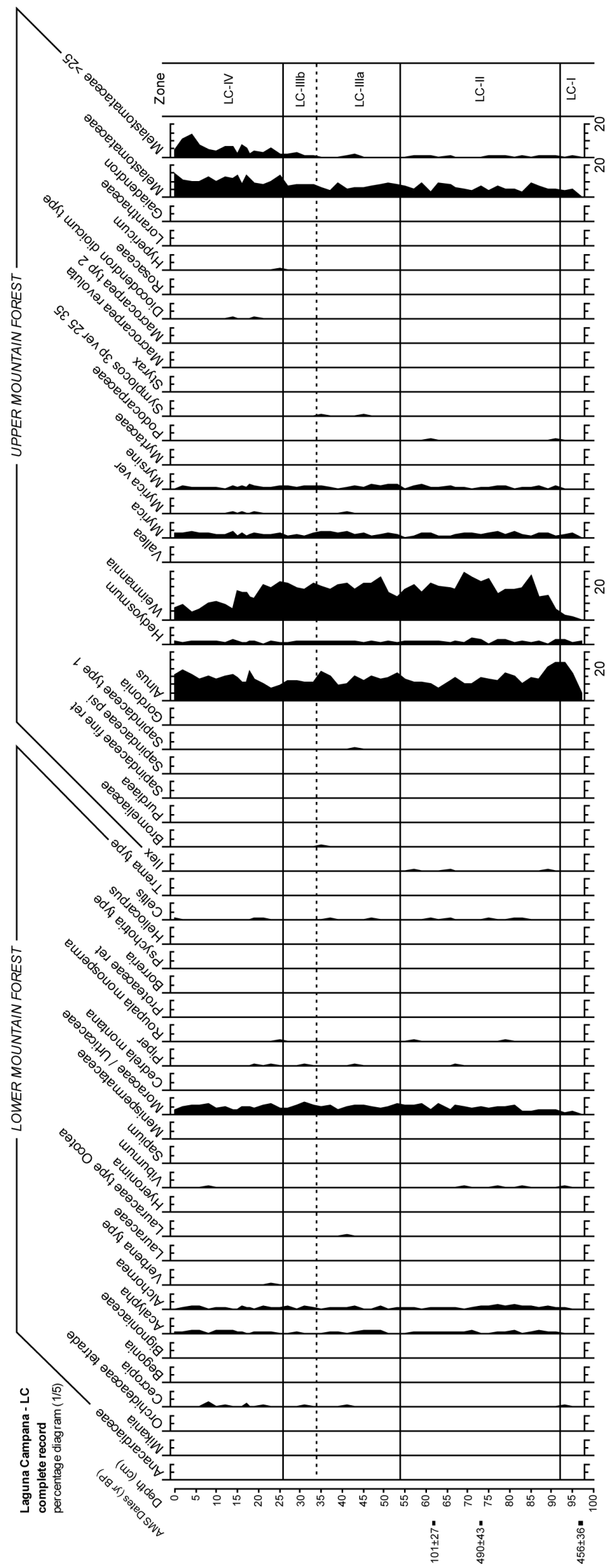




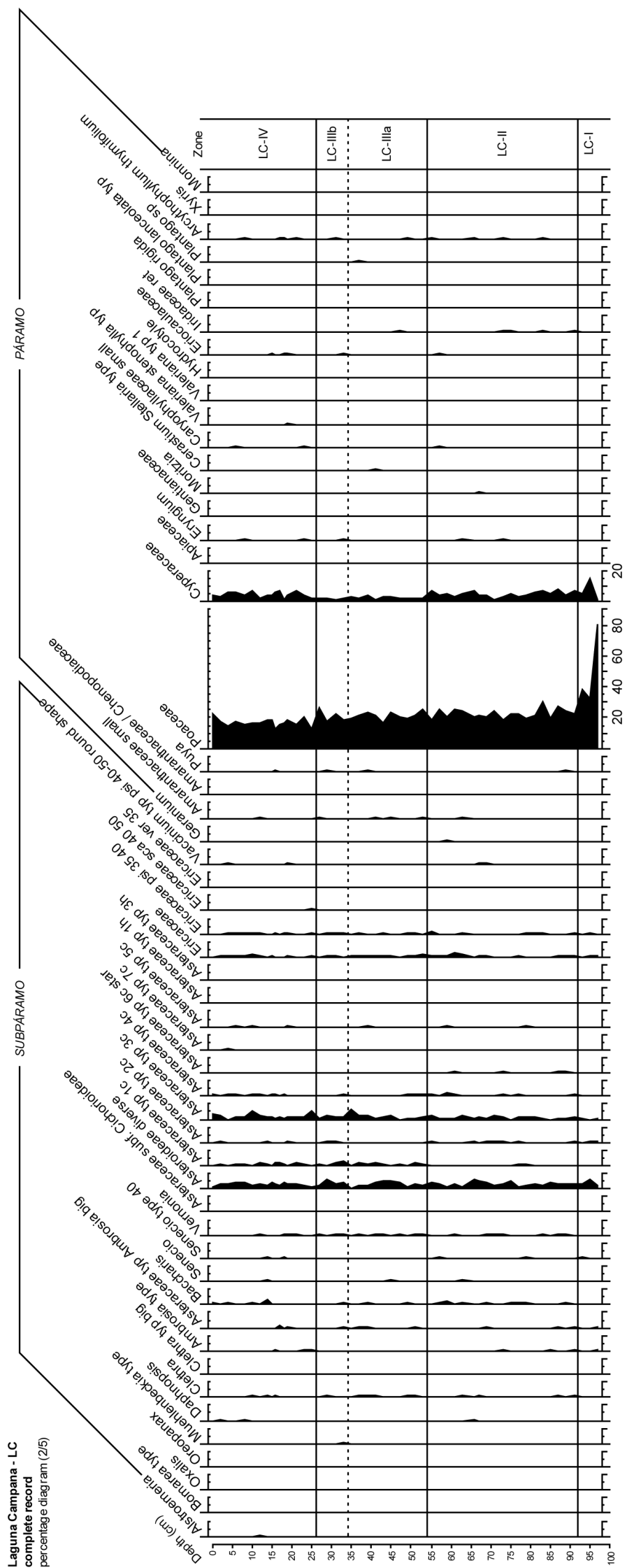




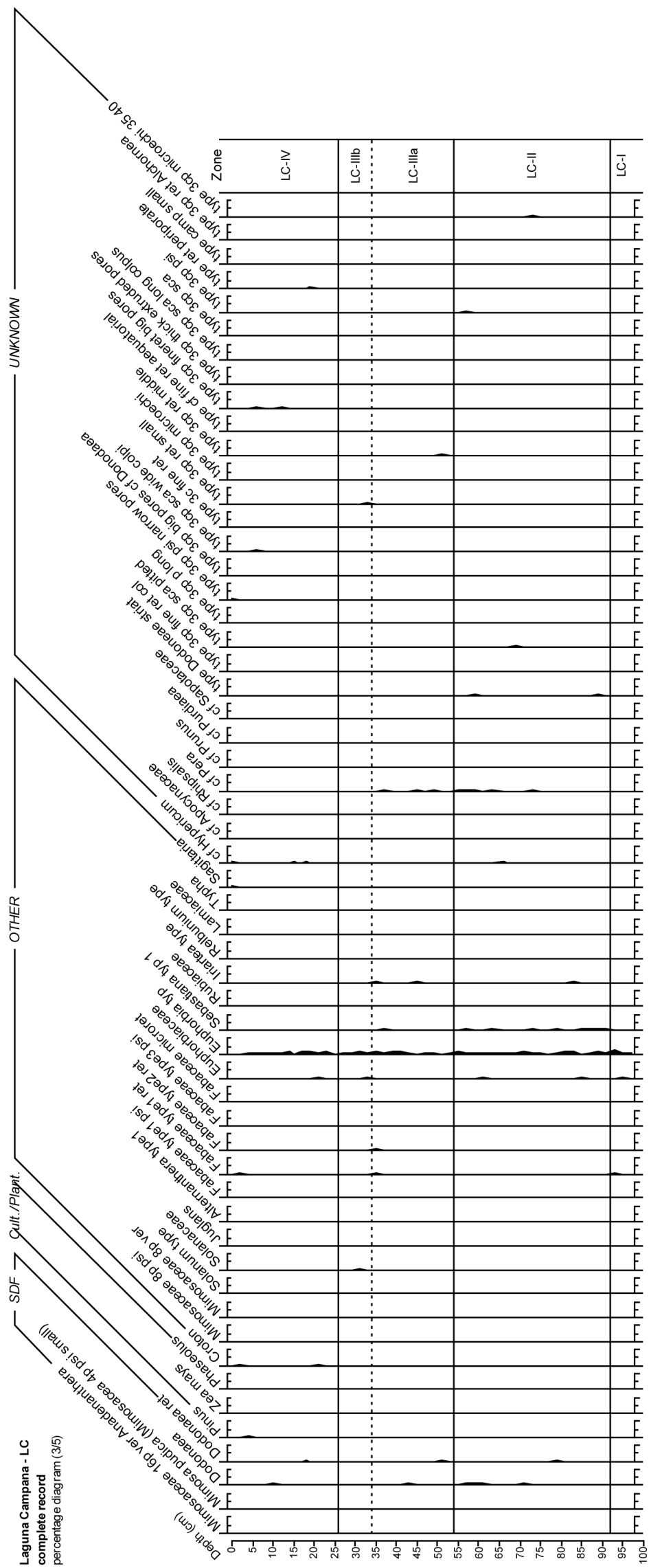




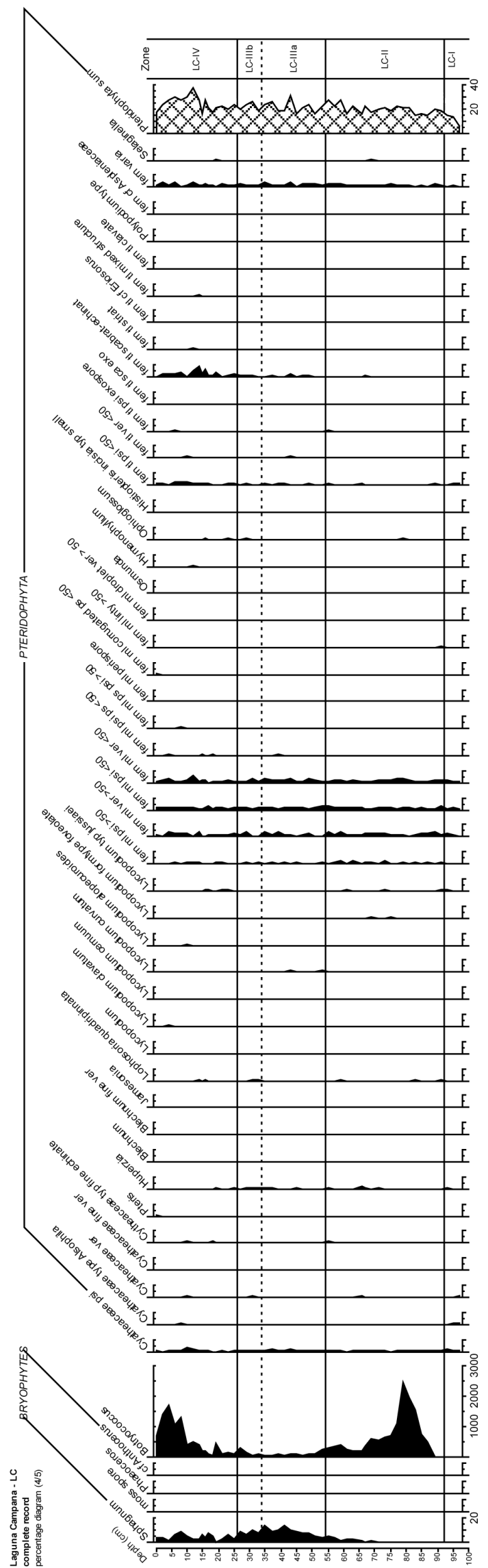




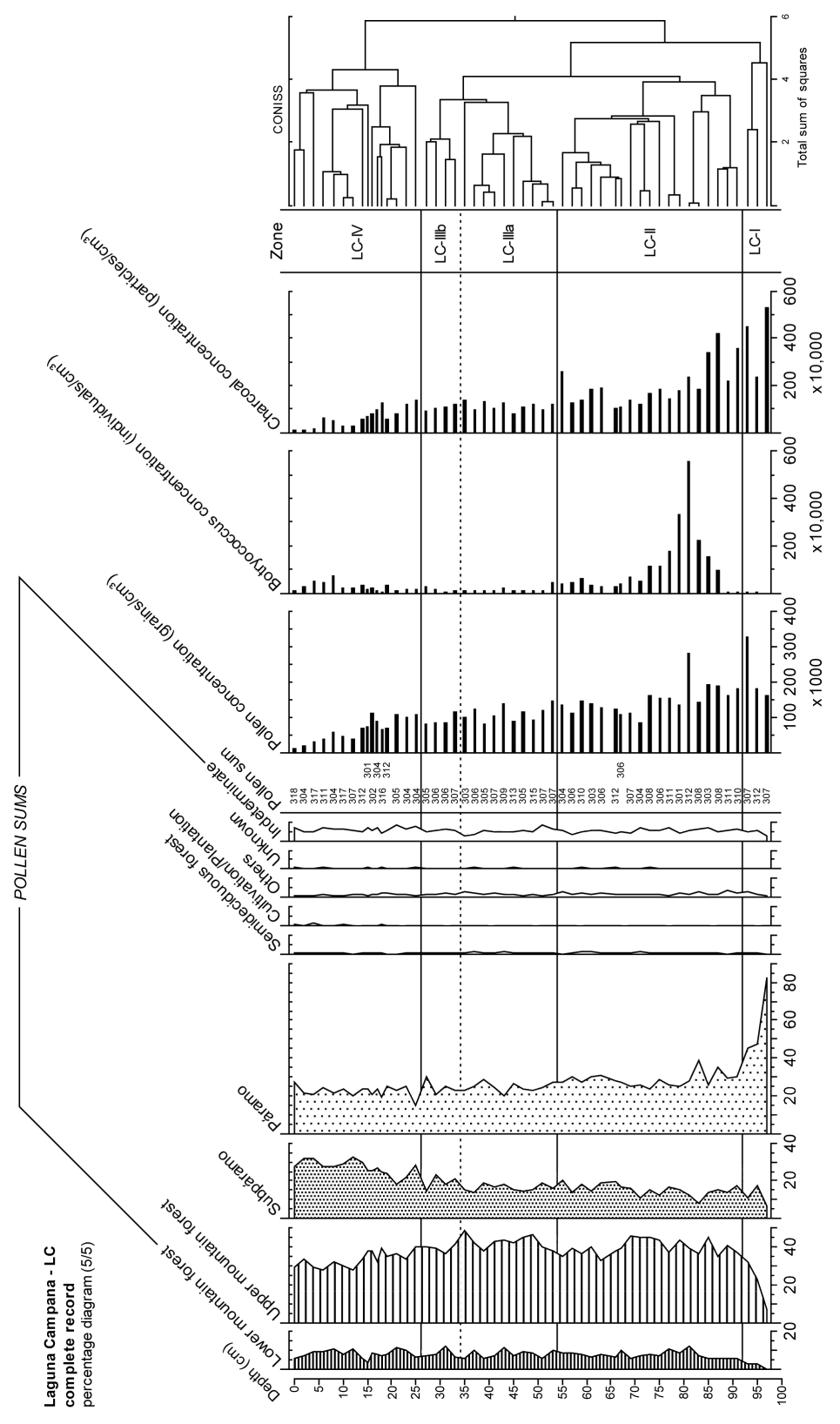




\section{CURRICULUM VITAE}

\section{PERSONAL DATA}

Name

Corinna Brunschön

Date of birth 31.10 .1979

Place of birth Hannover, Germany

Nationality German

\section{WORKING/ PRACTICAL EXPERIENCE}

2007-2010 | Scientific assistant at the Department of Palynology and Climate Dynamics, Albrecht-vonHaller Institute for Plant Sciences, University of Göttingen, Germany -DFG project: Reconstruction and modelling of late Quaternary and modern landscape dynamics in the PNP and neighbouring regions in Ecuador -Project organization, field work in Ecuador, palynological research, teaching assistance

2006-2007 Graduate assistant at the Department of Palynology and Climate Dynamics, Albrecht-vonHaller Institute for Plant Sciences, University of Göttingen, Germany

- Field assistance in Ecuador, palynological data analysis

2006 Intern at IFAW, Germany

- Campaigns assistance

2005-2006 Voluntary assistant at Tree Foundation, India

- Turtle conservation, community development

since 2005 Voluntary staffer "Digitaler Fischartenatlas von Deutschland und Österreich“ (www.fischartenatlas.de)

$2004 \quad$ Study-related internships at Rio Muchacho and EcoCiencia, Ecuador - Organic farming, ecological modeling (species distribution)

\section{EDUCATION}

2007-2010 PhD program (Biology) at the Department of Palynology and Climate Dynamics, Albrechtvon-Haller Institute for Plant Sciences, University of Göttingen, Germany

2001-2005 Study of "International Degree Course Industrial and Environmental Biology“, Hochschule Bremen - University of applied sciences, Germany

Degree: Dipl. Umweltbiol. (FH)

1996-1999 Gymnasium Großburgwedel, High school graduation (Abitur)

1992-1996 Realschule Burgwedel,

Advanced secondary school graduation (Erweiterter Sekundarabschluss I) 